\title{
Characterisation of organic cereals and grain legumes as feedstuffs for monogastric animals: Effects of variety and environmental conditions on the contents of crude nutrients, amino acids, thiamine, riboflavin, and in vitro digestibility of crude protein and amino acids
}

\author{
Charakterisierung von Öko-Getreide und -Körnerleguminosen \\ als Futtermittel für Monogastrier:
}

Einfluss von Sorte und Umwelt auf die Gehalte an Rohnährstoffen, Aminosäuren, Thiamin, Riboflavin und in vitro Rohprotein- und Aminosäurenverdaulichkeit

\begin{abstract}
Dissertation
zur Erlangung des Doktorgrades

an der Fakultät für Agrarwissenschaften

der Georg-August-Universität Göttingen
\end{abstract}

Vorgelegt von

Stephanie Witten

23.04.1987, Hamburg 
D 7

1. Referent: Prof. Dr. Frank Liebert

2. Referent: Dr. Karen Aulrich

3. Referent: Prof. Dr. Elke Pawelzik

Tag der mündlichen Prüfung: $\quad$ 05.11.2018 


\section{Cheinem Grofvater}

" Feed evaluation in its practical sense is and always will be a compromise between the need for

simplicity, speed and low cost on the one hand, and the great complexity of feedstuffs and of the living organisms on the other."

Eow (1990) 


\section{Part of this work is published in peer-reviewed journals:}

Witten S., Aulrich K. (2018). Effect of variety and environment on the amount of thiamine and riboflavin in cereals and grain legumes. Anim Feed Sci Tech 238, 39-42.

DOI: 10.1016/j.anifeedsci.2018.01.022

Witten S., Aulrich K. (2018). Exemplary calculations of native thiamine (vitamin $B_{1}$ ) and riboflavin (vitamin $\mathrm{B}_{2}$ ) contents in common cereal-based diets for monogastric animals. Org Agr, online first.

DOI: $10.1007 / \mathrm{s} 13165-018-0219-9$

Witten S., Grashorn M., Aulrich K. (2018). Short Communication: Precaecal digestibility of crude protein and amino acids of a field bean (Vicia faba L.) and a field pea (Pisum sativum L.) variety for broilers. Anim Feed Sci Tech 243, 35-40.

DOI: 10.1016/j.anifeedsci.2018.07.001

Gefördert durch:
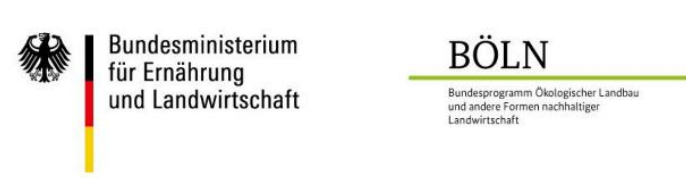

aufgrund eines Beschlusses des Deutschen Bundestages
The project was supported by funds of the Federal Ministry of Food and Agriculture (BMEL) based on a decision of the parliament of the Federal Republic of Germany via the Federal Office for Agriculture and Food (BLE) under the Federal Programme for Ecological Farming and Other Forms of Sustainable Agriculture (BÖLN 28110E054). 


\section{List of Contents}

\section{List of Abbreviations}

List of Tables

List of Figures

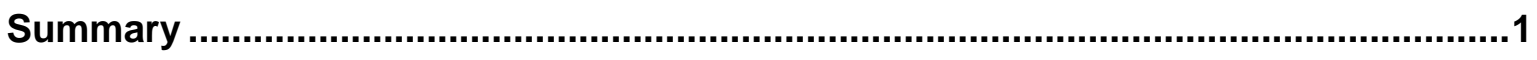

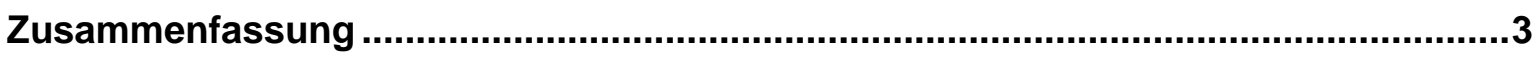

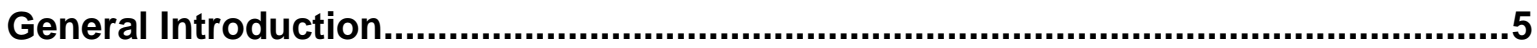

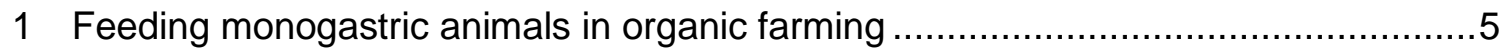

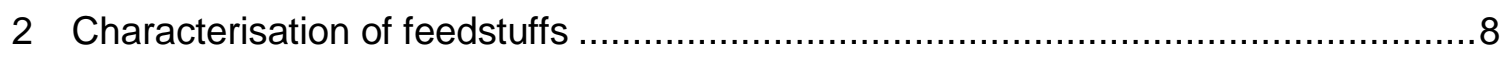

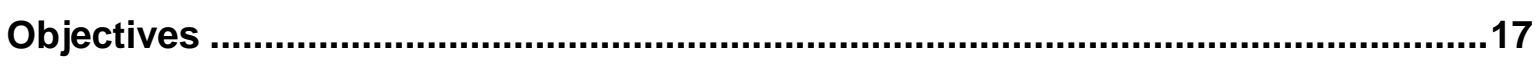

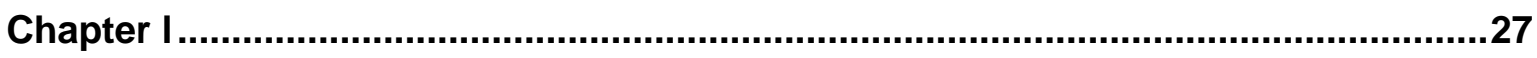

Effect of variety and environment on the contents of crude nutrients and amino acids in organically produced cereal and legume grains

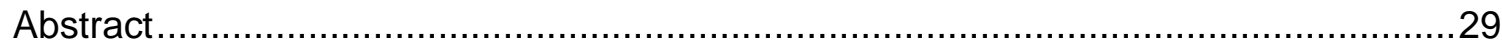

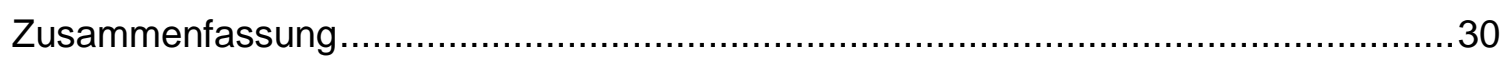

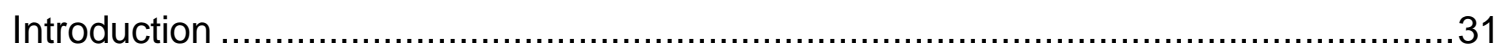

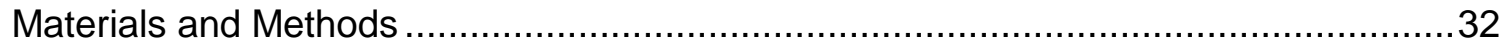

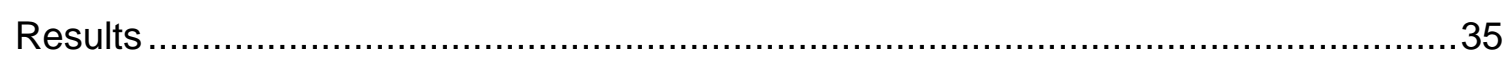

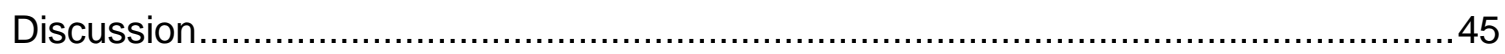

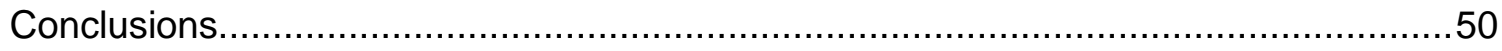

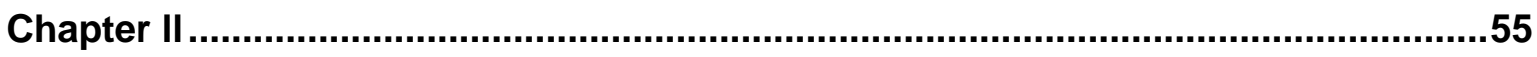

Precaecal digestibility of crude protein and amino acids of a field bean (Vicia faba L.) and a field pea (Pisum sativum L.) variety for broilers

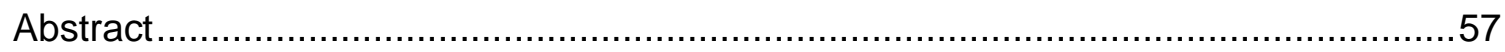

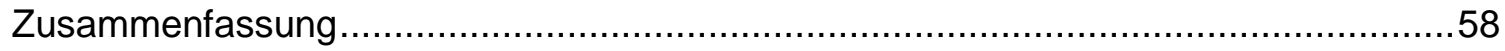

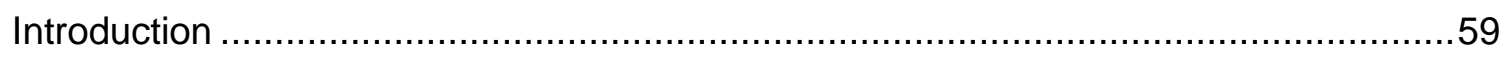

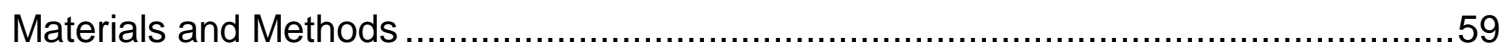

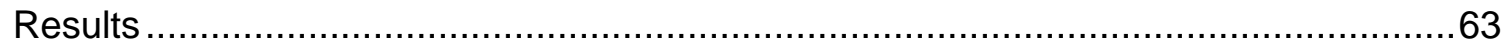

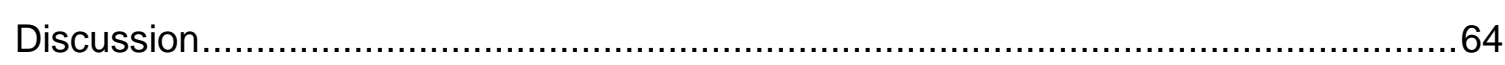

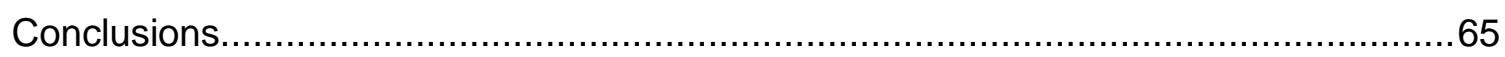

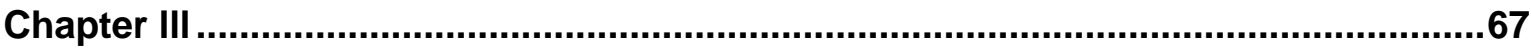

In vitro multi-enzyme approach to determine crude protein and amino acid digestibility of cereals and grain legumes in broiler chicken

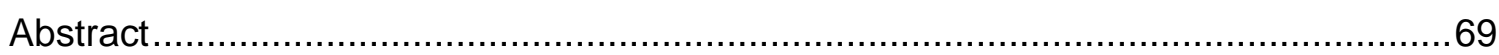

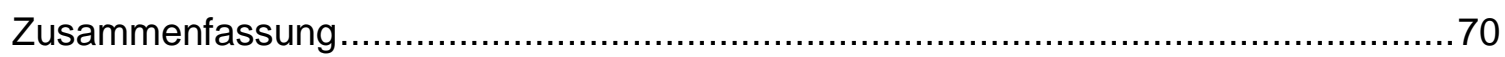

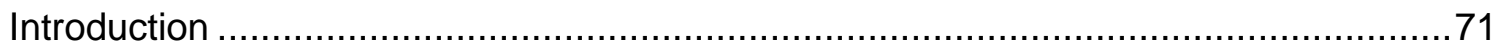

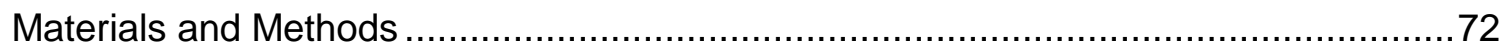

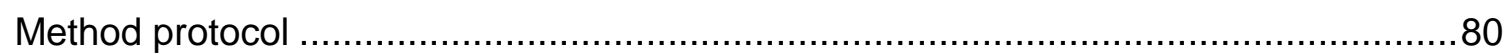




\section{Chapter IV}

Effect of variety and environmental conditions on in vitro crude protein and amino acid digestibility of cereals and grain legumes for broiler chicken

Abstract 89

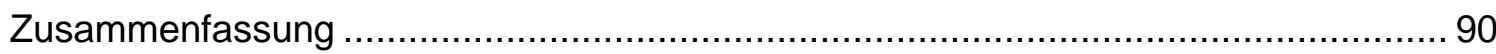

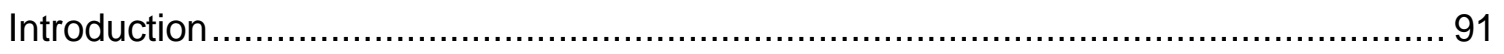

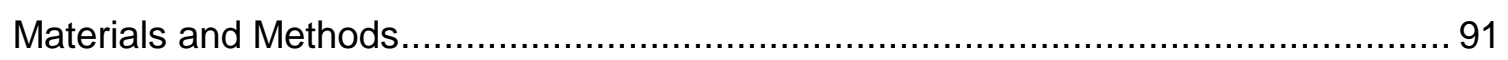

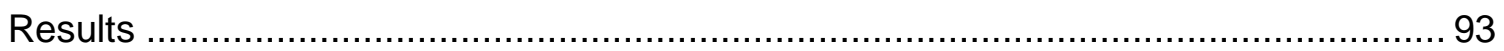

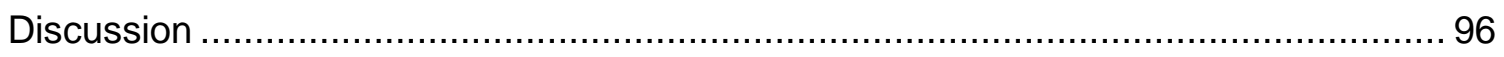

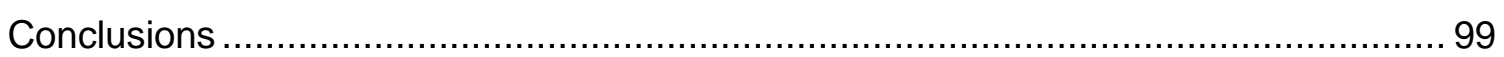

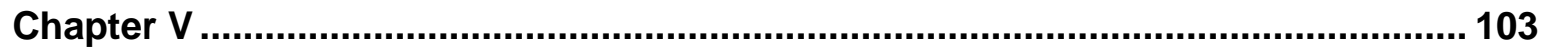

Effect of variety and environment on the amount of thiamine and riboflavin in cereals and grain legumes

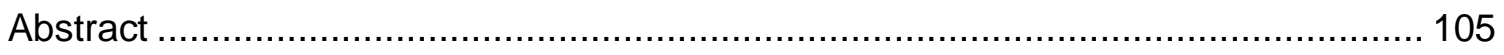

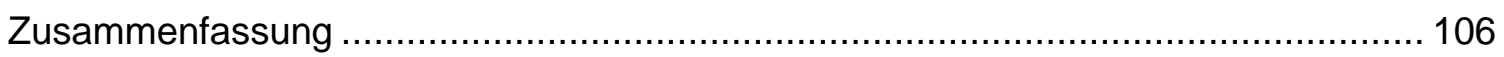

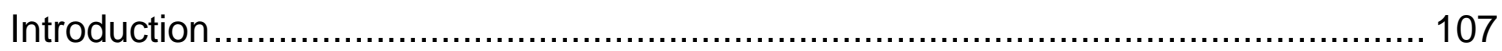

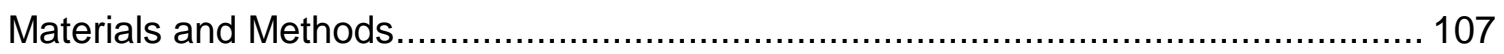

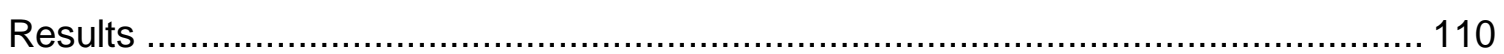

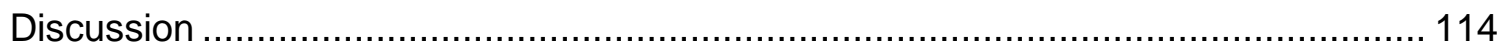

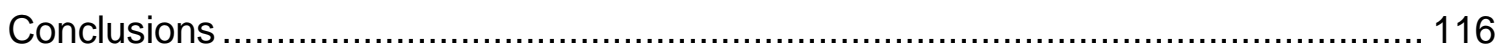

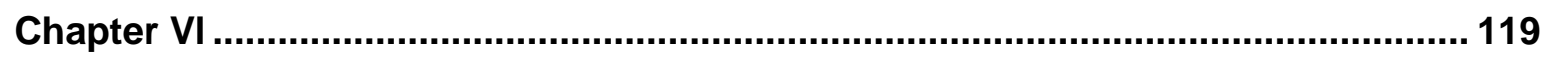

Exemplary calculations of native thiamine (vitamin $B_{1}$ ) and riboflavin (vitamin $B_{2}$ ) contents in common cereal-based diets for monogastric animals

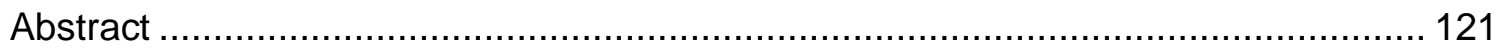

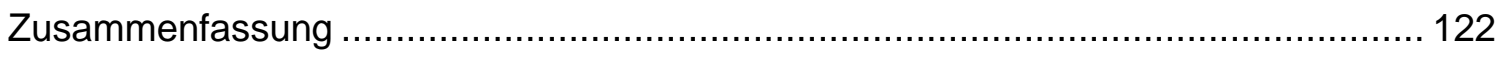

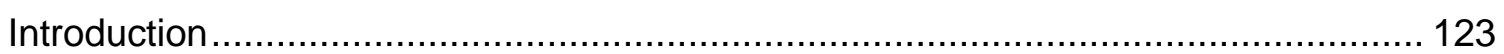

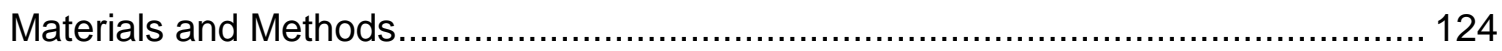

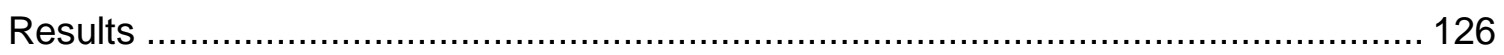

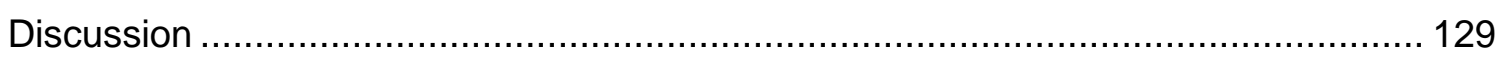

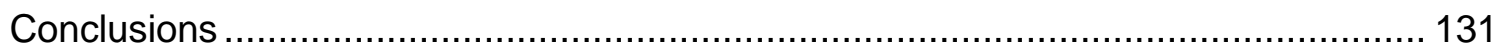

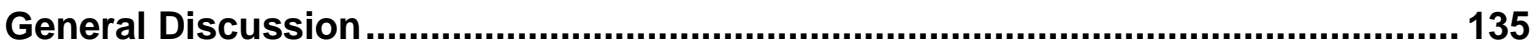

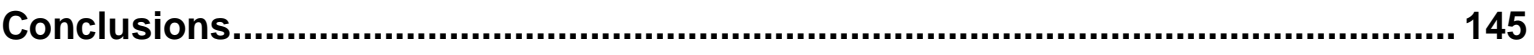

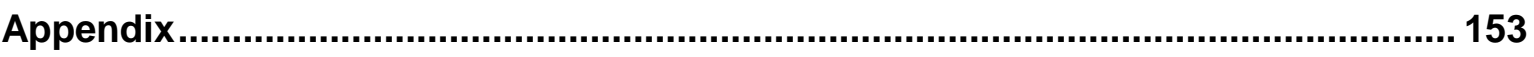

Declaration of Academic Integrity

Danksagung/Acknowledgement 


\section{List of Abbreviations}

Following abbreviations are used in addition to the abbreviations of the common international CGS-System of units as well as the symbols for chemical elements and compounds:

\begin{tabular}{|c|c|}
\hline$A A$ & Amino acid(s) \\
\hline AAR & Amino acid ratio \\
\hline Ala & Alanine \\
\hline $\mathrm{AME}_{\mathrm{N}}$ & Nitrogen corrected apparent metabolisable energy \\
\hline ANF & Anti-nutritive factor(s) \\
\hline anova & Analysis of variance \\
\hline Arg & Arginine \\
\hline Asp & Asparagine \\
\hline $\mathrm{BL}$ & Blue lupin \\
\hline $\mathrm{CA}$ & Crude ash \\
\hline CF & Crude fibre \\
\hline $\mathrm{CN}$ & Crude nutrient(s) \\
\hline $\mathrm{CP}$ & Crude protein \\
\hline CV & Coefficient of variation \\
\hline Cys & Cystine \\
\hline d21 & 21 days old broiler chicken \\
\hline $\mathrm{d} 42$ & 42 days old broiler chicken \\
\hline DM & Dry matter \\
\hline e. g. & exempli gratia = for example \\
\hline EAA & Essential amino acid(s) \\
\hline EE & Ether extract \\
\hline esp. & especially \\
\hline FB & Field bean \\
\hline FLD & Fluorescence detector \\
\hline FP & Field pea \\
\hline glm & Generalised linear model(s) \\
\hline Glu & Glutamine \\
\hline Gly & Glycine \\
\hline GMO & Genetically Modified Organism(s) \\
\hline His & Histidine \\
\hline HPLC & High performance liquid chromatography \\
\hline i. e. & id est $=$ that is \\
\hline IAAR & Ideal amino acid ratio \\
\hline
\end{tabular}




\begin{tabular}{|c|c|}
\hline lle & Isoleucine \\
\hline LED & light-emitting diode \\
\hline Leu & Leucine \\
\hline Lys & Lysine \\
\hline ME & Metabolisable energy \\
\hline Met & Methionine \\
\hline $\mathrm{n}$ & Number \\
\hline NfE & Nitrogen free extracts \\
\hline $\mathrm{O}$ & Oats \\
\hline $\mathrm{pc}$ & precaecal \\
\hline pcADC & Apparent precaecal digestibility coefficient \\
\hline pcSDC & Standardised precaecal digestibility coefficient \\
\hline Phe & Phenylalanine \\
\hline Pro & Proline \\
\hline $\mathrm{R}^{2}$ & Coefficient of determination \\
\hline SAA & Sulphur-containing amino acid(s) \\
\hline SB & Spring barley \\
\hline SD & Standard deviation of the mean \\
\hline SE & Standard error of the mean \\
\hline Ser & Serine \\
\hline SW & Spring wheat \\
\hline Thr & Threonine \\
\hline Trp & Tryptophan \\
\hline Tyr & Tyrosine \\
\hline Val & Valine \\
\hline WB & Winter barley \\
\hline WR & Winter rye \\
\hline WT & Winter triticale \\
\hline WW & Winter wheat \\
\hline
\end{tabular}




\section{List of Tables}

\section{General Introduction}

Table 1: Canonical proteinogenic amino acids and the ideal amino acid ratio in relation to lysine for fattening pig and growing chicken .....

Table 2: Transit time, $\mathrm{pH}$ value, and dry matter content of the digesta in the digestive tract of chicken*

\section{Chapter I}

Table I1: Total number of samples ( $\mathrm{n}$ total), number of samples considered for further statistical analyses ( $n$ subset), and number of factor manifestations for each cultivar

Table I 2: Chromatographic gradient conditions for the analysis of amino acids

Table I 3: Contents of crude nutrients, starch, and amino acids (means, standard deviations, minimum, and maximum in \% DM) in cereals and grain legumes.

Table 14: Contents of amino acids (means, standard deviations, minimum, and maximum in $\mathrm{g} / \mathrm{kg} \mathrm{DM}$ ) in cereals and grain legumes

Table 15: Contents of amino acids (means, standard deviations, minimum, and maximum in $\mathrm{g} / 16 \mathrm{~g} \mathrm{~N}$ ) in cereals and grain legumes......

Table 16: Amino acids related to lysine in cereals and grain legumes

Table I 7: Spearman correlation coefficients of the amino acids $(\mathrm{g} / 16 \mathrm{~g} \mathrm{~N})$ and crude protein (\% DM)

Table I 8: Factors affecting the content ( $\mathrm{g} / \mathrm{kg} \mathrm{DM}$ ) of crude nutrients and amino acids in selected cereals and grain legumes

\section{Chapter II}

Table II 1: Analysed amounts of crude nutrients and amino acids ( $/ \mathrm{kg} \mathrm{DM}$ ) in the test feedstuffs

Table II 2: Ingredients and calculated composition of the starter diet.

Table II 3: Ingredients and analysed composition ( $/ \mathrm{kg} \mathrm{DM}$ ) of the diets with the test feedstuffs bean (Vicia faba L.) and pea (Pisum sativum L.)

Table II 4: Coefficients of apparent precaecal digestibility (pcADC) of crude protein and amino acids in trial diets containing organically cultivated field beans (Vicia faba L.) and field peas (Pisum sativum L.) at three inclusion levels (g/kg DM) determined in 21-day-old broiler chickens 
Table II 5: Coefficients of standardised precaecal digestibility (pcSDC) of crude protein and amino acids in organically cultivated field beans (Vicia faba L.) and field peas (Pisum sativum L.) determined with a linear regression approach in 21-day-old broiler chickens

\section{Chapter III}

Table III 1: Content of crude protein (CP) and amino acids of feedstuffs available for the calibration of the in vitro method (\% DM)

\section{Chapter VI}

Table IV 1: Number of samples considered for statistical analyses (n), crude protein contents (CP in \% DM, $N^{*} 6.25$ ), and number of manifestations of the factors (variety, year, and site or area) for each cultivar

Table IV 2: In vitro crude protein (CP) and amino acid digestibility coefficients* of selected cereals and grain legumes as feedstuffs for 21-day old broiler chicken.

Table IV 3: In vitro crude protein (CP) and amino acid digestibility coefficients* of selected cereals and grain legumes as feedstuffs for 42-day old broiler chicken

Table IV 4: F- and p-values (in italics) of main factors in models describing varietal and environmental impact on the in vitro crude protein digestibility of selected cultivars for 21 - and 42-day old broiler chicken

\section{Chapter V}

Table V 1: Chromatographic gradient conditions for the analysis of riboflavin 108

Table V 2: Total number of samples ( $\mathrm{n}$ total), number of samples considered for further statistical analyses ( $n$ subset), and number of factor manifestations for each cultivar

Table V 3: Contents of thiamine and riboflavin in different cereal and legume grains $[\mathrm{mg} / \mathrm{kg} \mathrm{DM}]$

Table V 4: F- and p-values (in italics) of main factors in models describing varietal and environmental impact on the amounts of thiamine and riboflavin

\section{Chapter VI}

Table VI 1: Exemplary diets for swine in organic farming $[\mathrm{g} / \mathrm{kg} \mathrm{DM}]$

Table VI 2: Exemplary diets for poultry in organic farming $[\mathrm{g} / \mathrm{kg} \mathrm{DM}]$

Table VI 3: Contents of thiamine and riboflavin in different cereals and legumes [mg/kg DM] 
Table VI 4: Recommended and actual contents of B vitamins in exemplary diets for sows in organic farming $[\mathrm{mg} / \mathrm{kg} \mathrm{DM}]$

Table VI 5: Recommended and actual contents of B vitamins in exemplary diets for fattening pigs in organic farming [mg/kg DM] .

Table VI 6: Recommended and actual contents of B vitamins in exemplary diets for poultry in organic farming $[\mathrm{mg} / \mathrm{kg} \mathrm{DM}]$.

\section{List of Figures}

\section{Chapter III}

Figure III 1: In vitro rate of crude protein disappearance as a function of weigh in for one field pea sample......

Figure III 2: Stirring water baths with circulation thermostats

Figure III 3: Relation of the rate of crude protein (CP) disappearance in vitro with the in vivo precaecal (pc) digestibility coefficient of $\mathrm{CP}$ in a) 21 -day old and b) 42-day old broiler chicken

\section{Chapter IV}

Figure IV 1:In vitro crude protein digestibility coefficient of selected cereals and grain legumes in 42-day old broiler chicken. Bars illustrate factor manifestations of variety, year, and harvest site or area with the minimum and maximum contents (Ismeans and standard errors), "mark significant differences $(p<0.05)$. See Appendix for more detailed information.

\section{Chapter V}

Figure V 1: Content of thiamine and riboflavin in cereal grains; Bars illustrate factor manifestations of variety, year, and harvest site or area with the minimum and maximum contents. See supplements for more detailed information.. 113

Figure V 2: Content of thiamine and riboflavin in grain legumes; Bars illustrate factor manifestations of variety, year, and harvest site or area with the minimum and maximum contents. See supplements for more detailed information.. 114

\section{General Discussion}

Figure 1: Origin of excreted nitrogen (adapted from McDonald et al. 2002)....... 



\section{Summary}

The sufficient supply of nutrients, in particular of protein and amino acids, for monogastric animals in organic farming is challenging. For one thing, some feedstuffs that are rich in crude protein and contain large amounts of valuable amino acids are not available in organic quality. Additionally, the use of synthetic amino acids to compensate imbalances of amino acids is not allowed according to EU regulations. To improve the situation in organic farming, efforts are made in animal breeding and husbandry as well as in plant breeding. Furthermore, alternative protein feedstuffs are studied with regard to their use in monogastric animal feeding. Besides the supply of amino acids, the supply of $B$ vitamins is potentially challenging. Riboflavin supplements are primarily produced using fermentation. Thus, the market availability of GMO-free riboflavin supplements is inadequate. The knowledge on native contents of B vitamins in feedstuffs is scarce. Consequently, it is important to characterise commonly used feedstuffs. Since organic farming aims for a local production, cereals and grain legumes are frequently used as feedstuffs. The aim of this study was, therefore, to characterise organically produced cereal and grain legume seeds based on their contents of crude nutrients, amino acids, thiamine, and riboflavin considering influences of variety and environmental conditions.

For this purpose, more than 800 samples were derived in three years from organic variety trials, which were conducted by the German Chambers of Agriculture as well as the German experimental stations, and analysed for the aforementioned ingredients. Furthermore, the crude protein and amino acid digestibility in young broiler chicken was assessed in vivo and in vitro. The precaecal digestibility of the crude protein and the amino acids of a field bean and a field pea variety, which are commonly used in organic farming, was determined in vivo in 21-day-old broiler chicken. To predict the praecaecal digestibility of the crude protein and the amino acids of feedstuffs for broiler chicken, a multi-enzyme assay was adapted. The in vitro digestibility of the crude protein and amino acids of cereals and grain legumes was then determined using the adapted assay. The effect of variety and environment on the contents of crude nutrients, amino acids, thiamine and riboflavin, as well as on the in vitro digestibility of the crude protein and the amino acids in cereals and grain legumes was studied with generalised linear models. In addition, native contents of thiamine and riboflavin of exemplary diets for monogastric animals in organic farming were calculated.

As reported earlier in the literature, wide variations of the nutrient composition were also observed in the present study. However, the crude protein and amino acid contents of cereals and grain legumes were often lower and the starch content was often higher than reported in feed value tables.

The precaecal digestibility of crude protein of organic field beans and field peas was comparable to reported digestibility coefficients with $84 \%$ and $81 \%$, respectively. Lysine, 
methionine, arginine, histidine and glutamic acid were highly digestible at the terminal ileum, while cystine and tryptophan were less digestible. The in vitro crude protein disappearance that was determined with the adapted multi-enzyme assay was highly correlated to the precaecal crude protein and the amino acid digestibility that was determined in preceding animal trials. The in vitro digestibility coefficients differed by more than 0.1 within a cultivar. They were mostly comparable to reported values in tables or digestibility studies. However, a comparison was difficult due to wide variations between table values and results of other studies. Since the number of samples with known precaecal crude protein and amino acid digestibility was small, further validation of the in vitro assay is recommended.

The composition and the in vitro crude protein and amino acid digestibility of the cereal and grain legume cultivars were significantly affected by variety and by environmental conditions. In most cases, the influence of the environmental conditions was stronger. However, the extent and the direction of the influence of these factors were not consistent and may be depending on interactions and the choice of the sample set. It was observed for all cultivars that variations of the crude protein content were accompanied by an altered amino acid profile. The content of essential amino acids, including lysine, methionine, and threonine, in the crude protein were often negatively correlated with the crude protein content. A positive correlation with the crude protein content was observed for glutamic acid, phenylalanine, and proline in the crude protein of different cereal grains as well as for arginine in the crude protein of grain legumes. This is most likely due to shifts in the relation of the protein fractions of the crops. Consequently, the crude protein quality tended to decrease with increasing crude protein contents of the feedstuffs.

Although the analysed amounts of thiamine in cereals and grain legumes were low compared to table values, calculated cereal-based diets contained sufficient amounts of native thiamine to meet current feeding recommendations. However, it must be noticed that the availability of thiamine was not taken into account. The native riboflavin contents of the exemplary diets were lower than the recommended amounts. Thus, it is necessary to use riboflavin supplements or feedstuffs rich in riboflavin to prevent deficiencies.

In conclusion, the observed wide variations of the nutrient contents as well as of the crude protein and amino acid digestibility of organically cultivated cereals and grain legumes must be considered in diet formulation. While amino acid contents can already be predicted with equations based on the crude protein content of the feedstuff, rapid and cheap analysis methods are needed to determine crude nutrient and possibly even B vitamin contents of each batch of a feedstuff. Consequently, the contribution of cereals and grain legumes to closing the amino acid gap in organic farming would be further improved. Moreover, their native thiamine and riboflavin content adds to the $B$ vitamin supply. 


\section{Zusammenfassung}

Die adäquate Versorgung monogastrischer Nutztiere mit Nährstoffen, vor allem mit Protein und Aminosäuren, ist im Ökologischen Landbau eine Herausforderung. Einerseits sind einige proteinreiche Futtermittel mit hohen Gehalten an essentiellen Aminosäuren nicht verfügbar, andererseits ist der Einsatz synthetischer Aminosäuren zum Ausgleich von Aminosäurenimbalancen laut EU Gesetzgebung nicht erlaubt. Um diese Situation zu verbessern, gibt es Bemühungen in der Pflanzen- und Tierzucht, sowie in der Tierhaltung, und es wird aktiv nach alternativen Proteinfuttermitteln gesucht. Neben der Aminosäurenversorgung stellt auch die Versorgung mit B-Vitaminen potentiell ein Problem dar. Vor allem bei vorrangig fermentativ produzierten B-Vitaminen, wie Riboflavin, sind GMO-freie Supplemente nicht verfügbar. Das Wissen über native B-Vitamingehalte in Futtermitteln ist lückenhaft. Daher ist es notwendig, auch häufig eingesetzte Futtermittel zu charakterisieren. Da im Ökologischen Landbau eine regionale Erzeugung angestrebt wird, haben Getreide und heimische Körnerleguminosen eine große Bedeutung. Das Ziel dieser Arbeit war folglich die Charakterisierung von Getreide und Körnerleguminosen aus ökologischer Erzeugung anhand ihres Rohnährstoff-, Aminosäuren-, Thiamin- und Riboflavingehalts unter Beachtung von Sorten- und Umwelteinflüssen.

Zu diesem Zweck wurden über 800 Proben aus drei Anbaujahren aus ÖkoSortenversuchen der deutschen Landwirtschaftskammern und Landesversuchsanstalten auf die Gehalte der oben genannten Inhaltsstoffe analysiert. Zudem wurde die praecaecale Verdaulichkeit des Rohproteins und der Aminosäuren bei 21 Tage alten Broilern exemplarisch an einer Öko-Futtererbse und einer Öko-Ackerbohne untersucht. Um die praecaecale Rohprotein- und Aminosäurenverdaulichkeit für Broiler zu schätzen, wurde eine Multi-Enzym-Methode adaptiert. Mit Hilfe der adaptierten Methode ist die in vitro Verdaulichkeit des Rohproteins und der Aminosäuren verschiedener Getreide- und Körnerleguminosenarten überprüft worden. Des Weiteren wurden der Einfluss von Sorte und Umwelt auf die Gehalte an Rohnährstoffen, Aminosäuren, Thiamin und Riboflavin sowie auf die in vitro Verdaulichkeit des Rohproteins und der Aminosäuren in Getreide und Körnerleguminosen mittels generalisierter linearer Modelle bestimmt und der native Gehalt an Thiamin und Riboflavin in Beispielrationen für monogastrische Nutztiere berechnet.

Wie erwartet, schwankte die Nährstoffzusammensetzung stark. Zudem waren die Gehalte an Rohprotein- und vielen Aminosäuren häufig geringer und die Stärkegehalte in Getreide und Körnerleguminosen höher als tabellierte Werte.

Das in Erbsen und Ackerbohnen enthaltene Rohprotein war zu 84 und 81\% praecaecal verdaulich. Dies war vergleichbar mit Ergebnissen anderer Studien. Lysin, Methionin, Arginin, Histidin und Glutamin waren hoch verdaulich. Die praecaecale Verdaulichkeit von Cystin und Tryptophan war jedoch geringer. Mit der adaptierten Multienzymmethode 
wurden Rohproteinverschwindensraten bestimmt, die stark mit der praecaecalen Verdaulichkeit des Rohproteins und der Aminosäuren, die in vorangegangenen Studien bestimmt wurde, korreliert waren. Die in vitro Verdaulichkeitskoeffizienten unterschieden sich zum Teil um mehr als 0,1 innerhalb einer Kultur. Insgesamt waren sie häufig vergleichbar mit Literaturangaben zur praecaecalen Rohproteinverdaulichkeit in Getreide und Körnerleguminosen. Ein Vergleich war aufgrund großer Unterschiede zwischen den Tabellenwerten und Literaturergebnissen jedoch schwierig. Da die Grundlage an in vivo Ergebnissen gering war, wird eine weitere Validierung der Methode empfohlen.

Die Nährstoffzusammensetzung und die in vitro Rohprotein- und Aminosäurenverdaulichkeit von Getreide und Körnerleguminosen wurden signifikant von der Sorte und den Umweltbedingungen beeinflusst, wobei in den meisten Fällen der Einfluss der Umweltbedingungen überwog. Das Ausmaß und die Richtung dieser Effekte waren jedoch nicht konsistent. Wechselwirkungen und die Auswahl der Proben können Gründe dafür gewesen sein. Für alle Kulturen wurde beobachtet, dass eine Veränderung des Rohproteingehaltes ein verändertes Aminosäurenmuster zur Folge hatte. Die Gehalte an essentiellen Aminosäuren, wie Lysin, Methionin oder Threonin, im Rohprotein waren oft negativ mit dem Rohproteingehalt korreliert. In Getreide stieg die Konzentration an Glutamin, Phenylalanin und/oder Prolin mit steigenden Rohproteingehalten, in Körnerleguminosen stieg vor allem die Konzentration an Arginin im Rohprotein. Der Grund dafür war wahrscheinlich eine Veränderung im Verhältnis der Proteinfraktionen zueinander. Diese kann zu einer veränderten Proteinqualität führen.

Getreidebasierte Beispielrationen enthielten ausreichende Mengen an Thiamin, um aktuelle Bedarfsempfehlungen zu decken, obwohl die Thiamingehalte in Getreide und Körnerleguminosen meist geringer waren als in der Literatur beschrieben. Es ist jedoch zu beachten, dass die Verfügbarkeit des Thiamins nicht berücksichtigt worden ist.

Die nativen Riboflavingehalte in den Beispielrationen reichten nicht aus, um den Bedarf zu decken. Um Mangelerscheinungen zu vermeiden, ist es daher notwendig, Riboflavin zu supplementieren oder riboflavinreiche Futtermittel einzusetzen.

Zusammenfassend kann aus der vorliegenden Arbeit die Empfehlung abgeleitet werden, dass die starken Schwankungen der Nährstoffgehalte und der in vitro Verdaulichkeit des Rohproteins und der Aminosäuren in Öko-Getreide und -Körnerleguminosen in der Rationsgestaltung berücksichtigt werden müssen. Während für die Aminosäurengehalte bereits zufriedenstellende Schätzgleichungen auf Basis des Rohproteingehalts existieren, werden zur Bestimmung der Rohnährstoff- und B-Vitamingehalte in Futtermittelchargen noch schnelle und günstige Analysemethoden benötigt. Dadurch könnten Getreide und Körnerleguminosen noch besser zur Schließung der Aminosäurenlücke im Ökologischen Landbau beitragen. Auch ihr nativer Gehalt an Thiamin und Riboflavin kann einen Beitrag zur bedarfsgerechten Versorgung monogastrischer Nutztiere leisten. 


\section{General Introduction}

\section{$1 \quad$ Feeding monogastric animals in organic farming}

\section{Challenges}

Organic production is subject to strict regulations, the purpose of which is to ensure sustainable agricultural production ${ }^{2}$. As a consequence, some of these regulations largely affect monogastric animal feeding. For instance, it is not allowed to use feedstuffs produced with solvents, such as extraction meals, which are important protein feedstuffs in conventional agriculture. Extraction meals are rich in crude protein (CP) and often contain considerable amounts of limiting amino acids (AA) (DLG 2006-2010, 2014). Furthermore, genetically modified organisms (GMO) are banned in organic farming. Most existing soybean varieties are genetically modified (Bachteler 2015) and, therefore, cannot be used. Due to production techniques that include fermentation with GMO (Ikeda 2003), the use of synthetically produced $A A$, a supplement commonly fed in conventional farming, is forbidden in organic farming. Since B vitamins, like riboflavin, are also often produced by fermentation with GMO (Stahmann et al. 2000, Schwechheimer et al. 2016), it is desired to supply sufficient amounts of $B$ vitamins in the diet with native contents in the feedstuffs. Thiamine, for example, is supposedly contained in cereals in large amounts (Sauvant et al. 2004). Thus, cereal-based diets might contain sufficient amounts of thiamine (GfE 1999, 2006), while other B vitamins, like riboflavin, are more likely to be deficient. To avoid deficiencies, it is currently allowed to use some B vitamin supplements in diets for farm animals in organic farming. In addition, organic farming aims for $100 \%$ organic feeding. Thus, limitations in cultivation techniques further decrease the availability of valuable feedstuffs. For example, rapeseed, which is an oil seed with high amounts of sulphurcontaining AA (SAA), is difficult to cultivate in organic farming due to pests (Velicka et al. 2016). The lack of some feedstuffs and of good alternatives makes it more difficult to meet the nutrient requirements of monogastric animals. Thus, it can be necessary to exceed the required amounts of crude protein of the diet to attain the needed amount of essential $A A$ (EAA). This practice can lead to an imbalance of amino acids in the diets (Jongbloed \& Lenis 1992, Chalova et al. 2016) and, consequently, to excessive N-excretions (Canh et al. 1998, Le Bellego \& Noblet 2002, Wecke \& Liebert 2013b, Chalova et al. 2016), which can burden the metabolism, the environment, and the staff working in the stalls. Moreover, unbalanced diets can cause a decreased performance (Sundrum et al. 2000) as well as a higher probability of cannibalism, feather pecking (Kjaer \& Sørensen 2002, Van Krimpen et al. 2005), stunted growth, and health problems (Jongbloed \& Lenis 1992, Nagaraj 2006,

\footnotetext{
${ }^{2}$ Framework can be found in Council Regulation (EC) No 834/2007 and associated Commission Regulations
} 
Oviedo-Rondón et al. 2006, Heo et al. 2009). In organic farming, the sufficient supply of AA is challenging in both swine and poultry. However, according to Weißmann \& Bussemas (2014), it is most problematic in broiler and turkey nutrition. Furthermore, since the extent of poultry production is expanding, while the one of pig production is stagnating (Eurostat 2018, Moewius et al. 2018), the topic is more pressing for poultry.

\section{Potential solutions}

Negative effects of AA deficient diets on the health of monogastric animals in organic farming are to be avoided. Thus, their diet is currently allowed to contain $5 \%$ conventionally produced protein feedstuffs per year. Due to their high CP content and a favourable AA profile, potato protein (esp. for swine) and maize gluten (esp. for poultry) from conventional farming are commonly used to enhance the nutritive value of diets for monogastric animals (Hovi et al. 2003, Eriksson et al. 2009). Regarding 100\% organic feeding, it seems obvious to replace the conventional protein isolates with organic ones. However, they are a byproduct of starch production. Since the demand for organic potato and maize starch is low, protein isolates in organic quality are not available in sufficient amounts (Witten \& Paulsen 2014). Consequently, other potential solutions are needed to close the amino acid gap for $100 \%$ organic feeding. Some farmers have found individual ways to feed their animals with $100 \%$ organic feed. However, it is not possible to use their concepts nationwide for all monogastric animals as they often depend on local producers of special feedstuffs (like organic potato protein). Thus, further endeavours have to be made to provide enough valuable protein feedstuffs for all monogastric animals. Since there is not one comprehensive solution, different strategies are discussed. It is likely that a combination of those approaches is needed to implement 100\% organic feeding (Witten \& Paulsen 2014).

The first approach is to use possibilities of the animals' genetics and metabolism. Monogastric animal breeding could adjust poultry for low protein diets in organic farming (Elwinger et al. 2008). The breeding of robust, modest, and efficient new turkey and dualpurpose chicken races would contribute to solving the problem. However, breeding of pigs for organic farming is difficult due to a small population and the lack of specialised breeders (Weißmann 2017). Berk \& Weißmann (2012) suggested the use of compensatory growth for pigs. They found out that a decreased growth of piglets due to less crude protein in the diet can be compensated later on. Additionally, this strategy has the potential to be used in chicken feeding (Zhan et al. 2007). Another option would be to decrease the energy density of the feedstuff, which leads to an increased feed intake in poultry and therefore to an improved protein and AA intake (Bellof \& Schmidt 2007). However, young poultry would have to be adapted to high feed intake (Baumann 2004, Joost Meyer zu Bakum 2004). 
The second approach is to support plant breeding and cultivation. It is well known that due to genetic factors varieties of cultivated crops can differ in many characteristics, like yield quantity and stability, pest resistances, and even nutrient composition (Francis \& Kannenberg 1978, Blumenthal et al. 1991, Khush 1995, Snape et al. 2007). Commonly used plants, like cereals, maize, peas, field beans, sweet lupins, sunflowers, canola, or soybeans, could be further improved and adapted for new environmental conditions and nutritional needs. Moreover, less popular plants, like vetch, millet, or buckwheat, could be further developed. Therefore, it is possible that plant breeding strategies can contribute to a regional $100 \%$ organic feeding. However, due to the priority of other breeding aims, like pest resistances or high yield, and the small purchase volume in organic farming, this approach is rather to be seen as a long-term solution.

The third approach is the use of alternative protein feedstuffs. Possible alternatives include insect protein, unsuitable meat from slaughtering, microorganisms (like bacteria, yeast, and algae), fish or mussel meal, milk products, egg products, treated legumes, or oil cakes. Unfortunately, the mentioned feedstuffs can yet not be used, are only available in small amounts, and/or are very expensive (Witten \& Paulsen 2014). In addition, germinated grains (Schwediauer et al. 2017) and grassland-derived products (Wüstholz et al. 2017a, Wüstholz et al. 2017b) can be used as alternative protein feedstuffs to improve the amino acid supply of a diet.

The fourth approach is to improve feed evaluation and ration formulation. Organic farms often cultivate their own single feedstuffs to minimise nutrient input into the farm (Zollitsch 2007). Cereal grains and grain legumes are, therefore, major components of diets. The general nutrient composition of fodder crops is mainly known and summarised in different feed value tables (e. g., Ajinomoto Animal Nutrition Group 2003-2013, DLG 2006-2010, Agroscope 2011-2016, Evonik 2016, INRA-CIRAD-AFZ 2018). However, the nutrient composition of crops can vary widely due to genetic and environmental factors (Canbolat et al. 2007, Shewry et al. 2011, Urbatzka et al. 2011). Thus, there is a lack of knowledge regarding the nutrient composition of batches of single feedstuffs produced on a local level. Laboratory analyses can generate specific information on each feedstuff.

Feed evaluation and ration formulation are important in addressing the above-described challenges regardless of the additional solutions pursued. Thus, the topic of the next chapter is the characterisation of feedstuffs. 


\section{Characterisation of feedstuffs}

Since feed evaluation can add to animal health, animal performance, and nutrient conservation, it contributes to making animal feeding more sustainable and efficient (Le Bellego \& Noblet 2002). It is, therefore, of special importance in agricultural production. This chapter provides an overview of selected feed ingredients and focuses on amino acids and their digestibility.

\section{Crude nutrients}

For the evaluation of feed quality on the basis of its nutrient composition, fractions consisting mostly of the nutrients that are important for feed quality are analysed with Weende analysis as a first step. Since those fractions also contain traces of foreign substances, they are called crude nutrients $(\mathrm{CN})$. CP, for example, is calculated from the $\mathrm{N}$ content of the feedstuff. Thus, it contains also non-protein $\mathrm{N}$ compounds, like nucleic acids, and some secondary plant metabolites. The other $\mathrm{CN}$ fractions are crude fat (ether extract, EE), crude fibre (CF), crude ash (CA), and nitrogen-free extracts (NfE). The minerals are mostly contained in the CA fraction. CF and NfE can be further characterised by the amount of sugar, starch, neutral detergent fibre, acid detergent fibre, and acid detergent lignin (Van Soest 1967). CN contents can also be used to calculate the energy content of different feedstuffs.

All CN fractions contain vital compounds. However, this chapter focuses on a more detailed description of the composition and digestion of CP because its sufficient supply for monogastric animals is a challenging task in organic farming.

\section{Amino acids}

Monogastric animals require the $\mathrm{AA}$, which are contained in the $\mathrm{CP}$ fraction, to build structural proteins and hormones. Of 21 proteinogenic AA, 20 AA are the canonical ones and, therefore, are encoded by the universal genetic code. Non-essential AA can be built de novo by the organism when nitrogen $(N)$ is present in sufficient amounts. However, animals are not capable of building all $A A$. Essential $A A(E A A)$ must be included in the diet in sufficient amounts, whereas semi-essential $A A$ are either essential in specific metabolic states (like growth) or can be derived from essential $A A$. Thus, monogastric animals require semi-essential and essential $A A s$ as well as $A A$ building components (like $N$ ) or nonessential AA (Wu et al. 2013) in amounts depending on species, breed, age, and metabolic state (like maintenance, growth, gestation, lactation) of the animal (Fuller 2004). To build proteins (like tissues or animal products), animals require $A A$ in a specific profile. Consequently, the use of excess $A A$ by the metabolism is limited when one of the EAA is not supplied sufficiently. While lysine (Lys) is limiting the protein utilisation in common cereal-based diets for swine, the SAA, methionine (Met) and cystine (Cys), are limiting in 
most diets for poultry. Besides Lys and the SAA, threonine (Thr) and tryptophan (Trp) are considered as limiting $A A$ in common cereal-based diets for monogastric animals (Fuller 2004). Although the absolute amount of required AA is dependent on many factors, their optimal ratio is relatively stable (Baker et al. 2002, Baker 2003). Based on this knowledge, the quality of the dietary protein is measured using the ideal amino acid ratio (IAAR), which describes the required ratio of $A A$ in relation to a reference $A A$ (Table 1 ).

Table 1: Canonical proteinogenic amino acids and the ideal amino acid ratio in relation to lysine for fattening pig and growing chicken

\begin{tabular}{|c|c|c|c|c|c|}
\hline Amino Acid & & Essentiality & Class & $\begin{array}{c}\text { Fattening } \\
\text { pig }^{1}\end{array}$ & $\begin{array}{l}\text { Growing } \\
\text { chicken? }\end{array}$ \\
\hline Lysine & Lys & e & Basic & 100 & 100 \\
\hline Methionine & Met & e & Sulphur-containing & & 40 \\
\hline Cyst(e)ine & Cys & s & Sulphur-containing & $60^{*}$ & $74^{*}$ \\
\hline Threonine & Thr & e & Aliphatic & 65 & 66 \\
\hline Tryptophan & Trp & e & Aromatic & 18 & 16 \\
\hline Isoleucine & Ile & e & Aliphatic & 60 & 69 \\
\hline Leucine & Leu & e & Aliphatic & 100 & 110 \\
\hline Valine & Val & e & Aliphatic & 68 & 80 \\
\hline Arginine & Arg & $s / e^{\#}$ & Basic & 42 & 105 \\
\hline Histidine & His & e & Basic & 32 & 34 \\
\hline Phenylalanine & Phe & e & Aromatic & & 66 \\
\hline Tyrosine & Tyr & s & Aromatic & $95^{\star *}$ & $120^{* *}$ \\
\hline Alanine & Ala & $\mathrm{n}$ & Aliphatic & & \\
\hline Glycine & Gly & $n / s^{+}$ & Aliphatic & & \\
\hline Serine & Ser & $\mathrm{n} / \mathrm{s}^{+}$ & Aliphatic & & \\
\hline Proline & Pro & $\mathrm{n}$ & Cyclic & & \\
\hline Asparagine & Asn & $n$ & Acidic Amid & & \\
\hline Aspartic acid & Asp & $n$ & Acidic & & \\
\hline Glutamine & Gln & $\mathrm{n}$ & Acidic Amid & & \\
\hline Glutamic acid & Glu & $\mathrm{n}$ & Acidic & & \\
\hline
\end{tabular}

e=essential; $\mathrm{s}=$ semi-essential; $\mathrm{n}=$ non-essential; ${ }^{1}$ Chung \& Baker $(1992) ;{ }^{2}$ Wecke \& Liebert (2013a); * Met+Cys; ${ }^{* *}$ Phe+Tyr; \# Arginine is essential for poultry because of the lack of ornithine cycle (Fuller 2004); ${ }^{+}$semiessentiel in fast-growing poultry (Jeroch et al. 2012)

Lys is commonly applied as reference AA since it is often first-limiting and used mainly in the formation of body proteins (Baker et al. 2002). However, the Lys requirement, which must be known, depends on characteristics of the animal (Wecke et al. 2016). The IAAR concept aims to supply each AA in accordance with the rendered performance of the animal. The composition of dietary protein is ideal when neither an increased nor a decreased supply of an AA leads to an enhanced performance. The concept is used in swine and poultry nutrition (NRC 1994, GfE 1999, 2006, NRC 2012) to increase the efficiency and sustainability due to a decreased need for protein without a diminished performance (Mack et al. 1999). Since a decreased $N$ uptake relieves the metabolism and decreases the $N$ content of animal manure, the environment and the animal health benefit from the IAAR (Le Bellego \& Noblet 2002, Boisen 2007b). Thus, it is of advantage for nutritionists to know the content of the $A A$ in the diet. However, the animal is not able to digest the dietary protein entirely (Recoules et al. 2017). Thus, only dietary AA that can be digested and absorbed are potentially metabolically available for the animal. 


\section{Digestion of protein}

In the digestive tract of monogastric animals, enzymes are used to split proteins into peptides and AA, which can then be absorbed, mostly in the small intestine, and used as building blocks of tissues, enzymes, and hormones. In this chapter, the digestion of protein is described specifically for chicken. As shown by Table 2, the transit time, the amount and composition of secretions, as well as the $\mathrm{pH}$ value of the digestive tract vary depending on characteristics of the animal and the ingested material (Farner 1943, Kokas et al. 1971, Shires et al. 1987, Fuller 2004, Denbow 2015). In chicken, the ingested feed is initially stored and soaked in the crop in a fluid of mucus and saliva. The $\mathrm{pH}$ depends on the characteristics and contribution of the feed and can vary widely (Shafey et al. 1991, Richter et al. 1992, Hinton et al. 2000, Józefiak et al. 2007, Jiménez-Moreno et al. 2009). Although no enzymes are secreted from the crop tissue, enzymes of the plant feedstuff itself (Harvey \& Oaks 1974, Morita et al. 1994, Fahmy et al. 2004) and of microorganisms (Champ et al. 1983) can hydrolyse parts of the nutrients in the crop. However, the crop is mainly a storage organ (Denbow 2015). The feed is continuously released from the crop to be further digested.

Table 2: Transit time, $\mathrm{pH}$ value, and dry matter content of the digesta in the digestive tract of chicken*

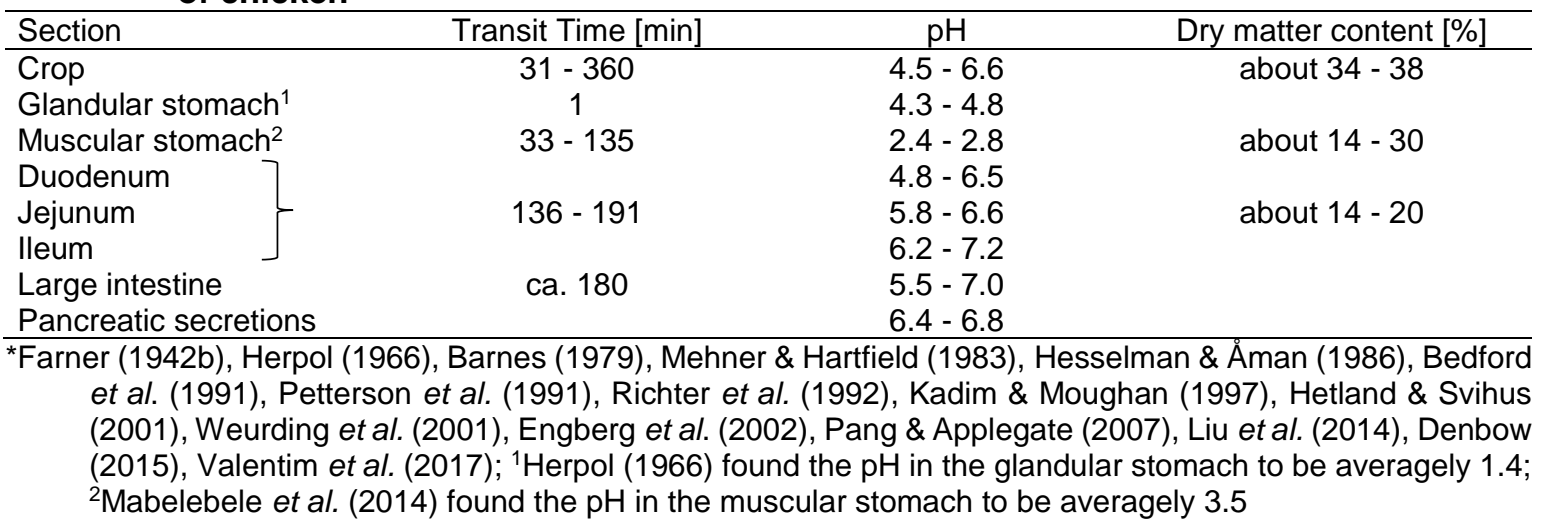

The oxynticopeptic cells in the glandular stomach secrete pepsinogen and hydrochloric acid $(\mathrm{HCl})$. Pepsinogen is the proenzyme of the protein-hydrolysing enzyme pepsin, activated by $\mathrm{HCl}$. Long (1967) observed a basal gastric secretory rate of $15.4 \mathrm{ml}$ per hour with $93 \mathrm{mEq}$ pepsin per litre. The optimal operating $\mathrm{pH}$ of pepsin is in the acidic range. Due to the low $\mathrm{pH}$ in the muscular stomach (Table 2), the structure of the dietary protein is altered, which enables pepsin to break it down into smaller peptides. The muscular stomach contains grit, which is supplied with the diet and assists in grinding the feed particles during the digestion with $\mathrm{HCl}$ and pepsin. A large amount of protein is released from the stomach in form of small peptides (Recoules et al. 2017).

In the small intestine, luminal digestion and digestion at the brush border membrane take place. Enzymes of the brush border membrane are aminopeptidases, cytosolic dipeptidases, and tripeptidases. Recoules et al. (2017) identified the proteins in the 
digestive tract of broilers and found a variety of enzymes. The highest enzyme activity can be observed in the jejunum. However, little is known about the control mechanisms of intestinal secretions (Denbow 2015). Pancreatic secretions are the main factor accountable of protein digestion in the small intestine. They consist of an aqueous phase, which contains water and bicarbonate ions, and an enzymatic phase, which includes $10 \%$ trypsinogen, $20 \%$ chymotrypsinogen, and $30 \%$ procarboxipeptidase (Pubols 1991). The secretory rate is affected by characteristics of feedstuff and starvation time (Kokue \& Hayama 1972, 1976) and is in part controlled by autonomic nerves and gastrointestinal hormones (gastrin, secretin, and cholecystokinin) (Burhol 1982, Polak \& Bloom 1982). Pancreatic secretions are secreted into the distal duodenum. However, since there is a tailback of digesta, they can be found even in the proximal duodenum (Denbow 2015). The $\mathrm{pH}$, therefore, increases between the proximal and distal duodenum and further in the jejunum and ileum (Table 2). AA absorption can be observed in the crop and the stomach. AA as well as small peptides are absorbed along the duodenum, jejunum, and ileum (Matthews 1972, Denbow 2015). When digesta has left the small intestine, it is subject to microbial digestion in the large intestine. The absorption of some AA (Met in the rectum and Pro, Leu, Phe, Met, Val in the caeca) has been observed in the large intestine of hens. However, the small intestine is presumed to be the main site of AA and peptide absorption (Moretó \& Planas 1989, Fuller 2004).

Since AA must be absorbed to become available for metabolic use, the digestibility of the protein of a feedstuff is used as an indicator for the bioavailability of CP and AA. Therefore, knowledge on the CP and AA digestibility gained in importance in diet formulation (Dalibard \& Paillard 1995, Perttilä et al. 2002). Microbial fermentation in the caeca of poultry modifies the CP content as well as the AA profile of their digesta (Ravindran et al. 1999). Therefore, there is a large difference between total tract digestibility and metabolic availability of CP and $A A$. Thus, the precaecal (pc) digestibility of CP and AA is used in diet formulation.

\section{Predicting crude protein and amino acid digestibility}

By now, the pc digestibility of most nutrients, including CP and some AA, is summarised in tables (Hess \& Lemme 2018). However, table values vary widely dependent on characteristics of the assay methodology (Bryden et al. 2009) and are not able to display variations that occur between different batches of the same feedstuffs (Short et al. 1999, Rodehutscord \& Kluth 2003, Wiseman et al. 2003). Anti-nutritive factors (ANF) and fibre contents of the diet affect nutrient digestibility. A treatment of a feedstuff, for example with heat or steam, can also alter the CP and AA digestibility (Toghyani et al. 2015, Hejdysz et al. 2016). To determine the apparent or true (corrected for endogenous losses) pc digestibility of $\mathrm{CP}$ and $\mathrm{AA}$ in vivo assays can be used. Furthermore, in vitro assays are able to estimate the Pc CP and AA digestibility. 


\section{In vivo prediction of crude protein and amino acid digestibility in poultry}

A selection of different assays exists to determine the digestibility of $C P$ and $A A$ in chicken. Some methods, like the surgical installation of an ileal cannula (Johns et al. 1986) are not commonly used. The digestibility of nutrients in feedstuffs for poultry is by now commonly determined using the excreta of cecectomised roosters or the ileal chyme of young broiler chicken (Doeschate et al. 1993, Ravindran \& Bryden 1999, Kadim et al. 2002).

A cecectomy is usually conducted on adult animals and is fairly expensive. Therefore, operated animals are used for more than one study and repetitions are made continuingly with the same animal. Total excreta collection or a marker can be used in this method. However, since the gastro-intestinal-tract and its microflora develops continually until adulthood, the CP and AA digestibility can vary as well (Batal \& Parsons 2002, Ravindran \& Hendriks 2004). Thus, the results of rooster assays are not applicable for juvenile chicken. Broiler chicken in organic farming are fattened for about eight weeks. Thus the critical time regarding the sufficient supply of $A A$ is during the juvenile phase. To determine the $\mathrm{pc}$ digestibility of younger animals at a specific age, ileal digesta samples are taken from killed animals after rearing them for a specific time-span. This methods require a marker to adjust for the passage rate of the digesta. Furthermore, this method requires more animals to gain enough digesta for the nutrient analyses and to ensure enough repetitions. A specific age is displayed and the influence of the individual is obliterated.

There are various effects of the method, like feeding technique (Kadim \& Moughan 1997), sampling time after ingestion (Kadim \& Moughan 1997) or sampling technique (Parsons 1985, Johns et al. 1986, Kadim et al. 2002) on the determined pc digestibility. Furthermore, effects of the animal, like age (Batal \& Parsons 2002, Ravindran \& Hendriks 2004), sex (Doeschate et al. 1993, Siriwan et al. 1993), or breed (Doeschate et al. 1993) were reported. Thus, it can be misleading to compare results obtained from different methods and to make a statement for animals in another metabolic state or age. To determine true or standardised pc digestibility of CP and AA, endogenous losses must be quantified (Karakas et al. 2001, de Coca-Sinova et al. 2008, Kim et al. 2011b, Adedokun et al. 2014). However, there is no standardised method to quantify endogenous losses (Donkoh \& Moughan 1999, Cremers 2002, Jansman et al. 2002). The benefit of a regression approach, as used in different studies (Short et al. 1999, Kluth et al. 2005b), is that no correction for basal endogenous losses is necessary (Rodehutscord et al. 2004). The slope of the linear regression accounts practically for the standardised $\mathrm{pc}$ digestibility of the CP or the AA.

Consequently, Kluth \& Rodehutscord (2009) suggested the use of a standardised method. They invented a method to measure the standardised pc digestibility of CP and AA in chicken (Kluth et al. 2005a, Kluth et al. 2009) with a linear regression approach 
(Rodehutscord et al. 2004) using the amounts of nutrient intake and of nutrient residuals at the terminal ileum. This method was also used in the present study.

The advantage of animal experiments is that the animals' metabolism is naturally part of the study. Distinct statements regarding the pc digestibility of the observed nutrients in the used animals can be made after such an experiment. The difficulty is that the animals' ability to digest the nutrients is depending on their enzyme reaction. It is affected by genetic and environmental factors and can therefore differ in diverse experiments (Fuller et al. 1994). Changes in substrate intake lead to an adaption of the digestive enzymes and can therefore modify the digestive capacity (Eggum et al. 1989, Savoie et al. 1989). Even ANF can influence enzyme secretion (Mehanso et al. 1987). Lectins increase cellular turnover and protein secretion of the enterocytes (Pusztai 1989) and, therefore, endogenous losses. Fibre can lead to anatomical changes in the digestive tract (Eggum \& Boisen 1991), reduce luminal enzyme activity, and protect proteins against degradation (Boisen et al. 1985). Furthermore, the gastro-intestinal microflora can influence digestion even in the stomach and small intestine, for example by degrading and synthesising individual AA (Mason 1984). Even genetic and environmental factors strongly affect feed utilization. In a study conducted by Elbers et al. (1989), the same diet had a varying organic matter digestibility when fed to pigs on different farms. This observation might be transferable to other nutrients and animals. Consequently, results of in vivo digestibility studies do not necessarily display the net absorbed AA. Another disadvantage of in vivo studies is that they are time-consuming and costly and that animals need to be operated or killed to generate results. Thus, in vitro methods can be of interest for a replicable, rapid, and cheap characterisation of feedstuffs.

In vitro prediction of crude protein and amino acid digestibility

In vitro assays for the estimation of $\mathrm{CP}$ and $\mathrm{AA}$ digestibility should be rapid, cheap, and robust. Regarding the described variations, which occur due to feed- and animal-related factors, respectively, as well as interactions between those factors, in vivo conditions cannot be replicated by in vitro assays. Thus, in vitro studies characterise feedstuffs mostly independent of the animal-related effects. Nevertheless, their applicability is dependent on a high correlation with results of in vivo studies (Butts et al. 2012). In the last decades, different assays were developed to predict the digestibility of nutrients for monogastric animals in vitro. A selection is described in the following text.

A simple approach is based on the assumption that the solubility of CP in different media, like water, $\mathrm{NaCl}$, or $\mathrm{KOH}$, is related to its digestibility. This method is usually applied to examine the success of a heat treatment, for example in soybeans. A lesser solubility of samples indicates protein destruction and, therefore, a decreased digestibility of the CP, while an increased solubility can indicate an increased digestibility (Parsons et al. 1991, Carbonaro et al. 1997, Pastuszewska et al. 2003). 
There are two methods, which are based on an assumed correlation between the initial rate of peptide release and protein digestibility. Since cleaved peptide bonds release protons during proteolysis, the $\mathrm{pH}$ in a suspension declines. The $\mathrm{pH}$-drop method measures the decrease in $\mathrm{pH}$, while the $\mathrm{pH}$-stat method measures the amount of $\mathrm{NaOH}$, which is needed to keep $\mathrm{pH}$ constant (Hsu et al. 1977). In particular the $\mathrm{pH}$-stat method seems to be valid, reliable, and repeatable to predict protein digestibility of highly digestible proteins in pigs (Boisen \& Eggum 1991).

The dialysis cell method considers that end-products of digestion can supress enzyme activity (Gauthier et al. 1986, Savoie \& Gauthier 1986). Since low-molecular-weight products are continuously removed by dialyses during a pepsin-pancreatin digestion, an end-product inhibition is prevented and affecting factors can be studied. Furthermore, protein degradation in the small intestine as well as AA availability can be predicted (Galibois et al. 1989). However, the procedure is time-consuming and needs complex equipment. Similarly, computer-controlled systems to simulate the digestive tract of animals or humans were introduced by Minekus et al. (1995) and Wickham et al. (2009). Those complex systems require maintenance and are expensive. Therefore, they do not meet the requirements for a simple and cheap assay.

Furthermore, there are filtration methods to predict nutrient digestibility. Feed samples are incubated with enzymes. The insoluble residue is filtrated (or centrifuged) and analysed for residual $\mathrm{CP}$ and/or AA. Since in vitro solubility is expected to be correlated with in vivo digestibility, a prediction of the digestibility is possible. Studies have compared the in vitro rate of CP disappearance with the total tract digestibility of CP. However, since no microbial digestion of the hindgut is simulated, it can be expected that a better correlation can be reached in a comparison with the pc digestibility of CP. One-, two-, or multi-enzyme systems can be performed. One-step methods with only one enzyme (for example pepsin or pronase, Büchmann 1979a, Rochell et al. 2013) can be misleading since enzymes are highly specific (Sibbald 1987). The incubation in intestinal fluids (duodenal fluid, ileal fluid, or faeces extract) is a multi-enzyme method with only one step (Goering \& Van Soest 1970, Ehle et al. 1982, Löwgren et al. 1989). There are two-step multi-enzyme methods, where incubation with pepsin is followed by incubation for example with trypsin (Saunders et al. 1973), jejunal fluid (Furuya et al. 1979, Clunies \& Leeson 1984), or pancreatin (Büchmann 1979a, Asp et al. 1983, Boisen \& Fernández 1991). Boisen \& Fernández $(1991,1995)$ and Boisen (2007a) invented a multi-enzyme method to determine the digestibility of different nutrients for swine. The assay of Boisen \& Fernández (1995) was used in various studies to predict the standardised digestibility of CP and AA for pigs. Good correlations between the in vitro rate of disappearance with the apparent ileal digestibility of CP and AA in broiler chicken were also reported (de Coca-Sinova et al. 2008). These findings suggest that the 
multi-enzyme assay of Boisen \& Fernández (1995) is a promising and simple in vitro approach. Therefore, it was part of the present study.

Besides the $\mathrm{CN}$ and the $\mathrm{AA}$ other nutrients are important in animal feeding. It is, for example, possible that $B$ vitamin deficiencies of mixed feeds occur, when $B$ vitamin contents are not well regarded in ration formulation.

\section{B vitamins: Thiamine (vitamin $B_{1}$ ) and riboflavin (vitamin $B_{2}$ )}

$B$ vitamins are water-soluble vitamins. They are numbered in the order of their discovery. The first two B vitamins, thiamine and riboflavin, are considered in this work. Thiamine and riboflavin are continuously excreted in the urine of healthy individuals. Although animals continuously require a supply of B vitamins, they are not capable of synthesising these vitamins themselves (Squires 2011). In contrast, bacteria, plants, and fungi are capable of synthesising thiamine (Webb et al. 2007, Begley et al. 2008) and riboflavin (Bacher et al. 2000, Kemter 2002). B vitamins are also synthesised by some hindgut bacteria (Coates et al. 1968). However, the produced amounts are insufficient and not readily available for poultry and swine. Since the small intestine is the main site of absorption of thiamine and riboflavin, the majority of $B$ vitamins that are synthesised by hindgut bacteria is excreted with the faeces. Thus, thiamine and riboflavin are primarily available for animals that practice coprophagy (Luckey et al. 1955). Therefore, they are dietary essential nutrients and must be supplied with the diet. Excess of thiamine and riboflavin in feedstuff is not a cause for concern since no negative consequences have been observed (Bates 2007, Rivlin 2007). However, since thiamine and riboflavin deficiencies can lead to severe health problems and decreased performance, they are often supplemented in feedstuffs to ensure a sufficient supply. Although a general supplementation is declared, information on the contained amount of specific B vitamins in mixed feed is often lacking. Even in organic farming, their application is allowed to prevent deficiencies.

Thiamine supplements are commonly produced via chemical synthesis (Revuelta et al. 2016). Although riboflavin can be produced using chemical synthesis, it is currently obtained mostly using biotechnological approaches that involve different microorganisms (Schwechheimer et al. 2016, Revuelta et al. 2017). These supplements are used regularly in feedstuffs for farm animals in conventional and organic farming in amounts that ensure a sufficient supply. 


\section{Objectives}

The aim of the study was to characterise organically cultivated cereals and grain legumes as commonly used feedstuffs for monogastric animals. Emphasis was laid on the contents of the crude nutrients, amino acids, thiamine, and riboflavin as well as on the precaecal digestibility of the crude protein and amino acids for broiler chicken. The gathered information can be helpful in achieving $100 \%$ organic feeding.

The following questions were posed:

1. How can the nutrient composition of organically produced cereals and grain legumes be described and to what extent does the nutrient composition of organically cultivated cereals and grain legumes vary?

2. Is it possible to predict amino acid contents of organically cultivated cereals and grain legumes from crude protein content using equations?

3. What effect do the variety and the environmental conditions have on the nutrient contents of organically cultivated cereal grains and grain legumes?

4. What amount of crude protein and amino acids of commonly used field peas and field beans in organic farming is digestible at the terminal ileum of young broiler chicken?

5. Is it possible to use an adapted multi-enzyme-method to compare the precaecal digestibility of crude protein and amino acids in single feedstuffs for broiler chicken?

6. What effect do the variety and the environmental conditions have on the in vitro digestibility of crude protein and amino acids of cereals and grain legumes? 


\section{References - General Introduction}

Adedokun, S.A., Jaynes, P., El-Hack, M.E.A., Payne, R.L. and Applegate, T.J. (2014). Standardized Ileal Amino Acid Digestibility of Meat and Bone Meal and Soybean Meal in Laying Hens and Broilers. Poult Sci 93, 420-428. DOI: 10.3382/ps.2013-03495

Agroscope (2011-2016). Feedbase - the Swiss Feed Database, https://www.feedbase.ch/, University of Zurich, Agroscope. Last Access 25th of June 2018.

Ajinomoto Animal Nutrition Group (2003-2013). Ajinomoto Heartland (since April 2018 Ajinomoto Animal Nutrition North America) Amino Acid Database, http://aaa.lysine.com/, Last Access 25th June 2018.

Asp, N.G., Johansson, C.G., Hallmer, H. and Siljestroem, M. (1983). Rapid Enzymic Assay of Insoluble and Soluble Dietary Fiber. J Agric Food Chem 31, 476-482. DOI: 10.1021/jf00117a003

Bacher, A., Eberhardt, S., Fischer, M., Kis, K. and Richter, G. (2000). Biosynthesis of Vitamin B2 (Riboflavin). Ann Rev Nutr 20, 153-167. DOI: 10.1146/annurev.nutr.20.1.153

Bachteler, K. (2015). Sojabohnen mit Streifen-Schnelltests auf Gentechnik prüfen?, Taifun Sojainfo.

Baker, D.H. (2003). Ideal Dietary Amino Acid Patterns for Broiler Chickens, In: D'Mello (Ed.), Amino Acids in Animal Nutrition, CABI Publishing, Wallingford, pp. 223-235.

Baker, D.H., Batal, A.B., Parr, T.M., Augspurger, N.R. and Parsons, C.M. (2002). Ideal Ratio (Relative to Lysine) of Tryptophan, Threonine, Isoleucine, and Valine for Chicks During the Second and Third Weeks Posthatch. Poult Sci 81. DOI: 10.1093/ps/81.4.485

Barnes, E.M. (1979). The Intestinal Microflora of Poultry and Game Birds During Life and after Storage. J Appl Bacteriol 46, 407-419. DOI: 10.1111/j.1365-2672.1979.tb00838.x

Batal, A.B. and Parsons, C.M. (2002). Effects of Age on Nutrient Digestibility in Chicks Fed Different Diets. Poult Sci 81, 400-407. DOI: 10.1093/ps/81.3.400

Bates, C.J. (2007). Chapter 8: Thiamine, In: Zempleni, J., Rucker, R.B., McCormick, D.B. and Suttie, J.W. (Eds.), Handbook of Vitamins, CRC Press, Taylor \& Francis Group, pp. 253 - 288. ISBN-10: 0-8493-4022-5

Baumann, W. (2004). Biofutterrationen für Aufzucht- und Legehennen [Organic Diets for Rearing and Laying Hens], Internationale Geflügeltagung, Gerolfingen, Germany.

Bedford, M., Classen, H.L. and Campbell, G.L. (1991). The Effect of Pelleting, Salt, and Pentosanase on the Viscosity of Intestinal Contents and the Performance of Broilers Fed Rye. Poult Sci 70, 1571-1577.

Begley, T.P., Chatterjee, A., Hanes, J.W., Hazra, A. and Ealick, S.E. (2008). Cofactor Biosynthesis-Still Yielding Fascinating New Biological Chemistry. Curr Opin Chem Biol 12, 118-125. DOI: 10.1016/j.cbpa.2008.02.006

Bellof, G. and Schmidt, E. (2007). Ökologische Geflügelmast - Lösungsmöglichkeiten für eine 100 \% BioFütterung [Poultry Fattening in Orgainc Farming - Possible Solutions for 100\% Organic Feeding], Schriftenreihe der Bayerischen Landesanstalt für Landwirtschaft (LfL) - Angewandte Forschung und Beratung für den ökologischen Landbau in Bayern, Wiesinger, K., Freising, pp. 23-33.

Berk, A. and Weißmann, F. (2012). Can Compensatory Growth Contribute to Reduce the So-Called Protein Gap in Organic Pig Fattening? Landbauforschung - vTI Agriculture and Forestry Research 3, 117-128.

Blumenthal, C., Bekes, F., Batey, I., Wrigley, C., Moss, H., Mares, D. and Barlow, E. (1991). Interpretation of Grain Quality Results from Wheat Variety Trials with Reference to High Temperature Stress. Aust J Agric Res 42, 325-334. DOI: 10.1071/AR9910325

Boisen, S. (2007a). In Vitro Analyses for Predicting Standardised Ileal Digestibility of Protein and Amino Acids in Actual Batches of Feedstuffs and Diets for Pigs. Livest Sci 109, 182-185. DOI 10.1016/j.livsci.2007.01.141

Boisen, S. (2007b). A New Concept for Practical Feed Evaluation Systems. Faculty of Agricultural Sciences, University of Aarhus, Tjele. ISBN 87-91949-18-1

Boisen, S., Agergaard, N., Rotenberg, S. and Kragelund, Z. (1985). Effects of Gut Flora on Intestinal Activities of Trypsin, Chymotrypsin, Elastase and Amylase in Growing Rats Fed Purified Diets with Cellulose, Pectin or Sand. Zeitschrift für Tierphysiologie Tierernährung und Futtermittelkunde 53, 245-254. DOI: $10.1111 / \mathrm{j} .1439-0396.1985 . t b 00029 . x$

Boisen, S. and Eggum, B.O. (1991). Critical Evaluation of in Vitro Methods for Estimating Digestibility in SimpleStomach Animals. Nutr Res Reviews 4, 141-162. DOI: 10.1079/NRR19910012

Boisen, S. and Fernández, J.A. (1991). In Vitro Digestibility of Energy and Amino Acids in Pig Feeds, In: Verstegen, M.W.A., Huisman, J. and Den Hartog, L.A. (Eds.), Symposium on Digestive Physiology in Pigs, Pudoc Wageningen EAAP, Wageningen Doorwerth, Netherlands.

Boisen, S. and Fernández, J.A. (1995). Prediction of the Apparent lleal Digestibility of Protein and Amino Acids in Feedstuffs and Feed Mixtures for Pigs by in Vitro Analyses. Anim Feed Sci Tech 51, 29-43. DOI: 10.1016/0377-8401(94)00686-4 
Bryden, W.L., Li, X., Ravindran, G., Hew, L.I. and Ravindran, V. (2009). Ileal Digestible Amino Acid Values in Feedstuffs for Poultry. Rural Industries Research and Development Corporation. ISBN: 1741518709

Büchmann, N.B. (1979a). In Vitro Digestibility of Protein from Barley and Other Cereals. J Sci Food Agr 30, 583589. DOI: $10.1002 /$ jsfa.2740300606

Burhol, P.G. (1982). Regulation of Gastric Secretion in the Chicken. Scand J Gastroent 17, $321-323$. DOI: 10.3109/00365528209182061

Butts, C.A., Monro, J.A. and Moughan, P.J. (2012). In Vitro Determination of Dietary Protein and Amino Acid Digestibility for Humans. Br J Nutr 108, S282-S287. DOI:10.1017/S0007114512002310

Canbolat, O., Tamer, E. and Acikgoz, E. (2007). Chemical Composition, Metabolizable Energy and Digestibility in Pea Seeds of Differing Testa and Flower Colors. J Biol Environ Sci 1, 59-65.

Canh, T.T., Aarnink, A.J.A., Schutte, J.B., Sutton, A., Langhout, D.J. and Verstegen, M.W.A. (1998). Dietary Protein Affects Nitrogen Excretion and Ammonia Emission from Slurry of Growing-Finishing Pigs. Livest Prod Sci 56, 181-191. DOI: 10.1016/S0301-6226(98)00156-0

Carbonaro, M., Cappelloni, M., Nicoli, S., Lucarini, M. and Carnovale, E. (1997). Solubility-Digestibility Relationship of Legume Proteins. J Agr Food Chem 45, 3387-3394. DOI: 10.1021/Jf970070y

Chalova, V.I., Kim, J., Patterson, P.H., Ricke, S.C. and Kim, W.K. (2016). Reduction of Nitrogen Excretion and Emission in Poultry: A Review for Organic Poultry. J Environ Sci Health, Part B 51, 230-235. DOI: $10.1080 / 03601234.2015 .1120616$

Champ, M., Szylit, O., Raibaud, P. and Aïut-Abdelkader, N. (1983). Amylase Production by Three Lactobacillus Strains Isolated from Chicken Crop. J Appl Bacteriol 55, 487-493. DOI: 10.1111/j.1365-2672.1983.tb01689.x

Chung, T.K. and Baker, D.H. (1992). Ideal Amino Acid Pattern for 10-Kilogram Pigs. Anim Sci 70, 3102-3111. DOI: $10.2527 / 1992.70103102 x$

Clunies, M. and Leeson, S. (1984). In Vitro Estimation of Dry Matter and Crude Protein Digestibility. Poult Sci 63, 89-96. DOI: 10.3382/ps.0630089

Coates, M.E., Ford, J.E. and Harrison, G.F. (1968). Intestinal Synthesis of Vitamins of the B Complex in Chicks. Br J Nutr 22, 493-500. DOI: 10.1079/BJN19680057

Cremers, S. (2002). Untersuchungen Zur Scheinbaren Und Wahren Ilealen Protein- Und Aminosäurenverdaulichkeit Von Fleisch-Knochen-Mehlen Beim Wachsenden Huhn Und Methodenvergleich Zur Bestimmung Der Endogenen Aminosäurenverluste, University of Gießen.

Dalibard, P. and Paillard, E. (1995). Use of the Digestible Amino Acid Concept in Formulating Diets for Poultry. Anim Feed Sci Tech 53, 189-204. DOI: 10.1016/0377-8401(95)02010-W

de Coca-Sinova, A., Valencia, D.G., Jiménez-Moreno, E., Lázaro, R. and Mateos, G.G. (2008). Apparent lleal Digestibility of Energy, Nitrogen, and Amino Acids of Soybean Meals of Different Origin in Broilers. Poult Sci 87, 2613-2623. DOI: 10.3382/ps.2008-00182

Denbow, D.M. (2015). Chapter 14 - Gastrointestinal Anatomy and Physiology A2 - Scanes, Colin G, In: Whittow, G.C. (Ed.), Sturkie's Avian Physiology (Sixth Edition), Academic Press, San Diego, pp. 337-366. 9780-12-747605-6

DLG (2006-2010). DLG-Datenbank Futtermittel [DLG-Database for Feedstuffs], Deutsche LandwirtschaftsGesellschaft e.V. http://datenbank.futtermittel.net, last access 11th July 2018.

DLG (2014). Dlg-Futterwerttabellen Schwein [Dlg-Feed Value Tables for Swine]. DLG-Verlag.

Doeschate, R.A.H.M.T., Scheele, C.W., Schreurs, V.V.A.M. and Van Der Klis, J.D. (1993). Digestibility Studies in Broiler Chickens: Influence of Genotype, Age, Sex and Method of Determination. Br Poult Sci 34, 131-146. DOI: $10.1080 / 00071669308417569$

Donkoh, A. and Moughan, P.J. (1999). Endogenous lleal Nitrogen and Amino Acid Flows in the Growing Pig Receiving a Protein-Free Diet and Diets Containing Enzymically Hydrolysed Casein or Graded Levels of Meat and Bone Meal. Anim Sci 68, 511-518. DOI: 10.1017/S1357729800050530

Eggum, B.O. and Boisen, S. (1991). In Vitro Techniques of Measuring Digestion, In: Verstegen, M.W.A., Huisman, J. and Den Hartog, L.A. (Eds.), Digestive Physiology of Pigs, Wageningen, pp. 213-225.

Eggum, B.O., Hansen, I. and Larsen, T. (1989). Protein Quality and Digestible Energy of Selected Foods Determined in Balance Trials with Rats. Plant Food Hum Nutr 39, 13-21. DOI: 10.1007/bf01092397

Ehle, F.R., Jeraci, J.L., Robertson, J.B. and Van Soest, P.J. (1982). The Influence of Dietary Fiber on Digestibility, Rate of Passage and Gastrointestinal Fermentation in Pigs. J Anim Sci 55, 1071-1081. DOI: $10.2527 /$ jas $1982.5551071 \mathrm{x}$

Elbers, A.R.W., Den Hartog, L.A., Verstegen, M.W.A. and Zandstra, T. (1989). Between- and within-Herd Variation in the Digestibility of Feed for Growing-Finishing Pigs. Livest Prod Sci 23, 183-193. DOI: 10.1016/0301-6226(89)90013-4 
Elwinger, K., Tufvesson, M., Lagerkvist, G. and Tauson, R. (2008). Feeding Layers of Different Genotypes in Organic Feed Environments. Br Poult Sci 49, 654-665. DOI: 10.1080/00071660802491519

Engberg, R.M., Hedemann, M.S. und Jensen, B.B. (2002) The influence of grinding and pelleting of feed on the microbial composition and activity in the digestive tract of broiler chickens. Br Poult Sci 43:4; 569-579, DOI: $10.1080 / 0007166022000004480$

Eriksson, M., Waldenstedt, L., Engström, B. and Elwinger, K. (2009). Protein Supply in Organic Broiler Diets. Acta Agr Scand a-An 59, 211-219. DOI: 10.1080/09064700903358256

Eurostat (2018). Organic Production of Animal Products (from 2012 Onwards) and Organic Livestock of Animals (from 2012 Onwards), https://ec.europa.eu/eurostat/data/database, Last Access 26th of June 2018.

Evonik (2016). Evonik Nutrition \& Care Gmbh. Aminodat 5.0, Version 1.03.

Fahmy, A.S., Ali, A.A. and Mohamed, S.A. (2004). Characterization of a Cysteine Protease from Wheat Triticum Aestivum (Cv. Giza 164). Biores Technol 91, 297-304. DOI: 10.1016/S0960-8524(03)00193-7

Farner, D.S. (1942b). The Hydrogen Ion Concentration in Avian Digestive Tracts. Poult Sci 21, 445-450. DOI: $10.3382 /$ ps.0210445

Farner, D.S. (1943). The Effect of Certain Dietary Factors on Gastric Hydrogen Ion Concentration and Acidity in the Domestic Fowl. Poult Sci 22, 295-298. DOI: 10.3382/ps.0220295

Francis, T.R. and Kannenberg, L.W. (1978). Yield Stability Studies in Short-Season Maize. I. A Descriptive Method for Grouping Genotypes. Can J Plant Sci 58, 1029-1034. DOI: 10.4141/cjps78-157

Fuller, M.F. (2004). The Encyclopedia of Farm Animal Nutrition. CABI. ISBN: 0851993699

Fuller, M.F., Darcy-Vrillon, B., Laplace, J.P., Picard, M., Cadenhead, A., Jung, J., Brown, D. and Franklin, M.F. (1994). The Measurement of Dietary Amino Acid Digestibility in Pigs, Rats and Chickens: A Comparison of Methodologies. Anim Feed Sci Tech 48, 305-324. DOI: 10.1016/0377-8401(94)90180-5

Furuya, S., Sakamoto, K. and Takahashi, S. (1979). A New in Vitro Method for the Estimation of Digestibility Using the Intestinal Fluid of the Pig. Br J Nutr 41, 511-520. DOI: 10.1079/BJN19790066

Galibois, I., Savoie, L., Simoes Nunes, C. and Rérat, A. (1989). Relation between in Vitro and in Vivo Assessment of Amino Acid Availability. Reprod Nutr Dev 29, 495-507.

Gauthier, S.F., Vachon, C. and Savoie, L. (1986). Enzymatic Conditions of an in Vitro Method to Study Protein Digestion. J Food Sci 51, 960-964. DOI: 10.1111/j.1365-2621.1986.tb11208.x

GfE (1999). Empfehlungen Zur Energie- und Nährstoffversorgung der Legehennen und Masthühner (Broiler) [Recommendations for the Energy and Nutrient Supply for Layers and Broilers]. DLG Verlag, Frankfurt a. M., Germany.

GfE (2006). Empfehlungen Zur Energie- und Nährstoffversorgung von Schweinen [Recommendations for the Energy and Nutrient Supply for Swine]. DLG Verlag, Frankfurt a. M., Germany.

Goering, H.K. and Van Soest, P.J. (1970). Forage Fiber Analyses (Apparatus, Reagents, Procedures, and Some Applications). Agriculture Handbook, No. 379. Washington DC: Agricultural Research Service, US Department of Agriculture.

Harvey, B.M.R. and Oaks, A. (1974). Characteristics of an Acid Protease from Maize Endosperm. Plant Phsiol 53, 449-452. DOI: 10.1104/pp.53.3.449

Hejdysz, M., Kaczmarek, S.A. and Rutkowski, A. (2016). Extrusion Cooking Improves the Metabolisable Energy of Faba Beans and the Amino Acid Digestibility in Broilers. Anim Feed Sci Tech 212, 100-111. DOI: 10.1016/j.anifeedsci.2015.12.008

Heo, J.M., Kim, J.C., Hansen, C.F., Mullan, B.P., Hampson, D.J. and Pluske, J.R. (2009). Feeding a Diet with Decreased Protein Content Reduces Indices of Protein Fermentation and the Incidence of Postweaning Diarrhea in Weaned Pigs Challenged with an Enterotoxigenic Strain of Escherichia Coli1. J Anim Sci 87, 2833-2843. DOI: 10.2527/jas.2008-1274

Herpol, C. (1966). Influence De L'age Sur Le Ph Dans Le Tube Digestif De Gallus Domesticus [Does Age Influence the $\mathrm{Ph}$ in the Digestive Tract of Gallus Domesticus?]. Ann Biol Anim Biochem Biophys 6 , 495-502.

Hess, V. and Lemme, A. (2018). Arguments Supporting the Use of Standardised Ileal Amino Acid Digestibility in Broilers. In EPC 2006-12th European Poultry Conference, Verona, Italy, 10-14 September, 2006. World's Poultry Science Association (WPSA).

Hesselman, K. und Åman, P. (1986) The effect of beta-glucanase on the utilization of starch and nitrogen by broiler chickens fed on barley of low or high-viscosity. Anim Feed Sci Tech 15, 83-93.

Hetland, H. und Svihus, B. (2001) Effect of oat hulls on performance, gut capacity and feed passage time in broiler chickens. Br Poult Sci 42:3, 354-361, DOI: 10.1080/00071660120055331 
Hinton, J.A., Buhr, R.J. and Ingram, K.D. (2000). Physical, Chemical, and Microbiological Changes in the Crop of Broiler Chickens Subjected to Incremental Feed Withdrawal. Poult Sci 79, 212-218. DOI: $10.1093 / \mathrm{ps} / 79.2 .212$

Hovi, M., Sundrum, A. and Thamsborg, S.M. (2003). Animal Health and Welfare in Organic Livestock Production in Europe: Current State and Future Challenges. Livest Prod Sci 80, 41-53. DOI: 10.1016/S0301-6226(02)00320-2

Hsu, H.W., Vavak, D.L., Satterlee, L.D. and Miller, G.A. (1977). A Multienzyme Technique for Estimating Protein Digestibility. J Food Sci 42, 1269-1273. DOI: 10.1111/j.1365-2621.1977.tb14476.x

Ikeda, M. (2003). Amino Acid Production Processes, In: Faurie, R., Thommel, J., Bathe, B., Debabov, V.G., Huebner, S., Ikeda, M., Kimura, E., Marx, A., Möckel, B., Mueller, U. and Pfefferle, W. (Eds.), Microbial Production of L-Amino Acids, Springer Berlin Heidelberg, Berlin, Heidelberg, pp. 1-35. DOI: 10.1007/3540-45989-8_1

INRA-CIRAD-AFZ (2018). INRA-CIRAD-AFZ Feed Tables - Composition and Nutritive Values of Feeds for Cattle, Sheep, Goats, Pigs, Poultry, Rabbits, Horses and Salmonids, https://feedtables.com/, Last Access 1st August 2018.

Jansman, A.J.M., Smink, W., van Leeuwen, P. and Rademacher, M. (2002). Evaluation through Literature Data of the Amount and Amino Acid Composition of Basal Endogenous Crude Protein at the Terminal Ileum of Pigs. Anim Feed Sci Tech 98, 49-60. DOI: 10.1016/S0377-8401(02)00015-9

Jeroch, H., Simon, A. and Zentek, J. (2012). Geflügelernährung [Poultry Nutrition]. Ulmer. ISBN: 978-3-80017869-8

Jiménez-Moreno, E., González-Alvarado, J.M., de Coca-Sinova, A., Lázaro, R. and Mateos, G.G. (2009). Effects of Source of Fibre on the Development and Ph of the Gastrointestinal Tract of Broilers. Anim Feed Sci Tech 154, 93-101. DOI: 10.1016/j.anifeedsci.2009.06.020

Johns, D.C., Low, C.K. and James, K.A.C. (1986). Comparison of Amino Acid Digestibility Using the lleal Digesta from Growing Chickens and Cannulated Adult Cockerels. Br Poult Sci 27, 679-685. DOI: 10.1080/00071668608416927

Jongbloed, A.W. and Lenis, N.P. (1992). Alteration of Nutrition as a Means to Reduce Environmental Pollution by Pigs. Livest Prod Sci 31, 75-94. DOI: 10.1016/0301-6226(92)90057-B

Joost Meyer zu Bakum, R. (2004). Futter Selber Erzeugen Und Mischen [Produce and Mix Feedstuffs Yourself], International Poultry Conference, Gerolfingen, Germany.

Józefiak, D., Rutkowski, A., Jensen, B.B. and Engberg, R.M. (2007). Effects of Dietary Inclusion of Triticale, Rye and Wheat and Xylanase Supplementation on Growth Performance of Broiler Chickens and Fermentation in the Gastrointestinal Tract. Anim Feed Sci Tech 132, 79-93. DOI: 10.1016/j.anifeedsci.2006.03.011

Kadim, I.T. and Moughan, P.J. (1997). Development of an Ileal Amino Acid Digestibility Assay for the Growing Chicken-Effects of Time after Feeding and Site of Sampling. Br Poult Sci 38, 89-95. DOI: $10.1080 / 00071669708417946$

Kadim, I.T., Moughan, P.J. and Ravindran, V. (2002). Ileal Amino Acid Digestibility Assay for the Growing Meat Chicken--Comparison of Ileal and Excreta Amino Acid Digestibility in the Chicken. Br Poult Sci 43, 588597. DOI: $10.1080 / 0007166022000004507$

Karakas, P., Versteegh, H.A.J., van der Honing, Y., Kogut, J. and Jongbloed, A.W. (2001). Nutritive Value of the Meat and Bone Meals from Cattle or Pigs in Broiler Diets. Poult Sci 80, 1180-1189. DOI: $10.1093 / p s / 80.8 .1180$

Kemter, K. (2002). Untersuchungen Zur Riboflavin Synthase Und Flavokinase Aus Verschiedenen Organismen [Studies on Riboflavin Synthase and Flavokinase from Different Organisms]. Dissertation, University of Munich, Universität München.

Khush, G.S. (1995). Modern Varieties - Their Real Contribution to Food Supply and Equity. GeoJournal 35, 275-284. DOI: 10.1007/BF00989135

Kim, E.J., Utterback, P.L. and Parsons, C.M. (2011b). Development of a Precision-Fed lleal Amino Acid Digestibility Assay Using 3-Week-Old Broiler Chicks. Poult Sci 90, 396-401. DOI: $10.3382 / p s .2010-01088$

Kjaer, J.B. and Sørensen, P. (2002). Feather Pecking and Cannibalism in Free-Range Laying Hens as Affected by Genotype, Dietary Level of Methionine + Cystine, Light Intensity During Rearing and Age at First Access to the Range Area. Appl Anim Behav Sci 76, 21-39. DOI: 10.1016/S0168-1591(01)00209-X

Kluth, H., Fricke, M. and Rodehutscord, M. (2009). Precaecal Amino Acid Digestibility of Different Wheat Cultivars in Broilers. Arch Geflugelk 73, 80-86. ISSN 0003-9098

Kluth, H., Mantei, M., Elwert, C. and Rodehutscord, M. (2005a). Variation in Precaecal Amino Acid and Energy Digestibility between Pea (Pisum Sativum) Cultivars Determined Using a Linear Regression Approach. Br Poult Sci 46, 325-332. DOI: 10.1080/00071660500127415 
Kluth, H., Mehlhorn, K. and Rodehutscord, M. (2005b). Studies on the Intestine Section to Be Sampled in Broiler Studies on Precaecal Amino Acid Digestibility. Arch Anim Nutr 59, 271-279. DOI: $10.1080 / 17450390500217058$

Kluth, H. and Rodehutscord, M. (2009). Standardisierte Futterbewertung auf der Basis der Aminosäurenverdaulichkeit beim Geflügel [Standardised Feed Evaluation on the Basis of the Amino Acid Digestibility in Poultry]. Uebers Tierern 37, 1.26.

Kokas, E., Kaufman, S.H. and Long, J.C. (1971). Effect of Glucagon on Gastric and Duodenal Secretion in Chickens. Z Vergl Physiol 74, 315-325. DOI: 10.1007/bf00297731

Kokue, E.-i. and Hayama, T. (1972). Effects of Starvation and Feeding on the Exocrine Pancreas of the Chicken. Poult Sci 51, 1366-1370. DOI: 10.3382/ps.0511366

Kokue, E.-i. and Hayama, T. (1976). The Endogenous Secretin in Chicken: Minor Physiological Role in Exocrine Pancreatic Secretion. Jap J Physiol 26, 1-8. DOI: 10.2170/jjphysiol.26.1

Le Bellego, L. and Noblet, J. (2002). Performance and Utilization of Dietary Energy and Amino Acids in Piglets Fed Low Protein Diets. Livest Prod Sci 76, 45-58. DOI: 10.1016/S0301-6226(02)00008-8

Liu, S.Y., Selle, P.H., Khoddami, A., Roberts, T.H. and Cowieson, A.J. (2014). Graded Inclusions of Sodium Metabisulphite in Sorghum-Based Diets: li. Modification of Starch Pasting Properties in Vitro and Beneficial Impacts on Starch Digestion Dynamics in Broiler Chickens. Anim Feed Sci Tech 190, 6878. DOI: 10.1016/j.anifeedsci.2013.12.016

Long, J.F. (1967). Gastric Secretion in Unanesthetized Chickens. Am J Physiol 212, 1303-1307. DOI: 10.1152/ajplegacy.1967.212.6.1303

Löwgren, W., Graham, H. and Åman, P. (1989). An in Vitro Method for Studying Digestion in the Pig. Br J Nutr 61, 673-687. DOI:10.1079/BJN19890154

Luckey, T.D., Pleasants, J.R. and Reyniers, J.A. (1955). Germfree Chicken Nutrition li. Vitamin Interrelationships: Two Figures. J Nutr 55. DOI: 10.1093/jn/55.1.105

Mabelebele, M., Alabi, O.J., Ng'ambi, J.W., Norris, D. and Ginindza, M.M. (2014). Comparison of Gastrointestinal Tracts and Ph Values of Digestive Organs of Ross 308 Broiler and Indigenous Venda Chicken Fed the Same Diet. Asian J Anim Vet Adv 9, 71-76. DOI: 10.3923/ajava.2014.71.76

Mack, S., Bercovici, D., De Groote, G., Leclercq, B., Lippens, M., Pack, M., Schutte, J.B. and Van Cauwenberghe, S. (1999). Ideal Amino Acid Profile and Dietary Lysine Specification for Broiler Chickens of 20 to 40 Days of Age. Br Poult Sci 40, 257-265. DOI: 10.1080/00071669987683

Mason, V.C. (1984). Metabolism of Nitrogenous Compounds in the Large Gut. Proc Nutr Soc 43, 45-53. DOI:10.1079/PNS19840026

Matthews, D.M. (1972). Intestinal Absorption of Amino Acids and Peptides. Proc Nutr Soc 31, 171-177. DOI: $10.1079 / P N S 19720033$

Mehanso, H., Butler, L.G. and Carlson, D.M. (1987). Dietary Tannins and Salivary Proline-Rich Proteins: Interactions, Induction, and Defense Mechanisms. Ann Rev Nutr 7, 423-440.

Mehner, A. and Hartfield, W. (1983). Handbuch Der Geflügelphysiologie, Teil li [Handbook of Avian Physiology, Part li]. Karger. ISBN: 3-8055-3738-7

Minekus, M., Marteau, P., Havenaar, R. and Huis in 't Veld, J.H.J. (1995). A Multicompartmental Dynamic Computer-Controlled Model Simulating the Stomach and Small-Intestine. Altern Lab Anim 23, 197209. ISSN: 0261-1929

Moewius, J., Röhrig, P., Schaack, D., Rampold, C., Brzukalla, H.-J., Gottwald, F., Stein-Bachinger, K., Wolter, M. and Sanders, J. (2018). Zahlen - Daten - Fakten - Die Bio-Branche 2018, BOELW (Bund Ökologische Lebensmittelwirtschaft e. V.), Berlin, Germany.

Moretó, M. and Planas, J.M. (1989). Sugar and Amino Acid Transport Properties of the Chicken Ceca. J Exp Zool 252, 111-116. DOI: 10.1002/jez.1402520518

Morita, S., Fukase, M., Hoshino, K., Fukuda, Y., Yamaguchi, M. and Morita, Y. (1994). A Serine Protease in Soybean Seeds That Acts Specifically on the Native A Subunit of B-Conglycinin. Plant Cell Physiol 35, 1049-1056. DOI: 10.1093/oxfordjournals.pcp.a078693

Nagaraj, M. (2006). Evaluation of Nutrition and Management Factors Inthe Etiology of Pododermatitis in Broiler Chickens. Master's Thesis, Auburn University.

NRC (1994). (National Research Council) Nutrient Requirements of Poultry, 9th Revised Edition, In: Nutrition, S.o.P., Nutrition, C.o.A. and Council, N.R. (Eds.), National Academie Press, Washington DC, Washington D.C.

NRC (2012). (National Research Council) Nutrient Requirements of Swine, 11th Revised Edition. The National Academies Press, Washington DC. ISBN: 9780309059930 
Oviedo-Rondón, E.O., Ferket, P.R. and Havestein, G.B. (2006). Nutritional Factors That Affect Leg Problems in Broilers and Turkeys. Avian and Poultry Biology Reviews 17, 89-103. DOI: 10.3184/147020606783437921

Pang, Y. and Applegate, T.J. (2007). Effects of Dietary Copper Supplementation and Copper Source on Digesta $\mathrm{Ph}$, Calcium, Zinc, and Copper Complex Size in the Gastrointestinal Tract of the Broiler Chicken. Poult Sci 86, 531-537. DOI: 10.1093/ps/86.3.531

Parsons, C.M. (1985). Influence of Caecectomy on Digestibility of Amino Acids by Roosters Fed Distillers' Dried Grains with Solubles. J Agric Sci 104, 469-472. DOI:10.1017/S0021859600044178

Parsons, C.M., Hashimoto, K., Wedekind, K.J. and Baker, D.H. (1991). Soybean Protein Solubility in Potassium Hydroxide: An in Vitro Test of in Vivo Protein Quality. Anim Sci 69, 2918-2924. DOI: $10.2527 / 1991.6972918 x$

Pastuszewska, B., Jablecki, G., Buraczewska, L., Dakowski, P., Taciak, M., Matyjek, R. and Ochtabinska, A. (2003). The Protein Value of Differently Processed Rapeseed Solvent Meal and Cake Assessed by in Vitro Methods and in Tests with Rats. Anim Feed Sci Tech 106, 175-188. DOI: 10.1016/s03778401(03)00005-1

Perttilä, S., Valaja, J., Partanen, K., Jalava, T. and Venäläinen, E. (2002). Apparent lleal Digestibility of Amino Acids in Protein Feedstuffs and Diet Formulation Based on Total Vs Digestible Lysine for Poultry. Anim Feed Sci Tech 98, 203-218. DOI: 10.1016/S0377-8401(02)00031-7

Pettersson, D., Graham, H. and Åman, P. (1991). The Nutritive Value for Broiler Chickens of Pelleting and Enzyme Supplementation of a Diet Containing Barley, Wheat and Rye. Anim Feed Sci Tech 33, 1-14. DOI: 10.1016/0377-8401(91)90041-P

Polak, J.M. and Bloom, S.R. (1982). Localization of Regulatory Peptides in the Gut. Br Med Bull 38, 303-308. DOI: 10.1093/oxfordjournals.bmb.a071777

Pubols, M.H. (1991). Ratio of Digestive Enzymes in the Chick Pancreas. Poult Sci 70, 337-342. DOI: $10.3382 / p s .0700337$

Pusztai, A. (1989). Biological Effects of Lectins, In: Huisman, J., Van der Poel, A.F.B. and Liener, I.E. (Eds.), Recent Advances of Research in Antinutritional Factors in Legume Seeds, Wageningen, Wageningen, pp. 17-29.

Ravindran, V. and Bryden, W.L. (1999). Amino Acid Availability in Poultry - in Vitro and in Vivo Measurements. Aust J Agric Res 50, 889-908. DOI: 10.1071/Ar98174

Ravindran, V. and Hendriks, W.H. (2004). Recovery and Composition of Endogenous Protein Collected at the Terminal lleum as Influenced by the Age of Broiler Chickens. Aust J Agric Res 55, 705-709. DOI: $10.1071 / \operatorname{Ar} 04008$

Ravindran, V., Hew, L.I., Ravindran, G. and Bryden, W.L. (1999). A Comparison of lleal Digesta and Excreta Analysis for the Determination of Amino Acid Digestibility in Food Ingredients for Poultry. Br Poult Sci 40, 266-274. DOI: 10.1080/00071669987692

Recoules, E., Sabboh-Jourdan, H., Narcy, A., Lessire, M., Harichaux, G., Labas, V., Duclos, M.J. and RéhaultGodbert, S. (2017). Exploring the in Vivo Digestion of Plant Proteins in Broiler Chickens. Poult Sci 96, 1735-1747. DOI: $10.3382 / p s / p e w 444$

Revuelta, J.L., Buey, R.M., Ledesma-Amaro, R. and Vandamme, E.J. (2016). Microbial Biotechnology for the Synthesis of (Pro)Vitamins, Biopigments and Antioxidants: Challenges and Opportunities. Microb Biotechnol 9, 564-567. DOI: 10.1111/1751-7915.12379

Revuelta, J.L., Ledesma-Amaro, R., Lozano-Martinez, P., Díaz-Fernández, D., Buey, R.M. and Jiménez, A. (2017). Bioproduction of Riboflavin: A Bright Yellow History. J Ind Microbiol Biot 44, 659-665. DOI: $10.1007 /$ s10295-016-1842-7

Richter, W., Werner, E., Bähr, H. and van den Weghe, H. (1992). Grundwerte der Tiergesundheit und Haltung [Basic Values of Animal Health and Husbandry]. 3rd Edition. Gustav Fischer Verlag Jena/Stuttgart. ISBN: 3-334-60384-9

Rivlin, R.S. (2007). Chapter 7: Riboflavin (Vitamin B2), In: Zempleni, J., Rucker, R.B., McCormick, D.B. and Suttie, J.W. (Eds.), Handbook of Vitamins, CRC Press, Taylor \& Francis Group, pp. 233 - 252. ISBN10: $0-8493-4022-5$

Rochell, S.J., Kuhlers, D.L. and Dozier, W.A. (2013). Relationship between in Vitro Assays and Standardized Ileal Amino Acid Digestibility of Animal Protein Meals in Broilers. Poult Sci 92, 158-170. DOI: $10.3382 / p s .2012-02365$

Rodehutscord, M., Kapocius, M., Timmler, R. and Dieckmann, A. (2004). Linear Regression Approach to Study Amino Acid Digestibility in Broiler Chickens. Br Poult Sci 45, 85-92. DOI: 10.1080/00071660410001668905

Rodehutscord, M. and Kluth, H. (2003). Aminosäurenverdaulichkeit als ein Futterwertkriterium in der Geflügelfütterung: Methodische Aspekte zur Messung [Amino Acid Digestibility as a Feed Value Criterion in Poultry Feeding: Methodological Aspects of Measurement], Lohmann Information, pp. 1-8. 
Saunders, R.M., Connor, M.A., Booth, A.N., Bickoff, E.M. and Kohler, G.O. (1973). Measurement of Digestibility of Alfalfa Protein Concentrates by in Vivo and in Vitro Methods. J Nutr 103, 530-535. DOI: $10.1093 / \mathrm{jn} / 103.4 .530$

Sauvant, D., Perez, J.-M., Tran, G., Bontems, V., Chapoutot, P., Doreau, B., Jeondreville, C., Kaushik, S.J., Lessire, M., Martin-Rosset, W., Meschy, F., Noblet, J., Peyraud, J.-L., Rulquin, H. and Sève, B. (2004). Tables of Composition and Nutritional Value of Feed Materials: Pigs, Poultry, Cattle, Sheep, Goats, Rabbits, Horses and Fish. Wageningen Academic Publishers, INRA, Wageningen \& Paris. ISBN 2-7380-1158-6

Savoie, L., Charbonneau, R. and Parent, G. (1989). In Vitro Amino Acid Digestibility of Food Proteins as Measured by the Digestion Cell Technique. Plant Food Hum Nutr 39, 93-107. DOI: 10.1007/BF01092406

Savoie, L. and Gauthier, S.F. (1986). Dialysis Cell for the in Vitro Measurement of Protein Digestibility. J Food Sci 51, 494-498. DOI: 10.1111/j.1365-2621.1986.tb11164.x

Schwechheimer, S.K., Park, E.Y., Revuelta, J.L., Becker, J. and Wittmann, C. (2016). Biotechnology of Riboflavin. Appl Microbiol Biot 100, 2107-2119. DOI: 10.1007/s00253-015-7256-z

Schwediauer, P., Hagmüller, W. and Zollitsch, W. (2017). Germination of Faba Beans (Vicia Faba L.) for Organic Weaning Piglets. Org Agr. DOI: 10.1007/s13165-017-0195-5

Shafey, T.M., McDonald, M.W. and Dingle, J.G. (1991). Effects of Dietary Calcium and Available Phosphorus Concentration on Digesta $\mathrm{Ph}$ and on the Availability of Calcium, Iron, Magnesium and Zinc from the Intestinal Contents of Meat Chickens. Br Poult Sci 32, 185-194. DOI: 10.1080/00071669108417339

Shewry, P.R., Van Schaik, F., Ravel, C., Charmet, G., Rakszegi, M., Bedo, Z. and Ward, J.L. (2011). Genotype and Environment Effects on the Contents of Vitamins B1, B2, B3, and B6 in Wheat Grain. J Agr Food Chem 59, 10564-10571. DOI: 10.1021/jf202762b

Shires, A., Thompson, J.R., Turner, B.V., Kennedy, P.M. and Goh, Y.K. (1987). Rate of Passage of Corn-Canola Meal and Corn-Soybean Meal Diets through the Gastrointestinal Tract of Broiler and White Leghorn Chickens. Poult Sci 66, 289-298. DOI: 10.3382/ps.0660289

Short, F.J., Wiseman, J. and Boorman, K.N. (1999). Application of a Method to Determine lleal Digestibility in Broilers of Amino Acids in Wheat. Anim Feed Sci Tech 79, 195-209. DOI: 10.1016/S0377-8401(99)00022-X

Sibbald, I.R. (1987). Estimation of Bioavailable Amino-Acids in Feedingstuffs for Poultry and Pigs - a Review with Emphasis on Balance Experiments. Can J Anim Sci 67, 221-301. ISSN: 0800-3984

Siriwan, P., Bryden, W.L., Mollah, Y. and Annison, E.F. (1993). Measurement of Endogenous Amino Acid Losses in Poultry. Br Poult Sci 34, 939-949. DOI: 10.1080/00071669308417654

Snape, J.W., Foulkes, M.J., Simmonds, J., Leverington, M., Fish, L.J., Wang, Y. and Ciavarrella, M. (2007). Dissecting Gene x environmental Effects on Wheat Yields Via Qtl and Physiological Analysis. Euphytica 154, 401-408. DOI: 10.1007/s10681-006-9208-2

Squires, V.R. (2011). The Role of Food, Agriculture, Forestry and Fisheries in Human Nutrition - Volume Iv. S. 125. ISBN: 9781848261952

Stahmann, K.P., Revuelta, J.L. and Seulberger, H. (2000). Three Biotechnical Processes Using Ashbya Gossypii, Candida Famata, or Bacillus Subtilis Compete with Chemical Riboflavin Production. Appl Microbiol Biotechnol 53, 509-516. DOI: 10.1007/s002530051649

Sundrum, A., Butfering, L., Henning, M. and Hoppenbrock, K.H. (2000). Effects of on-Farm Diets for Organic Pig Production on Performance and Carcass Quality. Anim Sci 78, 1199-1205.

Toghyani, M., Rodgers, N., lji, P.A. and Swick, R.A. (2015). Standardized Ileal Amino Acid Digestibility of Expeller-Extracted Canola Meal Subjected to Different Processing Conditions for Starter and Grower Broiler Chickens. Poult Sci 94, 992-1002. DOI: 10.3382/ps/pev047

Urbatzka, P., Graß, R., Haase, T., Schüler, C., Trautz, D. and Heß, J. (2011). Grain Yield and Quality Characteristics of Different Genotypes of Winter Pea in Comparison to Spring Pea for Organic Farming in Pure and Mixed Stands. Org Agr, 187-202. DOI: 10.1007/s13165-011-0015-2

Valentim, J.K., de Paula, K.L.C., Geraldo, A., Miranda, D.A., Antunes, H.C.F., Lemke, S.S.R., Gonzaga, P.R.d.N. and Chaves, C.A.R. (2017). Usage of Probiotic in Country-Type Broiler's Chicken Diet and Its Effects over the Carcass Yield, Morphology and the Gastrointestinal Ph. Rev bras saúde prod anim 18, 530-541. DOI: 10.1590/s1519-99402017000400004

Van Krimpen, M.M., Kwakkel, R.P., Reuvekamp, B.F.J., Van Der Peet-Schwering, C.M.C., Den Hartog, L.A. and Verstegen, M.W.A. (2005). Impact of Feeding Management on Feather Pecking in Laying Hens. World Poult Sci J 61, 663-686. DOI:10.1079/WPS200478

Van Soest, P.J. (1967). Development of a Comprehensive System of Feed Analyses and Its Application to Forages. Anim Sci 26, 119-128. DOI: 10.2527/jas1967.261119x 
Velicka, R., Marcinkeviciene, A., Pupaliene, R., Butkeviciene, L.M., Kosteckas, R., Cekanauskas, S. and Kriauciuniene, Z. (2016). Winter Oilseed Rape and Weed Competition in Organic Farming Using NonChemical Weed Control. Zemdirbyste 103, 11-20. DOI: 10.13080/z-a.2016.103.002

Webb, M.E., Marquet, A., Mendel, R.R., Rebeille, F. and Smith, A.G. (2007). Elucidating Biosynthetic Pathways for Vitamins and Cofactors. Nat Prod Rep 24, 988-1008. DOI: 10.1039/b703105j

Wecke, C. and Liebert, F. (2013a). Improving the Reliability of Optimal in-Feed Amino Acid Ratios Based on Individual Amino Acid Efficiency Data from N Balance Studies in Growing Chicken. Animals 3, 558573. DOI: 10.3390/ani3030558

Wecke, C. and Liebert, F. (2013b). Umweltverträgliche Protein- und Aminosäuren-Versorgung von Geflügel und Schwein nach dem Konzept des Idealproteins [Environmentally Compatible Protein and Amino Acid Supply of Poultry and Pigs According to the Concept of the Ideal Protein], In: Ebertseder, P.D.T., Danier, J., Killermann, D.B., Nätscher, D.L., Severin, D.K., Südekum, P.D.K.-H., Trenkle, D.A. and Wiesler, P.D.F. (Eds.), Vdlufa-Schriftenreihe Band 69/2014, Verband Deutscher Landwirtschaftlicher Untersuchungs- und Forschungsanstalten, ISBN 978-3-941273-15-3, Berlin, p. 695.

Wecke, C., Pastor, A. and Liebert, F. (2016). Validation of the Lysine Requirement as Reference Amino Acid for Ideal in-Feed Amino Acid Ratios in Modern Fast Growing Meat-Type Chickens. Open J Anim Sci 6, 10. DOI: 10.4236/ojas.2016.63024

Weißmann, F. (2017). Personal Communication of Dr. Friedrich Weißmann in the Context of the Discussion on "Organic Farming - Looking Forwards" Strategy Towards Greater Sustainability in Germany, ThünenInstitute of Organic Farming, Germany.

Weißmann, F. and Bussemas, R. (2014). Praktische Möglichkeiten zur Verbesserung der Eiweißversorgung der Monogastrier im Ökologischen Landbau [Protein Supply of Monogastric Animals in Organic Farming], Praxisbefragung zur Aminosäurelücke und praktische Möglichkeiten zur Verbesserung der Eiweißversorgung der Monogastrier in der Fütterung im Ökologischen Landbau, Thünen Working Paper 23.

Weurding, R.E., Veldman, A., Veen, W.A.G., van der Aar, P.J. and Verstegen, M.W.A. (2001). Starch Digestion Rate in the Small Intestine of Broiler Chicken Differs among Feedstuffs. J Nutr 131, 2329-2335. DOI: $10.1093 / \mathrm{jn} / 131.9 .2329$

Wickham, M., Faulks, R. and Mills, C. (2009). In Vitro Digestion Methods for Assessing the Effect of Food Structure on Allergen Breakdown. Mol Nutr Food Res 53, 952-958. DOI:10.1002/mnfr.200800193

Wiseman, J., Al-Mazooqi, W., Welham, T. and Domoney, C. (2003). The Apparent lleal Digestibility, Determined with Young Broilers, of Amino Acids in near-Isogenic Lines of Peas (Pisum Sativum $L$ ) Differing in Trypsin Inhibitor Activity. J Sci Food Agric 83, 644-651. DOI: 10.1002/jsfa.1340

Witten, S. and Paulsen, H.M. (2014). Recherche Zum Praxisstand der Versorgung mit Eiweißfuttermitteln zur Deckung von Aminosäurelücken in der Fütterung der Monogastrier im Ökologischen Landbau (Praxisbefragung zur Aminosäurelücke) [Survey on Practice of the Use and Availability of Protein Sources to Close Amino Acid Gaps in Feeding Monogastric Animals in Organic Farming], Praxisbefragung zur Aminosäurelücke und praktische Möglichkeiten zur Verbesserung der Eiweißversorgung der Monogastrier in der Fütterung im Ökologischen Landbau, Thünen Working Paper 23.

Wu, G., Wu, Z., Dai, Z., Yang, Y., Wang, W., Liu, C., Wang, B., Wang, J. and Yin, Y. (2013). Dietary Requirements of "Nutritionally Non-Essential Amino Acids" by Animals and Humans. Amino Acids 44. DOI: $10.1007 / \mathrm{s} 00726-012-1444-2$

Wüstholz, J., Carrasco, S., Berger, U., Sundrum, A. and Bellof, G. (2017a). Fattening and Slaughtering Performance of Growing Pigs Consuming High Levels of Alfalfa Silage (Medicago Sativa) in Organic Pig Production. Livest Sci 200, 46-52. DOI: 10.1016/j.livsci.2017.04.004

Wüstholz, J., Carrasco, S., Berger, U., Sundrum, A. and Bellof, G. (2017b). Silage of Young Harvested Alfalfa (Medicago Sativa) as Home-Grown Protein Feed in the Organic Feeding of Laying Hens. Org Agr 7, 153-163. DOI: 10.1007/s13165-016-0151-9

Zhan, X.A., Wang, M., Ren, H., Zhao, R.Q., Li, J.X. and Tan, Z.L. (2007). Effect of Early Feed Restriction on Metabolic Programming and Compensatory Growth in Broiler Chickens. Poult Sci 86, 654-660. DOI: $10.1093 / p s / 86.4 .654$

Zollitsch, W. (2007). Challenges in the Nutrition of Organic Pigs. J Sci Food Agr 87, 2747-2750. DOI: $10.1002 / J s f a .3003$ 



\section{Chapter I}

\section{Effect of variety and environment on the contents of crude nutrients} and amino acids in organically produced cereal and legume grains

Einfluss von Sorte und Umwelt auf die Rohnährstoff- und Aminosäurengehalte in ökologisch erzeugten Getreide- und Leguminosenkörnern

Stephanie Witten, Herwart Böhm, Karen Aulrich

Johann Heinrich von Thünen-Institute of Organic Farming, Trenthorst 32, 23847

Westerau, Germany

Witten, S., Böhm, H., Aulrich, K.: Effect of variety and environment on the contents of crude nutrients and amino acids in organically produced cereal and legume grains.

Preprint: Submitted to the Journal of Organic Agriculture 


\section{Abstract}

Cereals and home-grown grain legumes are main feedstuffs for monogastric animals. Thus, knowledge on variations of their crude nutrient and amino acid composition is of great interest in animal nutrition. Genetic and environmental factors are known to be able to affect the nutrient composition of crops. Thus, the aim of the study was to analyse a selection of grains of organic cereal and grain legume cultivars for their crude nutrient and amino acid contents and to determine the effect of variety and environmental conditions on the variations. Furthermore, it was tested, if equations can be used to predict amino acid contents from the crude protein content of cereals and grain legumes.

The content of the crude nutrients and 18 amino acids of 835 samples of ten different cereal and grain legume cultivars was analysed. Selected nutrients were subjected to correlation analyses. Furthermore, generalised linear models with multiple comparisons were conducted to assess the effect of cultivar as well as of variety, harvest site, and harvest year on the analysed ingredients.

Known differences in the nutrient composition between cultivars were confirmed. The contents of all crude nutrients and amino acids varied depending on the cultivar and the considered nutrient. The lowest variation coefficients $(1.3-2.6 \%$ in cereals and $3.1,3.5$, and $6.8 \%$ in field peas, field beans, and blue lupins, respectively) were observed for the contents of nitrogen-free extracts. The crude protein contents varied widely, specifically in winter rye (Coefficient of variation: $\mathrm{CV}=17.4 \%$ ). However, compared to table values, the cereals and grain legumes of the present study tended to contain low amounts of crude protein and high amounts of starch. Due to the wide variations, there is no distinct consistency between table values and the results of this study.

High negative correlations between starch and crude protein contents were observed in eight cultivars. Furthermore, the amino acid profile of cereals and grain legumes varied depending on the crude protein contents. Higher crude protein contents were often related to lower contents of several essential amino acids in favour of glutamine/glutamic acid, proline, and phenylalanine in cereals as well as of arginine in grain legumes. Furthermore, variety, harvest site, and harvest year affected the contents of the analysed ingredients depending on the cultivar. However, the environmental factors had a greater influence than the variety. The observed variations must be regarded in diet formulation. Equations can be used to predict the amino acid contents of cereals and grain legumes from their crude protein content. However, additional analysis results are needed to improve the predictability with equations.

\section{Keywords}

organic farming, harvest site, cultivation year 


\section{Zusammenfassung}

Getreide und heimische Körnerleguminosen sind wichtige Futtermittel für monogastrische Nutztiere. Daher ist das Wissen über Schwankungen ihrer Nährstoffzusammensetzung von großem Interesse für die Tierernährung. Neben den Rohnährstoffen haben Aminosäuren als wichtige Bausteine für körpereigene Proteine in den letzten Jahrzehnten an Bedeutung in der Rationsgestaltung gewonnen. Genetische und umweltbedingte Faktoren können die Nährstoffzusammensetzung von Ernteprodukten beeinflussen. Daher war das Ziel dieser Studie, eine Auswahl von Getreide- und Körnerleguminosen aus ökologischer Erzeugung auf ihre Gehalte an Rohnährstoffen und Aminosäuren zu analysieren, die Schwankungen abzubilden und den Einfluss von Sorte und Umweltbedingungen zu beschreiben. Zudem wurde geprüft, ob die Aminosäurengehalte zufriedenstellend aus dem Rohproteingehalt geschätzt werden können.

Zu diesem Zweck wurden die Gehalte an Rohnährstoffen und 18 Aminosäuren in 835 Proben von Körnern zehn verschiedener Getreide- und Körnerleguminosenkulturen analysiert und kulturartenweise Korrelationsanalysen unterzogen. Multiple Mittelwertvergleiche wurden zudem durchgeführt, um den Effekt der Kultur sowie von Sorte, Anbauort und Anbaujahr auf die Inhaltsstoffgehalte zu bestimmen.

Bekannte Unterschiede der Nährstoffzusammensetzung zwischen den Kulturen wurden bestätigt. Abweichungen der Aminosäurengehalte von Tabellenwerten waren nicht konsistent für alle Kulturen. Die Gehalte aller untersuchten Inhaltsstoffe schwankten abhängig von der betrachteten Kultur und dem Inhaltsstoff stark. Die geringsten Variationskoeffizienten (1.3 - 2.6\% in Getreide, 3.1, 3.5, und 6.8\% in Erbsen, Ackerbohnen und blauen Lupinen) wurden für $\mathrm{N}$-freie Extraktstoffe beobachtet. Die Rohproteingehalte variierten jedoch stark zwischen den Proben, vor allem bei Roggen (CV = 17.4\%). Im Vergleich zu Tabellenwerten wurden geringere Rohprotein- und höhere Stärkegehalte beobachtet. Das Verhältnis von Rohprotein- und Stärkegehalten war auch in einer starken negativen Korrelation dieser Nährstoffe zu sehen. Zudem veränderte sich das Aminosäurenprofil zugunsten von Glutamin/-säure, Prolin und Phenylalanin in Getreide bzw. von Arginin in Körnerleguminosen bei steigendem Rohproteingehalt. Dabei wurden sinkende Gehalte einiger limitierenden Aminosäuren beobachtet. Die beobachteten Schwankungen, die auch von Sorte, Anbauort und Anbaujahr beeinflusst werden, müssen in der Rationsgestaltung Beachtung finden. Der Einsatz von Gleichungen zur Schätzung der Aminosäurengehalte aus dem Rohproteingehalt ist dabei möglich.

\section{Schlüsselworte}

Ökolandbau, Anbauort, Anbaujahr 


\section{Introduction}

Comprehensive knowledge on the nutrient composition of feedstuffs is essential in modern animal feeding. For this reason, several institutions summarised data on feed composition in various feed value tables (e. g., Ajinomoto Animal Nutrition Group 2003-2013, DLG 20062010, Agroscope 2011-2016, Evonik 2016). The reported values indicate wide variations of the nutrient contents of plant feedstuffs. It is challenging to formulate diets with an optimal nutrient composition using self-cultivated crops considering the variability of the contents of valuable ingredients. A dependence of this variability on genetic and environmental factors, like variety, weather conditions, soil characteristics, and cultivation management (Burstin et al. 2011, Shewry et al. 2011, Gronle 2014, Rodehutscord et al. 2016), has been reported. Besides crude nutrient (CN) contents, further components are valuable in describing a feedstuff. To further characterise the crude protein (CP) of feedstuffs, amino acid (AA) contents are of special importance in animal nutrition. It is especially challenging to achieve the sufficient supply of some essential AA in organic farming (Zollitsch \& Baumung 2004, Weißmann \& Bussemas 2014).

Diets for monogastric animals are often cereal-based. Cereals have high starch contents and are, therefore, an important energy supplier. They can be cultivated on any farm with comparatively low costs. Therefore, they also contribute to the intended circular ecology of organic farms. Cereal grains contain only about $10 \%$ CP. However, common diets for monogastric animals often have high inclusion rates of cereal grains. Thus, the dietary AA supply and profile are affected by the CP originating from cereals. Cereal protein has relatively low amounts of lysine (Lys) and threonine (Thr) but high amounts of the sulphurcontaining amino acids (SAA) methionine (Met) and cystine (Cys) (Boisen et al. 2000).

In addition to cereals, different feedstuffs can be used, for example, to increase the supply of $C P$ and $A A$ and to adjust the relation between the essential AA in the diet. Due to legal regulations in organic farming, several protein feedstuffs are not allowed to be fed (EC 2007, 2008, EU 2014). Grain legumes, like soybeans, beans, peas, and lupins, which contain large amounts of CP and Lys, are important protein feedstuffs not only in organic but also in conventional farming (Jezierny et al. 2010). Many of them can even be cultivated on a local scale. Furthermore, they are beneficial in crop rotation through $\mathrm{N}$-fixation and positive effects on soil fertility and yield potential of succeeding crops (Stockdale et al. 2006, Watson et al. 2006, Peoples et al. 2009). However, the cultivation of GMO-free soybeans is rare due to possible benefits of genetically modified soybeans (Brookes \& Barfoot 2018a, b). Furthermore, there is a demand for soybeans, and specifically GMO-free soybeans, in human nutrition (Teuscher et al. 2005, Würschum et al. 2018). Consequently, the relevance of the other grain legumes is further increased in animal nutrition. 
The objective of the study was, therefore, to determine the variation of the $\mathrm{CN}$, starch, and AA contents in a selection of organic cereals and grain legumes and to evaluate effects of the variety and environmental conditions on the contents of $\mathrm{CN}$, starch, and AA. Another aim of the study was to evaluate the value of regression equations to predict $A A$ contents from the CP content of the studied cereals and grain legumes.

\section{Materials and Methods}

\section{Sample Set}

A selection of harvest samples of cereals and grain legumes from organically managed field trials was collected in the years 2011, 2012, and 2013. The sample set (Table I 1) was the same as in an earlier study by Witten \& Aulrich (2018) and was equally adjusted.

Table I1: Total number of samples ( $n$ total), number of samples considered for further statistical analyses ( $n$ subset), and number of factor manifestations for each cultivar

\begin{tabular}{|c|c|c|c|c|c|c|}
\hline & $\mathrm{n}$ total & n subset & varieties & years & sites & areas $^{1}$ \\
\hline \multicolumn{7}{|l|}{ Cereals } \\
\hline Winter wheat (Triticum aestivum L.) & 106 & 70 & 3 & 3 & & 5 \\
\hline Spring wheat (Triticum aestivum L.) & 45 & 25 & 4 & 3 & & 3 \\
\hline Winter rye (Secale cereale L.) & $106^{2}$ & 81 & 5 & 3 & 7 & \\
\hline Winter triticale (Triticosecale) & $107^{3}$ & 92 & 7 & 3 & & 5 \\
\hline Winter barley (Hordeum vulgare L.) & 30 & 15 & 3 & 2 & 5 & \\
\hline Spring barley (Hordeum vulgare L.) & 66 & 47 & 4 & 3 & & 4 \\
\hline Oats (Avena sativa L.) & $105^{4}$ & 80 & 7 & 3 & 6 & \\
\hline \multicolumn{7}{|l|}{ Grain legumes } \\
\hline Spring field pea (Pisum sativum L.) & 87 & 41 & 6 & 3 & 4 & \\
\hline Spring field bean (Vicia faba L.) & 73 & 59 & 6 & 2 & & 3 \\
\hline Blue lupin (Lupinus angustifolius L.) & 110 & 31 & 5 & 3 & 3 & \\
\hline Total & 835 & 541 & & & & \\
\hline
\end{tabular}

${ }^{1}$ cultivation areas with homogenous climatic conditions according to $\mathrm{JKI}(2018)$;

${ }^{2}$ tryptophan $n=19 ;{ }^{3}$ tryptophan $n=25 ;{ }^{4}$ tryptophan $n=18$

\section{Laboratory analyses}

Immediately after harvesting, the samples were sent to the laboratory of the Thünen Institute of Organic Farming. Subsequently, samples were dried at $40^{\circ} \mathrm{C}$ and either ground to pass through a $1.0 \mathrm{~mm}$ sieve for $\mathrm{CN}$ analyses or through a $0.5 \mathrm{~mm}$ sieve for $A A$ analysis. The analysis of $\mathrm{CN}$ and starch contents was performed according to the official VDLUFA methods (VDLUFA 2012).

Contents of amino acids in cereals and grain legumes were analysed according to Directive (EC) No 152/2009 (EC 2009). The analysis was modified regarding derivatisation, separation, and detection of the hydrolysate AA according to Cohen \& Michaud (1993). Therefore, after oxidation and/or acidic hydrolysis or base hydrolysis for tryptophan, the $\mathrm{pH}$ of the sample was adjusted with sodium hydroxide to $10.5-11.5$.

An Agilent 1260 Infinity HPLC system equipped with an FLD (Waldbronn, Germany) was used for analytical HPLC separations. Reversed-phase chromatography was performed using a Gemini® $3 \mu \mathrm{m}$ NX-C18 column (150 x 4.6 mm, Phenomenex, Aschaffenburg, 
Germany). A volume of $2 \mu \mathrm{l}$ of the prepared sample was injected. The system was run with a gradient as shown in Table I2. The FLD operated at an excitation wavelength of $250 \mathrm{~nm}$ and an emission wavelength of $400 \mathrm{~nm}$. Standard solutions were obtained from Merck.

Table I 2: $\quad$ Chromatographic gradient conditions for the analysis of amino acids

\begin{tabular}{|c|c|c|c|c|c|}
\hline \multicolumn{3}{|c|}{ HPLC after hydrolyses } & \multicolumn{3}{|c|}{ HPLC after oxidation and hydrolyses } \\
\hline Time (min) & Eluent $A^{1 a}(\%)$ & $\begin{array}{c}\text { Eluent } B^{2} \\
(\%)\end{array}$ & Time (min) & Eluent $\mathrm{A}^{1 \mathrm{~b}}(\%)$ & $\begin{array}{c}\text { Eluent } B^{2} \\
(\%)\end{array}$ \\
\hline & 100 & 0 & & 90 & 10 \\
\hline 0.1 & 90 & 10 & 0.1 & 90 & 10 \\
\hline 14 & 86 & 14 & 14 & 86 & 14 \\
\hline 18 & 83.4 & 16.6 & 18 & 83.4 & 16.6 \\
\hline 33 & 63 & 37 & 25 & 73.9 & 26.1 \\
\hline 34 & 0 & 100 & 26 & 0 & 100 \\
\hline 35.5 & 38 & 62 & 27 & 0 & 100 \\
\hline 37 & 90 & 10 & 31 & 90 & 10 \\
\hline 39 & 100 & 0 & & & \\
\hline
\end{tabular}

${ }^{1} 0.14 \mathrm{M} \mathrm{Na}$-acetate, $0.0173 \mathrm{M}$ triethylamine, $0.8 \mathrm{mM}$ EDTA; apH 5.41; b pH 5.15; 60\% acetonitrile

\section{Statistics}

For each cultivar, means, standard deviations, minima and maxima (ranges) as well as the coefficient of variation (CV) of the $\mathrm{CN}$, starch, and $\mathrm{AA}$ were determined using the complete data set ( $\mathrm{n}$ total in Table 1 ). The AA content in $\mathrm{g} / 16 \mathrm{~g} \mathrm{~N}$ and the relation of each AA to lysine (Lys) were calculated.

Further statistical analyses were conducted using R 3.4.0 (R Core Team 2017). Relationships between CP, EE, CF, and starch as well as between CP and AA were tested using Spearman correlation analyses (package PerformanceAnalytics; Peterson \& Carl (2014). Correlation coefficients higher than $r=0.5$ were considered as marker for strong relations. Linear models $(\mathrm{Im})$ were used to determine equations for each cultivar to estimate $\mathrm{AA}$ contents from the CP content.

The $\mathrm{CN}$ and $\mathrm{AA}$ contents in the cultivars were compared using generalised linear models (glm) with cultivar as factor, a following analysis of variance (Anova) and multiple comparisons (see below). Glm were also implemented on the adjusted data sets ( $n$ subset) to assess the influences of the main factors variety, year, and site or area (Table | 1). Interactions could not be tested due to unbalanced data and the absence of field replicates. The package glmulti (Calcagno 2013) was used to evaluate best-fitted models with only main factors by Akaike's Information Criterion with correction for sample size (AICc). Residuals of $\mathrm{glm}$ were checked for normal distribution with Shapiro-Wilk-Tests. If necessary, a model transformation was added for a better fit. However, small data sets (winter barley, spring wheat, spring barley, and blue lupin) were not transformed. Furthermore, influencing data points were viewed to find outliers, which were not excluded. 


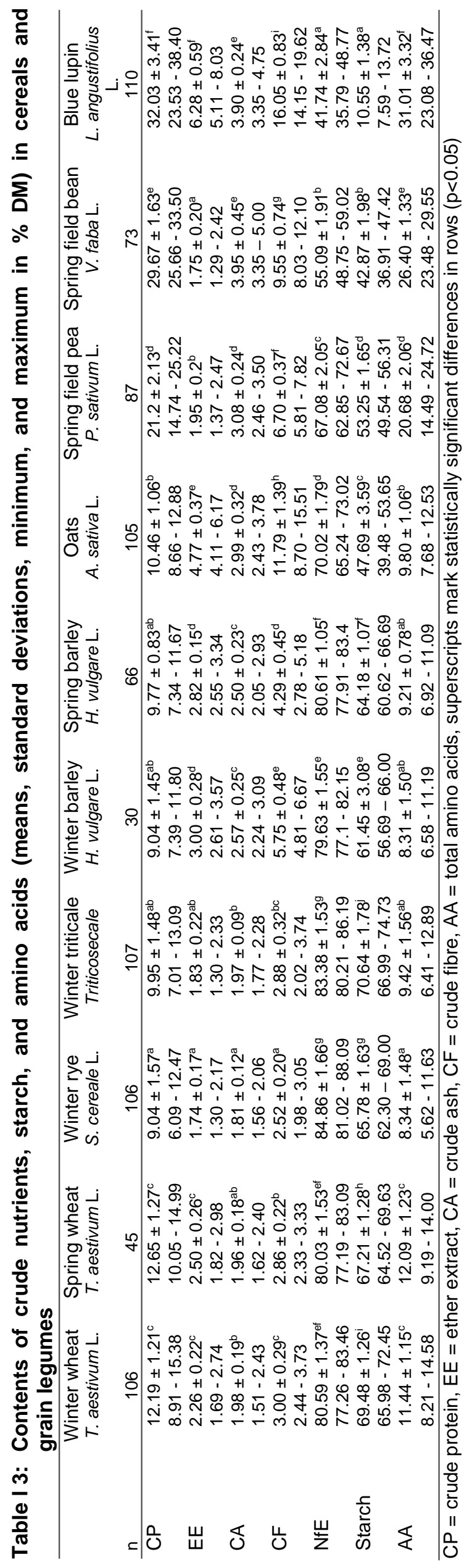


Nevertheless, to validate the robustness of the model, it was tested whether a deletion of influencing data points in a model effectively altered the outcome of the following Anova and the multiple comparisons. Multiple comparisons were calculated using the multcomp package (Hothorn et al. 2008) with Ismeans (Lenth 2016) and Bonferroni-Holm adjustment. Since the assumptions were not met in all cases, the package sandwich (Zeileis 2004) was included regularly for a heteroscedasticity and autocorrelation consistent estimation of covariance with robust standard errors (vcovHAC). Due to the inclusion of this feature, differences between factor manifestations are not found in some cases although the factor is significantly influencing in the glm. Differences between Ismeans were considered significant if $p$-values were lower than 0.05 .

\section{Results}

The $\mathrm{CN}$ contents in cereals and grain legumes varied widely. Cereals contained significantly more starch but less $\mathrm{CP}$, and CA than grain legumes. CF and EE contents were the highest in oats and blue lupins (Table I 3).

Within the cereal cultivars, the highest CP content was observed in wheat $(p<0.05)$ with a maximum of $15.4 \mathrm{~g} / \mathrm{kg} \mathrm{DM}$. The lowest CP content was determined in rye $(6.1 \mathrm{~g} / \mathrm{kg} \mathrm{DM})$, which differed significantly from oats. Oats contained the lowest amounts of NfE and starch, but the highest amounts of EE, CA, and CF $(p<0.05)$. While the contents of CA and CF in winter triticale were equal to those in wheat, the contents of $\mathrm{CP}, \mathrm{EE}$, and NfE were comparable to the ones in rye. The starch content was different in all tested cultivars, while the NfE content in wheat and barley was lower than that in triticale and rye. The spring varieties were observed to have lower CF contents than the winter varieties. The starch and NfE contents were higher in spring barley than in winter barley. However, in wheat, the spring and winter varieties did not have different NfE content, and the starch content was lower in spring wheat than in winter wheat.

Of the grain legume cultivars, blue lupins had the highest contents of CP, EE, CA, and CF. The contents of starch and NfE were very low in blue lupins and high in field peas. The CP content varied by $14 \% \mathrm{DM}$ in blue lupins, by $10.5 \% \mathrm{DM}$ in field peas, and by $7.8 \% \mathrm{DM}$ in field beans. 


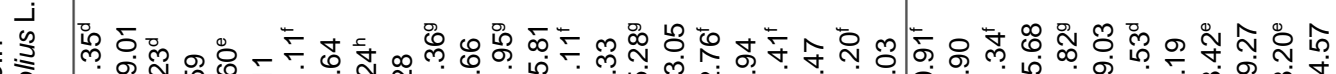
产象의

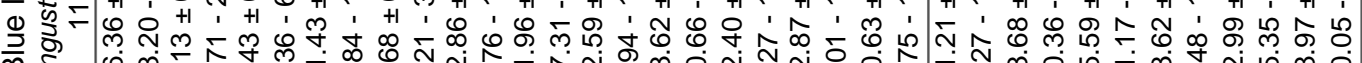

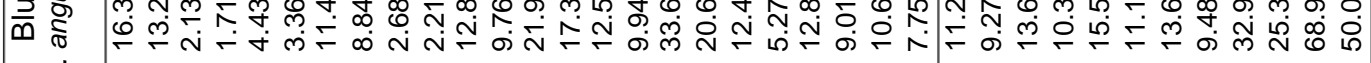

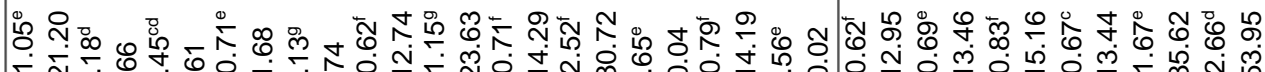

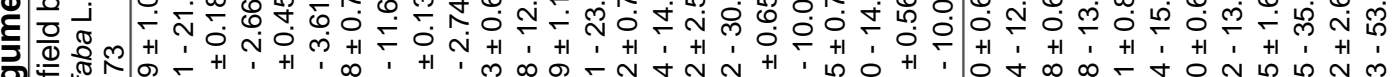

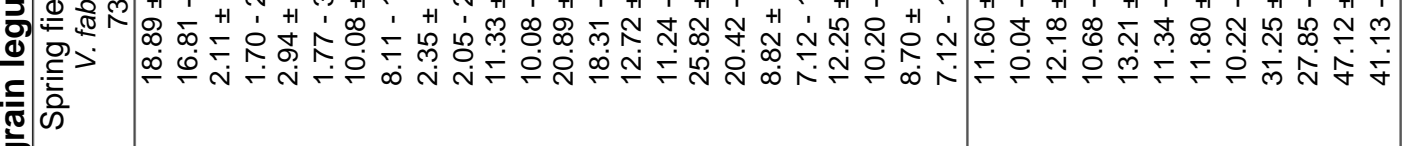

焉

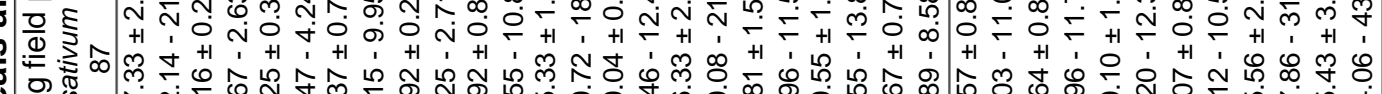

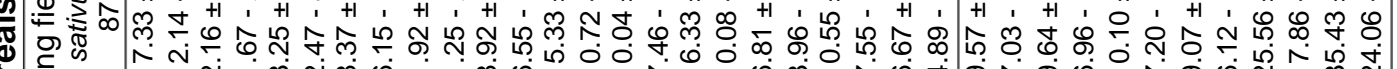

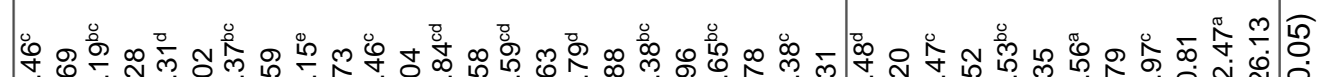

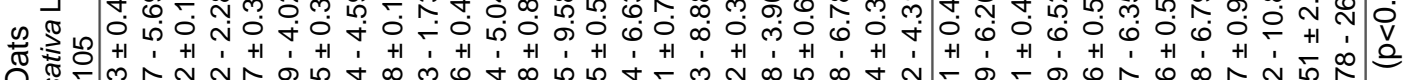

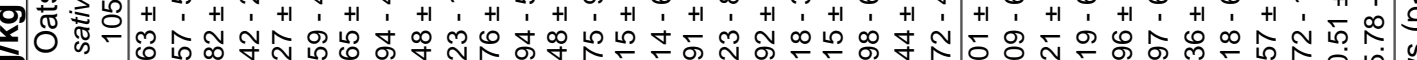

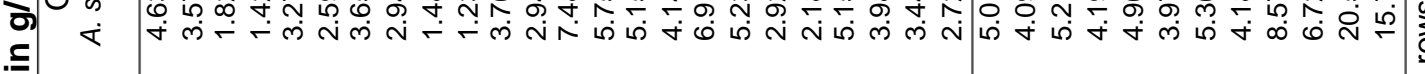

बें

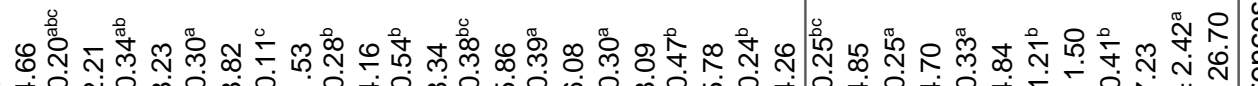

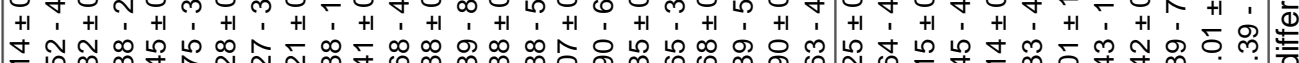
단

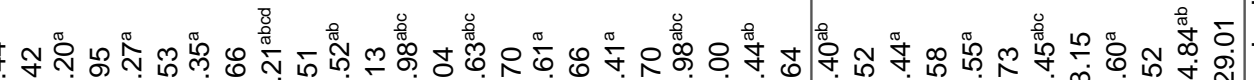

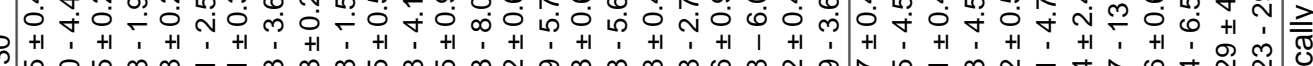

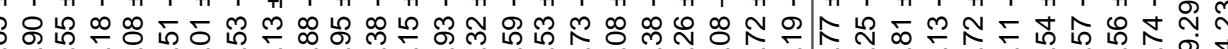

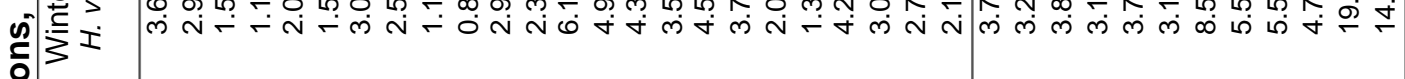

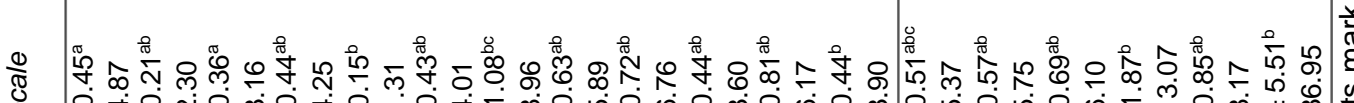

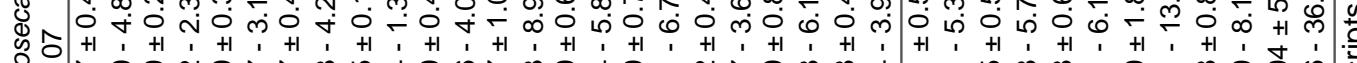

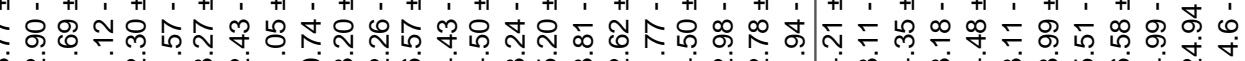

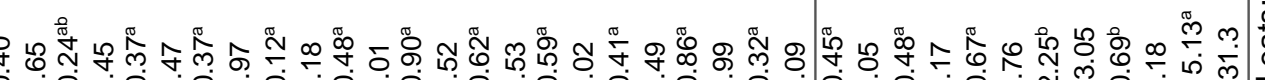

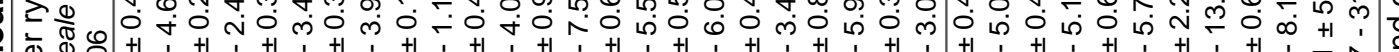
క

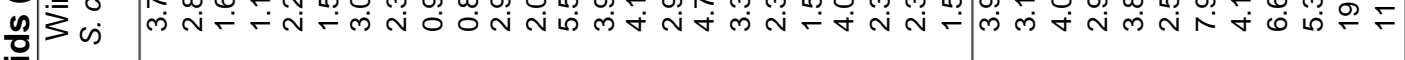

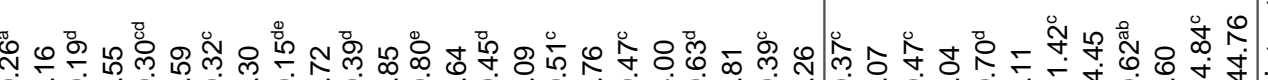

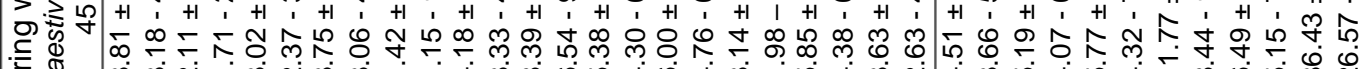

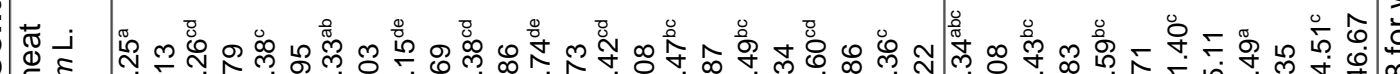
उ

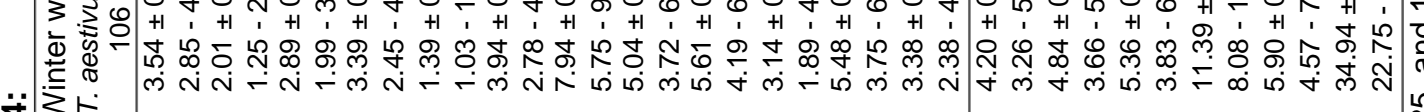

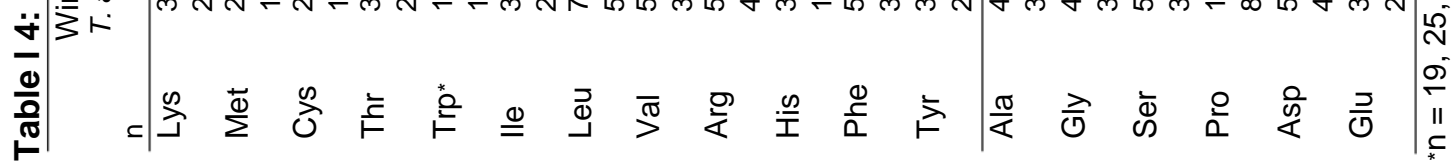


Of the cereal cultivars, winter rye showed the widest variation of the CP content with a coefficient of variation (CV) of $17.4 \%$, followed by winter barley and winter triticale. While the variation coefficient for the CP content in wheat and oats was about $10 \%$, the CP content of spring barley varied less ( $\mathrm{CV}=8.5 \%$ ). The widest variation of the $\mathrm{EE}$ content was observed in winter triticale ( $\mathrm{CV}=12.0 \%$ ), while the lowest variation occurred in spring barley ( $C V=5.3 \%)$. For the CA contents, variation coefficients of $4.6 \%, 6.6 \%$, and about $9-11 \%$ were determined for winter triticale, winter rye, and the other cereal cultivars, respectively. Even CF contents varied widely ( $\mathrm{CV}=8-12 \%)$. With the exception of oats ( $\mathrm{CV}=7.5 \%)$ and winter barley $(\mathrm{CV}=5.0 \%)$, the variations of the starch content were small $(\mathrm{CV}=2.5 \%$ or lower).

In grain legumes, field beans $(\mathrm{CV}=5.5 \%)$ showed a low variation of the $\mathrm{CP}$ content in comparison to field peas and blue lupins (CV =10-11\%). However, the $E E, C A$, and CF contents in field beans varied widely ( $\mathrm{CV}=11.4,11.4$, and $7.7 \%$ ). Although blue lupins contained low amounts of starch, the variation of the starch content was wide (CV $=13.1 \%)$.

The content of the AA in the DM differed significantly between cereal cultivars as well as between grain legume cultivars (Table | 4).

Although wheat was the cereal cultivar that contained the highest amount of CP in the DM, its lysine (Lys) and asparagine/aspartic acid (Asp) contents were low. Spring wheat had significantly higher threonine (Thr) and serine (Ser) contents than winter wheat, and spring barley had high Asp content when compared to winter barley $(p<0.05)$. In contrast to the $\mathrm{CP}$ content, the Lys content in blue lupins was significantly lower than the one of the other grain legumes.

Wide variations of the contents of different $A A$ were observed ( $C V=8-26 \%)$. The CV were lower in wheat, spring barley, and oats than in the other cereal cultivars. Furthermore, wider variations were determined for the contents of proline (Pro), glutamine/glutamic acid (Glu), and phenylalanine (Phe) than for the other AA.

The AA contents in grain legumes mostly varied less widely than those in cereals. Furthermore, the variations of the AA contents were generally low in field beans, and the widest variations were determined for cystine (Cys, CV $=15.3 \%$ ) and arginine (Arg, CV $=9.8 \%$ ). In blue lupins and field peas, wide variations were observed for the content of $\operatorname{Arg}(\mathrm{CV}=15.7$ and $15.1 \%)$ and histidine (His; CV = 22.3 and $22.2 \%)$.

The contents of Lys, Thr, leucine (Leu), isoleucine (lle), His, Arg, tyrosine (Tyr), Ser, and Asp were higher in the $\mathrm{CP}$ of grain legumes compared to the CP of cereals. While the glycine (Gly) content did not differ, the content of Met, Cys, tryptophan (Trp), valine (Val), Phe, alanine (Ala), Pro, and Glu was higher in the CP of cereals compared to the CP of grain legumes (Table I 5). 
돈

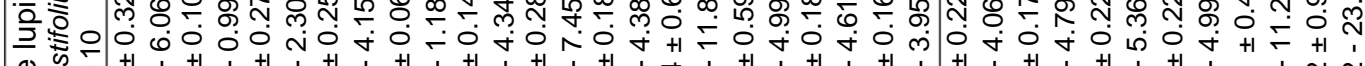

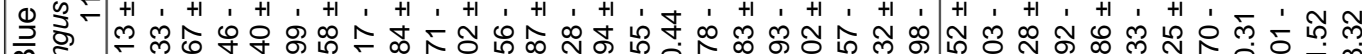

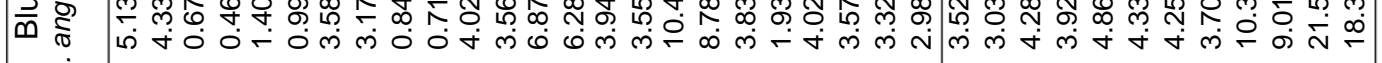

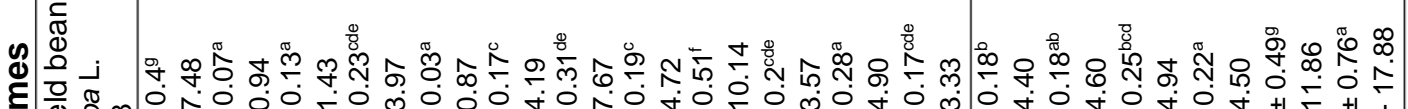
可疋

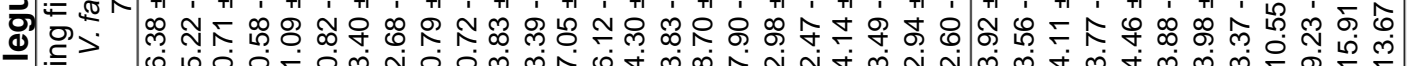

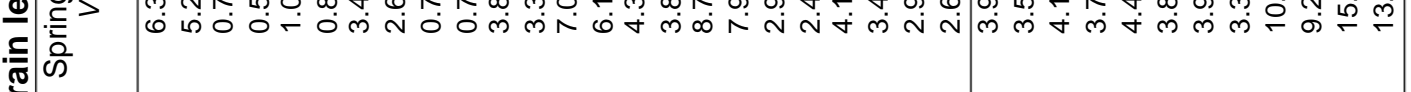

造通 ส 更

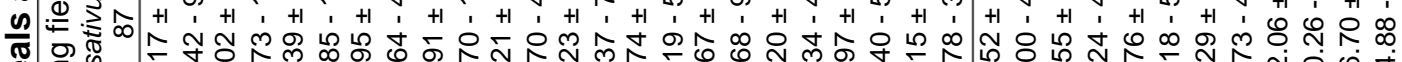

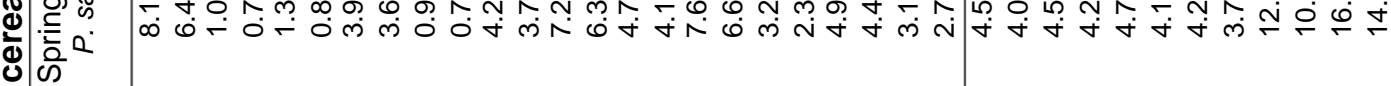

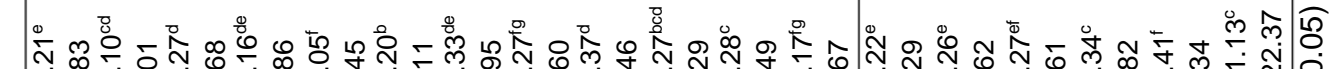

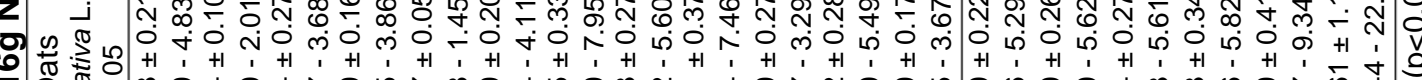

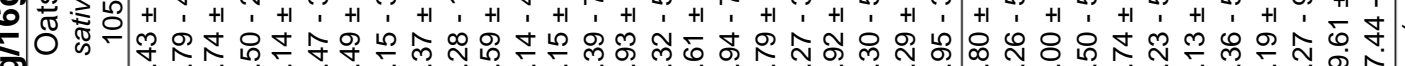

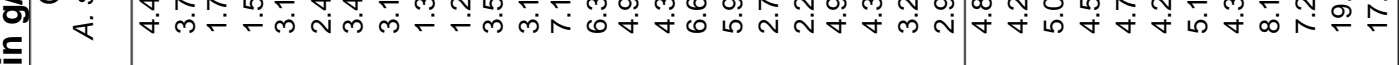

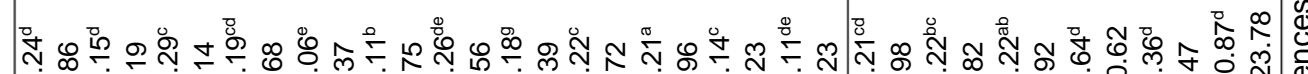

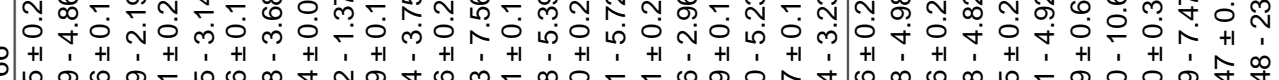

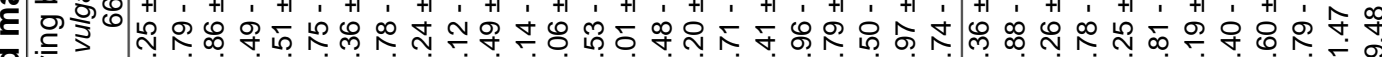

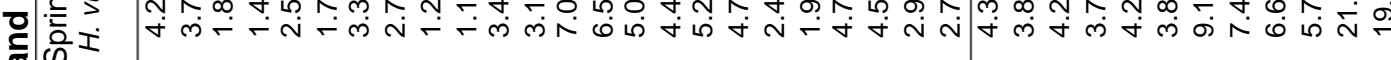

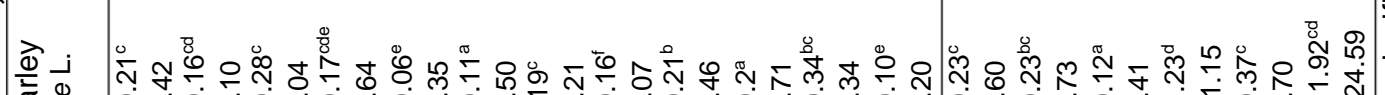

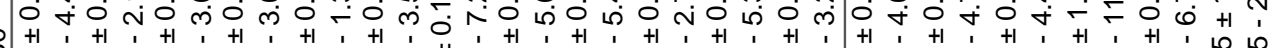

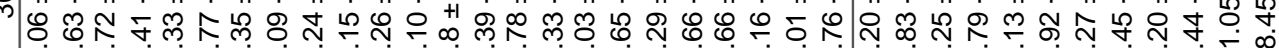
की

品 o to n

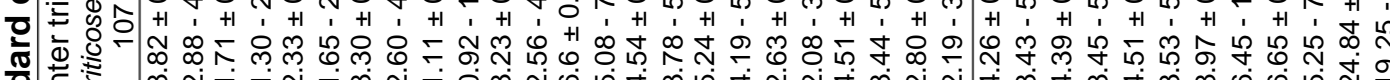

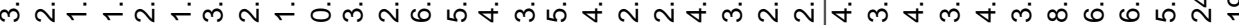

ฮึ

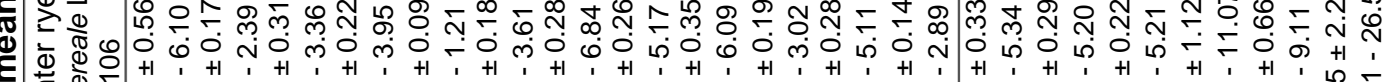

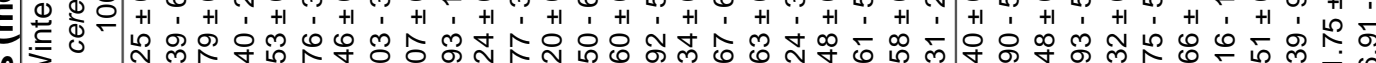

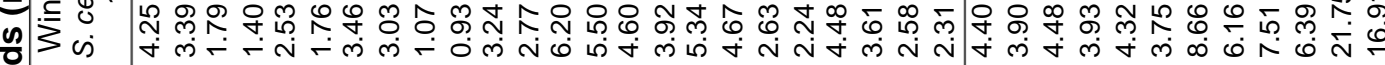

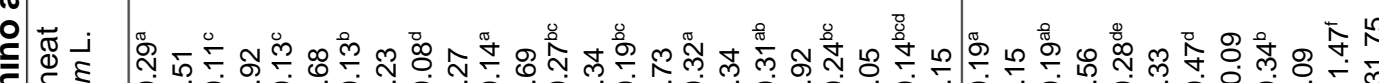

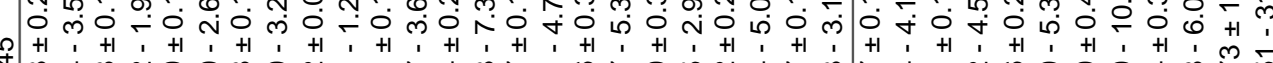

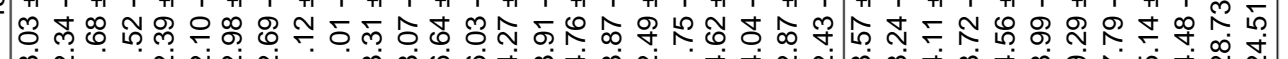

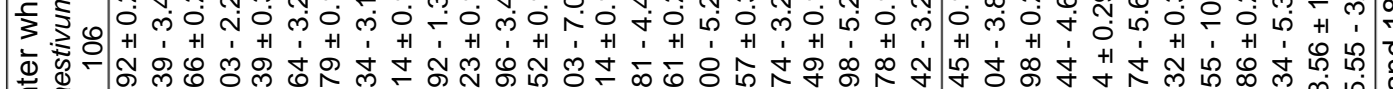
î 向 
The Glu content in the CP of wheat was significantly higher than that in the other cereal cultivars; however, wheat had the lowest Lys and Thr contents in the CP. Spring wheat had significantly higher contents of Thr and Asp in the CP than winter wheat. The CP of spring barley contained significantly higher amounts of Lys, Ile, Leu, Val, Arg, and Asp when compared to winter barley, wheat, rye, and triticale. Pro and Glu accounted for high contents of all other $A A$ in oats. The widest variation of Lys content in the CP was observed in winter rye $(C V=13.2 \%)$. While the variation coefficient ranged between $4-8 \%$ for most $A A$ in cereals and grain legumes, His varied wider in wheat, barley, oats, field peas, and blue lupins, Met and Cys varied wider in grain legumes and winter cereals, Glu and Pro varied wider in winter rye, winter triticale, and winter barley, and Lys varied wider in spring wheat and winter rye.

The CP in field peas contained high amounts of all amino acids (except for Arg and His) in comparison to the other grain legumes. However, due to the high Lys contents in field peas, the ratio of all AA to Lys was lower than in blue lupins and cereals. Only the ratio of Met to Lys content was higher in field peas than in field beans (Table I 6). While the amino acid profile in the CP did not differ between winter and spring wheat, the ratios of Tyr and Gly to Lys were higher in winter barley than in spring barley. Overall, the ratio of the AA to Lys varied widely among and within the cultivars. In cereals, the highest variation coefficient of the ratio to Lys was determined for His and Cys in winter and spring wheat (CV for $\mathrm{His}=$ 14.6 and $15.7 \%$, CV for Cys $=12.0$ and $10.1 \%$ ), for Pro, Glu and Phe in winter rye (CV = 22.5, 19,1, and 25.9\%), for Pro and Glu in winter triticale (CV = 11.0 and 12.4\%), for His in oats (CV $=9.5 \%)$, and in winter and spring barley for Cys (CV = 10.5 and $11.9 \%)$, Pro (CV $=17.0$ and $11.1 \%$ ), and Glu (CV = 13.6 and 8.5\%). In general, field peas had the widest variations of the AA ratio to Lys. The ratio of Arg and His to Lys varied widely in grain legumes. Furthermore, the variation coefficient was specifically high for the relation of Trp to Lys in field peas (CV $=18.2 \%)$, Cys to Lys in field beans ( $C V=11.8 \%)$, and Met and Cys to Lys in blue lupins (CV = 15.4 and $14.7 \%)$.

With the exception of oats and spring wheat, the starch content of all cultivars was highly negatively correlated with the CP content $(r=-0.63--0.91, p<0.05)$. Furthermore, the NfE content in all cultivars was negatively correlated with the CP content $(r=-0.4$ in oats, $r=-$ $0.80--0.90$ in the other cultivars, $p<0.05$ ) and with the exception of spring wheat positively correlated with the starch content. In blue lupins and winter barley, the EE content was negatively correlated with the CP content $(r=-0.62$ and $-0.63, p<0.05)$ and positively with the starch content $(r=0.55$ and $0.75, p<0.05)$. In oats, the CF content was negatively correlated with the content of starch $(r=-0.75, p<0.05)$. Furthermore, the EE content of spring wheat was positively correlated with its CP content $(r=0.63, p<0.05)$. 
$\therefore \stackrel{n}{?}$

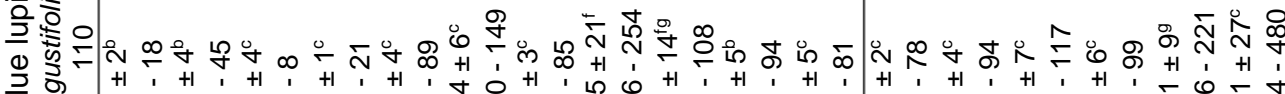

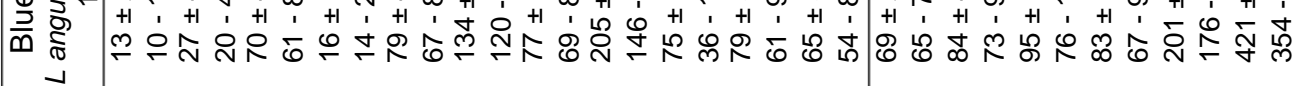
ฮ్

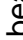

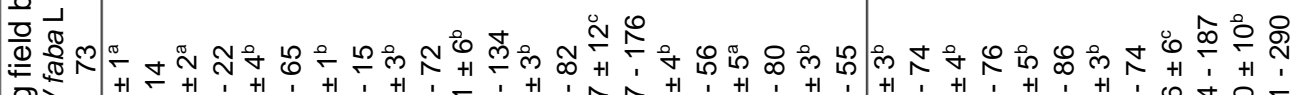
至

๙

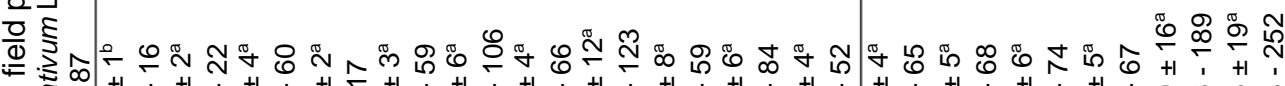

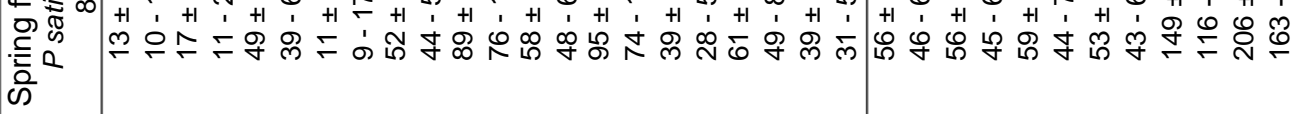

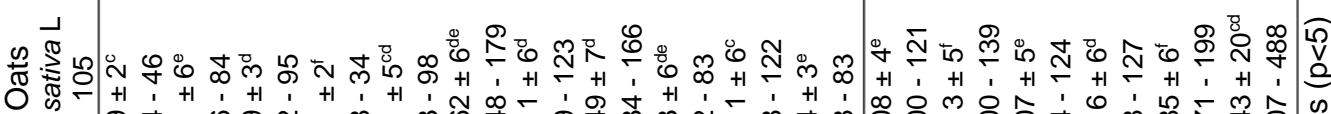

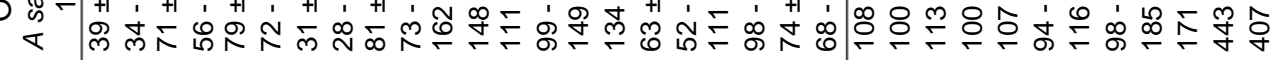
बे

离离

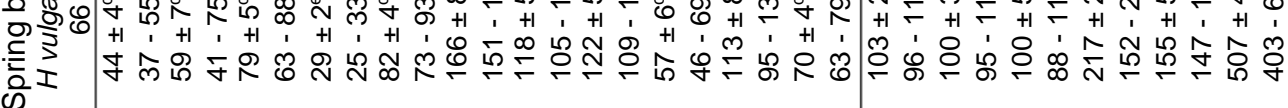


In cereals and grain legumes, the contents of some AA (in g/16 N) were correlated with the CP content (Table I 7). In all cereals, except for oats, the contents of Glu and Pro and in some cases Phe (in $\mathrm{g} / 16 \mathrm{~g} \mathrm{~N}$ ) were positively correlated with the CP content. Furthermore, in winter barley, Trp increased significantly in the CP with increasing CP contents. In the $\mathrm{CP}$ of grain legumes, the contents of Arg and of His in blue lupins increased with increasing $\mathrm{CP}$ contents. In oats, a moderate negative correlation between the CP content and the content of Cys and Gly in the CP was found, while no correlations with the other AA were observed. In the other cereal cultivars, in field beans and in blue lupins, the Lys content of the CP decreased with increasing CP contents. With the exception of spring barley and oats, all cultivars had decreasing Met contents of the CP when CP contents increased. Further negative correlations were found mainly with Val, Arg, Ala, Gly, and Asp in cereals.

Table I 7: Spearman correlation coefficients of the amino acids $(\mathrm{g} / 16 \mathrm{~g} \mathrm{~N})$ and crude protein

\begin{tabular}{|c|c|c|c|c|c|c|c|c|c|c|}
\hline \multicolumn{11}{|c|}{ (\% DM) } \\
\hline & WW & SW & WR & WT & WB & SB & $\mathrm{O}$ & FP & FB & $\mathrm{BL}$ \\
\hline $\mathrm{n}$ & 106 & 45 & 106 & 107 & 30 & 66 & 105 & 87 & 73 & 110 \\
\hline Lys & $-0.73^{*}$ & $-0.77^{*}$ & $-0.80^{*}$ & $-0.60^{*}$ & $-0.76^{*}$ & $-0.77^{\star}$ & $-0.36^{*}$ & -0.18 & $-0.42^{*}$ & $-0.55^{*}$ \\
\hline Met & $-0.48^{*}$ & $-0.41^{*}$ & $-0.61^{*}$ & $-0.58^{\star}$ & $-0.64^{*}$ & -0.10 & $-0.22^{*}$ & $-0.48^{*}$ & $-0.47^{*}$ & $-0.57^{*}$ \\
\hline Cys & $-0.44^{*}$ & -0.25 & $-0.53^{*}$ & $-0.29^{*}$ & $-0.45^{\star}$ & -0.16 & $-0.47^{*}$ & $-0.28^{*}$ & $-0.44^{*}$ & $-0.58^{*}$ \\
\hline Thr & $-0.34^{*}$ & $-0.46^{*}$ & -0.89 & $-0.33^{\star}$ & $-0.84^{*}$ & $-0.30^{*}$ & $-0.25^{*}$ & $-0.60^{*}$ & $-0.38^{*}$ & $-0.46^{*}$ \\
\hline $\operatorname{Trp}^{\dagger}$ & $-0.31^{*}$ & $-0.32^{*}$ & -0.94 & $-0.60^{*}$ & $0.47^{*}$ & -0.17 & -0.10 & -0.21 & $-0.27^{*}$ & $-0.48^{*}$ \\
\hline $\mathrm{Ile}$ & $-0.21^{*}$ & $-0.36^{*}$ & $-0.34^{*}$ & $-0.38^{\star}$ & 0.17 & $-0.27^{*}$ & 0.13 & $-0.24^{*}$ & $-0.38^{*}$ & $-0.25^{*}$ \\
\hline Leu & $-0.33^{*}$ & -0.29 & -0.39 & 0.16 & -0.02 & $-0.44^{*}$ & 0.00 & -0.01 & $-0.37^{*}$ & $-0.58^{*}$ \\
\hline Val & $-0.55^{\star}$ & $-0.56^{*}$ & $-0.57^{*}$ & $-0.25^{\star}$ & $-0.54^{*}$ & $-0.37^{*}$ & 0.00 & $-0.28^{*}$ & $-0.32^{*}$ & $-0.55^{\star}$ \\
\hline Arg & $-0.54^{*}$ & $-0.56^{*}$ & $-0.84^{*}$ & $-0.27^{\star}$ & $-0.74^{*}$ & $-0.53^{*}$ & 0.01 & $0.49^{\star}$ & $0.49^{*}$ & $0.73^{*}$ \\
\hline His & 0.00 & 0.00 & $-0.25^{*}$ & 0.10 & 0.21 & 0.00 & -0.11 & 0.05 & $-0.30^{*}$ & $0.49^{*}$ \\
\hline Phe & 0.13 & 0.00 & $0.53^{*}$ & $0.46^{*}$ & $0.81^{*}$ & $0.50^{*}$ & $0.23^{*}$ & 0.00 & $-0.51^{*}$ & -0.15 \\
\hline Tyr & 0.00 & 0.00 & $-0.72^{*}$ & 0.00 & 0.00 & $-0.29^{*}$ & -0.07 & -0.17 & $-0.41^{*}$ & -0.10 \\
\hline Ala & $-0.60^{*}$ & $-0.54^{*}$ & $-0.90^{*}$ & $-0.54^{\star}$ & $-0.91^{*}$ & $-0.67^{*}$ & $-0.35^{\star}$ & $-0.58^{*}$ & $-0.35^{*}$ & $-0.59^{*}$ \\
\hline Gly & $-0.46^{*}$ & $-0.40^{*}$ & $-0.90^{*}$ & $-0.43^{*}$ & $-0.82^{*}$ & $-0.69^{*}$ & $-0.43^{*}$ & $-0.40^{*}$ & $-0.31^{*}$ & $-0.33^{*}$ \\
\hline Ser & -0.18 & 0.14 & $-0.21^{*}$ & 0.00 & $-0.65^{\star}$ & $-0.41^{*}$ & -0.18 & 0.00 & $-0.40^{*}$ & 0.00 \\
\hline Pro & $0.48^{\star}$ & 0.25 & 0.84 & $0.68^{*}$ & $0.85^{*}$ & $0.51^{*}$ & $-0.24^{\star}$ & $-0.40^{*}$ & $-0.42^{*}$ & 0.00 \\
\hline Asp & $-0.56^{*}$ & -0.25 & $-0.90^{*}$ & $-0.39^{*}$ & $-0.91^{*}$ & $-0.62^{*}$ & 0.00 & -0.17 & $-0.29 *$ & $-0.26^{*}$ \\
\hline Glu & $0.64^{*}$ & $0.58^{*}$ & $0.81^{*}$ & $0.71^{*}$ & $0.83^{*}$ & $0.64^{*}$ & 0.00 & 0.00 & $-0.26^{*}$ & 0.13 \\
\hline
\end{tabular}

$\overline{\mathrm{WW}}=$ winter wheat; $\mathrm{SW}=$ spring wheat; $\mathrm{WR}=$ winter rye; $\mathrm{WT}=$ winter triticale $; \mathrm{WB}=$ winter barley; $\mathrm{SB}=$ spring barley; $\mathrm{O}=$ oats; $\mathrm{FP}=$ field pea; $\mathrm{FB}=$ field bean; $\mathrm{BL}=$ blue lupin; ${ }^{*}=\mathrm{p}<0.05 ; \mathrm{t} n=19,25$, and 18 for winter rye, winter triticale, and oats

Equations were calculated to predict AA contents from CP content in each cultivar. Most of the equations had a satisfying coefficient of determination $\left(R^{2}>0.5\right)$. All equations to predict the AA contents in winter triticale were suitable. However, Cys contents in barley, rye, and oats and the contents of all SAA in grain legumes, could not be estimated with the equations from this study. Lys, the SAA, and His in wheat, except for spring wheat, could also not be predicted satisfyingly $\left(\mathrm{R}^{2}<0.5\right)$. Furthermore, the equations to estimate Lys and Trp contents of field peas were inappropriate. In field beans, only the equations to predict Trp and Arg contents from the CP contents can be used. 
The following equations can be used to predict AA content from CP content (\% DM):

$\begin{array}{ll}\text { Wheat } & \\ \text { Lys }= & 0.014^{\star} \mathrm{CP}+0.190 \\ \text { Met }= & 0.008^{\star} \mathrm{CP}+0.104 \\ \text { Cys }= & 0.013^{\star} \mathrm{CP}+0.134 \\ \text { CysMet }= & 0.021^{\star} \mathrm{CP}+0.238 \\ \text { Thr }= & 0.024^{\star} \mathrm{CP}+0.050 \\ \text { Trp }= & 0.008^{*} \mathrm{CP}+0.038 \\ \text { Arg }= & 0.034^{*} \mathrm{CP}+0.158 \\ \text { Ile }= & 0.030^{\star} \mathrm{CP}+0.030 \\ \text { Leu }= & 0.060^{\star} \mathrm{CP}+0.073 \\ \text { Val }= & 0.034^{*} \mathrm{CP}+0.091 \\ \text { His }= & 0.025^{\star} \mathrm{CP}+0.003 \\ \text { Phe }= & 0.047^{\star} \mathrm{CP}-0.015 \\ \text { Tyr }= & 0.028^{*} \mathrm{CP}+0.001 \\ \text { Gly }= & 0.033^{\star} \mathrm{CP}+0.093 \\ \text { Ser }= & 0.044^{*} \mathrm{CP}+0.001 \\ \text { Pro }= & 0.108^{*} \mathrm{CP}-0.183 \\ \text { Ala }= & 0.026^{\star} \mathrm{CP}+0.110 \\ \text { Asp }= & 0.038^{\star} \mathrm{CP}+0.134 \\ \text { Glu }= & 0.362^{*} \mathrm{CP}-0.925\end{array}$

\section{Winter wheat}

\begin{tabular}{|c|c|}
\hline Lys $=$ & $0.015^{\star} \mathrm{CP}+0.173$ \\
\hline Met $=$ & $0.006^{\star} \mathrm{CP}+0.129$ \\
\hline Cys $=$ & $0.009 * \mathrm{CP}+0.182$ \\
\hline CysMet = & $0.015^{\star} \mathrm{CP}+0.309$ \\
\hline Thr $=$ & $0.022 * \mathrm{CP}+0.065$ \\
\hline $\operatorname{Trp}=$ & $0.008^{*} \mathrm{CP}+0.040$ \\
\hline $\operatorname{Arg}=$ & $0.033^{\star} \mathrm{CP}+0.157$ \\
\hline$\| \mathrm{e}=$ & $0.030 * \mathrm{CP}+0.025$ \\
\hline Leu $=$ & $0.059^{*} \mathrm{CP}+0.079$ \\
\hline Val $=$ & $0.034^{*} \mathrm{CP}+0.094$ \\
\hline $\mathrm{His}=$ & $0.028^{\star} \mathrm{CP}-0.028$ \\
\hline Phe $=$ & $0.046^{\star} \mathrm{CP}-0.013$ \\
\hline Tyr = & $0.027^{\star} \mathrm{CP}+0.011$ \\
\hline Gly = & $0.031{ }^{*} \mathrm{CP}+0.105$ \\
\hline Ser $=$ & $0.041^{*} \mathrm{CP}+0.040$ \\
\hline Pro $=$ & $0.112^{*} \mathrm{CP}-0.226$ \\
\hline $\mathrm{Ala}=$ & $0.025^{\star} \mathrm{CP}+0.120$ \\
\hline Asp $=$ & $0.034^{\star} \mathrm{CP}+0.171$ \\
\hline Glu = & $0.362^{*} \mathrm{CP}-0.925$ \\
\hline
\end{tabular}

\section{Spring wheat}

$\begin{array}{ll}\text { Lys }= & 0.008^{*} \mathrm{CP}+0.278 \\ \text { Met }= & 0.012^{*} \mathrm{CP}+0.063 \\ \text { Cys }= & 0.020^{*} \mathrm{CP}+0.045 \\ \text { CysMet }= & 0.031^{*} \mathrm{CP}+0.115 \\ \text { Thr }= & 0.023^{*} \mathrm{CP}+0.082 \\ \text { Trp }= & 0.009^{*} \mathrm{CP}+0.033 \\ \text { Arg }= & 0.030^{*} \mathrm{CP}+0.223 \\ \text { lle }= & 0.028^{*} \mathrm{CP}+0.067 \\ \text { Leu }= & 0.058^{*} \mathrm{CP}+0.105 \\ \text { Val }= & 0.032^{*} \mathrm{CP}+0.134 \\ \text { His }= & 0.021^{*} \mathrm{CP}+0.044 \\ \text { Phe }= & 0.045^{*} \mathrm{CP}+0.020 \\ \text { Tyr }= & 0.028^{*} \mathrm{CP}+0.009 \\ \text { Gly }= & 0.032^{*} \mathrm{CP}+0.117 \\ \text { Ser }= & 0.048^{*} \mathrm{CP}-0.033 \\ \text { Pro }= & 0.102^{*} \mathrm{CP}-0.115 \\ \text { Ala }= & 0.025^{*} \mathrm{CP}+0.138 \\ \text { Asp }= & 0.039^{*} \mathrm{CP}+0.156 \\ \text { Glu }= & 0.364^{*} \mathrm{CP}-0.953\end{array}$

\section{Barley}

$\begin{array}{lll}\mathrm{R}^{2}=0.37 & \text { Lys }= & 0.029^{\star} \mathrm{CP}+0.118 \\ \mathrm{R}^{2}=0.17 & \text { Met }= & 0.015^{\star} \mathrm{CP}+0.028 \\ \mathrm{R}^{2}=0.19 & \text { Cys }= & 0.019^{\star} \mathrm{CP}+0.052 \\ \mathrm{R}^{2}=0.19 & \text { CysMet }= & 0.035^{\star} \mathrm{CP}+0.074 \\ \mathrm{R}^{2}=0.66 & \text { Thr }= & 0.027^{\star} \mathrm{CP}+0.065 \\ \mathrm{R}^{2}=0.45 & \text { Trp }= & 0.013^{\star} \mathrm{CP}-0.003 \\ \mathrm{R}^{2}=0.64 & \text { Ile }= & 0.036^{\star} \mathrm{CP}-0.016 \\ \mathrm{R}^{2}=0.87 & \text { Leu }= & 0.067^{\star} \mathrm{CP}+0.030 \\ \mathrm{R}^{2}=0.88 & \text { Val }= & 0.046^{\star} \mathrm{CP}+0.031 \\ \mathrm{R}^{2}=0.83 & \text { Arg }= & 0.044^{\star} \mathrm{CP}+0.068 \\ \mathrm{R}^{2}=0.42 & \text { His }= & 0.027^{\star} \mathrm{CP}-0.031 \\ \mathrm{R}^{2}=0.83 & \text { Phe }= & 0.061^{\star} \mathrm{CP}-0.131 \\ \mathrm{R}^{2}=0.80 & \text { Tyr }= & 0.028^{*} \mathrm{CP}+0.016 \\ \mathrm{R}^{2}=0.74 & \text { Gly }= & 0.029^{\star} \mathrm{CP}+0.124 \\ \mathrm{R}^{2}=0.70 & \text { Ser }= & 0.037^{\star} \mathrm{CP}+0.050 \\ \mathrm{R}^{2}=0.89 & \text { Pro }= & 0.144^{*} \mathrm{CP}-0.489 \\ \mathrm{R}^{2}=0.74 & \text { Ala }= & 0.030^{*} \mathrm{CP}+0.121 \\ \mathrm{R}^{2}=0.65 & \text { Asp }= & 0.046^{\star} \mathrm{CP}+0.173 \\ \mathrm{R}^{2}=0.93 & \text { Glu }= & 0.303^{\star} \mathrm{CP}-0.840\end{array}$

Winter barley

$$
\begin{aligned}
& R^{2}=0.49 \\
& R^{2}=0.07 \\
& R^{2}=0.07 \\
& R^{2}=0.07 \\
& R^{2}=0.65 \\
& R^{2}=0.41 \\
& R^{2}=0.69 \\
& R^{2}=0.90 \\
& R^{2}=0.91 \\
& R^{2}=0.87 \\
& R^{2}=0.48 \\
& R^{2}=0.85 \\
& R^{2}=0.8 \\
& R^{2}=0.74 \\
& R^{2}=0.67 \\
& R^{2}=0.93 \\
& R^{2}=0.77 \\
& R^{2}=0.74 \\
& R^{2}=0.93
\end{aligned}
$$

Lys =

Met $=$

Cys $=$

CysMet =

Thr $=$

$\operatorname{Trp}=$

Arg $=$

Ile $=$

Leu $=$

$\mathrm{Val}=$

His =

Phe =

Tyr =

Gly =

Ser $=$

Pro =

Ala $=$

Asp $=$

Glu =

$$
\begin{aligned}
& 0.029^{\star} \mathrm{CP}+0.101 \\
& 0.012^{\star} \mathrm{CP}+0.050 \\
& 0.013^{\star} \mathrm{CP}+0.095 \\
& 0.024^{\star} \mathrm{CP}+0.144 \\
& 0.024^{\star} \mathrm{CP}+0.087 \\
& 0.015^{\star} \mathrm{CP}-0.018 \\
& 0.042^{\star} \mathrm{CP}+0.078 \\
& 0.035^{\star} \mathrm{CP}-0.020 \\
& 0.066^{\star} \mathrm{CP}+0.013 \\
& 0.043^{\star} \mathrm{CP}+0.043 \\
& 0.026^{\star} \mathrm{CP}-0.025 \\
& 0.067^{\star} \mathrm{CP}-0.178 \\
& 0.030^{\star} \mathrm{CP}+0.003 \\
& 0.030^{\star} \mathrm{CP}+0.113 \\
& 0.037^{\star} \mathrm{CP}+0.041 \\
& 0.167^{\star} \mathrm{CP}-0.653 \\
& 0.028^{\star} \mathrm{CP}+0.128 \\
& 0.040^{\star} \mathrm{CP}+0.195 \\
& 0.332^{\star} \mathrm{CP}-1.069
\end{aligned}
$$

\section{Spring barley}

$R^{2}=0.14$
$R^{2}=0.60$
$R^{2}=0.71$
$R^{2}=0.69$
$R^{2}=0.83$
$R^{2}=0.54$
$R^{2}=0.53$
$R^{2}=0.81$
$R^{2}=0.84$
$R^{2}=0.80$
$R^{2}=0.31$
$R^{2}=0.79$
$R^{2}=0.79$
$R^{2}=0.76$
$R^{2}=0.74$
$R^{2}=0.83$
$R^{2}=0.74$
$R^{2}=0.62$
$R^{2}=0.90$
$0.021^{*} \mathrm{CP}+0.212$

$0.015^{\star} \mathrm{CP}+0.033$

$0.020^{*} \mathrm{CP}+0.047$

$0.037^{\star} \mathrm{CP}+0.069$

$0.028^{*} \mathrm{CP}+0.052$

$0.011^{*} \mathrm{CP}+0.014$

$0.041{ }^{*} \mathrm{CP}+0.111$

$0.058^{\star} \mathrm{CP}+0.120$

$0.043^{\star} \mathrm{CP}+0.074$

$0.026^{*} \mathrm{CP}-0.021$

$0.055^{*} \mathrm{CP}-0.072$

$0.027^{\star} \mathrm{CP}+0.031$

$0.025^{\star} \mathrm{CP}+0.172$

$0.032^{*} \mathrm{CP}+0.101$

$0.133^{\star} \mathrm{CP}-0.396$

$0.025^{\star} \mathrm{CP}+0.176$

$0.279 * \mathrm{CP}-0.626$
$0.031{ }^{*} \mathrm{CP}+0.039$

$0.037^{\star} \mathrm{CP}+0.276$
$R^{2}=0.74$

$R^{2}=0.51$

$R^{2}=0.35$

$R^{2}=0.45$

$R^{2}=0.76$

$R^{2}=0.82$

$R^{2}=0.88$

$\mathrm{R}^{2}=0.89$

$R^{2}=0.88$

$R^{2}=0.84$

$R^{2}=0.68$

$R^{2}=0.96$

$R^{2}=0.91$

$R^{2}=0.82$

$R^{2}=0.83$

$R^{2}=0.88$

$R^{2}=0.79$

$\mathrm{R}^{2}=0.68$

$\mathrm{R}^{2}=0.96$

$R^{2}=0.92$

$\mathrm{R}^{2}=0.67$

$R^{2}=0.44$

$R^{2}=0.67$

$R^{2}=0.95$

$\mathrm{R}^{2}=0.91$

$R^{2}=0.94$

$R^{2}=0.96$

$R^{2}=0.97$

$\mathrm{R}^{2}=0.95$

$R^{2}=0.82$

$R^{2}=0.98$

$\mathrm{R}^{2}=0.95$

$R^{2}=0.93$

$R^{2}=0.97$

$R^{2}=0.97$

$R^{2}=0.96$

$R^{2}=0.94$

$R^{2}=0.99$

$R^{2}=0.60$

$R^{2}=0.38$

$\mathrm{R}^{2}=0.25$

$\mathrm{R}^{2}=0.33$

$R^{2}=0.61$

$R^{2}=0.67$

$\mathrm{R}^{2}=0.74$

$R^{2}=0.85$

$R^{2}=0.81$

$R^{2}=0.83$

$R^{2}=0.51$

$R^{2}=0.93$

$R^{2}=0.83$

$R^{2}=0.66$

$\mathrm{R}^{2}=0.66$

$R^{2}=0.83$

$R^{2}=0.72$

$R^{2}=0.58$

$\mathrm{R}^{2}=0.93$ 
Winter rye

$\begin{array}{ll}\text { Lys }= & 0.018^{\star} \mathrm{CP}+0.213 \\ \text { Met }= & 0.013^{\star} \mathrm{CP}+0.044 \\ \text { Cys }= & 0.017^{\star} \mathrm{CP}+0.073 \\ \text { CysMet } & 0.030^{\star} \mathrm{CP}+0.114 \\ \text { Thr }= & 0.023^{\star} \mathrm{CP}+0.099 \\ \text { Trp }= & 0.007^{\star} \mathrm{CP}+0.033 \\ \text { Ile }= & 0.029^{\star} \mathrm{CP}+0.027 \\ \text { Leu }= & 0.056^{\star} \mathrm{CP}+0.052 \\ \text { Val }= & 0.038^{\star} \mathrm{CP}+0.069 \\ \text { Arg }= & 0.036^{\star} \mathrm{CP}+0.152 \\ \text { His }= & 0.024^{\star} \mathrm{CP}+0.018 \\ \text { Phe }= & 0.054^{\star} \mathrm{CP}-0.079 \\ \text { Tyr }= & 0.020^{\star} \mathrm{CP}+0.049 \\ \text { Gly }= & 0.030^{\star} \mathrm{CP}+0.129 \\ \text { Ser }= & 0.041^{\star} \mathrm{CP}+0.015 \\ \text { Pro }= & 0.140^{\star} \mathrm{CP}-0.470 \\ \text { Ala }= & 0.028^{\star} \mathrm{CP}+0.144 \\ \text { Asp }= & 0.041^{\star} \mathrm{CP}+0.294 \\ \text { Glu }= & 0.321^{*} \mathrm{CP}-0.905\end{array}$

\section{Winter triticale}

$\begin{array}{ll}\text { Lys }= & 0.026^{\star} \mathrm{CP}+0.122 \\ \text { Met }= & 0.012^{\star} \mathrm{CP}+0.054 \\ \text { Cys }= & 0.019^{\star} \mathrm{CP}+0.046 \\ \text { CysMet }= & 0.030^{\star} \mathrm{CP}+0.106 \\ \text { Thr }= & 0.026^{\star} \mathrm{CP}+0.067 \\ \text { Trp }= & 0.008^{\star} \mathrm{CP}+0.031 \\ \text { lle }= & 0.024^{\star} \mathrm{CP}+0.082 \\ \text { Leu }= & 0.067^{\star} \mathrm{CP}-0.011 \\ \text { Val }= & 0.040^{\star} \mathrm{CP}+0.051 \\ \text { Arg }= & 0.044^{\star} \mathrm{CP}+0.079 \\ \text { His }= & 0.027^{\star} \mathrm{CP}-0.007 \\ \text { Phe }= & 0.052^{*} \mathrm{CP}-0.066 \\ \text { Tyr }= & 0.028^{\star} \mathrm{CP}+0.005 \\ \text { Gly }= & 0.035^{\star} \mathrm{CP}+0.089 \\ \text { Ser }= & 0.043^{\star} \mathrm{CP}+0.024 \\ \text { Pro }= & 0.120^{\star} \mathrm{CP}-0.294 \\ \text { Ala }= & 0.030^{\star} \mathrm{CP}+0.119 \\ \text { Asp }= & 0.050^{\star} \mathrm{CP}+0.157 \\ \text { Glu }= & 0.354^{*} \mathrm{CP}-1.03\end{array}$

\section{Field bean}

Lys $=$

Met $=$

Cys =

CysMet =

$\mathrm{Thr}=$

$\operatorname{Trp}=$

Ile $=$

Leu $=$

$\mathrm{Val}=$

Arg =

His =

Phe =

Tyr =

Gly =

Ser $=$

Pro $=$

$\mathrm{Ala}=$

Asp $=$

Glu =

$0.023^{*} \mathrm{CP}+1.206$

ns

ns

ns

$0.020 * \mathrm{CP}+0.416$

$0.006^{*} \mathrm{CP}+0.060$

$0.026^{*} \mathrm{CP}+0.369$

$0.047^{\star} \mathrm{CP}+0.702$

$0.030 * \mathrm{CP}+0.393$

$0.131^{\star} \mathrm{CP}-1.305$

$0.018^{\star} \mathrm{CP}+0.342$

$0.019^{*} \mathrm{CP}+0.667$

$0.019^{*} \mathrm{CP}+0.300$

$0.030 * \mathrm{CP}+0.336$

$0.027^{\star} \mathrm{CP}+0.512$

$0.021{ }^{*} \mathrm{CP}+0.544$

$0.025^{\star} \mathrm{CP}+0.413$

$0.065^{\star} \mathrm{CP}+1.204$

$0.102{ }^{*} \mathrm{CP}+1.696$

$\begin{array}{ll}\mathrm{R}^{2}=0.51 & \text { Oats } \\ \mathrm{R}^{2}=0.69 & \text { Met }= \\ \mathrm{R}^{2}=0.48 & \text { Cys }= \\ \mathrm{R}^{2}=0.60 & \text { CysMet }= \\ \mathrm{R}^{2}=0.93 & \text { Thr }= \\ \mathrm{R}^{2}=0.84 & \text { Trp }= \\ \mathrm{R}^{2}=0.89 & \text { lle }= \\ \mathrm{R}^{2}=0.94 & \text { Leu }= \\ \mathrm{R}^{2}=0.90 & \text { Val }= \\ \mathrm{R}^{2}=0.91 & \text { Arg }= \\ \mathrm{R}^{2}=0.82 & \text { His }= \\ \mathrm{R}^{2}=0.95 & \text { Phe }= \\ \mathrm{R}^{2}=0.92 & \text { Tyr }= \\ \mathrm{R}^{2}=0.94 & \text { Gly }= \\ \mathrm{R}^{2}=0.92 & \text { Ser }= \\ \mathrm{R}^{2}=0.94 & \text { Pro }= \\ \mathrm{R}^{2}=0.91 & \text { Ala }= \\ \mathrm{R}^{2}=0.87 & \text { Asp }= \\ \mathrm{R}^{2}=0.95 & \text { Glu }=\end{array}$

$\mathrm{R}^{2}=0.72$

$R^{2}=0.65$

$\mathrm{R}^{2}=0.57$

$R^{2}=0.62$

$\mathrm{R}^{2}=0.78$

$\mathrm{R}^{2}=0.73$

$R^{2}=0.69$

$R^{2}=0.85$

$R^{2}=0.88$

$R^{2}=0.83$

$R^{2}=0.80$

$\mathrm{R}^{2}=0.90$

$\mathrm{R}^{2}=0.85$

$R^{2}=0.81$

$R^{2}=0.83$

$\mathrm{R}^{2}=0.90$

$\mathrm{R}^{2}=0.78$

$R^{2}=0.76$

$R^{2}=0.90$
$\mathrm{R}^{2}=0.12$

$\mathrm{R}^{2}=0.20$

$\mathrm{R}^{2}=0.52$

$R^{2}=0.45$

$R^{2}=0.43$

$R^{2}=0.45$

$\mathrm{R}^{2}=0.72$

$\mathrm{R}^{2}=0.21$

$R^{2}=0.14$

$R^{2}=0.31$

$R^{2}=0.49$

$\mathrm{R}^{2}=0.27$

$R^{2}=0.26$

$R^{2}=0.44$

$R^{2}=0.39$

$\mathrm{R}^{2}=0.38$

\section{Field pea}

Lys =

Met $=$

Cys =

CysMet =

Thr $=$

$\operatorname{Trp}=$

Ile =

Leu $=$

$\mathrm{Val}=$

Arg $=$

His =

Phe $=$

Tyr =

Gly =

Ser $=$

Pro =

$\mathrm{Ala}=$

Asp =

Glu =

\section{Blue lupin}

Lys =

Met $=$

Cys =

CysMet =

Thr $=$

$\operatorname{Trp}=$

Ile =

Leu $=$

Val =

Arg =

$\mathrm{His}=$

Phe =

Tyr =

Gly =

Ser $=$

Pro =

$\mathrm{Ala}=$

Asp $=$

Glu =
$0.039^{*} \mathrm{CP}+0.059$

$0.015^{\star} \mathrm{CP}+0.025$

$0.017^{\star} \mathrm{CP}+0.150$

$0.032^{*} \mathrm{CP}+0.178$

$0.031^{*} \mathrm{CP}+0.042$

$0.013^{*} \mathrm{CP}+0.011$

$0.038^{*} \mathrm{CP}-0.018$

$0.071^{*} \mathrm{CP}+0.004$

$0.048^{*} \mathrm{CP}+0.009$

$0.065^{\star} \mathrm{CP}+0.012$

$0.023^{*} \mathrm{CP}+0.048$

$0.055^{\star} \mathrm{CP}-0.058$

$0.031{ }^{*} \mathrm{CP}+0.015$

$0.038^{*} \mathrm{CP}+0.126$

$0.043^{*} \mathrm{CP}+0.048$

$0.040 * \mathrm{CP}+0.119$

$0.040 * \mathrm{CP}+0.084$

$0.082^{*} \mathrm{CP}+0.001$

$0.203^{*} \mathrm{CP}-0.071$

$0.068^{*} \mathrm{CP}+0.297$

$0.006^{*} \mathrm{CP}+0.096$

$0.010^{*} \mathrm{CP}+0.076$

$0.016^{*} \mathrm{CP}+0.175$

$0.032^{*} \mathrm{CP}+0.166$

$0.008^{*} \mathrm{CP}+0.029$

$0.036^{\star} \mathrm{CP}+0.128$

$0.067^{\star} \mathrm{CP}+0.107$

$0.041^{*} \mathrm{CP}+0.124$

$0.104^{*} \mathrm{CP}-0.580$

$0.041{ }^{\star} \mathrm{CP}-0.179$

$0.049{ }^{*} \mathrm{CP}+0.017$

$0.030^{*} \mathrm{CP}+0.039$

$0.039^{*} \mathrm{CP}+0.145$

$0.046^{*} \mathrm{CP}+0.038$

$0.033^{*} \mathrm{CP}+0.206$

$0.036^{*} \mathrm{CP}+0.189$

$0.109^{*} \mathrm{CP}+0.234$

$0.167^{*} \mathrm{CP}-0.001$

$0.032 * \mathrm{CP}+0.607$

ns

ns

ns

$0.025^{\star} \mathrm{CP}+0.357$

$0.005^{\star} \mathrm{CP}+0.105$

$0.037^{\star} \mathrm{CP}+0.090$

$0.053^{*} \mathrm{CP}+0.498$

$0.029 * \mathrm{CP}+0.327$

$0.149^{*} \mathrm{CP}-1.404$

$0.066^{\star} \mathrm{CP}-0.887$

$0.038^{*} \mathrm{CP}+0.081$

$0.032{ }^{*} \mathrm{CP}+0.050$

$0.036^{*} \mathrm{CP}+0.209$

$0.049^{*} \mathrm{CP}+0.001$

$0.040 * \mathrm{CP}+0.093$

$0.021{ }^{*} \mathrm{CP}+0.434$

$0.091^{*} \mathrm{CP}+0.384$

$0.223^{*} \mathrm{CP}-0.258$
$\mathrm{R}^{2}=0.80$

$\mathrm{R}^{2}=0.69$

$R^{2}=0.34$

$\mathrm{R}^{2}=0.53$

$\mathrm{R}^{2}=0.80$

$\mathrm{R}^{2}=0.90$

$\mathrm{R}^{2}=0.77$

$R^{2}=0.83$

$R^{2}=0.76$

$R^{2}=0.76$

$R^{2}=0.42$

$\mathrm{R}^{2}=0.79$

$\mathrm{R}^{2}=0.78$

$\mathrm{R}^{2}=0.73$

$\mathrm{R}^{2}=0.72$

$\mathrm{R}^{2}=0.60$

$R^{2}=0.79$

$\mathrm{R}^{2}=0.80$

$\mathrm{R}^{2}=0.76$

$R^{2}=0.49$

$\mathrm{R}^{2}=0.34$

$\mathrm{R}^{2}=0.23$

$R^{2}=0.29$

$R^{2}=0.88$

$\mathrm{R}^{2}=0.48$

$R^{2}=0.81$

$R^{2}=0.87$

$R^{2}=0.85$

$R^{2}=0.82$

$\mathrm{R}^{2}=0.32$

$\mathrm{R}^{2}=0.79$

$\mathrm{R}^{2}=0.80$

$R^{2}=0.88$

$R^{2}=0.79$

$\mathrm{R}^{2}=0.74$

$\mathrm{R}^{2}=0.90$

$R^{2}=0.74$

$R^{2}=0.88$

$R^{2}=0.67$

$R^{2}=0.58$

$R^{2}=0.53$

$\mathrm{R}^{2}=0.90$

$R^{2}=0.88$

$R^{2}=0.82$

$\mathrm{R}^{2}=0.94$

$\mathrm{R}^{2}=0.68$

$\mathrm{R}^{2}=0.84$

$R^{2}=0.82$

$R^{2}=0.86$

$\mathrm{R}^{2}=0.85$

$R^{2}=0.80$

$R^{2}=0.66$

$\mathrm{R}^{2}=0.84$

$R^{2}=0.88$ 
The factors variety, harvest year, and harvest site or area affected the nutrient composition of the cultivars differently (Table I 8). There was only one model with variety as the only factor (Phe in spring wheat). Tyr, Arg, and His contents of spring wheat as well as CF and EE contents of winter barley were not affected by the test factors. Information on the F-and p-values of the anova for each model and on the Ismeans and standard errors of factor manifestations can be found in the Appendix (Tables A I 1-25).

Table I 8: Factors affecting the content ( $\mathrm{g} / \mathrm{kg} \mathrm{DM})$ of crude nutrients and amino acids in selected cereals and grain legumes

\begin{tabular}{|c|c|c|c|c|c|c|c|c|c|c|}
\hline & WW & SW & WR & WT & WB & SB & 0 & FP & FB & $\mathrm{BL}$ \\
\hline $\mathrm{n}$ & 70 & 25 & 81 & 92 & 15 & 47 & 80 & 41 & 57 & 31 \\
\hline $\mathrm{CP}$ & $(\mathrm{A})$ & VY & SY & AY & $S$ & VA & VSY & SY & $\mathrm{VA}(\mathrm{Y})$ & VSY \\
\hline EE & VY & $Y$ & VY & VY & & (A) & VS & VSY & $\mathrm{V}(\mathrm{Y})$ & VSY \\
\hline$\overline{C A}$ & $Y$ & $Y$ & VY & VAY & $S$ & AY & SY & $S(Y)$ & $V^{\prime}$ & $S$ \\
\hline $\mathrm{CF}$ & VAY & (A) & VY & VA & & A & SY & SY & VAY & VY \\
\hline $\mathrm{NfE}$ & VY & VY & SY & A & $S$ & VA & SY & VSY & VA & VSY \\
\hline Starch & VY & $\mathrm{V}(\mathrm{A}) \mathrm{Y}$ & VSY & VAY & $S$ & $A(Y)$ & SY & VS & VAY & VS \\
\hline Lys & VAY & (Y) & VSY & VAY & $S$ & VAY & VS & SY & VY & S \\
\hline Met & (Y) & $Y$ & SY & VAY & $S$ & $A Y$ & VS & $\mathrm{S}$ & VY & $Y$ \\
\hline Cys & (A) $Y$ & VY & SY & VAY & S & VAY & VSY & SY & AY & Y \\
\hline Thr & VY & Y & SY & $A Y$ & $S$ & AY & VSY & $\mathrm{S}(\mathrm{Y})$ & VY & $S$ \\
\hline Trp & $Y$ & VY & * & * & $S$ & A & * & SY & VY & $S$ \\
\hline lle & VY & VY & SY & $A Y$ & $S$ & VA & VSY & SY & VAY & VS \\
\hline Leu & VY & VY & SY & VAY & $S$ & VA & VSY & SY & VAY & VS \\
\hline Val & VY & VY & SY & VAY & S & VA & VS & $S(Y)$ & VAY & VS \\
\hline Arg & VAY & & SY & VAY & $S$ & VA & VSY & SY' & VA & VS \\
\hline His & VY & & SY & VAY & $S$ & $A Y$ & VSY & SY & $A(Y)$ & $\mathrm{V}(\mathrm{Y})$ \\
\hline Phe & $Y$ & V & SY & $A Y$ & $S$ & VA & VSY & $S$ & $A Y^{\prime}$ & $S$ \\
\hline Tyr & VY & & VSY & VAY & S & VA & VS & S & AY & VS \\
\hline Ala & VY & $\bar{Y}$ & SY & $A Y$ & $S$ & VA & VSY & VSY & VY & S \\
\hline Gly & $V(A) Y$ & $Y$ & VSY & VAY & $S$ & VA & VS & VSY & VA & $S$ \\
\hline Ser & VAY & $Y$ & SY & $A Y$ & $S$ & VA & VSY & $S$ & VA & VS \\
\hline Pro & $Y$ & VY & VSY & AY & $S$ & VA & VS & VSY & VAY & $S$ \\
\hline Asp & $Y$ & $Y$ & VSY & AY & S & VAY & VS & SY & $\mathrm{VA}(\mathrm{Y})$ & VS \\
\hline Glu & $Y$ & VY & VSY & AY & S & VA & VSY & $S(Y)$ & VAY & VS \\
\hline $\begin{array}{l}\mathrm{C} \\
\mathrm{Tr} \\
\mathrm{Ty} \\
\mathrm{ac} \\
\mathrm{we}\end{array}$ & $\begin{array}{l}=\text { crud } \\
=\text { trypt } \\
=\text { tyros } \\
\text {; Glu = } \\
\text { e part o }\end{array}$ & $\begin{array}{l}\text {; SW = } \\
\text { ats; FP } \\
\text { ash; CF } \\
\text { ohan; Ile } \\
\text { e; Arg = } \\
\text { lutamic } \\
\text { he glm }\end{array}$ & $\begin{array}{l}\text { isole } \\
\text { rginine } \\
\text { id; } A= \\
\text { hough }\end{array}$ & $\begin{array}{l}; \text { Lel } \\
=\text { al } \\
\text { a V }= \\
\text { effec }\end{array}$ & $\begin{array}{l}\text { eucin } \\
\text { e; Gly } \\
\text { iety; }\end{array}$ & $\begin{array}{l}\text { lal = } \\
\text { glycine } \\
\text { harves } \\
\text { tatistic }\end{array}$ & $\begin{array}{l}\text { er tritic } \\
\text { oin; CF } \\
\text { onine } \\
\text { ine; H } \\
\text { Ser = } \\
\text { ite; } Y \\
\text { y signi }\end{array}$ & $\begin{array}{l}\text {;WB } \\
\text { crude } \\
\text { et }=n \\
=\text { histic } \\
\text { ne; Pr } \\
\text { ear; fa } \\
\text { nt; }{ }^{*} \text { nu }\end{array}$ & $\begin{array}{l}\text { er barle } \\
\text { in; EE } \\
\text { onine; } \\
\text { Phe = } \\
\text { roline; } \\
\text { illustrat }\end{array}$ & $\begin{array}{l}=\text { Spr } \\
\text { Cystra } \\
\text { Cysti } \\
\text { ylalani } \\
=\text { aspa } \\
\text { brack }\end{array}$ \\
\hline
\end{tabular}

The $\mathrm{CN}$ and $\mathrm{AA}$ contents of cereals and grain legumes were mainly affected by the factors year and site or area. However, the variety was the main factor affecting EE contents in spring barley and oats and CF contents in winter wheat, winter rye, and winter triticale. Furthermore, it mainly affected Arg contents in winter wheat, spring barley, and field beans, Ala and Val contents in spring barley, Leu, Ile, Phe, and Pro contents in spring wheat, and Ala, Asp, and Glu contents in field beans.

Generally, CP and starch or NfE contents were affected inversely. Although the CP content of winter wheat was not affected by the variety, harvest area, or harvest year, the content of some AA was affected. Naturastar had significantly higher Lys, Thr, Leu, Val, Arg, His, Tyr, Ala, Gly, and Ser contents than the other two winter wheat varieties. Furthermore, the Lys content of winter wheat was lower in samples taken in area 2 than in area 3. In spring 
wheat, the variety and year had an impact on the content of CP and simultaneously on several AA. In winter rye and winter triticale, the variety had no influence on the CP content. However, the effect of the variety on the contents of some AA, including Lys, was observed. The winter rye variety Palazzo contained low amounts of Lys, Tyr, Gly, Ser, Asp, and Glu. The winter triticale variety Cosinus had high contents of Lys, Met, Cys, Leu, Arg, His, Tyr, and Gly. Harvest year and site affected the contents of $\mathrm{CP}, \mathrm{NfE}$, starch, and all AA in winter rye, while the variety and year affected EE, CA, and CF contents. The variety had no effect on the nutrient composition of winter barley. However, the cultivation environment affected the contents of $\mathrm{CP}, \mathrm{CA}, \mathrm{NfE}$, starch, and all AA. The spring barley varieties Grace and Marthe contained low amounts of NfE but high amounts of CP and AA. In 2011, high contents of the SAA, Thr, His, and Asp were observed in these two cultivars. In addition, the effect of the area was small. The oat variety Ivory contained high amounts of CP and AA. Although the effect of the year was small in oats, in 2012 Cys contents were higher and contents of Leu, Arg, His, Phe, and Ser were lower than in the other two years. The samples harvested on two sites in area 1 contained significant amounts of $C P$ and $A A$. While environmental conditions affected the content of all nutrients in field peas, variety had no effect on the contents of CP, CA, CF, and most of the AA. In 2012, starch and His contents in field peas were low, while CP, Lys, Cys, and lle contents were high. In field beans, the variety did not affect all $A A$ contents. However, there were shifts in the ranking of the $A A$ contents between the varieties. In blue lupine, the contents of the CP and the affected AA (Table A I 25) were high in the variety Probor. The SAA were contained in higher amounts in samples harvested in 2011 than in 2012. The other AA contents were affected by the harvest site.

\section{Discussion}

In the present study, the contents of all nutrients varied widely in all cultivars (Table I 3-6). Wide variations of the $\mathrm{CN}$ and $\mathrm{AA}$ contents have already been described for conventionally and organically produced cereals (DLG 2006-2010, Rodehutscord et al. 2016) and grain legumes (DLG 2006-2010, Jezierny et al. 2011, Kyntäjä et al. 2014). They can be seen when comparing different feed value tables (e. g., Ajinomoto Animal Nutrition Group 20032013, DLG 2006-2010, Bryden et al. 2009, Agroscope 2011-2016, Ajinomoto Animal Nutrition Group 2014, DLG 2014, Kyntäjä et al. 2014, Evonik 2016, Blok \& Dekker 2017, INRA-CIRAD-AFZ 2018). Depending on the origin and the size of the sample set, the mean content as well as the minimum and maximum content of a nutrient can differ between feed value tables. In an overall comparison, the contents of EE, CA, and CF determined in the present study were within the range of the existing table values. However, the minimum content of $\mathrm{CP}$ in rye, spring barley, and winter triticale was about 1.7, 0.1 , and $1.0 \%$ lower than the minimum content reported by Evonik (2016), who reported the lowest and highest 
contents, respectively. Additionally, the maximum starch contents of winter triticale and spring wheat were about 1.2 and $0.7 \%$ higher than reported by Evonik (2016). While the mean CF and EE contents of most cultivars were comparable to the table values, blue lupins and field peas contained high amounts of CF, while the EE content of oats was low compared to INRA-CIRAD-AFZ (2018), Evonik (2016) and Agroscope (2011-2016). Furthermore, the mean CP contents of the cereals, field peas, and blue lupins tended to be lower than table values, while mean starch contents tended to be higher in those cultivars with the exception of wheat (e. g., (Agroscope 2011-2016, Evonik 2016, Rodehutscord et al. 2016). A connection between starch and CP contents, which has been previously described by Kim et al. (2003), can be due to nutrient shifts during ripening or can be genetically determined (Hughes et al. 2001). Dangour et al. (2009) conducted a metaanalysis with 42 studies and found that $N$ contents were on average $6.7 \%$ lower in organically than in conventionally produced foodstuffs. However, they did not observe systematic differences in specific proteins or carbohydrates.

It is striking that in most feed tables winter and spring forms of the cultivars are not declared, although the present study showed differences. Similarly to the tables provided by Evonik (2016), higher CP and starch contents as well as lower CF contents were determined for spring barley in the present study. However, DLG (2014) conversely reported lower CP contents and higher CF contents in spring barley varieties. The values of the DLG (2014) feed tables specified also the differences between spring and winter forms of wheat. Although DLG (2014) reported higher CP and lower starch contents, the EE, CA, and CF contents and the direction of the deviations between spring and winter wheat were comparable to the present findings.

There are table values that report the AA content of single feedstuffs and AA contents in the CP of single feedstuffs (e. g., Ajinomoto Animal Nutrition Group 2003-2013, Bryden et al. 2009, Agroscope 2011-2016, Evonik 2016, Blok \& Dekker 2017, INRA-CIRAD-AFZ 2018). Evonik (2016) also reported mean ratios of the essential AA to Lys. The AA contents of all samples of winter wheat and oats were within reported ranges (Ajinomoto Animal Nutrition Group 2003-2013, Agroscope 2011-2016, Evonik 2016, INRA-CIRAD-AFZ 2018). However, the minimum content of all $A A$ in winter rye and winter triticale and of most amino acids in barley and field peas of the present study was below the minimum table values. The minimum content of Cys and Thr in field beans and the minimum content of Trp and lle in blue lupins was lower than the minimum content of these AA reported in feed tables. Furthermore, their maximum His content exceeded the maximum content described in feed tables. The mean His content of wheat, winter rye, oats, and the grain legume cultivars was higher than reported in feed tables. In barley, the contents of all AA and in winter triticale the contents of all AA except for His were lower than reported in feed tables. Although Lys 
and Met contents in the other cultivars were comparable to the contents reported in feed tables, the contents of the several AA, essential and non-essential, were lower in the sample set of the present study.

The concentration of the $A A$ in the crude protein of the organic cereals and grain legumes of the present study varied wider than values reported in feed tables (Ajinomoto Animal Nutrition Group 2003-2013, Agroscope 2011-2016, Evonik 2016, INRA-CIRAD-AFZ 2018). The mean concentration of the AA in the CP were mostly similar in the present study and in feed tables. However, high concentrations of Lys and His led in most cereals and grain legumes to a high ratio of His and a low ratio of most of the other AA to Lys, when compared to Evonik (2016). Compared to ratios reported in feed tables, the ratio of the sulphurcontaining amino acids that are reported to be limiting in common diets for monogastric animals in organic farming was higher in wheat and comparable or slightly lower in the other cultivars.

The AA composition in crops can vary widely and depends on the occurrence of various protein fractions (e. g., albumins, globulins, glutenins, and gliadins), which are specific for each cultivar. The proportion of protein fractions can differ between grain samples depending on the environmental conditions of the year (Casey \& Short 1981, Casey et al. 1982, Hanell et al. 2004) and variety (O'Kane et al. 2006). For example, albumins and globulins are low in Pro and Glu but high in Arg, Lys, and Asp, while prolamins or the storage proteins gliadin and glutenin are high in Pro and Glu but low in Lys, Thr, and Trp (Draper 1973, Simpson 2001, Shewry \& Halford 2002, Shewry 2007). Legumin is a storage protein fraction in grain legumes and contains large amounts of amides, including Arg, Asp, and Glu (Derbyshire et al. 1976). Vicillin contains high levels of Ile, Leu, and Lys (Jackson et al. 1969, Rubio et al. 2013). The correlations between AA and CP contents that were observed in the present study can be a result of shifts between protein fractions. The CP content of cereals was positively correlated with Glu and Pro contents in the CP indicating that more prolamins are contained in the CP. In grain legumes, the Arg content increased with increasing protein contents in the grain indicating that legumin contents were enhanced and vicillin fractions diminished. This was in accordance with findings of Gueguen \& Barbot (1988) and Casey et al. (1982), who found Met and Cys contents of peas rising when the legumin:vicillin ratio increased. The increase and decrease of specific proteins led to an altered AA profile of the CP. Thus, the AA ratio of the feedstuff was also affected. This must be considered in diet formulation along with the fact that the dietary $C P$ level and the AA balance can affect the optimal Lys level for performance (Abdel-Maksoud et al. 2010).

Most of the equations derived from regression analyses had a high coefficient of determination indicating that they can be used to predict the AA contents on the basis of the result of CP analysis. This practice is already common in practical feed evaluation in 
Germany. The German Agricultural Analytic and Research Institutes (VDLUFA) provide information on the AA contents in different feedstuffs obtained using the available equations provided by Evonik (2016). Despite some deviations where AA contents would be slightly overestimated, the results obtained using the currently available equations (Evonik 2016) were generally comparable to the values calculated with the equations derived from the present sample set (example in Figure I 1). Thus, equations are valuable tools, which can be used to calculate approximate AA contents, when the CP content of cereals and grain legumes is known.
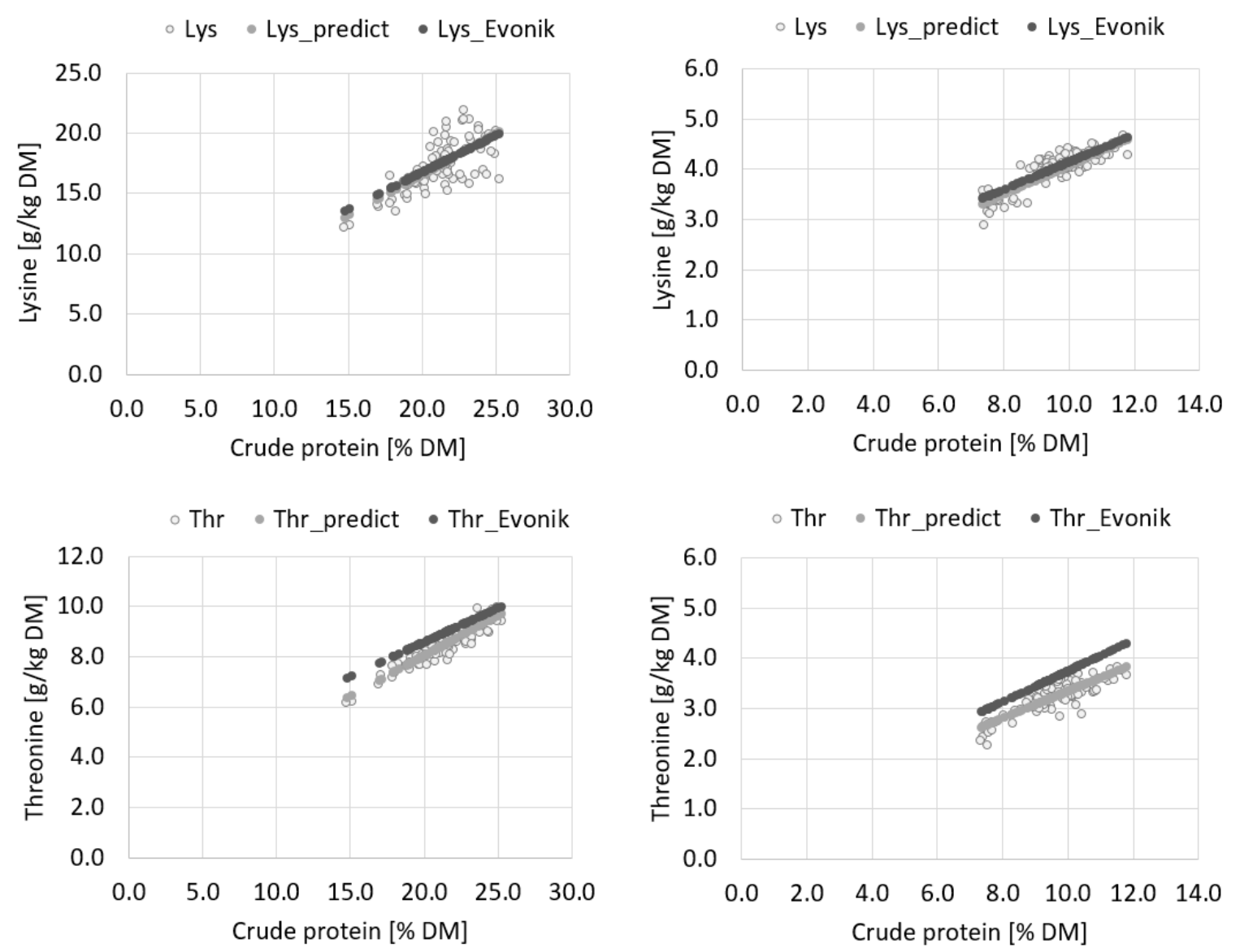

Figure I 1: Contents of lysine and threonine in field peas (left) and barley (right) determined by HPLC and predicted by the equations developed in the present study (_predict) and AminoDat 5.0 (_Evonik, Evonik 2016)

The AA composition of field beans cannot be predicted using the equations from the present study. However, the equations from Evonik (2016) provided satisfying coefficients of determinations (157 samples) and thus can be used to predict it, although the goodness of the prediction is better in the equations for the other grain legumes as well as in the equations for cereals. The SAA amounts contained in blue lupins, field beans, and field peas cannot be predicted satisfactorily as yet. A less accurate prediction of Lys, like in wheat, field peas, and rye in the present study, can have consequences in diet formulation when the IAAR (ideal amino acid ratio) concept with Lys as the reference AA is applied. Additionally, since the SAA are often limiting in common organic diets (Sundrum 2001, Blair 
2008), their prediction should be improved as well. The decreased predictability might be due to wider variations in the crops or to less accurate analysis results for the SAA (Rubio et al. 2013).

Several studies found an effect of the variety and the environmental conditions during cultivation and storage on the nutrient composition of grains of different cereal and grain legume cultivars. Environmental conditions can include cultivation management, which can substantially differ between cultivation sites and years. For example, Gronle (2014) reported that the crop stand as well as the cultivation technique had an influence on the CN composition of field peas. Climate and soil conditions can also add to the environmental effect. Nikolopoulou et al. (2007) concluded that these two factors are the main reason for differences in the nutrient composition of field peas. The variety and site can also affect the NfE composition of wheat (Longstaff \& McNab 1986, Shewry et al. 2010). The effect of the harvest year on the nutrient composition of cereals and grain legumes was strong in the present study. This was also reported by (Kim et al. 2003), who found the nutrient composition of wheat to be affected by the variety and harvest year and concluded that the annual precipitation level can be a major influence. Metayer et al. (1993) analysed the nutrient composition of a selection of cereals and found that the harvest site and year affected the nutrient composition of their cereals.

Even the AA contents were affected by the variety and environmental conditions. The influence of the environment, i. e. the cultivation management and climate conditions, was described in earlier studies. Nitrogen fertilisation does for example have an impact on the AA composition of different barley varieties (Jørgensen et al. 1999) and the AA composition in field beans can vary not only between harvest years but also between varieties (Kotlarz et al. 2011). The effect of the factor variety can be due to the fact that high CP yield is a major breeding aim. Varieties that have the potential to have high CP yields most likely differ in their CP composition from varieties without this characteristic. Wheat that is bred for human or animal nutrition, respectively, is one example for systematic differences between breeding lines. Although every wheat variety can be used as a feedstuff, varieties with good baking qualities often contain more glutenin and less albumin and globulin, which are contained in varieties cultivated for animal feeding (Krejčírová et al. 2006, Krejčirrová et al. 2007). The winter varieties that were analysed and compared in the present study are wheat varieties with good baking quality. They did not differ in their CP content. However, the highquality variety Naturastar had significantly lower contents of Lys, Thr, Leu, Arg, His, Tyr, Ala, Gly, and Ser than the elite-quality varieties Butaro and Capo. This result is in general accordance with the above reported results.

When compared to reported concentrations of $A A$ in the $\mathrm{CP}$ of organically produced cereals and grain legumes from Germany, UK and Finland (DLG 2006-2010, Kyntäjä et al. 2014), 
it became obvious that the environmental conditions have effects within the production system.

The reported genetic variability obviously depends on the choice of varieties and on genotype-environment interactions. The effects of the harvest year and site are most likely a combination of weather conditions, soil conditions, and cultivation management. This was also observed in the present study. In most cases, the occurrence of differences in the nutrient composition seemed to be random. That is partly because of a lack of knowledge with regard to the underlying cultivation conditions and partly because the interactions between genetic and environmental factors are often difficult to comprehend. In general, the environmental conditions had a larger impact on the nutrient content than the variety (Appendix Table A I 1-5). Yet, CF contents of wheat, rye, and triticale and EE contents of oats were largely affected by the variety. Thus, breeding progress could have had an effect and can probably lead to further alterations of the content of the named nutrients (Murphy et al. 2009).

\section{Conclusions}

The contents of $\mathrm{CN}$ and $\mathrm{AA}$ in organically produced cereals and grain legumes vary widely and depend on the variety and environmental conditions. When comparing table values that describe the nutrient composition of feedstuffs, it becomes clear that a comparison of mean values is deceptive and the use of table values in animal nutrition is misleading. Many tables contain the minimum and maximum values for nutrient contents. This practice allows a general characterisation of feedstuffs. However, it is not possible to predict the amount of $\mathrm{CN}$ in feedstuffs even when the variety, the cultivation site, and the harvest year are known. Since variations in the $C N$ and $A A$ composition must be considered in diet formulation, it is recommended to analyse the $\mathrm{CN}$ composition of each batch of a feedstuff.

Changes in the CP contents of cereals and grain legumes are accompanied by an altered AA profile. The content of Glu, Pro, and Phe in cereals and Arg in grain legumes increase with increasing CP contents. Thus, the prediction of the AA contents from the CP content is considered a suitable technique and can be applied in practical diet formulation. However, the equations for the prediction need to be further improved using additional analysis results. 


\section{References}

Abdel-Maksoud, A., Yan, F., Cerrato, S., Coto, C., Wang, Z.L. and Waldroup, P.W. (2010). Effect of Dietary Crude Protein, Lysine Level and Amino Acid Balance on Performance of Broilers 0 to 18 Days of Age. Int J Poult Sci 9, 21-27. ISSN: 1682-8356

Agroscope (2011-2016). Feedbase - the Swiss Feed Database, https://www.feedbase.ch/, University of Zurich, Agroscope. Last access 25th of June 2018.

Ajinomoto Animal Nutrition Group (2003-2013). Ajinomoto Heartland (since April 2018 Ajinomoto Animal Nutrition North America) Amino Acid Database, http://aaa.lysine.com/, Last Acces 25th June 2018.

Ajinomoto Animal Nutrition Group (2014). Ajinomoto Eurolysine S.A.S. Laboratory Analysis Database, http://ajinomoto-eurolysine.com/feedstuffs-amino-acid-database.html, Last Access 25th of June 2018.

Blair, R. (2008). Nutrition and Feeding of Organic Poultry. CABI. ISBN: 9781845934064

Blok, M.C. and Dekker, R.A. (2017). Table 'Standardized Ileal Digestibility of Amino Acids in Feedstuffs for Poultry'. Wageningen Livestock Research. DOI: 10.18174/426333

Boisen, S., Hvelplund, T. and Weisbjerg, M.R. (2000). Ideal Amino Acid Profiles as a Basis for Feed Protein Evaluation. Livest Prod Sci 64, 239-251. DOI: 10.1016/S0301-6226(99)00146-3

Brookes, G. and Barfoot, P. (2018a). Environmental Impacts of Genetically Modified (GM) Crop Use 19962016: Impacts on Pesticide Use and Carbon Emissions. GM Crops \& Food, 1-69. DOI: $10.1080 / 21645698.2018 .1476792$

Brookes, G. and Barfoot, P. (2018b). Farm Income and Production Impacts of Using Gm Crop Technology 1996-2016. GM Crops \& Food 9, 59-89. DOI: 10.1080/21645698.2018.1464866

Bryden, W.L., Li, X., Ravindran, G., Hew, L.I. and Ravindran, V. (2009). Ileal Digestible Amino Acid Values in Feedstuffs for Poultry. Rural Industries Research and Development Corporation. ISBN: 1741518709

Burstin, J., Gallardo, K., Mir, R.R., Varshney, R.K. and Duc, G. (2011). Improving Protein Content and Nutrition Quality, In: Pratap, A. (Ed.), Biology and Breeding of Food Legumes, International Crops Research Institutes of the Semi-Arid Tropics.

Calcagno, V. (2013). Glmulti: Model Selection and Multimodel Inference Made Easy. R Package Version 1.0.7. https://cran.R-project.org/package=glmulti.

Casey, R., Sharman, J.E., Wright, D.J., Bacon, J.R. and Guldager, P. (1982). Quantitative Variability in Pisum Seed Globulins: Its Assessment and Significance. Plant Food Hum Nutr 31, 333-346. DOI: 10.1007/BF01094045

Casey, R. and Short, M.N. (1981). Variation in Amino Acid Composition of Legumin from Pisum. Phytochemistry 20, 21-23. DOI: 10.1016/0031-9422(81)85210-7

Cohen, S.A. and Michaud, D.P. (1993). Synthesis of a Fluorescent Derivatizing Reagent, 6-Aminoquinolyl-NHydroxysuccinimidyl Carbamate, and Its Application for the Analysis of Hydrolysate Amino Acids Via HighPerformance Liquid Chromatography. Anal Biochem 211, 279-287. DOI: 10.1006/abio.1993.1270

Dangour, A.D., Dodhia, S.K., Hayter, A., Allen, E., Lock, K. and Uauy, R. (2009). Nutritional Quality of Organic Foods: A Systematic Review. Am J Clin Nutr 90, 680-685. DOI: 10.3945/ajcn.2009.28041

Derbyshire, E., Wright, D.J. and Boulter, D. (1976). Legumin and Vicilin, Storage Proteins of Legume Seeds. Phytochemistry 15, 3-24. DOI: 10.1016/S0031-9422(00)89046-9

DLG (2006-2010). DLG-Datenbank Futtermittel [DLG-Database for Feedstuffs], Deutsche LandwirtschaftsGesellschaft e.V. http://datenbank.futtermittel.net, last access 11th July 2018.

DLG (2014). DLG-Futterwerttabellen Schwein [DLG-Feed Value Tables for Swine]. DLG-Verlag.

Draper, S.R. (1973). Amino Acid Profiles of Chemical and Anatomical Fractions of Oat Grains. J Sci Food Agr 24, 1241-1250. DOI:10.1002/jsfa.2740241013

EC (2007). Council Regulation (EC) No 834/2007 of 28 June 2007 on Organic Production and Labelling of Organic Products and Repealing Regulation (EEC) No 2092/91.

EC (2008). Commission Regulation (EC) No 889/2008 of 5 September 2008 Laying Down Detailed Rules for the Implementation of Council Regulation (EC) No 834/2007 on Organic Production and Labelling of Organic Products with Regard to Organic Production, Labelling and Control.

EC (2009). Commission Regulation (EC) No 152/2009 of 27 January 2009 Laying Down the Methods of Sampling and Analysis for the Official Control of Feed. 
EU (2014). Commision Implementing Regulation (EU) No 836/2014 of 31 July 2014 Amending Regulation (EC) No 889/2008 Laying Down Detailed Rules for the Implementation of Council Regulation (EC) No 834/2007 on Organic Production and Labelling of Organic Products with Regard to Organic Production, Labelling and Control.

Evonik (2016). Evonik Nutrition \& Care Gmbh. Aminodat 5.0, Version 1.03.

Gronle, A. (2014). Agronomic Aspects of Intercropping Spring or Winter Peas and Cereals as Influenced by Ploughing System. Dissertation, University of Kassel.

Gueguen, J. and Barbot, J. (1988). Quantitative and Qualitative Variability of Pea (Pisum Sativum L.) Protein Composition. J Sci Food Agr 42, 209-224. DOI:10.1002/jsfa.2740420304

Hanell, U., L-baeckström, G. and Svensson, G. (2004). Quality Studies on Wheat Grown in Different Cropping Systems: A Holistic Perspective. Acta Agric Scand, Sec B - Soil \& Plant Sci 54, 254-263. DOI: 10.1080/09064710410030302

Hothorn, T., Bretz, F. and Westfall, P. (2008). Simultaneous Inference in General Parametric Models. Biom J 50, 346-363. DOI: 10.1002/bimj.200810425

Hughes, R.K., Desforges, N., Selwood, C., Smith, R., Speirs, C.I., Sinnaeve, G., Gorton, P.G., Wiseman, J., Jumel, K., Harding, S.E., Hill, S.E., Street, V., Wang, T.L. and Hedley, C.L. (2001). Genes Affecting Starch Biosynthesis Exert Pleiotropic Effects on the Protein Content and Composition of Pea Seeds. J Sci Food Agr 81, 877-882. DOI: 10.1002/jsfa.856

INRA-CIRAD-AFZ (2018). INRA-CIRAD-AFZ Feed Tables - Composition and Nutritive Values of Feeds for Cattle, Sheep, Goats, Pigs, Poultry, Rabbits, Horses and Salmonids, https://feedtables.com/, Last Access 1st August 2018.

Jackson, P., Boulter, D. and Thurman, D.A. (1969). A Comparison of Some Properties of Vicilin and Legumin Isolated from Seeds of Pisum Sativum, Vicia Faba and Cicer Arietinum. New Phytologist 68, 25-33. DOI:10.1111/j.1469-8137.1969.tb06416.x

Jezierny, D., Mosenthin, R. and Bauer, E. (2010). The Use of Grain Legumes as a Protein Source in Pig Nutrition: A Review. Anim Feed Sci Tech 157, 111-128. DOI: 10.1016/j.anifeedsci.2010.03.001

Jezierny, D., Mosenthin, R., Sauer, N., Roth, S., Piepho, H.P., Rademacher, M. and Eklund, M. (2011). Chemical Composition and Standardised Ileal Digestibilities of Crude Protein and Amino Acids in Grain Legumes for Growing Pigs. Livest Sci 138, 229-243. DOI: 10.1016/j.livsci.2010.12.024

JKI (2018). Julius-Kühn-Institute, Geoportal, http://geoportal.julius-kuehn.de/map?app=oeko. Last Access: 1st of August 2018.

Jørgensen, H., Gabert, V.M. and Fernández, J.A. (1999). Influence of Nitrogen Fertilization on the Nutritional Value of High-Lysine Barley Determined in Growing Pigs. Anim Feed Sci Tech 79, 79-91. DOI: 10.1016/S0377-8401(99)00011-5

Kim, J.C., Mullan, B.P., Simmins, P.H. and Pluske, J.R. (2003). Variation in the Chemical Composition of Wheats Grown in Western Australia as Influenced by Variety, Growing Region, Season, and Post-Harvest Storage. Aust J Agr Res 54, 541-550. DOI: 10.1071/Ar02183

Kotlarz, A., Sujak, A., Strobel, W. and Grzesiak, W. (2011). Chemical Composition and Nutritive Value of Protein of the Pea Seeds - Effect of Harvesting Year and Variety. Veg Crop Res Bul 75, 57-69. DOI: $10.2478 / v 10032-011-0018-2$

Krejčiřová, L., Capouchová, I., Petr, J., Bicanová, E. and Faměra, O. (2007). The Effect of Organic and Conventional Growing Systems on Quality and Storage Protein Composition of Winter Wheat. Plant Soil Environ 53, 499-505. DOI: 10.17221/2304-Pse

Krejčírová, L., Capouchová, I., Petr, J., Bicanová, E. and Kvapil, R. (2006). Protein Composition of Winter Wheat from Organic and Conventional Farming. Zemdirbyste 93, 285-296. ISSN: 1392-3196

Kyntäjä, A., Partanen, K., Siljander-Rasi, H. and Jalava, T. (2014). Tables of Composition and Nutritional Values of Organically Produced Feed Materials for Pigs and Poultry. . MTT Report 164. ISBN: 978-952-487-571-4

Lenth, R.V. (2016). Least-Squares Means: The R Package Lsmeans. J Stat Softw 69, 1-33. DOI: $10.18637 /$ jss.v069.i01

Longstaff, M. and McNab, J.M. (1986). Influence of Site and Variety on Starch, Hemicellulose and Cellulose Composition of Wheats and Their Digestibilities by Adult Cockerels. Br Poult Sci 27, 435-449. DOI: 10.1080/00071668608416901

Metayer, J.P., Grosjean, F. and Castaing, J. (1993). Study of Variability in French Cereals. Anim Feed Sci Tech 43, 87-108. DOI: 10.1016/0377-8401(93)90145-A

Murphy, K.M., Hoagland, L.A., Reeves, P.G., Baik, B.-K. and Jones, S.S. (2009). Nutritional and Quality Characteristics Expressed in 31 Perennial Wheat Breeding Lines. Renew Agr Food Syst 24, 285-292. DOI: $10.1017 / S 1742170509990159$ 
Nikolopoulou, D., Grigorakis, K., Stasini, M., Alexis, M.N. and lliadis, K. (2007). Differences in Chemical Composition of Field Pea (Pisum Sativum) Cultivars: Effects of Cultivation Area and Year. Food Chem 103, 847-852. DOI: 10.1016/j.foodchem.2006.09.035

O'Kane, F.E., Vereijken, J.M., Gruppen, H. and Boekel, M.A.J.S. (2006). Gelation Behavior of Protein Isolates Extracted from 5 Cultivars of Pisum Sativum L. J Food Sci 70, C132-C137. DOI: 10.1111/j.1365-2621.2005.tb07073.x

Peoples, M.B., Brockwell, J., Herridge, D.F., Rochester, I.J., Alves, B.J.R., Urquiaga, S., Boddey, R.M., Dakora, F.D., Bhattarai, S., Maskey, S.L., Sampet, C., Rerkasem, B., Khan, D.F., Hauggaard-Nielsen, H. and Jensen, E.S. (2009). The Contributions of Nitrogen-Fixing Crop Legumes to the Productivity of Agricultural Systems. Symbiosis 48, 1-17. DOI: 10.1007/bf03179980

Peterson, B.G. and Carl, P. (2014). Performanceanalytics: Econometric Tools for Performance and Risk Analysis. R Package Version 1.4.3541.

R Core Team (2017). R: A Language and Environment for Statistical Computing, Version 3.4.0. http://www.Rproject.org/, R Foundation for Statistical Computing, Vienna, Austria.

Rodehutscord, M., Rückert, C., Maurer, H.P., Schenkel, H., Schipprack, W., Bach Knudsen, K.E., Schollenberger, M., Laux, M., Eklund, M., Siegert, W. and Mosenthin, R. (2016). Variation in Chemical Composition and Physical Characteristics of Cereal Grains from Different Genotypes. Arch Anim Nutr 70, 87-107. DOI: 10.1080/1745039X.2015.1133111

Rubio, L.A., Pérez, A., Ruiz, R., Guzmán, M.Á., Aranda-Olmedo, I. and Clemente, A. (2013). Characterization of Pea (Pisum Sativum) Seed Protein Fractions. J Sci Food Agr 94, 280-287. DOI:10.1002/jsfa.6250

Shewry, P.R. (2007). Improving the Protein Content and Composition of Cereal Grain. J Cereal Sci 46, 239250. DOI: $10.1016 /$ j.jcs.2007.06.006

Shewry, P.R. and Halford, N.G. (2002). Cereal Seed Storage Proteins: Structures, Properties and Role in Grain Utilization. J Exp Bot 53, 947-958. DOI: 10.1093/jexbot/53.370.947

Shewry, P.R., Piironen, V., Lampi, A.-M., Edelmann, M., Kariluoto, S., Nurmi, T., Fernandez-Orozco, R., Andersson, A.A.M., Åman, P., Fraś, A., Boros, D., Gebruers, K., Dornez, E., Courtin, C.M., Delcour, J.A., Ravel, C., Charmet, G., Rakszegi, M., Bedo, Z. and Ward, J.L. (2010). Effects of Genotype and Environment on the Content and Composition of Phytochemicals and Dietary Fiber Components in Rye in the Healthgrain Diversity Screen. J Agric Food Chem 58, 9372-9383. DOI: 10.1021/jf100053d

Shewry, P.R., Van Schaik, F., Ravel, C., Charmet, G., Rakszegi, M., Bedo, Z. and Ward, J.L. (2011). Genotype and Environment Effects on the Contents of Vitamins B1, B2, B3, and B6 in Wheat Grain. J Agr Food Chem 59, 10564-10571. DOI: 10.1021/jf202762b

Simpson, D.J. (2001). Proteolytic Degradation of Cereal Prolamins-the Problem with Proline. Plant Science 161, 825-838. DOI: 10.1016/S0168-9452(01)00482-4

Stockdale, E.A., Shepherd, M.A., Fortune, S. and Cuttle, S.P. (2006). Soil Fertility in Organic Farming Systems - Fundamentally Different? Soil Use Manage 18, 301-308. DOI: 10.1111/j.1475-2743.2002.tb00272.x

Sundrum, A. (2001). Managing Amino Acids in Organic Pig Diets, Proceedings of the 4th NAHWOA-Workshop, 24-27.03.2001, Wageningen, NL (2001), pp. 181-191.

Teuscher, P., Grüninger, B. and Ferdinand, N. (2005). Risk Management in Sustainable Supply Chain Management (SSCM): Lessons Learnt from the Case of Gmo-Free Soybeans. Corp Soc Responsib Environ Mgmt 13, 1-10. DOI: 10.1002/csr.81

VDLUFA (2012). VDLUFA Methodenbuch Band III Die Chemische Untersuchung von Futtermitteln einschl. 1.8. Ergänzungslieferung [VDLUFA Method Book Volume III The Chemical Analyses of Feedstuffs incl. 1st8th Supplemental Delivery], VDLUFA Verlag, Darmstadt.

Watson, C.A., Atkinson, D., Gosling, P., Jackson, L.R. and Rayns, F.W. (2006). Managing Soil Fertility in Organic Farming Systems. Soil Use Manage 18, 239-247. DOI: 10.1111/j.1475-2743.2002.tb00265.x

Weißmann, F. and Bussemas, R. (2014). Praktische Möglichkeiten Zur Verbesserung der Eiweißversorgung der Monogastrier im Ökologischen Landbau [Possibilities to Improve the Protein Supply of Monogastric Animals in Organic Farming]. In: Praxisbefragung zur Aminosäurelücke und praktische Möglichkeiten zur Verbesserung der Eiweißversorgung der Monogastrier in der Fütterung im Ökologischen Landbau [Survey on the Amino Acid Aap and Possibilities to Improve the Protein Supply of Monogastric Animals in Organic Farming], Thünen Working Paper 23.

Witten, S. and Aulrich, K. (2018). Effect of Variety and Environment on the Amount of Thiamine and Riboflavin in Cereals and Grain Legumes. Anim Feed Sci Tech 238, 39-46. DOI: 10.1016/j.anifeedsci.2018.01.022

Würschum, T., Leiser, W.L., Jähne, F., Bachteler, K., Miersch, M. and Hahn, V. (2018). The Soybean Experiment '1000 Gardens': A Case Study of Citizen Science for Research, Education, and Beyond. Theor Appl Genet. DOI: 10.1007/s00122-018-3134-2 
Zeileis, A. (2004). Econometric Computing with HC and HAC Covariance Matrix Estimators. J Stat Softw 11, 117. DOI: $10.18637 /$ jss.v011.i10

Zollitsch, W. and Baumung, R. (2004). Protein Supply for Organic Poultry: Options and Shortcomings, 2nd SAFO Workshop - Organic livestock farming: potential and limitations of husbandary practice to secure animal health and welfare and food quality, Hovi, M., Sundrum, A., Padel, S., Witzenhausen, Germany, pp. 153-160. 


\section{Chapter II}

\section{Short Communication}

\section{Precaecal digestibility of crude protein and amino acids of a field bean} (Vicia faba L.) and a field pea (Pisum sativum L.) variety for broilers

Ileale Rohprotein- und Aminosäurenverdaulichkeit von je einer ökologisch erzeugten Ackerbohnen- (Vicia faba L.) und Futtererbsensorte (Pisum sativum L.) bei Broilern

\footnotetext{
Stephanie Witten ${ }^{1}$, Michael A. Grashorn ${ }^{2}$, Karen Aulrich ${ }^{1}$

1Johann Heinrich von Thünen-Institute of Organic Farming, Trenthorst 32, 23847

Westerau, Germany

2 Work Group Poultry, Department Population Genomics, Institute of Animal Science, University of Hohenheim, 70593 Stuttgart, Germany
}

Witten, S., Grashorn, M. A., Aulrich, K. 2018: Precaecal digestibility of crude protein and amino acids of a field bean (Vicia faba L.) and a field pea (Pisum sativum L.) variety for broilers. Anim Feed Sci Tech 243, 35-40.

DOI: 10.1016/j.anifeedsci.2018.07.001 


\begin{abstract}
A linear regression approach was used to determine the precaecal digestibility of organic field beans and field peas in young broiler chickens. Diets with field beans of the variety Taifun (283 g crude protein $/ \mathrm{kg} \mathrm{DM}$ ) and field peas of the variety Alvesta (173 g crude protein $/ \mathrm{kg} \mathrm{DM})$ in three inclusion rates $(30,50$, and $70 \%)$ were fed ad libitum to 15- to 21 day-old broiler chickens. Digesta was sampled pen-wise and obtained from the gastrointestinal tract between Meckel's diverticulum and $2 \mathrm{~cm}$ anterior to the ileo-caeco-colonic junction. Despite the high inclusion rates of the test feedstuffs, all diets were accepted by the birds. Feed intake and body mass gain, as well as precaecal crude protein and amino acid digestibility, were higher in chickens fed field bean diets than field pea diets. The precaecal crude protein digestibility of the tested field beans and field peas was 0.84 and 0.81 , respectively. In comparison to lysine, methionine, histidine, and arginine, which were highly digestible at the terminal ileum, tryptophan was less digestible. The precaecal digestibility of crude protein and amino acids of the tested organic field beans and field peas is comparable to literature values for non-organic samples. In conclusion, compared to the literature the test results indicate that systematic differences between organic and nonorganic samples do not exist. Field beans and field peas can serve as a suitable crude protein and amino acids source for broilers.
\end{abstract}

\title{
Keywords
}

ileal, organic farming, poultry, chicken 


\section{Zusammenfassung}

Die praecaecale Verdaulichkeit des Rohproteins und der Aminosäuren von Ackerbohnen und Futtererbsen aus ökologischer Erzeugung bei 21 Tage alten Masthühnern wurde mit Hilfe eines linear regressiven Ansatzes ermittelt. Rationen mit Ackerbohnen der Sorte Taifun (138 - $234 \mathrm{~g}$ Rohprotein/kg T) und Futtererbsen der Sorte Alvesta (108 - $166 \mathrm{~g}$ Rohprotein/kg T) in drei Inklusionsraten (30, 50 und 70\%) wurden zwischen dem 15. und dem 21. Lebenstag ad libitum an Masthühner verfüttert. Trotz der hohen Inklusionsraten der Testfuttermittel war die Akzeptanz der Diäten gut. Am 21. Lebenstag wurde der Chymus aus dem Gastrointestinaltrakt zwischen dem Meckel'schen Divertikel bis $2 \mathrm{~cm}$ vor Einmündung in die Blinddarmsäcke buchtenweise gesammelt. Die Futteraufnahme und die Lebendmassezunahme sowie die praecaecalen Rohprotein- und Aminosäurenverdaulichkeiten waren höher in den Ackerbohnendiäten als in den Futtererbsendiäten. Die praecaecale Verdaulichkeit des Rohproteins betrug 0,84 bei Ackerbohnen und 0,81 bei Futtererbsen. Lysin, Methionin, Histidin und Arginin waren hoch verdaulich, während Cystein und Tryptophan eine geringere praecaecale Verdaulichkeit aufwiesen. Die praecaecale Rohprotein- und Aminosäurenverdaulichkeit der geprüften ökologisch erzeugten Futtermittel war vergleichbar mit Ergebnissen aus Studien mit konventionell erzeugten Proben. Es sind keine systematischen Unterschiede zwischen ökologisch und konventionell erzeugten Futtererbsen und Ackerbohnen hinsichtlich ihrer praecaecalen Rohprotein- und Aminosäurenverdaulichkeit zu beobachten. Ökologisch erzeugte Ackerbohnen und Futtererbsen sind daher eine gute Quelle für Rohprotein und Aminosäuren in der Fütterung von jungen Masthühnern.

\section{Schlüsselworte}

ileal, Ökologischer Landbau, Geflügel, Masthühner 


\section{Introduction}

High amounts of specific essential amino acids (AA) must be available for poultry (Zollitsch et al. 2004). Thus, the precaecal (pc) digestibility of crude protein (CP) and $A A$ has become an important descriptor in feed evaluation for chickens (Ravindran et al. 1999). Since the estimation of endogenous losses is inaccurate (Donkoh \& Moughan 1999), it is more favourable to use approaches without a separate determination of endogenous losses for the evaluation of test feedstuffs. Linear regression approaches fulfil this condition and can be applied when at least three inclusion rates of the test feedstuffs to a basal diet are used (Short et al. 1999, Rodehutscord et al. 2004). Home-grown grain legumes, like field beans and field peas, can supply CP and some of the required AA for poultry. They are also advantageous in view of supporting regional agricultural production. This is important in organic farming, especially, where the sufficient supply with $A A$ is difficult due to legal restrictions. The composition of field beans and field peas varies depending on variety and cultivation environment (Witten et al. 2015). Thus, even their pc digestibility may vary (Kluth et al. 2005a).

This study aimed to determine the pc CP and AA digestibility of a field bean variety and a field pea variety, commonly used in organic farming, in three-week-old broiler chickens.

\section{Materials and Methods}

The animal trial was carried out at the Research Farm for Agriculture "Unterer Lindenhof" of the University of Hohenheim (Stuttgart, Germany) according to the European Directive EU (2010) and approved by local authorities.

As test feedstuffs, the field bean variety Taifun and the field pea variety Alvesta were cultivated in 2015 in Southern Germany (Hohenkammer GmbH, Gut Eichethof) according to current eco-directives (Table II 1). In poultry feeding, varieties that are used are presumed to contain low contents of anti-nutritive factors. Taifun is a field bean variety that is advertised as tannin-free and is available in organic quality. The field pea variety Alvesta, which is high-yielding and used throughout Germany, is white-flowering and, therefore, also low in tannin. 
Table II 1: Analysed amounts of crude nutrients and amino acids (g/kg DM) in the test feedstuffs

\begin{tabular}{lcc}
\hline & Field bean (Vicia faba L.) & Field pea (Pisum sativum L.) \\
\hline Variety & Taifun & Alvesta \\
Crude protein & 283.3 & 173.5 \\
Crude ash & 57.3 & 33.3 \\
Ether extract & 18.6 & 22.6 \\
Crude fibre & 81.3 & 54.5 \\
Lysine & 18.73 & 13.96 \\
Methionine & 2.34 & 2.23 \\
Cystine & 3.87 & 3.49 \\
Threonine & 9.92 & 7.48 \\
Tryptophan & 2.06 & 1.42 \\
Leucine & 20.37 & 12.66 \\
Isoleucine & 10.97 & 7.33 \\
Valine & 12.21 & 8.26 \\
Arginine & 25.82 & 12.41 \\
Histidine & 8.77 & 5.14 \\
Phenylalanine & 12.08 & 8.87 \\
Tyrosine & 8.55 & 5.73 \\
Alanine & 11.56 & 8.06 \\
Glycine & 11.74 & 7.72 \\
Serine & 13.36 & 8.24 \\
Proline & 12.00 & 7.78 \\
Aspartic acid & 30.56 & 20.94 \\
Glutamic acid & 46.39 & 29.27 \\
\hline
\end{tabular}

\section{Animals and housing}

Day-old Hubbard ISA JA 757 mixed-sex broilers, which are commonly used in organic farming, were obtained from Couvoirs de L'Est hatchery in France. The chicks were randomly allocated to cleaned and disinfected pens and housed in groups on wood shavings. The size of the pens was $2.25 \mathrm{~m}^{2}$ permitting a maximum of $5 \mathrm{~kg}$ body mass per $\mathrm{m}^{2}$ and $0.125 \mathrm{~m}^{2}$ floor space per broiler at day 21 . The room was thermostatically controlled with an initial temperature of $32^{\circ} \mathrm{C}$ that was decreased continually to $26^{\circ} \mathrm{C}$ on day 21 . For the first three days, the room was illuminated all day using artificial LED light with a light intensity of more than 20 Lux. From day four, eight hours of darkness and 16 hours of illumination time were applied. The chicks were vaccinated against Newcastle disease via drinking water and controlled twice daily. Feed and water were provided ad libitum. Prior to the trial period, which began on day 14, birds were fed with a starter diet (Table II 2). The diet was formulated to meet nutrient requirements according to GfE (1999).

On day 14, broilers were weighed and, if necessary, exchanged between pens to achieve similar average body mass across all pens. The overall initial body mass was $352.8 \mathrm{~g}$. Groups were then assigned to trial diets. Each trial diet was fed to 17 or 18 birds in six replicate pens for one week from day 15 to day 21 of life. Feed intake was determined. On day 21 , all broilers were killed pen-wise by asphyxiation with carbon dioxide. To ensure gut fill, birds were fed for a minimum of 30 minutes prior to killing. After killing, the carcasses were weighed, and the ileal section of the gut was immediately gathered and examined for 
anomalies. The terminal two-thirds of the ileal section between Meckel's diverticulum and $2 \mathrm{~cm}$ anterior to the ileo-caeco-colonic junction were excised (Kluth et al. 2005b) and cut into short segments. The digesta was flushed out gently with distilled water and pooled penwise.

Table II 2: Ingredients and calculated composition of the starter diet

\begin{tabular}{|c|c|c|c|}
\hline Ingredients & $\mathrm{g} / \mathrm{kg} \mathrm{DM}$ & Composition & g/kg DM \\
\hline Soybeans ${ }^{*}$ & 399.90 & Crude protein & 205.0 \\
\hline Wheat $^{*}$ & 389.90 & Crude fibre & 44.7 \\
\hline Maize* & 109.95 & Ether extract & 86.9 \\
\hline Alfalfa green meal & 50.00 & Methionine & 4.1 \\
\hline Wheat gluten & 5.00 & Lysine & 11.0 \\
\hline Sunflower oil* & 0.50 & Threonine & 7.4 \\
\hline Limestone & 14.00 & Tryptophan & 2.6 \\
\hline Mono-Ca-Phosphate & 20.00 & & \\
\hline Sodium-Bicarbonate & 2.50 & AMEN $_{N}(\mathrm{MJ} / \mathrm{kg} \mathrm{DM})^{3}$ & 12.2 \\
\hline Salt & 2.00 & & \\
\hline Mineral-Premix ${ }^{1}$ & 0.80 & & \\
\hline Vitamin-Premix ${ }^{2}$ & 2.00 & & \\
\hline DL-Methionine & 1.20 & & \\
\hline L-Lysine & 1.10 & & \\
\hline Choline chloride & 1.00 & & \\
\hline Antioxidans & 0.15 & & \\
\hline
\end{tabular}

\section{Trial diets}

All diets were manufactured at the Research Farm for Agriculture "Unterer Lindenhof", pelleted, and stored at ambient temperature. The basal diet contained titanium dioxide as an inert marker, soybeans and wheat gluten as protein feedstuffs, sunflower oil to provide a low-dust feedstuff, minerals, vitamins, and maize starch. It was supplemented with methionine, lysine, and threonine to cover the birds' requirements according to GfE (1999). Each test feedstuff was added at inclusion rates of 30,50 , and $70 \%$ in exchange for maize starch (40, 20, and 0\%; Table II 3).

\section{Chemical Analysis}

The diets and the test feedstuffs were analysed for their dry matter and crude nutrient contents, including starch, according to VDLUFA official methods (VDLUFA 2012). Digesta samples were frozen immediately, freeze-dried, ground to pass a $0.5 \mathrm{~mm}$ sieve, and stored at $-18^{\circ} \mathrm{C}$ until $\mathrm{CP}\left(\mathrm{N}^{*} 6.25\right)$ and $\mathrm{AA}$ analyses were performed. Contents of $\mathrm{AA}$ in test feedstuffs, diets, and in the digesta of birds were analysed according to Directive (EC) No 152/2009 (EC 2009); however, the analysis was modified according to Cohen \& Michaud (1993) regarding derivation, separation, and detection of the hydrolysate amino acids. The inert marker titanium dioxide was determined photometrically (Brandt \& Allam 1987). 
Table II 3: Ingredients and analysed composition (g/kg DM) of the diets with the test feedstuffs bean (Vicia faba L.) and pea (Pisum sativum L.)

\begin{tabular}{|c|c|c|c|c|c|c|}
\hline \multirow{2}{*}{$\begin{array}{l}\text { Ingredients } \\
\text { Bean/Pea }\end{array}$} & \multicolumn{3}{|c|}{ Bean } & \multicolumn{3}{|c|}{ Pea } \\
\hline & 300 & 500 & 700 & 300 & 500 & 700 \\
\hline Maize starch & 400 & 200 & 0 & 400 & 200 & 0 \\
\hline Soybeans* & & 170 & & & 170 & \\
\hline Wheat gluten* & & 64 & & & 64 & \\
\hline Sunflower oil & & 10 & & & 10 & \\
\hline Limestone & & 13 & & & 13 & \\
\hline Mono-Ca-Phosphate & & 23 & & & 23 & \\
\hline Sodium-Bicarbonate & & 10.2 & & & 10.2 & \\
\hline Choline chloride & & 1.0 & & & 1.0 & \\
\hline Salt & & 2.2 & & & 2.2 & \\
\hline Mineral-Premix ${ }^{1}$ & & 0.8 & & & 0.8 & \\
\hline Vitamin-Premix ${ }^{2}$ & & 2.0 & & & 2.0 & \\
\hline DL-Methionine & & 2.8 & & & 2.8 & \\
\hline L-Lysine & & 2.8 & & & 2.8 & \\
\hline L-Threonine & & 1.8 & & & 1.8 & \\
\hline L-Tryptophan & & 0.4 & & & 0.4 & \\
\hline $\mathrm{TiO}_{2}$ & & 5.0 & & & 5.0 & \\
\hline \multicolumn{7}{|l|}{ Composition } \\
\hline ME (MJ) & 14.5 & 13.7 & 13.0 & 14.5 & 13.9 & 13.1 \\
\hline Crude protein & 206.5 & 259.9 & 316.1 & 169.8 & 207.1 & 239.2 \\
\hline Crude fibre & 30.7 & 37.4 & 68.3 & 20.2 & 34.1 & 45.0 \\
\hline Ether extract & 71.9 & 71.7 & 73.6 & 66.4 & 68.7 & 72.3 \\
\hline Methionine & 4.7 & 5.4 & 5.7 & 5.4 & 6.0 & 6.5 \\
\hline Lysine & 13.4 & 17.1 & 20.5 & 11.6 & 15.3 & 17.7 \\
\hline Threonine & 7.8 & 9.9 & 12.8 & 7.5 & 9.4 & 11.7 \\
\hline Tryptophan & 2.3 & 2.7 & 3.2 & 2.0 & 2.5 & 2.7 \\
\hline
\end{tabular}

*organically produced; ${ }^{1}$ Trace elements (mg/kg): Fe 81, Mn 108, Zn 72, Cu 14, J 1,44, Se 0,45 ${ }^{2}$ Vitamin premix (/kg): A 12,600 IU, D3 3,150 IU, E $41 \mathrm{mg}, \mathrm{K} 3 \mathrm{mg}, \mathrm{B}_{1} 3 \mathrm{mg}, \mathrm{B}_{2} 6 \mathrm{mg}, \mathrm{B} 1232 \mu \mathrm{g}$, niacin $53 \mathrm{mg}$, panthotenic acid $13 \mathrm{mg}$, folic acid $1050 \mu \mathrm{g}$, biotine $105 \mu \mathrm{g}$

\section{Calculations and Statistics}

Apparent pc digestibility coefficients ( $p c A D C$ ) of $\mathrm{CP}$ and AA of the diets were calculated pen-wise using the following equation:

$$
p c A D C_{a a}=1-\frac{a a_{d i g} * \mathrm{TiO}_{2} \text { feed }}{\mathrm{TiO}_{2} \operatorname{dig} * a a_{f e e d}},
$$

where $a_{\text {dig }}$ represents the content of the AA or CP in the digesta, aa $a_{\text {feed }}$ represents the content of the AA or CP in the treatment diet, $\mathrm{TiO}_{2 \text { dig }}$ represents the $\mathrm{TiO}_{2}$ content in the digesta, and $\mathrm{TiO}_{2 \text { feed }}$ represents the $\mathrm{TiO}_{2}$ content in the treatment diet.

A one-way anova was used to test the effect of the diet. The standardised pc digestibility coefficients ( $\mathrm{pcSDC}$ ) of $\mathrm{AA}$ and $\mathrm{CP}$ of the test feedstuffs were determined according to Rodehutscord et al. (2004) by linear regression analyses (procedure Im, R Core Team 2017). The intake of the AA or CP was related to the apparently precaecally digestible amount of the test $A A$ or $C P$, (intake* $p c A D C$ ). Since the test feedstuffs are the sole sources of additional protein and $A A$ in the trial diets, the $C P$ and $A A$ content of the basal diet, as well as basal endogenous $\mathrm{CP}$ and $\mathrm{AA}$ losses, are reflected in the estimate of the intercept. Therefore, the estimated slope is unaffected by these factors (Rodehutscord et al. 2004). 
The linearity was tested with scatter plots, and the slope of the regression was taken as a measure of the pcSDC (Rodehutscord et al. 2004, Kluth et al. 2009).

\section{Results}

The bird performance was similar to previous experiments conducted at the farm. Depending on the test feedstuff inclusion rate of 30,50 , and $70 \%$, the broiler chickens increased their initial body mass to 607,623 , and $615 \mathrm{~g}$ with the test diets containing field beans, and to 571,596 , and $609 \mathrm{~g}$ with the test diets containing field peas, respectively. We observed average gain/feed ratios of $0.70,0.76$, and 0.73 for field bean diets and $0.60,0.67$, and 0.69 for field pea diets.

The pcADCs of the diets, which were used for the regression analyses, are shown in Table II 4. They did not differ significantly for AA and CP of diets with different inclusion rates of a test feedstuff.

Table II 4: Coefficients of apparent precaecal digestibility (pcADC) of crude protein and amino acids in trial diets containing organically cultivated field beans (Vicia faba L.) and field peas (Pisum sativum L.) at three inclusion levels (g/kg DM) determined in 21-day-old broiler chickens

\begin{tabular}{|c|c|c|c|c|c|c|c|c|}
\hline \multirow[b]{2}{*}{ Inclusion rate } & \multicolumn{3}{|c|}{ Bean } & \multicolumn{5}{|c|}{ Pea } \\
\hline & 300 & 500 & 700 & & 300 & 500 & 700 & \\
\hline & pcADC & pcADC & pcADC & SE & pcADC & pcADC & pcADC & SE \\
\hline Crude protein & 0.81 & 0.81 & 0.81 & 0.007 & 0.79 & 0.81 & 0.79 & 0.007 \\
\hline Lysine & 0.84 & 0.85 & 0.85 & 0.010 & 0.81 & 0.85 & 0.84 & 0.009 \\
\hline Methionine & 0.86 & 0.87 & 0.87 & 0.010 & 0.89 & 0.89 & 0.88 & 0.007 \\
\hline Cystine & 0.60 & 0.64 & 0.66 & 0.023 & 0.72 & 0.72 & 0.71 & 0.009 \\
\hline Threonine & 0.75 & 0.77 & 0.79 & 0.014 & 0.73 & 0.78 & 0.77 & 0.011 \\
\hline Tryptophan & 0.80 & 0.81 & 0.81 & 0.010 & 0.75 & 0.78 & 0.74 & 0.010 \\
\hline Leucine & 0.83 & 0.83 & 0.83 & 0.009 & 0.78 & 0.81 & 0.79 & 0.008 \\
\hline Isoleucine & 0.80 & 0.81 & 0.82 & 0.010 & 0.76 & 0.80 & 0.77 & 0.009 \\
\hline Valine & 0.78 & 0.80 & 0.82 & 0.010 & 0.73 & 0.78 & 0.75 & 0.010 \\
\hline Arginine & 0.87 & 0.89 & 0.90 & 0.007 & 0.81 & 0.85 & 0.83 & 0.008 \\
\hline Histidine & 0.82 & 0.85 & 0.86 & 0.009 & 0.80 & 0.84 & 0.83 & 0.008 \\
\hline Phenylalanine & 0.84 & 0.84 & 0.84 & 0.009 & 0.82 & 0.83 & 0.82 & 0.007 \\
\hline Tyrosine & 0.80 & 0.80 & 0.83 & 0.009 & 0.78 & 0.80 & 0.78 & 0.008 \\
\hline Alanine & 0.77 & 0.79 & 0.80 & 0.010 & 0.73 & 0.77 & 0.75 & 0.011 \\
\hline Glycine & 0.73 & 0.75 & 0.76 & 0.011 & 0.71 & 0.75 & 0.74 & 0.010 \\
\hline Serine & 0.76 & 0.78 & 0.79 & 0.012 & 0.74 & 0.77 & 0.75 & 0.009 \\
\hline Proline & 0.85 & 0.86 & 0.86 & 0.006 & 0.84 & 0.85 & 0.84 & 0.006 \\
\hline Aspartic acid & 0.76 & 0.80 & 0.80 & 0.008 & 0.71 & 0.75 & 0.73 & 0.009 \\
\hline Glutamic acid & 0.90 & 0.91 & 0.91 & 0.004 & 0.89 & 0.90 & 0.88 & 0.005 \\
\hline Amino acids & 0.83 & 0.83 & 0.85 & 0.008 & 0.80 & 0.83 & 0.81 & 0.007 \\
\hline
\end{tabular}

The relation between ingested and digested amounts was linear for all $A A$ and for $C P$ in field peas and field beans. The pcSDC of CP was 0.84 and 0.81 for the beans and the peas, respectively (Table II 5). 
Table II 5: Coefficients of standardised precaecal digestibility (pcSDC) of crude protein and amino acids in organically cultivated field beans (Vicia faba L.) and field peas (Pisum sativum L.) determined with a linear regression approach in 21-day-old broiler chickens

\begin{tabular}{|c|c|c|c|c|c|c|}
\hline \multicolumn{4}{|c|}{ Bean } & \multicolumn{2}{|l|}{ Pea } & \multirow[b]{2}{*}{$r^{2}$} \\
\hline & pcSDC & SE & $r^{2}$ & pcSID & SE & \\
\hline Crude protein & 0.84 & 0.048 & 0.95 & 0.81 & 0.050 & 0.94 \\
\hline Lysine & 0.90 & 0.050 & 0.95 & 0.91 & 0.042 & 0.97 \\
\hline Methionine & 0.97 & 0.096 & 0.85 & 0.90 & 0.078 & 0.89 \\
\hline Cystine & 0.80 & 0.099 & 0.81 & 0.70 & 0.053 & 0.91 \\
\hline Threonine & 0.88 & 0.058 & 0.93 & 0.87 & 0.050 & 0.95 \\
\hline Tryptophan & 0.81 & 0.081 & 0.86 & 0.78 & 0.071 & 0.88 \\
\hline Leucine & 0.87 & 0.048 & 0.95 & 0.83 & 0.050 & 0.94 \\
\hline Isoleucine & 0.86 & 0.050 & 0.95 & 0.82 & 0.050 & 0.94 \\
\hline Valine & 0.86 & 0.051 & 0.95 & 0.81 & 0.054 & 0.93 \\
\hline Arginine & 0.93 & 0.024 & 0.99 & 0.89 & 0.040 & 0.97 \\
\hline Histidine & 0.93 & 0.034 & 0.98 & 0.90 & 0.039 & 0.97 \\
\hline Phenylalanine & 0.87 & 0.048 & 0.95 & 0.82 & 0.043 & 0.96 \\
\hline Tyrosine & 0.86 & 0.047 & 0.95 & 0.82 & 0.049 & 0.94 \\
\hline Alanine & 0.86 & 0.050 & 0.95 & 0.82 & 0.057 & 0.92 \\
\hline Glycine & 0.83 & 0.055 & 0.93 & 0.80 & 0.051 & 0.94 \\
\hline Serine & 0.86 & 0.060 & 0.92 & 0.79 & 0.054 & 0.93 \\
\hline Proline & 0.89 & 0.041 & 0.97 & 0.86 & 0.045 & 0.96 \\
\hline Aspartic acid & 0.86 & 0.033 & 0.98 & 0.77 & 0.044 & 0.94 \\
\hline Glutamic acid & 0.92 & 0.029 & 0.99 & 0.89 & 0.036 & 0.97 \\
\hline Amino acids & 0.90 & 0.042 & 0.97 & 0.84 & 0.045 & 0.95 \\
\hline
\end{tabular}

Methionine, lysine, histidine, and arginine were well digestible in both test feedstuffs. Tryptophan and cystine were less digestible.

\section{Discussion}

Both test feedstuffs (Table 1) contained low amounts of CP and AA compared to literature values (Partanen et al. 2001, Kluth et al. 2005a). However, the CP and AA concentrations fell within the range of earlier reports of organic field beans and field peas (Kyntäjä et al. 2014, Witten et al. 2015). The methionine content was high in both test feedstuffs but similar to table values (Kyntäjä et al. 2014).

High inclusion rates of grain legumes can be detrimental in poultry. Yet, Masey O'Neill et al. (2012) and Gabriel et al. (2008) formulated diets containing more than $70 \%$ field peas or field beans to determine nutrient digestibility. In our study, high inclusion rates of grain legumes did not lead to health problems or feed refusal. This observation was probably related to the short feeding period of the diets or to low concentrations of anti-nutritive factors (ANF) of the chosen varieties of the test feedstuffs.

The pcSDCs of the CP and AA of field beans and field peas of the present study were either comparable with or higher than compared to values reported in the literature (Simon 2004, Kluth et al. 2005a, Masey O'Neill et al. 2012, Blok \& Dekker 2017). Arginine, glutamic acid, methionine, and lysine of field peas were highly digestible, while cystine and tryptophan were less digestible. Contrary to literature results, histidine of field beans and field peas was 
highly digestible in our study. The findings for the field pea variety Alvesta were similar to the results reported by Kluth et al. (2005a). Low contents of ANF might be responsible for the high pcSDCs of the AA (Brufau et al. 1998, Crépon et al. 2010). However, ANF contents were not analysed.

\section{Conclusions}

We were able to show that the pc digestibility of $C P$ and $A A$ of organic field peas and field beans is not inferior to the one of non-organic ones tested in other studies. Field bean and field pea varieties are valuable sources of $\mathrm{CP}$ and $\mathrm{AA}$ in broiler feeding during the starter period. Moreover, the use of these legumes can reduce the deficit of amino acids in organic broiler feed.

\section{References}

Blok, M.C. and Dekker, R.A. (2017). Table 'Standardized lleal Digestibility of Amino Acids in Feedstuffs for Poultry'. Wageningen Livestock Research. DOI: 10.18174/426333

Brandt, M. and Allam, S. (1987). Analytik von $\mathrm{TiO}_{2}$ im Darminhalt und Kot nach Kjeldahlaufschluß [Analysis of $\mathrm{TiO}_{2}$ in Intestinal-Contents and Dung, Using Kjeldahls Method]. Arch Anim Nutr 37, 453-454.

Brufau, J., Boros, D. and Marquardt, R.R. (1998). Influence of Growing Season, Tannin Content and Autoclave Treatment on the Nutritive Value of near-Isogenic Lines of Faba Beans (Vicia Faba L.) When Fed to Leghorn Chicks. Br Poult Sci 39, 97-105. DOI: 10.1080/00071669889457

Cohen, S.A. and Michaud, D.P. (1993). Synthesis of a Fluorescent Derivatizing Reagent, 6-Aminoquinolyl-NHydroxysuccinimidyl Carbamate, and Its Application for the Analysis of Hydrolysate Amino Acids via High-Performance Liquid Chromatography. Anal Biochem 211, 279-287. DOI: 10.1006/abio.1993.1270

Crépon, K., Marget, P., Peyronnet, C., Carrouée, B., Arese, P. and Duc, G. (2010). Nutritional Value of Faba Bean (Vicia Faba L.) Seeds for Feed and Food. Field Crop Res 115, 329-339. DOI: 10.1016/j.fcr.2009.09.016

Donkoh, A. and Moughan, P.J. (1999). Endogenous lleal Nitrogen and Amino Acid Flows in the Growing Pig Receiving a Protein-Free Diet and Diets Containing Enzymically Hydrolysed Casein or Graded Levels of Meat and Bone Meal. Anim Sci 68, 511-518. DOI: 10.1017/S1357729800050530

EC (2009). Commission Regulation (EC) No 152/2009 of 27 January 2009 Laying Down the Methods of Sampling and Analysis for the Official Control of Feed.

EU (2010). Directive 2010/63/EU of the European Parliament and of the Council of 22 September 2010 on the Protection of Animals Used for Scientific Purposes

Gabriel, I., Lessire, M., Juin, H., Burstin, J., Duc, G., Quillien, L., Thibault, J.N., Leconte, M., Hallouis, J.M., Ganier, P., Mézière, N. and Sève, B. (2008). Variation in Seed Protein Digestion of Different Pea (Pisum Sativum L.) Genotypes by Cecectomized Broiler Chickens: 1. Endogenous Amino Acid Losses, True Digestibility and in Vitro Hydrolysis of Proteins. Livest Sci 113, 251-261. DOI: 10.1016/j.livsci.2007.04.002

GfE (1999). Empfehlungen zur Energie- und Nährstoffversorgung der Legehennen und Masthühner (Broiler) [Recommendations for the Energy and Nutrient Supply for Layers and Broilers]. DLG Verlag, Frankfurt a. M., Germany.

Kluth, H., Fricke, M. and Rodehutscord, M. (2009). Precaecal Amino Acid Digestibility of Different Wheat Cultivars in Broilers. Arch Geflugelk 73, 80-86. ISSN 0003-9098

Kluth, H., Mantei, M., Elwert, C. and Rodehutscord, M. (2005a). Variation in Precaecal Amino Acid and Energy Digestibility between Pea (Pisum Sativum) Cultivars Determined Using a Linear Regression Approach. Br Poult Sci 46, 325-332. DOI: 10.1080/00071660500127415

Kluth, H., Mehlhorn, K. and Rodehutscord, M. (2005b). Studies on the Intestine Section to be Sampled in Broiler Studies on Precaecal Amino Acid Digestibility. Arch Anim Nutr 59, 271-279. DOI: $10.1080 / 17450390500217058$ 
Kyntäjä, A., Partanen, K., Siljander-Rasi, H. and Jalava, T. (2014). Tables of Composition and Nutritional Values of Organically Produced Feed Materials for Pigs and Poultry. . MTT Report 164. ISBN: 978-952-487$571-4$

Masey O'Neill, H.V., Rademacher, M., Mueller-Harvey, I., Stringano, E., Kightley, S. and Wiseman, J. (2012). Standardised Ileal Digestibility of Crude Protein and Amino Acids of UK-Grown Peas and Faba Beans by Broilers. Anim Feed Sci Tech 175, 158-167. DOI: 10.1016/j.anifeedsci.2012.05.004

Partanen, K., Valaja, J., Jalava, T. and Siljander-Rasi, H. (2001). Composition, Ileal Amino Acid Digestibility and Nutritive Value of Organically Grown Legume Seeds and Conventional Rapeseed Cakes for Pigs. Agric Food Sci Finl 10, 309-322. http://urn.fi/URN:NBN:fi-fe201604069115

Ravindran, V., Hew, L.I., Ravindran, G. and Bryden, W.L. (1999). A Comparison of lleal Digesta and Excreta Analysis for the Determination of Amino Acid Digestibility in Food Ingredients for Poultry. Br Poult Sci 40, 266-274. DOI: 10.1080/00071669987692

R Core Team (2017). R: A Language and Environment for Statistical Computing, Version 3.4.0. http://www.Rproject.org/, R Foundation for Statistical Computing, Vienna, Austria.

Rodehutscord, M., Kapocius, M., Timmler, R. and Dieckmann, A. (2004). Linear Regression Approach to Study Amino Acid Digestibility in Broiler Chickens. Br Poult Sci 45, 85-92. DOI: $10.1080 / 00071660410001668905$

Short, F.J., Wiseman, J. and Boorman, K.N. (1999). Application of a Method to Determine lleal Digestibility in Broilers of Amino Acids in Wheat. Anim Feed Sci Tech 79, 195-209. DOI: 10.1016/S0377-8401(99)00022-X

Simon, A. (2004). Praecaecale Aminosäurenverdaulichkeit von Ackerbohnen und Blauen Lupinen bei Broilern [Precaecal Amino Acid Digestibility of Field Beans and Blue Lupins in Broiler Chicken], http://www.ufop.de/Files/3013/3922/7331/Praecaecale_Verdaulichk.Pdf, Last Access 4the of June 2018, UFOP Reports, Humboldt-Universität Berlin, Berlin

VDLUFA (2012). VDLUFA Methodenbuch Band III Die Chemische Untersuchung von Futtermitteln einschl. 1.8. Ergänzungslieferung [VDLUFA Method Book Volume III The Chemical Analyses of Feedstuffs incl. 1st-8th Supplemental Delivery], VDLUFA Verlag, Darmstadt.

Witten, S., Böhm, H. and Aulrich, K. (2015). Effect of Variety and Environment on the Contents of Crude Nutrients, Lysine, Methionine and Cysteine in Organically Produced Field Peas (Pisum Sativum L.) and Field Beans (Vicia Faba L.) Landbauforsch - Appl Agric Forest Res 65, 205-216. DOI: 10.3220/LBF1447765843000

WPSA (1984). The Prediction of Apparent Metabolizable Energy Values for Poultry in Compound Feed. World Poult Sci J 43, 241-253.

Zollitsch, W., Kristensen, T., Kriutzinna, C., MacNaeihde, F. and Younie, D. (2004). Feeding for Health and Welfare: The Challenge of Formulating Well-Balanced Rations in Organic Livestock Production, In: Vaarst, M., Roderick, S., Lund, V. and Lockeretz, W. (Eds.), Animal Health and Welfare in Organic Agriculture, CABI, pp. 329-356. 


\section{Chapter III}

In vitro multi-enzyme approach to determine crude protein and amino acid digestibility of cereals and grain legumes in broiler chicken

In vitro-Multienzymmethode zur Bestimmung der Rohprotein- und Aminosäureverdaulichkeit von Getreide und Körnerleguminosen bei Broilern 


\section{Abstract}

The knowledge of the precaecal digestibility of crude protein and amino acids has gained importance over the last decades. However, since animal welfare is given high priority, animal digestibility experiments are not recommended unless unavoidable. Thus, in vitro approaches to predict the precaecal digestibility of dietary crude protein and amino acids are of interest for feed evaluation. The present study aimed for an adaption of a promising and simple multi-enzyme assay, which uses pepsin and pancreatin to predict the true and standardised precaecal digestibility of crude protein and amino acids in feedstuffs for swine. The adapted in vitro assay should predict the standardised precaecal digestibility of crude protein and amino acids in feedstuffs for broiler chicken. The adaptation of the approach as well as arising complications were described in this chapter.

The conditions of the gastro-intestinal tract of chicken were simulated in three steps, representing the crop, the stomach, and the small intestine. In the adapted in vitro assay, samples are incubated at $41^{\circ} \mathrm{C}$ for 30 minutes in a buffer solution at $\mathrm{pH} 6.0$, for 135 minutes with pepsin at $\mathrm{pH} 2.6$ and for 120 minutes with pancreatin at $\mathrm{pH} 6.4$. The in vitro rate of crude protein disappearance of sixteen different feedstuffs was correlated to their standardised precaecal crude protein and amino acid digestibility in broiler chicken. Regressions between the in vitro rate of crude protein disappearance and the precaecal digestibility of crude protein for 42-day old broiler chicken had high coefficients of determination $\left(R^{2}=0.94\right)$. Furthermore, the precaecal amino acid digestibility could be estimated on the basis of the in vitro rate of crude protein disappearance $\left(R^{2}>0.70\right)$.

The adapted method can be used to predict the precaecal digestibility of crude protein and amino acids in feedstuffs for young broiler chicken. An extension of the calibration with further samples of single and mixed feed with known precaecal digestibility of crude protein and amino acids is recommended.

\section{Keywords}

pepsin, pancreatin, ileal 


\section{Zusammenfassung}

Das Wissen über die praecaecale Verdaulichkeit des Rohproteins und der Aminosäuren von Futtermitteln für monogastrische Nutztiere hat in den letzten Jahrzehnten an Bedeutung in der Geflügelernährung gewonnen. Da dem Tierwohl aber auch eine wachsende Bedeutung zukommt, sollten Versuche mit lebenden Tieren möglichst vermieden werden. Daher sind in vitro Ansätze zur Verdaulichkeitsschätzung von Interesse. Das Ziel dieser Studie war es, eine vielversprechende und einfach umsetzbare in vitro Multienzymmethode zur Bestimmung der Rohprotein- und Aminosäurenverdaulichkeit von Futtermitteln für Schweine so zu adaptieren, dass die praecaecale Verdaulichkeit des Rohproteins und der Aminosäuren für junge Broiler schnell geschätzt werden kann. Das Vorgehen sowie einige aufgetretene Komplikationen während des Adaptationsprozesses werden in diesem Kapitel beschrieben.

Die Bedingungen des Verdauungstraktes von Broilern wurden in drei Schritten, die den Kropf, den Magen und den Dünndarm simulieren, nachgestellt. In der adaptierten Methode werden die Proben bei $41^{\circ} \mathrm{C}$ zunächst 30 Minuten in einem Puffer mit pH 6,0 eingeweicht und danach für 135 Minuten bei pH 2,6 mit Pepsin und für 120 Minuten bei pH 6,4 mit Pankreatin inkubiert. Die in vitro Verschwindensrate des Rohproteins von 16 unterschiedlichen Einzelfuttermitteln war mit ihrer bekannten praecaecalen Verdaulichkeit des Rohproteins und der Aminosäuren für junge Broiler korreliert. Das Bestimmtheitsmaß der Regressionen für die Schätzung der praecaecalen Verdaulichkeit sowohl des Rohproteins $\left(R^{2}=0.94\right)$ als auch der Aminosäuren $\left(R^{2}>0.70\right)$ in 42 Tage alten Broilern aus der in vitro Verschwindensrate des Rohproteins war zufriedenstellend.

Die modifizierte und gekürzte Methode kann daher zur Schätzung der praecaecalen Verdaulichkeit des Rohproteins und der Aminosäuren in Futtermitteln für junge Broiler eingesetzt werden. Eine Erweiterung der Kalibration mit Einzel- und Mischfuttermitteln wird empfohlen.

\section{Schlüsselworte}

Pepsin, Pancreatin, ileal 


\section{Introduction}

Over the last decades, the digestibility of crude protein (CP) and amino acids (AA) has gained importance in feed evaluation for monogastric animals (Dalibard \& Paillard 1995, Ravindran \& Bryden 1999, Perttilä et al. 2002). Thus, results of animal trials were used to derive table values that are applied in ration formulation (Ajinomoto Animal Nutrition Group 2003-2013, Agroscope 2011-2016, Evonik 2016, INRA-CIRAD-AFZ 2018). However, the digestibility of CP and AA can differ between batches of feedstuffs (Masey O'Neill et al. 2012, Zuber et al. 2016a, Zuber et al. 2016b, Zuber \& Rodehutscord 2016). Furthermore, in vivo approaches are diverse and their outcome depends on many factors. Characteristics of the animal, like age, race, or sex, and of trial characteristics, like management (e. g., feeding technique or temperature management) or sampling method and site (ileal digesta or excreta from intact or cecaectomised animals) can affect the trial results (Ravindran et al. 2017). In addition, such trials are time-consuming, costly, and problematic in terms of animal welfare, which is currently of special and growing importance (BMEL 2017). To improve the prediction of the Pc CP and AA digestibility of different batches of feedstuffs without the need for animal trials, various in vitro approaches have been introduced. The most realistic in vitro assays use digestive enzymes to illustrate the processes of the digestive tract. Such assays are not supposed to duplicate the in vivo digestion, which is a very complex process. However, the results of the simplified simulation of the digestion must be replicable and correlated with the in vivo digestibility (Sibbald 1987, Butts et al. 2012) to be valuable.

Boisen \& Fernández $(1991,1995)$ introduced a multi-enzyme method to predict the pc CP and AA digestibility in swine. They used pepsin and pancreatin to simulate the digestion of $\mathrm{CP}$ and $\mathrm{AA}$ in the stomach and in the small intestine, respectively. Their approach is used in scientific projects in its original or in modified forms (Pastuszewska et al. 2004, Jezierny et al. 2010b, Aarhus University 2015, Hoischen-Taubner et al. 2016), because it is simple and realistic. Furthermore, de Coca-Sinova et al. (2008) found the apparent digestibility of soybean meal in broiler chicks to be correlated to the in vitro digestibility, which was determined with the method of Boisen \& Fernández (1995). This makes the approach promising in terms of the prediction of the $\mathrm{pc}$ CP and AA digestibility for broiler chicken. However, the original method is rather time-consuming for a minimum of four days is needed to obtain the results.

The aim of the present study was to adapt the in vitro approach of Boisen \& Fernández (1995) to predict the pc CP and AA digestibility of feedstuffs for broiler chicken and to shorten the analysis time. In this chapter, information on the effects and the complications of the adaptation process are outlined. Furthermore, the adapted method is described. 


\section{Materials and Methods}

\section{Sample set}

For the calibration of the approach, 16 samples (Table III 1) with known pc digestibility of $\mathrm{CP}$ and $\mathrm{AA}$ in broiler chicken were available from prior studies, in which the linear regression approach of Rodehutscord et al. (2004) was used. On the one hand, samples of 14 different organic feedstuffs of a completed project, which dealt with the pc digestibility of CP and AA in 21 - and 42-day old broiler chicken, were available (Ritteser 2015). Furthermore, samples of an organic field pea variety and an organic field bean variety, which were used to determine the pc digestibility of CP and AA in 21-day old broiler chicken (Witten et al. 2018, chapter II), were also available.

Table III 1: Content of crude protein (CP) and amino acids of feedstuffs available for the calibration of the in vitro method (\% DM)

\begin{tabular}{|c|c|c|c|c|c|c|c|c|c|c|c|c|c|c|c|c|}
\hline & BW & $M$ & NB & $\mathrm{NO}$ & $S$ & SB & WR & WT & WW & MKS & FP & FB & LR & $\mathrm{AL}$ & CS & $\mathrm{CSe}$ \\
\hline $\mathrm{CP}$ & 14.6 & 13.3 & 13.8 & 14.0 & 15.1 & 11.6 & 7.9 & 10.9 & 13.8 & 10.8 & 17.4 & 28.3 & 28.4 & 21.3 & 23.6 & 23.4 \\
\hline Lys & 0.81 & 0.21 & 0.49 & 0.57 & 0.41 & 0.46 & 0.32 & 0.37 & 0.34 & 0.26 & 1.40 & 1.87 & 1.56 & 1.09 & 1.08 & 1. \\
\hline Met & 0.23 & 33 & 17 & 0.23 & 0.20 & 0.21 & 0.12 & 6 & 8 & 20 & 0.22 & 0.23 & 0.23 & 0.33 & 0.33 & 0.33 \\
\hline Cys & 0.32 & 0.20 & 0.23 & 0.40 & 0.30 & 0.30 & 0.17 & 0.23 & 0.28 & 0.21 & 0.35 & 0.39 & 0.28 & 0.20 & 0.19 & 0.18 \\
\hline Thr & 0.52 & 0.40 & 0.46 & 0.48 & 0.44 & 0.42 & 0.26 & 0.33 & 0.37 & 0.37 & 0.75 & 0.99 & 0.89 & 0.91 & 0.96 & 0.95 \\
\hline Trp & 0.19 & 0.19 & 0.17 & 0.19 & 0.16 & 0.13 & 0.09 & 0.10 & 0.14 & 0.07 & 0.21 & 0.14 & 0.23 & 0.35 & 0.27 & 0.25 \\
\hline Ile & 0.51 & 0.52 & 0.46 & 0.50 & 0.48 & 0.39 & 0.24 & 0.32 & 0.40 & 0.37 & 0.73 & 1.10 & 0.99 & 0.81 & 0.98 & 0.94 \\
\hline Leu & 0.87 & 1.67 & 0.92 & 1.00 & 0.95 & 0.76 & 0.45 & 0.64 & 0.83 & 1.43 & 1.27 & 2.04 & 1.78 & 1.49 & 1.69 & 1.63 \\
\hline Val & 0.66 & 0.62 & 0.66 & 0.68 & 0.62 & 0.56 & 0.35 & 0.45 & 0.52 & 0.51 & 0.83 & 1.22 & 1.16 & 1.03 & 1.29 & 1.25 \\
\hline Arg & 1.27 & 0.44 & 0.67 & 0.93 & 0.64 & 0.57 & 0.40 & 0.51 & 0.59 & 0.39 & 1.24 & 2.58 & 1.94 & 0.99 & 0.61 & 0.71 \\
\hline His & 0.44 & 0.31 & 0.37 & 0.38 & 0.43 & 0.38 & 0.22 & 0.29 & 0.37 & 0.31 & 0.51 & 0.88 & 0.84 & 0.58 & 0.52 & 0. \\
\hline Phe & 0.62 & 0.75 & 0.71 & 0.70 & 0.66 & 0.55 & 0.31 & 0.44 & 0.58 & 0.55 & 0.89 & 1.21 & 1.19 & 1.00 & 1.04 & 0.92 \\
\hline Tyr & 0.39 & 0.49 & 0.41 & 0.47 & 0.40 & 0.34 & 0.19 & 0.28 & 0.36 & 0.41 & 0.57 & 0.85 & 0.71 & 0.66 & 0.51 & 0.62 \\
\hline Ala & 0.59 & 1.41 & 0.54 & 0.65 & 0.52 & 0.52 & 0.34 & 0.41 & 0.44 & 0.83 & 0.81 & 1.16 & 1.03 & 1.08 & 1.30 & 1.39 \\
\hline Gly & 0.80 & 0.30 & 0.54 & 0.68 & 0.61 & 0.55 & 0.35 & 0.43 & 0.52 & 0.36 & 0.77 & 1.17 & 1.03 & 0.98 & 1.02 & 1.01 \\
\hline Ser & 0.67 & 0.83 & 0.56 & 0.66 & 0.75 & 0.68 & 0.32 & 0.44 & 0.61 & 0.49 & 0.82 & 1.34 & 1.16 & 0.88 & 0.93 & 0.90 \\
\hline Pro & 0.54 & 0.96 & 1.42 & 0.76 & 1.40 & 1.02 & 0.53 & 0.88 & 1.26 & 1.00 & 0.78 & 1.20 & 1.19 & 1.07 & 1.23 & 1.25 \\
\hline Asp & 1.30 & 0.82 & 0.80 & 1.16 & 0.79 & 0.81 & 0.58 & 0.63 & 0.63 & 0.67 & 2.09 & 3.06 & 2.92 & 2.35 & 2.66 & 2.60 \\
\hline Glu & 2.35 & 2.95 & 3.27 & 2.88 & 4.10 & 2.41 & 1.44 & 2.43 & 3.80 & 2.00 & 2.93 & 4.64 & 4.41 & 2.13 & 1.88 & 2.02 \\
\hline
\end{tabular}

\section{Laboratory analyses of crude protein and amino acids}

To calculate the in vitro rate of the $\mathrm{CP}$ and $\mathrm{AA}$ disappearance, the $\mathrm{CP}$ and $\mathrm{AA}$ contents were determined in the original samples and the residuals. The $\mathrm{CP}$ analyses were conducted according to Dumas (vario MAX CUBE, Elementar Analysensysteme $\mathrm{GmbH}$, Hanau, Germany; $\left.N^{*} 6.25\right)$. Contents of $A A$ were analysed according to Directive (EC) No 152/2009 (EC 2009) regarding sample preparation via oxidation and hydrolysis. The subsequent derivatisation and chromatography were performed according to Cohen \& Michaud (1993). See Chapter I for further details on AA analysis. 


\section{In vitro method development}

We based our experiments on a multi-enzyme assay to predict the CP and AA digestibility of feedstuffs for pigs. The assay was introduced by Boisen \& Fernández (1995). In the assay, $1 \mathrm{~g}$ sample material (ground to pass a $1 \mathrm{~mm}$ sieve) is incubated at $39^{\circ} \mathrm{C}$ with pepsin (2000 FIP U/g; Merck No 7190) at pH 2.0 for six hours and afterwards at pH 6.8 with pancreatin (Sigma No P-1750) for 18 hours. The residual of the sample is filtrated and the content of $\mathrm{CP}$ (Kjeldahl $\mathrm{N}^{*} 6.25$ ) and $18 \mathrm{AA}$ is determined. The rate of $\mathrm{CP}$ and $\mathrm{AA}$ disappearance is correlated to the $\mathrm{CP}$ and $\mathrm{AA}$ digestibility in swine. Equations are used to calculate true digestible $C P$ and $A A$, specific endogenous losses of $C P$ and $A A$, and standardised digestible CP and AA.

There were, however, some difficulties in the practical implementation of the original method.

It must be ensured that the incubation temperature is constant over time for all samples. A heating chamber was not available in the experimental setup. Thus, the use of a drying cabinet as an incubator (Jezierny et al. 2010b) was tested. However, it was difficult to insert a stirring plate into the cabinet (kelvitron $\AA$, Heraeus Holding $\mathrm{GmbH}$, Hanau, Germany) without damaging the cable. Furthermore, to add chemicals and enzymes to each sample, the samples must be removed from the drying cabinet. The incubation temperature cannot be held constant while the samples are handled at room temperature. As an alternative, a shaking water bath (1083, GFL Gesellschaft für Labortechnik mbH, Burgwedel, Germany) and a stirring water bath (UNITHERM WAM 15, UniEquip Laborgerätebau- und Vertriebs $\mathrm{GmbH}$, Planegg, Germany) with a circulation thermostat (Corio c, Julabo, Seelbach, Germany) were tested. The samples tended to agglutinate in the vessels when the shaking water bath was used. In this case, they were not soaked with the fluid containing the enzymes, and the results varied widely. The application of the stirring water bath turned out to be suitable to establish a consistent movement of the whole sample in the fluid at a constant incubation temperature. Furthermore, the application of the ANKOM 2000 Automated Fiber Analyzer (ANKOM Technology, Macedon, NY, USA) was tested. In this system, filter bags containing the weighed sample are incubated in a moving strainer, which is placed in a tempered water pot. The handling of the samples and the incubation conditions was simple and accurate in this system.

However, the separation of the residual from the fluid with filters turned out to be difficult as well. The residuals clogged the filters, and, consequently, filtration was stopped. Thus, different filters (filter papers, filter syringes, and glass sample tubes with frits) were tested with and without applying a vacuum. No filter variant was applicable for the filtration of the residuals. In addition, the samples could not be cleanly removed from the filters after drying. This included the filter bags used in the ANKOM system. During the separation of the filter 
and the sample, filter fibres contaminated the sample, which distorted the results of the CP analyses of the residuals. Moreover, centrifugation was tested to separate the residual from the fluid. The separation of the samples from the fluid was satisfactory when centrifuged at 4000 rotations/s (equivalent to $3321^{*} \mathrm{~g}$; Multifuge $1 \mathrm{~S}-\mathrm{R}$ with swing-out rotor Sorvall囚, Heraeus Holding $\mathrm{GmbH}$, Hanau, Germany). The fluid could then be decanted, and the centrifuge tubes containing the samples could be dried in a drying cabinet prior to further analyses. Since their weight was more stable than the weight of polypropylene tubes and the sample could be cleanly removed, glass centrifuge tubes $(45 \mathrm{ml})$ were used. Another advantage of using glass centrifuge tubes was that they could be inserted into the stirring water bath. Thus, there was no need to transfer the sample into another vessel until the CP and $A A$ analyses of the residuals. After those first difficulties were solved, the adaption of the assay got started.

To represent the digestive tract of the chicken, a methodological step was added that embodied the crop. A phosphate buffer $(0.1 \mathrm{M}, \mathrm{pH} 6.0)$ was tested against a citrate buffer $(0.1 \mathrm{M}, \mathrm{pH} 4.5)$ by soaking different samples for 30 minutes. No difference between the buffer solutions in terms of the rate of CP disappearance was found when both were used at body temperature $\left(41^{\circ} \mathrm{C}\right)$. Jezierny et al. (2010b) reported using the incubation temperature of $40^{\circ} \mathrm{C}$. In the present study, increasing the incubation temperature in all steps from $39^{\circ} \mathrm{C}$ to $41^{\circ} \mathrm{C}$ tended to increase the in vitro rate of $\mathrm{CP}$ disappearance.

Further, adaptations were conducted regarding the $\mathrm{pH}$ value and the $\mathrm{DM}$ content of the "digesta", and the duration of the analyses were adapted to meet the conditions of the digestive tract of the broiler chicken.

The literature on the $\mathrm{pH}$ as well as on the retention time of digesta in the gastro-intestinal tract of broiler chicken shows wide variations. The $\mathrm{pH}$ and retention time in chicken are feedstuff- and animal-dependent (Rougière \& Carré 2010, Recoules et al. 2017). Slight changes of the $\mathrm{pH}$ did not affect the outcome of the analysis. Although a shortening of the incubation time did decrease the rate of CP disappearance, it did not have a negative effect on its variability and reliability. However, an addition of fluid, which altered the DM content of the sample, led repeatedly to increased rates of disappearance. Thus, it is of importance to accurately regulate the supply of sample DM and fluid. Consequently, the fluid supply was adapted on the basis of information on the DM content in the digesta in chicken (Bedford et al. 1991, Pettersson et al. 1991).

The enzymes in the digestive tract of broiler chicken are assumed to be roughly the same as in the digestive tract of swine (Recoules et al. 2017), although differences in the pH range and the rate of destruction have been reported between pig and chicken pepsin (CrevieuGabriel et al. 1999). Furthermore, enzyme secretion is depending on the feedstuff (Kokas et al. 1971). However, little is known about avian digestive enzymes, their specifications, 
and their activity. Due to the lack of availability of avian enzymes, porcine pepsin (Merck No 7190) and pancreatin (Sigma No P-1750) were used as in the original method.

Pancreatin can be dispersed in demineralised water or in phosphate buffer with $\mathrm{pH} 6.0$ or 6.8. There were no differences between these fluids regarding solubility or functionality. However, pancreatin was not fully dispersed in either fluid and particles were floating in the solution. When pancreatin was filtrated through a coarse filter (tea filter), particles were removed and the variation between the rate of $\mathrm{CP}$ disappearance of the sample replications was decreased.

Additionally, the effect of the omission of chloramphenicol, the particle size of the sample, and the amount of sample on the outcome of the in vitro analyses was examined.

The omission of chloramphenicol, which was used in the original method to prevent result variations due to bacterial growth, did not affect the in vitro rate of CP disappearance or its variability. It could be used to test feedstuffs with a high natural stock of bacteria. However, it has been reported that the digestive tract including the crop is highly populated by bacteria (Guan et al. 2003, Abbas Hilmi et al. 2007). Bacteria which occur naturally on plant feedstuffs could contribute to the CP digestibility in vivo. Due to their role in digestion, the elimination of bacteria with antibiotics can be detrimental in the in vitro assay.

Löwgren et al. (1989) reported that larger particles need more time to be digested. In the present study, the use of a sample that was ground to pass a $0.5 \mathrm{~mm}$ sieve instead of a $1.0 \mathrm{~mm}$ sieve also decreased the variation of the rate of CP disappearance between the replications of a sample.

Boisen \& Eggum (1991) found larger sample sizes to be more reliable and suggested to use a minimum of $0.5 \mathrm{~g}$. Although Boisen \& Fernández (1995) used $1.0 \mathrm{~g}$ of the test sample, the official method protocol (Aarhus University 2006) instructs the user to use $0.5 \mathrm{~g}$. In the tests of the present study, the low weight of the test sample led to unstable results due to an increased error probability. Thus, tests were conducted to determine the effect of the amount of the test sample on the rate of CP disappearance. Increasing amounts of the weighed sample decreased its CP disappearance rate (Figure III 1). The error possibility and variability of the rate of CP disappearance was also decreased with increasing sample weight. To improve the reliability on the analysis results, the weight of the test sample was increased to $1.5 \mathrm{~g}$. Hoischen-Taubner et al. (2016) did also increase the weight of the test sample in their analyses and simultaneously increased the amount of enzyme. However, since according to Parsons et al. (1997) and Johnston \& Coon (1979) excessive addition of digestive enzymes in in vitro processes can lead to difficulties in assessing differences of the CP degradation rate between samples, the amount of enzyme per sample was not adapted. 


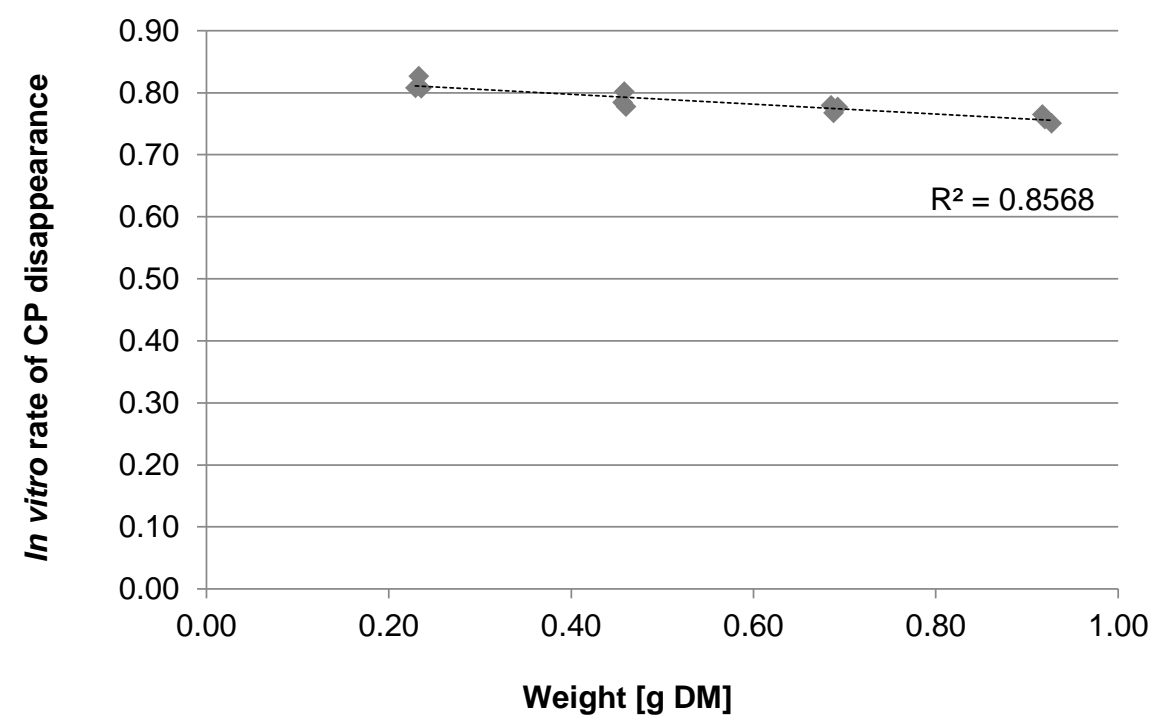

Figure III 1: In vitro rate of crude protein disappearance as a function of sample weight for one field pea sample

\section{Implementation of the final adapted in vitro assay}

Based on a selection of literature reports on retention times in the digestive tract of chicken e. g., (Farner 1942a, Richter et al. 1992, Pang \& Applegate 2007, Denbow 2015, Valentim et al. 2017), the simulation of the crop lasted 30 minutes, the one of the stomach 135 minutes and the one of the small intestine 120 minutes in the adapted assay. An increase of the retention time by 60 minutes in step two or three of the simulated digestive tract did not lead to a smaller variation of the rate of disappearance between repetitions or to an alteration in the sample ranking.

In the adapted method, the incubation temperature was $41.0^{\circ} \mathrm{C}$. The water bath was tempered to $41.3^{\circ} \mathrm{C}$ to ensure a sample temperature of $41.0^{\circ} \mathrm{C}$. To simulate the environment of the crop for 30 minutes ( $20 \% \mathrm{DM}), 7.5 \mathrm{ml}$ phosphate buffer ( $1 \mathrm{M}, \mathrm{pH} 6.0$ ) were added to the sample. Afterwards, $1.5 \mathrm{ml} \mathrm{HCl}(0.2 \mathrm{M})$ containing $0.015 \mathrm{~g}$ pepsin were added to simulate the environment of the stomach with a $\mathrm{pH}$ of 2.6 and a retention time of 120 minutes (16\% DM). Finally, $0.0375 \mathrm{ml} \mathrm{NaOH}(0.6 \mathrm{M})$ plus $1.5 \mathrm{ml}$ phosphate buffer (2M, pH 6.8) containing $0.075 \mathrm{~g}$ pancreatin were added to simulate the environment of the small intestine with a $\mathrm{pH}$ of 6.4 for 135 minutes (14\% DM).

Two stirring water baths with 15 slots each and tubes $(45 \mathrm{ml})$ with $20 \mathrm{~mm}$ agitator sticks were used to analyse the in vitro rate of CP and AA disappearance (Figure III 2). 


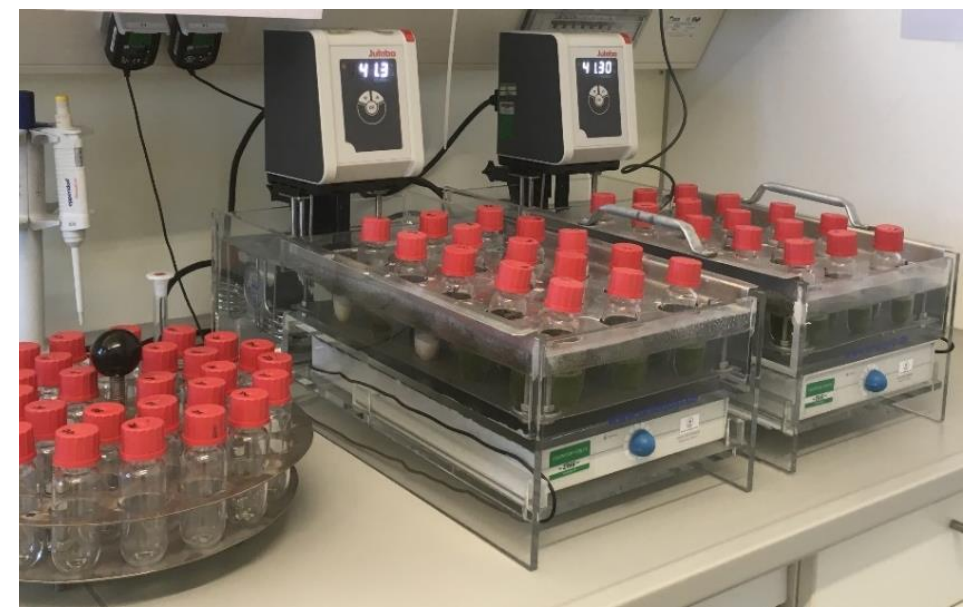

Figure III 2: $\quad$ Stirring water baths with circulation thermostats

Since each transfer of the sample material from one vessel to another increases the probability of sample loss, glass centrifuge tubes $(45 \mathrm{ml})$ were used for the entire analysis. Gloves were worn to handle the tubes in order to avoid electrostatic charging, which would affect the outcome of the weighing and thus the result of the analysis. For the same reason, a de-ioniser was used during weighing. To ensure replicable results, buffer solutions must be disposed and renewed after one week if they have not been used and enzyme solutions must be prepared directly before their application in the analysis.

Wheat was used as a standard in each water bath during each series to evaluate and monitor the quality of the analysis. When the rate of CP disappearance in the standard sample deviated more than 0.01 from the observed results the analysis of the day was repeated as a whole. Blanks did not differ in various tests. Thus, they were not included regularly in the analyses. However, when a new batch of an enzyme was opened, blanks were tested again to ensure the repeatability of the analysis. Since outliers can occur, a minimum of three replicates (four for field beans and five for grassland-derived products) was weighed in for each sample. Another replicate, which was not included in further analyses was used to adjust the $\mathrm{pH}$ value during the analyses.

Following centrifugation $\left(3321^{*} \mathrm{~g}\right.$ in a swing-out rotor as described above), the residuals were gently dried at $40^{\circ} \mathrm{C}$ until weight constancy was reached. To further shorten the procedure, a vacuum oven (Vacutherm, Thermo Fisher Scientific Inc., Waltham, MA, USA) was used to dry the residuals. A drying cabinet can be used alternatively. However, instead of about 12 hours (depending on the sample material) in the vacuum oven, the residuals must be dried for two days in the drying cabinet to reach weight constancy.

Once replicable results ( $N$ disappearance rate \pm 0.01 ) were achieved with the adapted method, we calibrated it using the samples with known pc CP and AA digestibility. A mixed sample consisting of the replicates was used to analyse CP and AA in the residual of the 
test feedstuffs. The in vitro rate of disappearance of $\mathrm{CP}\left(\mathrm{CP}_{d}\right)$, and analogous for $A A\left(A A_{d}\right)$, was calculated using the following equation:

$\mathrm{CP}_{\mathrm{d}}=1-(\mathrm{CP}$ in residual $(\mathrm{g}) / \mathrm{CP}$ in sample $(\mathrm{g}))$

$\underline{\text { Regression analyses to calculate in vitro digestibility coefficients }}$

The calibration of the in vitro method was conducted by regression analyses. The in vitro rate of CP disappearance was related to the in vivo Pc CP and AA digestibility of feedstuffs in 21- and 42-day old broiler chicken (Figure III 3). Furthermore, for each AA, the in vitro rate of its disappearance as well as the in vitro rate of CP disappearance was related to its in vivo pc digestibility.

-Cereals Grain legumes - Fodder legumes - Maize corn silage x not used

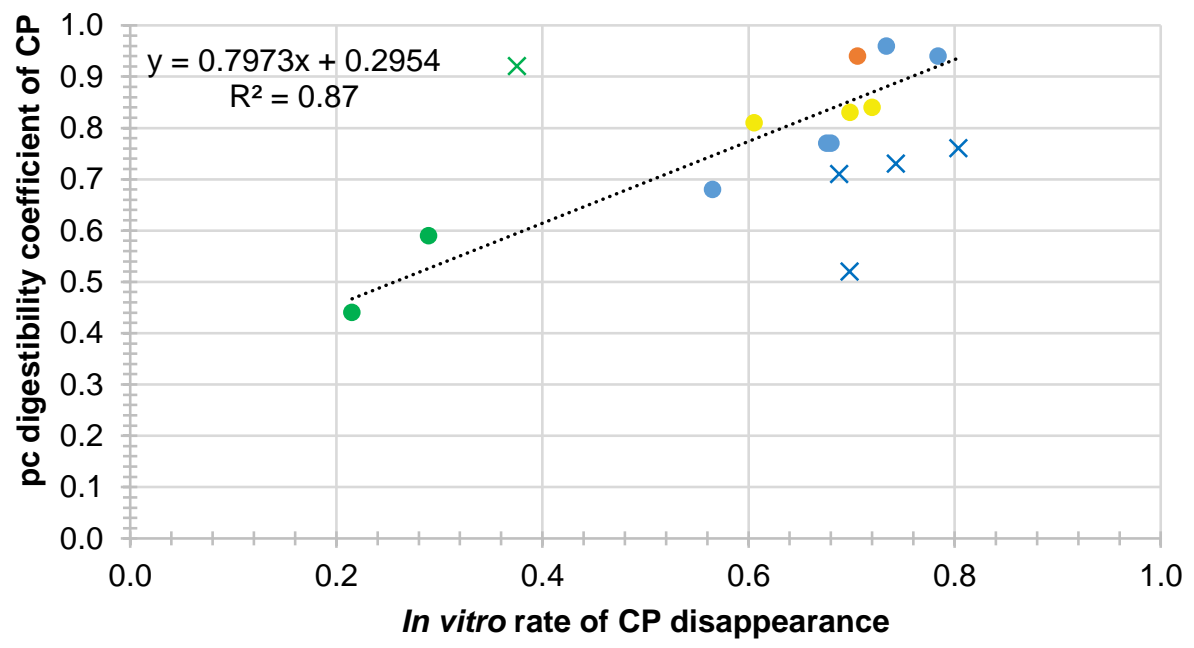

a)

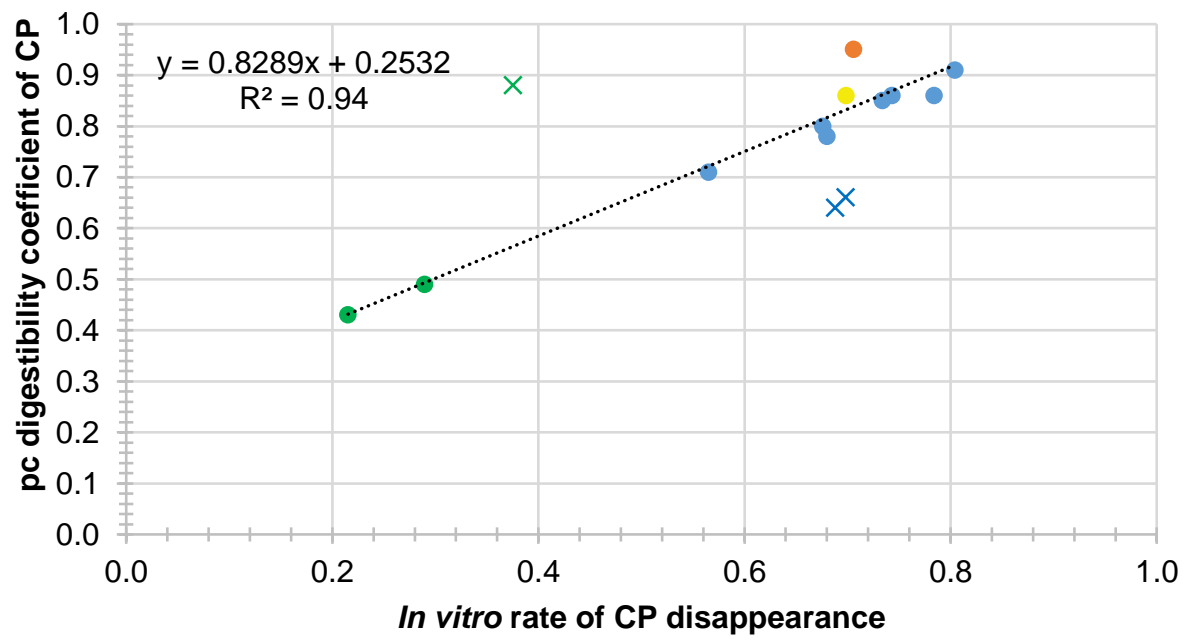

b)

Figure III 3: Relation of the rate of crude protein (CP) disappearance in vitro with the in vivo precaecal (pc) digestibility coefficient of $\mathrm{CP}$ in a) 21-day old and b) 42-day old broiler chicken

The in vitro rate of $\mathrm{CP}$ and $\mathrm{AA}$ disappearance of naked barley could not be determined reliably since the residual could not be separated from the fluid during centrifugation. 
Therefore, naked barley was excluded from the regression analyses. Furthermore, the in vitro rate of $\mathrm{CP}$ disappearance would suggest a lower pc digestibility of alfalfa leaf $\mathrm{CP}$. The $\mathrm{CP}$ of the alfalfa leaf sample was highly digestible in the animal trials, but the feed intake and the daily weight gain were reduced (Ritteser 2015). Thus, a possible explanation for this finding is that decreased contents of $A A$ in the diet led to an increased absorptive capacity and thus to high digestibility coefficients (Corzo et al. 2011). However, for the estimation of the pc digestibility of the CP for 21- and 42-day old broiler chicken (d21 and $\mathrm{d} 42$ ), alfalfa leaves were also removed from the equation. Moreover, the in vitro rate of $\mathrm{CP}$ disappearance of winter rye for $\mathrm{d} 21$ and $\mathrm{d} 42$ and spelt for $\mathrm{d} 21$ did not fit into the equations. The $\mathrm{R}^{2}$ of the regression slope (pc digestibility) was low for winter rye for $\mathrm{d} 21$ and d42-day and for spelt and naked oats for $\mathrm{d} 21$. That might be due to the intake of wood shavings by chickens that were fed diets containing winter rye and spelt (Ritteser 2015). Consequently, these values were also removed. Although higher deviations of the in vitro rates of disappearance were observed for silages (clover and corn), they were included into the equations.

For $\mathrm{d} 21$, the pc digestibility of the CP and AA was known for only three grain legumes and for d42 for only one grain legume. Thus, equations for grain legumes only were not expedient to predict the pc CP and AA digestibility. Nevertheless, ten cereal grains with known pc $\mathrm{CP}$ and $\mathrm{AA}$ digestibility were available, of which five could be used for the prediction of the pc CP and AA digestibility for $\mathrm{d} 21$ and seven for the prediction of the pc $\mathrm{CP}$ and $\mathrm{AA}$ digestibility for $\mathrm{d} 42$. The coefficient of determination was high for the $\mathrm{pc} C P$ digestibility for $d 21\left(y=1.3586 x+0.6593, R^{2}=0.84\right)$ and even higher for the pc CP digestibility for $\mathrm{d} 42\left(\mathrm{y}=0.8009 \mathrm{x}+0.2539, \mathrm{R}^{2}=0.96\right)$.

The same samples were also used in regression analyses to estimate the pc digestibility of the AA. For single AA, the coefficient of determination was higher when the rate of its disappearance was used. However, the rate of $\mathrm{N}$ disappearance was highly correlated with the pc digestibility of all AA. Since the present study aimed for a short time-span of the analysis, it was suitable to use the rate of $\mathrm{N}$ disappearance as the basis for all estimations. However, shifts in the ranking of the pc digestibility of single AA cannot be illustrated sufficiently by this calculation. When only cereals were used to relate the in vitro rate of disappearance to the in vivo pc digestibility of $\mathrm{CP}$ and $\mathrm{AA}$ in $\mathrm{d} 42$, the use of the in vitro rate of AA disappearance improved the coefficient of determination. Thus, further calibration with samples derived from different categories (cereals, grain legumes, forages) can improve the assay. Still, the modified multi-enzyme method is already suitable for the estimation of the standardised pc digestibility of CP and AA in d21 and d42. 


\section{Method protocol}

1. Purpose:

Determination of the in vitro crude protein and amino acid digestibility of feedstuffs for broiler chicken.

2. Principle:

The feed sample is incubated at $41^{\circ} \mathrm{C}$ with a phosphate buffer (30 minutes, $\mathrm{pH} 6.0$ ), pepsin (135 minutes, $\mathrm{pH} 2.6$ ), and pancreatin (120 minutes, $\mathrm{pH}$ 6.4). The sample residual is separated from the fluid using centrifugation. Its dry matter and crude protein content is then determined.

\section{Materials:}

1. Scale with four decimal places

2. Crucibles for dry matter determination

3. Glass centrifuge tubes with screw caps $(45 \mathrm{ml})$

4. Magnetic stirring rods $(20 \mathrm{~mm})$

5. Water bath with a magnetic stirrer and circulation thermostat (Julabo Corio C)

6. Pipette

7. Beakers

8. $\mathrm{pH}$ meter and electrode

9. Magnetic stick

10. Freezer (run at $-18^{\circ} \mathrm{C}$ )

11. Centrifuge (Heraeus Multifuge 1S-R with swing-out rotor Sorvall®)

12. Drying cabinet (Heraeus kelvitron® $\mathrm{t}$ )

13. Vacuum oven (ThermoScientific Vacutherm)

14. Desiccator

15. Mortar

4. Reagents:

All chemicals used are of analytical grade.

1. Phosphate buffer $A$ (PPA), pH $6.0(0.1 \mathrm{M})$ :

$12.1 \mathrm{~g} \mathrm{NaH}_{2} \mathrm{PO}_{4} \cdot \mathrm{H}_{2} \mathrm{O}$ and $1.732 \mathrm{~g} \mathrm{Na}_{2} \mathrm{HPO}_{4}$ are dissolved in ca. $750 \mathrm{ml} \mathrm{H} \mathrm{H}_{2} \mathrm{O}$ demin. using a magnetic stirrer. The $\mathrm{pH}$-value is adjusted with $5 \mathrm{M} \mathrm{NaOH}$ or $5 \mathrm{M} \mathrm{HCl}$. The solution is then filled up to $1000 \mathrm{ml}$ with $\mathrm{H}_{2} \mathrm{O}$ demin.

2. Pepsin solution $(0.01 \mathrm{~g} / \mathrm{ml})$ for 30 places:

$20 \mathrm{ml} \mathrm{HCl}(32 \%)$ are dissolved in $\mathrm{H}_{2} \mathrm{O}$ demin. and filled up to $1000 \mathrm{ml}(\mathrm{HCl}, 0.2 \mathrm{M})$. Immediately before use, $1.05 \mathrm{~g}$ pepsin (Merck No 7190) are dissolved with a magnetic stirrer (200 rotations $/ \mathrm{min}$ ) in $52.5 \mathrm{ml} 0.2 \mathrm{M} \mathrm{HCl}$. 
3. $\mathrm{HCl}$ solution (5 M):

$100 \mathrm{ml} \mathrm{HCl}(32 \%)$ are dissolved in $\mathrm{H}_{2} \mathrm{O}$ demin. and filled up to $200 \mathrm{ml}$ with $\mathrm{H}_{2} \mathrm{O}$ demin.

4. $\mathrm{NaOH}$ solution $(5 \mathrm{M})$ :

$40.0 \mathrm{~g} \mathrm{NaOH}$ are dissolved in $\mathrm{H}_{2} \mathrm{O}$ demin. in a beaker and filled up to $200 \mathrm{ml}$.

5. Pancreatin solution $(0.05 \mathrm{~g} / \mathrm{ml})$ for 30 places:

$7.04 \mathrm{~g} \mathrm{NaH}_{2} \mathrm{PO}_{4} \mathrm{H}_{2} \mathrm{O}$ and $6.96 \mathrm{~g} \mathrm{Na}_{2} \mathrm{HPO}_{4}$ are dissolved in ca. $200 \mathrm{ml} \mathrm{H}_{2} \mathrm{O}$ demin. in a beaker using a magnetic stirrer. The $\mathrm{pH}$-value is adjusted with $5 \mathrm{M} \mathrm{NaOH}$ or $5 \mathrm{M} \mathrm{HCl}$. The solution is then filled up to $250 \mathrm{ml}$ with $\mathrm{H}_{2} \mathrm{O}$ demin. (phosphate buffer $\mathrm{B}$ (PPB), pH 6.8, 0.2 M).

Immediately before use, $2.625 \mathrm{~g}$ pancreatin (Sigma No P-1750) are dissolved with a magnetic stirrer (200 rotations/min) in $52.5 \mathrm{ml}$ PPB for 15 minutes and filtered through a tea filter.

6. $\mathrm{NaOH}$ solution $(0.6 \mathrm{M})$ :

$24.0 \mathrm{~g} \mathrm{NaOH}$ are dissolved in $\mathrm{H}_{2} \mathrm{O}$ demin. in a beaker and filled up to $1000 \mathrm{ml}$.

Procedure:

1. For a double determination of the dry matter ca. $2 \mathrm{~g}$ of the sample (3.1., 3.2.) are weighed. They are dried at $105^{\circ} \mathrm{C}(3.12$.) for at least four hours or until weight constancy, cooled in a desiccator (3.14.), and weighed again (3.1.) afterwards.

2. $1.50 \mathrm{~g}$ of a sample with known crude protein and dry matter contents are weighed (3.1.) in centrifuge tubes (3.3.) for a fourfold determination of the in vitro digestibility. A magnetic stirring rod (3.4.) is inserted into each tube. A standard sample is weighed for each series and each water bath in a fourfold determination.

3. The tubes are inserted into a preheated $\left(41.3^{\circ} \mathrm{C} \rightarrow 41.0^{\circ} \mathrm{C}\right.$ sample temperature) water bath (3.5.) and 7.5 ml PPA (4.1.) are immediately added to each sample using a pipette (3.6.). The samples are then gently stirred (200 rotations $/ \mathrm{min}$ ).

4. The centrifuge tubes are closed with screw caps and incubated at $41^{\circ} \mathrm{C}$ under constant stirring for 30 minutes.

5. Pepsin solution (4.2.) is freshly prepared in a beaker (3.7.).

6. $1.5 \mathrm{ml}$ pepsin solution are added to one selected replicate of each sample. The $\mathrm{pH}$ value of the selected replicates is adjusted to 2.6 with $\mathrm{HCL}$ (4.3.) and $\mathrm{NaOH}$ (4.4.) by using a $\mathrm{pH}$ meter (3.8). $0.0375 \mathrm{ml} \mathrm{H}_{2} \mathrm{O}$ demin. are used to rinse the electrode. The same amount of $\mathrm{HCl}$ or $\mathrm{NaOH}$ that was used in the adjusted sample is now added to the other repetitions of the sample. $0.0375 \mathrm{ml} \mathrm{H}_{2} \mathrm{O}$ demin. and $1.5 \mathrm{ml}$ pepsin solution are also added to the other repetitions of the sample.

7. The centrifuge tubes are closed with screw caps and incubated at $41^{\circ} \mathrm{C}$ under constant stirring for 135 minutes.

8. Pancreatin solution (4.5.) is freshly prepared in a beaker (3.7.). 
9. $0.0375 \mathrm{ml} \mathrm{NaOH}(4.6 ., 0.6 \mathrm{M})$ and $1.5 \mathrm{ml}$ are added to the selected repetition of each sample. The $\mathrm{pH}$ value of those samples is adjusted to 6.4 with $\mathrm{HCL}$ (4.3.) and $\mathrm{NaOH}$ (4.4.) by using a pH meter (3.8.). $\mathrm{H}_{2} \mathrm{O}$ demin. is used to rinse the electrode. The same amount of $\mathrm{HCl}$ or $\mathrm{NaOH}$ that was used in the adjusted sample is now added to the other repetitions of the sample. $0.0375 \mathrm{ml} \mathrm{NaOH}(0.6 \mathrm{M})$ and $1.5 \mathrm{ml}$ pancreatin solution are also added to the other repetitions of the sample.

10. The centrifuge tubes are closed with screw caps and incubated at $41^{\circ} \mathrm{C}$ under constant stirring for 120 minutes.

11. The stirring rods are removed with the magnetic stick (3.9.) and samples are chilled (3.10.) until centrifugation.

12. The samples are centrifuged for 10 minutes at $4^{\circ} \mathrm{C}$ at $3321^{*} \mathrm{~g}(4000$ rotations $/ \mathrm{min}$ in a swing-out rotor; 3.11). The fluid is decanted.

13. The samples are dried in a drying cabinet (3.12.) or vacuum oven (3.13.) at $40^{\circ} \mathrm{C}$ until weight constancy is reached and cooled in a desiccator (3.14.)

14. The centrifuge tubes with the samples are weighed and the rate of DM disappearance $\left(D M_{d}\right)$ is checked for uniformity among replicates. The selected sample for $\mathrm{pH}$ adjustment is disposed if its $\mathrm{DM}_{d}$ deviates.

15. When $D M_{d}$ is satisfactory $(S D<0.01)$, the dried sample residuals are transferred into a suitable vessel and finely ground with a mortar (3.15.) for further analysis.

16. The crude protein content in the residuals is determined.

Calculations:

1. Dry matter (DM):

$\mathrm{DM}=$ weight of the dried sample $(\mathrm{g}) /$ weight of the initial sample $(\mathrm{g})$

2. Rate of $D M$ disappearance $\left(D M_{d}\right)$ :

$\mathrm{DM}_{\mathrm{d}}=1-($ weight of the residual $(\mathrm{g}) /$ weight of the initial sample ( $\mathrm{g}$ in $\mathrm{DM})$ )

3. $\mathrm{CP}$ in weight of the initial sample $\left(\mathrm{CP}_{\mathrm{i}}\right.$ in $\left.\mathrm{g}\right)$ :

$\mathrm{CP}_{\mathrm{i}}=\mathrm{CP}$ concentration $(\%){ }^{*}$ weight of the initial sample ( $\mathrm{g}$ in $\left.\mathrm{DM}\right)$

4. $\mathrm{CP}$ in the undigested residual $\left(\mathrm{CP}_{\mathrm{r}}\right.$ in $\left.\mathrm{g}\right)$ :

$\mathrm{CP}_{\mathrm{r}}=\mathrm{CP}$ concentration (\%) * weight of the residual ( $\mathrm{g}$ in $\left.\mathrm{DM}\right)$

5. Rate of $\mathrm{CP}$ disappearance in vitro $\left(\mathrm{CP}_{\mathrm{d}}\right)$ :

$\mathrm{CP}_{\mathrm{d}}=1-\left(\mathrm{CP}_{\mathrm{r}} / \mathrm{CP}_{\mathrm{i}}\right)$ 
The following equations are used to estimate the pc CP and AA digestibility in broiler chicken at $21(\mathrm{~d} 21)$ and $42(\mathrm{~d} 42)$ days of age $\left(x=\mathrm{CP}_{\mathrm{d}}\right)$ :

$\underline{\mathrm{d} 21}$

CP: $\quad y=0.7973 x+0.2954, \quad R^{2}=0.87$

Lys: $y=1.0824 x+0.1431, \quad R^{2}=0.84$

Met: $y=1.0207 x+0.2020, \quad R^{2}=0.90$

Cys: $y=1.8210 x-0.4764, \quad R^{2}=0.77$

Thr: $y=0.8211 x+0.2911, \quad R^{2}=0.73$

Trp: $y=0.9902 x+0.1487, \quad R^{2}=0.91$

lle: $\quad y=0.5051 x+0.5139, \quad R^{2}=0.63$

Leu: $y=0.5480 x+0.4877, \quad R^{2}=0.54$

Val: $y=0.6237 x+0.4281, \quad R^{2}=0.64$

Arg: $y=1.0815 x+0.1596, \quad R^{2}=0.78$

His: $y=1.0977 x+0.1244, \quad R^{2}=0.76$

Phe: $y=0.8367 x+0.2672, \quad R^{2}=0.72$

Tyr: $y=0.7226 x+0.3718, \quad R^{2}=0.75$

Ala: $y=0.5873 x+0.4439, \quad R^{2}=0.58$

Gly: $y=0.9472 x+0.1802, \quad R^{2}=0.79$

Ser: $y=0.8574 x+0.2582, \quad R^{2}=0.80$

Pro: $y=0.7022 x+0.3721, \quad R^{2}=0.78$

Asp: $y=0.5678 x+0.4719, \quad R^{2}=0.67$

Glu: $y=1.0137 x+0.1789, \quad R^{2}=0.83$ $\underline{\mathrm{d} 42}$

CP: $\quad y=0.8289 x+0.2532, \quad R^{2}=0.94$

Lys: $y=0.9315 x+0.1828, \quad R^{2}=0.92$

Met: $y=0.8886 x+0.2769, \quad R^{2}=0.97$

Cys: $y=1.1389 x-0.0529, \quad R^{2}=0.95$

Thr: $y=0.7672 x+0.2611, \quad R^{2}=0.90$

Trp: $y=1.1215 x+0.0210, \quad R^{2}=0.90$

lle: $\quad y=0.9657 x+0.1322, \quad R^{2}=0.94$

Leu: $y=0.7222 x+0.3485, \quad R^{2}=0.92$

Val: $y=0.8340 x+0.2496, \quad R^{2}=0.89$

Arg: $y=0.9917 x+0.1487, \quad R^{2}=0.91$

His: $y=1.3203 x-0.1245, \quad R^{2}=0.93$

Phe: $y=0.8589 x+0.2319, \quad R^{2}=0.94$

Tyr: $y=0.7974 x+0.2641, \quad R^{2}=0.90$

Ala: $y=0.4962 x+0.4746, \quad R^{2}=0.85$

Gly: $y=0.9577 x+0.1027, \quad R^{2}=0.96$

Ser: $y=0.7791 x+0.2846, \quad R^{2}=0.97$

Pro: $y=0.8654 x+0.2433, \quad R^{2}=0.95$

Asp: $y=0.5072 x+0.4168, \quad R^{2}=0.73$

Glu: $y=0.7334 x+0.3605, \quad R^{2}=0.93$ 


\section{References}

Aarhus University (2006). Metode 83-009-2006: Bestemmelse af Enzymfordojeligt Kvaelstof hos Svin (Efn-Ileal) [Method 83-009-2006: Determination of Enzyme Digestible Nitrogen in Swine]. Danmarks JordsbrugsForskning, Forskningscenter Foulum, Husdyrsundhed, Velfaerd og Ernaering.

Aarhus University (2015). Personal Communication of Prof. Jan Vaerum Norgaard, Department of Animal Science - Animal Nutrition and Physiology, Aarhus University, Denmark.

Abbas Hilmi, H.T., Surakka, A., Apajalahti, J. and Saris, P.E.J. (2007). Identification of the Most Abundant Lactobacillus Species in the Crop of 1- and 5-Week-Old Broiler Chickens. Appl Environ Microb 73, 7867. DOI: 10.1128/AEM.01128-07

Agroscope (2011-2016). Feedbase - the Swiss Feed Database, https://www.feedbase.ch/, University of Zurich, Agroscope. Last access 25th of June 2018.

Ajinomoto Animal Nutrition Group (2003-2013). Ajinomoto Heartland (since April 2018 Ajinomoto Animal Nutrition North America) Amino Acid Database, http://aaa.lysine.com/, Last Acces 25th June 2018.

Bedford, M., Classen, H.L. and Campbell, G.L. (1991). The Effect of Pelleting, Salt, and Pentosanase on the Viscosity of Intestinal Contents and the Performance of Broilers Fed Rye. Poult Sci 70, 1571-1577.

BMEL (2017). Nutztierhaltungsstrategie - Zukunftsfähige Tierhaltung in Deutschland [Livestock Husbandry Strategy], https://www.bmel.de/en/animals/_Texte/Nutztierhaltungsstrategie_En.html.

Boisen, S. and Eggum, B.O. (1991). Critical Evaluation of in Vitro Methods for Estimating Digestibility in SimpleStomach Animals. Nutr Res Reviews 4, 141-162. DOI: 10.1079/NRR19910012

Boisen, S. and Fernández, J.A. (1991). In Vitro Digestibility of Energy and Amino Acids in Pig Feeds, In: Verstegen, M.W.A., Huisman, J. and Den Hartog, L.A. (Eds.), Symposium on Digestive Physiology in Pigs, Pudoc Wageningen EAAP, Wageningen Doorwerth, Netherlands.

Boisen, S. and Fernández, J.A. (1995). Prediction of the Apparent lleal Digestibility of Protein and Amino Acids in Feedstuffs and Feed Mixtures for Pigs by in Vitro Analyses. Anim Feed Sci Tech 51, 29-43. DOI: 10.1016/0377-8401(94)00686-4

Butts, C.A., Monro, J.A. and Moughan, P.J. (2012). In Vitro Determination of Dietary Protein and Amino Acid Digestibility for Humans. Br J Nutr 108, S282-S287. DOI:10.1017/S0007114512002310

Cohen, S.A. and Michaud, D.P. (1993). Synthesis of a Fluorescent Derivatizing Reagent, 6-Aminoquinolyl-NHydroxysuccinimidyl Carbamate, and Its Application for the Analysis of Hydrolysate Amino Acids Via High-Performance Liquid Chromatography. Anal Biochem 211, 279-287. DOI: 10.1006/abio.1993.1270

Corzo, A., Loar II, R., Kidd, M. and Burgess, S. (2011). Dietary Protein Effects on Growth Performance, Carcass Traits and Expression of Selected Jejunal Peptide and Amino Acid Transporters in Broiler Chickens. Braz J Poult Sci 13, 139-146.

Crevieu-Gabriel, I., Gomez, J., Caffin, J.P. and Carre, B. (1999). Comparison of Pig and Chicken Pepsins for Protein Hydrolysis. Reprod Nutr Dev 39, 443-454.

Dalibard, P. and Paillard, E. (1995). Use of the Digestible Amino Acid Concept in Formulating Diets for Poultry. Anim Feed Sci Tech 53, 189-204. DOI: 10.1016/0377-8401(95)02010-W

de Coca-Sinova, A., Valencia, D.G., Jiménez-Moreno, E., Lázaro, R. and Mateos, G.G. (2008). Apparent lleal Digestibility of Energy, Nitrogen, and Amino Acids of Soybean Meals of Different Origin in Broilers. Poult Sci 87, 2613-2623. DOI: 10.3382/ps.2008-00182

Denbow, D.M. (2015). Chapter 14 - Gastrointestinal Anatomy and Physiology A2 - Scanes, Colin G, In: Whittow, G.C. (Ed.), Sturkie's Avian Physiology (Sixth Edition), Academic Press, San Diego, pp. 337-366. 9780-12-747605-6

EC (2009). Commission Regulation (EC) No 152/2009 of 27 January 2009 Laying Down the Methods of Sampling and Analysis for the Official Control of Feed.

Evonik (2016). Evonik Nutrition \& Care Gmbh. Aminodat 5.0, Version 1.03.

Farner, D.S. (1942a). The Effect of Certain Dietary Factors on Gastric Hydrogen Ion Concentration and Acidity in the Domestic Fowl. Poult Sci 22, 295-298. DOI: 10.3382/ps.0220295

Guan, L.L., Hagen, K.E., Tannock, G.W., Korver, D.R., Fasenko, G.M. and Allison, G.E. (2003). Detection and Identification of Lactobacillus Species in Crops of Broilers of Different Ages by Using PCR-Denaturing Gradient Gel Electrophoresis and Amplified Ribosomal DNA Restriction Analysis. Appl Environ Microb 69, 6750-6757. DOI: 10.1128/AEM.69.11.6750-6757.2003

Hoischen-Taubner, S., Sommer, H., Jatsch, C., Hartmann, S., Zahnwetzer, P., Fleck, A. and Sundrum, A. (2016). Schlussbericht: Ermittlung Des Futterwertes Und Der Verdaulichkeit Der Blattmassen Von Luzerne (Medicago Sativa) Und Verschiedenen Kleearten [Report: Investigation into the Nutritional Value and Digestibility of Leaf Matter from Alfalfa (Medicago Sativa) and Various Types of Clover]. Project 11oe055, University of Kassel. 
INRA-CIRAD-AFZ (2018). INRA-CIRAD-AFZ Feed Tables - Composition and Nutritive Values of Feeds for Cattle, Sheep, Goats, Pigs, Poultry, Rabbits, Horses and Salmonids, https://feedtables.com/, Last Access 1st August 2018.

Jezierny, D., Mosenthin, R., Sauer, N. and Eklund, M. (2010b). In Vitro Prediction of Standardised lleal Crude Protein and Amino Acid Digestibilities in Grain Legumes for Growing Pigs. Animal 4, 1987-1996. DOI: $10.1017 / \mathrm{S} 1751731110001114$

Johnston, J. and Coon, C.N. (1979). The Use of Varying Levels of Pepsin for Pepsin Digestion Studies with Animal Proteins. Poult Sci 58, 1271-1273. DOI: 10.3382/ps.0581271

Kokas, E., Kaufman, S.H. and Long, J.C. (1971). Effect of Glucagon on Gastric and Duodenal Secretion in Chickens. Z Vergl Physiol 74, 315-325. DOI: 10.1007/bf00297731

Löwgren, W., Graham, H. and Åman, P. (1989). An in Vitro Method for Studying Digestion in the Pig. Br J Nutr 61, 673-687. DOI:10.1079/BJN19890154

Masey O'Neill, H.V., Rademacher, M., Mueller-Harvey, I., Stringano, E., Kightley, S. and Wiseman, J. (2012). Standardised lleal Digestibility of Crude Protein and Amino Acids of Uk-Grown Peas and Faba Beans by Broilers. Anim Feed Sci Tech 175, 158-167. DOI: 10.1016/j.anifeedsci.2012.05.004

Pang, Y. and Applegate, T.J. (2007). Effects of Dietary Copper Supplementation and Copper Source on Digesta $\mathrm{Ph}$, Calcium, Zinc, and Copper Complex Size in the Gastrointestinal Tract of the Broiler Chicken. Poult Sci 86, 531-537. DOI: 10.1093/ps/86.3.531

Parsons, C.M., Castanon, F. and Han, Y. (1997). Protein and Amino Acid Quality of Meat and Bone Meal. Poult Sci 76, 361-368. DOI: 10.1093/ps/76.2.361

Pastuszewska, B., Vitjazkova, M., Swiech, E. and Taciak, M. (2004). Composition and in Vitro Digestibility of Raw Versus Cooked White- and Colour-Flowered Peas. Nahr.-Food 48, 221-225. DOI: $10.1002 /$ food.200300417

Perttilä, S., Valaja, J., Partanen, K., Jalava, T. and Venäläinen, E. (2002). Apparent lleal Digestibility of Amino Acids in Protein Feedstuffs and Diet Formulation Based on Total vs Digestible Lysine for Poultry. Anim Feed Sci Tech 98, 203-218. DOI: 10.1016/S0377-8401(02)00031-7

Pettersson, D., Graham, H. and Åman, P. (1991). The Nutritive Value for Broiler Chickens of Pelleting and Enzyme Supplementation of a Diet Containing Barley, Wheat and Rye. Anim Feed Sci Tech 33, 1-14. DOI: 10.1016/0377-8401(91)90041-P

Ravindran, V., Adeola, O., Rodehutscord, M., Kluth, H., van der Klis, J.D., van Eerden, E. and Helmbrecht, A. (2017). Determination of lleal Digestibility of Amino Acids in Raw Materials for Broiler Chickens Results of Collaborative Studies and Assay Recommendations. Anim Feed Sci Tech 225, 62-72. DOI: 10.1016/j.anifeedsci.2017.01.006

Ravindran, V. and Bryden, W.L. (1999). Amino Acid Availability in Poultry - in Vitro and in Vivo Measurements. Aust J Agric Res 50, 889-908. DOI: 10.1071/Ar98174

Recoules, E., Sabboh-Jourdan, H., Narcy, A., Lessire, M., Harichaux, G., Labas, V., Duclos, M.J. and RéhaultGodbert, S. (2017). Exploring the in Vivo Digestion of Plant Proteins in Broiler Chickens. Poult Sci 96, 1735-1747. DOI: $10.3382 / p s / p e w 444$

Richter, W., Werner, E., Bähr, H. and van den Weghe, H. (1992). Grundwerte der Tiergesundheit und Haltung [Basic Values of Animal Health and Husbandry]. 3rd Edition. Gustav Fischer Verlag Jena/Stuttgart. ISBN: 3-334-60384-9

Ritteser, C. (2015). Bestimmung präcecaler Verdaulichkeitskoeffizienten für heimische Energie- und Proteinfuttermittel für die Bio-Hühnermast [Estimation of lleal Nutrient Digestibility of Native Energy and Protein Feeding Stuffs for Organic Broilers]. Dissertation, University of Hohenheim.

Rodehutscord, M., Kapocius, M., Timmler, R. and Dieckmann, A. (2004). Linear Regression Approach to Study Amino Acid Digestibility in Broiler Chickens. $\mathrm{Br}$ Poult Sci 45, 85-92. DOI: $10.1080 / 00071660410001668905$

Rougière, N. and Carré, B. (2010). Comparison of Gastrointestinal Transit Times between Chickens from D+ and D- Genetic Lines Selected for Divergent Digestion Efficiency. Animal 4, 1861-1872. DOI:10.1017/S1751731110001266

Sibbald, I.R. (1987). Estimation of Bioavailable Amino-Acids in Feedingstuffs for Poultry and Pigs - a Review with Emphasis on Balance Experiments. Can J Anim Sci 67, 221-301. ISSN: 0800-3984

Valentim, J.K., de Paula, K.L.C., Geraldo, A., Miranda, D.A., Antunes, H.C.F., Lemke, S.S.R., Gonzaga, P.R.d.N. and Chaves, C.A.R. (2017). Usage of Probiotic in Country-Type Broiler's Chicken Diet and Its Effects over the Carcass Yield, Morphology and the Gastrointestinal Ph. Rev bras saúde prod anim 18, 530-541. DOI: 10.1590/s1519-99402017000400004

Witten, S., Grashorn, M.A. and Aulrich, K. (2018). Short Communication: Precaecal Digestibility of Crude Protein and Amino Acids of a Field Bean (Vicia Faba L.) and a Field Pea (Pisum Sativum L.) Variety for Broilers. Anim Feed Sci Tech 243, 35-40. DOI: 10.1016/j.anifeedsci.2018.07.001 
Zuber, T., Maurer, H.P., Möhring, J., Nautscher, N., Siegert, W., Rosenfelder, P. and Rodehutscord, M. (2016a). Variability in Amino Acid Digestibility of Triticale Grain from Diverse Genotypes as Studied in Cecectomized Laying Hens. Poult Sci 95, 2861-2870. DOI: 10.3382/ps/pew174

Zuber, T., Miedaner, T., Rosenfelder, P. and Rodehutscord, M. (2016b). Amino Acid Digestibility of Different Rye Genotypes in Caecectomised Laying Hens. Arch Anim Nutr 70, 470-487. DOI: 10.1080/1745039x.2016.1226035

Zuber, T. and Rodehutscord, M. (2016). Variability in Amino Acid Digestibility of Wheat Grains from Diverse Genotypes Examined in Caecectomised Laying Hens. Europ Poult Sci 80. DOI: 10.1399/eps.2016.156 


\section{Chapter IV}

Effect of variety and environmental conditions on in vitro crude protein and amino acid digestibility of cereals and grain legumes for broiler chicken

Einfluss von Sorte und Umweltbedingungen auf die in vitro Verdaulichkeit des Rohproteins und der Aminosäuren von Getreide und Körnerleguminosen bei Broilern 


\section{Abstract}

Since the small intestine is the main site of amino acid absorption, dietary crude protein and amino acids that are precaecally digested, can possibly be used in the metabolism of chicken. Thus, the knowledge on the precaecal crude protein and amino acid digestibility of feedstuffs is of interest in ration formulation. Due to variations of the nutrient composition of cereals and grain legumes depending on genetic and environmental factors, the digestibility of crude protein and amino acids can also vary. The aim of the study was to use an adapted in vitro multi-enzyme assay to evaluate the variation of the in vitro crude protein and amino acid digestibility of selected cereals and grain legumes as feedstuffs for broiler chicken. Additionally, the effect of variety, harvest year, and harvest site on the in vitro digestibility of crude protein and amino acids was determined.

The in vitro crude protein and amino acid digestibility of samples of organically produced barley (54), wheat (43), rye (50), triticale (48), field peas (37) and field beans (44) was determined using a multi-enzyme assay with pepsin and pancreatin. The effect of variety, year, and/or site/area was evaluated with generalised linear models.

Although variety only affected the in vitro crude protein and amino acid digestibility of winter rye, year and site/area affected the in vitro digestibility of crude protein and amino acids in all cultivars.

The results indicate that wide variations of the precaecal crude protein and amino acid digestibility of cereals and grain legumes occur. Furthermore, they indicate that the precaecal crude protein and amino acid digestibility is more strongly affected by environmental factors than by the variety.

The in vitro crude protein and amino acid digestibility of all cultivars varied widely and was plausible, when compared to table values and literature results. Thus, the assay has the potential to be used in the prediction of the crude protein and amino acid digestibility of cereals and grain legumes. However, the prediction of the in vitro crude protein and amino acid digestibility must be further validated with combined in vivo and in vitro studies.

Keywords

variety, site, year, ileal 


\section{Zusammenfassung}

Der Hauptabsorptionsort von Aminosäuren und Peptiden ist der Dünndarm. Die Nutzung von Rohprotein und Aminosäuren aus dem Futter im Stoffwechsel von Geflügel ist daher nur dann möglich, wenn sie dünndarmverfügbar sind. Aus diesem Grund wird die Kenntnis der praecaecalen Verdaulichkeit des Rohproteins und der Aminosäuren von Futtermitteln in der Rationsgestaltung eingesetzt. Durch die starken Schwankungen der Nährstoffzusammensetzung von Getreide und Körnerleguminosen in Abhängigkeit von genetischen und umweltbedingten Faktoren kann auch die praecaecale Verdaulichkeit des Rohproteins und der Aminosäuren variieren. Das Ziel dieser Untersuchung war daher, die Variation der in vitro Verdaulichkeit des Rohproteins und der Aminosäuren von ausgewählten Getreide- und Körnerleguminosenarten zu bestimmen und den Einfluss von Sorte, Anbauort und Anbaujahr auf die in vitro Verdaulichkeit des Rohproteins und der Aminosäuren zu ermitteln.

Die in vitro Verdaulichkeit des Rohproteins und der Aminosäuren von 54 Gersten-, 43 Weizen-, 50 Roggen-, 48 Triticale-, 37 Futtererbsen- und 44 Ackerbohnenproben aus ökologischer Erzeugung wurden mittels einer Multienzymmethode analysiert. Die Effekte von Sorte, Anbauort und Anbaujahr wurden mit generalisierten linearen Modellen bestimmt. Die Sorte hatte nur bei Winterroggen einen signifikanten Effekt, aber die Umweltbedingungen beeinflussten die in vitro Verdaulichkeit des Rohproteins und der Aminosäuren in allen Kulturen.

Die Ergebnisse weisen darauf hin, dass starke Schwankungen der praecaecalen Verdaulichkeit des Rohproteins und der Aminosäuren bei den ausgewählten Kulturen auftreten. Diese Schwankungen sind bei der zur Verfügung stehenden Stichprobe eher durch das Anbaumanagement und die Umweltbedingungen beeinflussbar als durch genetische Faktoren der Sorte. Die in vitro Methode hat Potential, zur Schätzung der Rohprotein- und Aminosäurenverdaulichkeit von Getreide und Körnerleguminosen eingesetzt zu werden. Die Schätzung der Verdaulichkeit des Rohproteins und der Aminosäuren muss jedoch mit kombinierten in vivo und in vitro Studien weiter validiert werden.

\section{Schlüsselworte}

Sorte, Anbauort, Jahr, praecaecal 


\section{Introduction}

Knowledge of the precaecal (pc) crude protein (CP) and amino acid (AA) digestibility of feedstuffs for monogastric animals is of benefit for an optimised diet formulation (Hoehler et al. 2005, Kluth \& Rodehutscord 2009). Thus, in vivo studies are repeatedly performed to assess the pc CP and AA digestibility. However, animal trials are time-consuming, costly, and problematic with regard to animal welfare. Due to these properties of animal trials, the number of studied feedstuffs is generally low. Mostly, direct comparisons of a small number of feedstuffs are conducted. Since the results are influenced not only by the feedstuffs but also by the chosen method (Kadim \& Moughan 1997, Kadim et al. 2002, Kim et al. 2011), characteristics of the used animals (Huang et al. 2005, Huang et al. 2006, Kim \& Corzo 2012, Ritteser 2015), and environmental conditions during the trials (Wallis \& Balnave 1984, Elbers et al. 1989), comparisons between studies are difficult. Consequently, in vitro techniques designed to estimate the pc digestibility of $\mathrm{CP}$ and $\mathrm{AA}$ are valuable tools in analysing larger sample sets and performing comparisons over time. However, to be useful predictors for the pc CP and AA digestibility, the results obtained with in vitro techniques need to have a high correlation with the actual pc digestibility determined in animal trials (Sibbald 1987, Jezierny et al. 2010). A method with high correlation coefficients is described in Chapter III.

Since the nutrient composition of feedstuffs varies widely (Rodehutscord et al. 2016) and thus affects ration formulation for farm animals, it can be assumed that the pc digestibility of the CP and the AA can also vary. Furthermore, it is known that variety and environmental conditions during cultivation and storage can affect the nutrient composition (see Chapter I) and the nutrient digestibility of feedstuffs (e. g., Rosenfelder et al. 2015, Strang et al. 2016, Zhang et al. 2017).

The aim of the study was to evaluate the application of an adapted in vitro assay and to assess the variation of the in vitro digestibility of $\mathrm{CP}$ and $\mathrm{AA}$ of selected feedstuffs for young broiler chicken. Furthermore, the effect of variety, harvest year and harvest site on the in vitro digestibility of $\mathrm{CP}$ and $\mathrm{AA}$ of selected feedstuffs for young broiler chicken was determined.

\section{Materials and Methods}

\section{Sample set}

In total, 835 samples of organic cereal grains and grain legumes with known contents of CP and $A A$ were available. The samples were cultivated in various variety field trials throughout Germany in the years 2011, 2012, and 2013 (Witten \& Aulrich 2018). Thus, the possible influencing factors known were variety, harvest year, and harvest site. The harvest sites could be aggregated into homogenous climatic areas according to JKI (2018) for further 
statistical analyses. Since the sample set was too extensive to be analysed wholly, it had to be reduced.

The following criteria were applied to select samples in order to evaluate the influence of variety, harvest year, and harvest site:

1. The sample amount should be sufficient to be homogenised and analysed thrice.

2. Factor level manifestations were not taken into consideration when less than three repetitions were available.

3. The repetitions of a factor (variety, harvest year, and harvest site or area; JKI 2018) had to include a minimum of two manifestations of the other two factors.

The reduced sample set contained 54 barley, 50 winter rye, 48 winter triticale, 43 winter wheat, 44 field bean, and 37 field pea samples (Table IV 1).

Table IV 1: Number of samples considered for statistical analyses ( $n$ ), crude protein contents (CP in \% DM, $\mathrm{N}^{*} 6.25$ ), and number of manifestations of the factors (variety, year, and site or area) for each cultivar

\begin{tabular}{|c|c|c|c|c|c|c|}
\hline & $\mathrm{n}$ & $\mathrm{CP}$ & varieties & years & sites & $\operatorname{areas}^{1}$ \\
\hline \multicolumn{7}{|l|}{ Cereals } \\
\hline Winter wheat (Triticum aestivum L.) & 43 & $8.9-15.4$ & 3 & 3 & 8 & \\
\hline Winter rye (Secale cereale L.) & 50 & $6.1-12.4$ & 5 & 3 & 4 & \\
\hline Winter triticale (Triticosecale) & 48 & $7.0-13.0$ & 3 & 3 & 9 & \\
\hline Winter barley (Hordeum vulgare L.) & 15 & $7.4-11.8$ & 3 & 2 & 5 & \\
\hline Spring barley (Hordeum vulgare L.) & 39 & $7.3-11.7$ & 3 & 3 & & 4 \\
\hline \multicolumn{7}{|l|}{ Grain legumes } \\
\hline Spring field pea (Pisum sativum L.) & 37 & $14.8-24.9$ & 5 & 3 & 5 & \\
\hline Spring field bean ( Vicia faba L.) & 44 & $27.3-33.5$ & 4 & 2 & & 3 \\
\hline Total & 276 & & & & & \\
\hline
\end{tabular}

\section{Laboratory analyses}

The in vitro digestibility was analysed according to the method described in Chapter III.

\section{Statistics}

R 3.4.0 (R Core Team 2017) was used for all statistical analyses. The in vitro digestibility of $\mathrm{CP}$ and $\mathrm{AA}$ in different cultivars was compared using generalised linear models $(\mathrm{glm}) . \mathrm{Glm}$ were also implemented to assess influences of the main factors variety, harvest year, and harvest site or area. The aggregated factor area was used for the cultivars spring barley and field bean due to their distribution of harvest sites. The package glmulti (Calcagno 2013) was used to evaluate best-fitted models by Akaike's Information Criterion with correction for sample size (AICc).

Multiple comparisons were calculated using multcomp package (Hothorn et al. 2008) with Ismeans (Lenth 2016) and Bonferroni-Holm adjustment. The package sandwich (Zeileis 2004) was included for a heteroscedasticity and autocorrelation consistent estimation of covariance with robust standard errors (vcovHAC). Due to the inclusion of this feature 
differences between factor manifestations were not found in some cases although the factor was significantly influencing in the glm. Differences between Ismeans were considered significant if $p$-values were lower than 0.05 .

\section{Results}

Wide variations of the in vitro digestibility of all cultivars were observed. The in vitro digestibility of arginine and methionine predicted in winter wheat as feedstuff for 21-day old broiler chicken (Table IV 2) was high and reached $100 \%$ for one sample.

Table IV 2: In vitro crude protein (CP) and amino acid digestibility coefficients* of selected cereals and grain legumes as feedstuffs for 21-day old broiler chicken

\begin{tabular}{|c|c|c|c|c|c|c|c|}
\hline & $\begin{array}{c}\text { Winter wheat } \\
(43) \\
\text { Triticum } \\
\text { aestivum } L .\end{array}$ & $\begin{array}{l}\text { Winter rye } \\
(50) \\
\text { Secale } \\
\text { cereale } L .\end{array}$ & $\begin{array}{c}\text { Winter } \\
\text { triticale (48) } \\
\text { Triticosecale }\end{array}$ & $\begin{array}{c}\text { Winter } \\
\text { barley (15) } \\
\text { Hordeum } \\
\text { vulgare } L .\end{array}$ & $\begin{array}{c}\text { Spring } \\
\text { barley (39) } \\
\text { Hordeum } \\
\text { vulgare } L .\end{array}$ & $\begin{array}{c}\text { Field pea } \\
\text { (37) } \\
\text { Pisum } \\
\text { sativum L. }\end{array}$ & $\begin{array}{l}\text { Field bean } \\
\quad(44) \\
\text { Vicia faba } L .\end{array}$ \\
\hline \multirow[t]{2}{*}{$\mathrm{CP}$} & $0.88 \pm 0.02^{e}$ & $0.83 \pm 0.03^{c}$ & $0.85 \pm 0.02^{d}$ & $0.80 \pm 0.03^{b}$ & $0.78 \pm 0.02^{a}$ & $0.84 \pm 0.04^{\mathrm{cd}}$ & $0.77 \pm 0.03^{a}$ \\
\hline & $0.82-0.92$ & $0.78-0.87$ & $0.82-0.91$ & $0.75-0.85$ & $0.74-0.84$ & $0.76-0.90$ & $0.70-0.87$ \\
\hline \multirow[t]{2}{*}{ Lys } & $0.94 \pm 0.03$ & $0.86 \pm 0.03$ & $0.90 \pm 0.03$ & $0.83 \pm 0.04$ & $0.80 \pm 0.03$ & $0.89 \pm 0.05$ & $0.79 \pm 0.04$ \\
\hline & $0.86-0.99$ & $0.80-0.93$ & $0.85-0.98$ & $0.76-0.90$ & $0.75-0.88$ & $0.77-0.96$ & $0.70-0.92$ \\
\hline \multirow[t]{2}{*}{ Met } & $0.95 \pm 0.03$ & $0.88 \pm 0.03$ & $0.91 \pm 0.02$ & $0.85 \pm 0.04$ & $0.82 \pm 0.03$ & $0.90 \pm 0.05$ & $0.81 \pm 0.03$ \\
\hline & $0.88-1.00$ & $0.82-0.94$ & $0.87-0.99$ & $0.78-0.91$ & $0.77-0.90$ & $0.79-0.97$ & $0.72-0.94$ \\
\hline Cys & $\begin{array}{l}0.86 \pm 0.06 \\
0.73-0.95\end{array}$ & $\begin{array}{l}0.74 \pm 0.06 \\
0.62-0.85\end{array}$ & $\begin{array}{l}0.80 \pm 0.04 \\
0.72-0.92\end{array}$ & $\begin{array}{l}0.68 \pm 0.07 \\
0.56-0.79\end{array}$ & $\begin{array}{l}0.63 \pm 0.05 \\
0.54-0.77\end{array}$ & $\begin{array}{l}0.77 \pm 0.09 \\
0.58-0.90\end{array}$ & $\begin{array}{l}0.62 \pm 0.06 \\
0.45-0.84\end{array}$ \\
\hline Thr & $\begin{array}{l}0.90 \pm 0.03 \\
0.84-0.93\end{array}$ & $\begin{array}{l}0.84 \pm 0.03 \\
0.79-0.89\end{array}$ & $\begin{array}{l}0.86 \pm 0.02 \\
0.83-0.92\end{array}$ & $\begin{array}{l}0.81 \pm 0.03 \\
0.76-0.86\end{array}$ & $\begin{array}{l}0.79 \pm 0.02 \\
0.75-0.85\end{array}$ & $\begin{array}{l}0.85 \pm 0.04 \\
0.77-0.91\end{array}$ & $\begin{array}{l}0.78 \pm 0.03 \\
0.71-0.88\end{array}$ \\
\hline \multirow[t]{2}{*}{ Trp } & $0.88 \pm 0.03$ & $0.81 \pm 0.03$ & $0.84 \pm 0.02$ & $0.78 \pm 0.04$ & $0.75 \pm 0.03$ & $0.83 \pm 0.19$ & $0.75 \pm 0.03$ \\
\hline & $0.81-0.92$ & $0.75-0.87$ & $0.80-0.91$ & $0.71-0.84$ & $0.70-0.83$ & $0.72-0.90$ & $0.65-0.86$ \\
\hline Ile & $\begin{array}{l}0.89 \pm 0.02 \\
0.85-0.91\end{array}$ & $\begin{array}{l}0.85 \pm 0.02 \\
0.82-0.88\end{array}$ & $\begin{array}{l}0.87 \pm 0.01 \\
0.85-0.90\end{array}$ & $\begin{array}{l}0.83 \pm 0.02 \\
0.80-0.86\end{array}$ & $\begin{array}{l}0.82 \pm 0.02 \\
0.80-0.86\end{array}$ & $\begin{array}{l}0.86 \pm 0.02 \\
0.81-0.89\end{array}$ & $\begin{array}{l}0.82 \pm 0.02 \\
0.77-0.88\end{array}$ \\
\hline Leu & $\begin{array}{l}0.89 \pm 0.02 \\
0.85-0.92\end{array}$ & $\begin{array}{l}0.85 \pm 0.02 \\
0.82-0.89\end{array}$ & $\begin{array}{l}0.87 \pm 0.01 \\
0.85-0.91\end{array}$ & $\begin{array}{l}0.84 \pm 0.02 \\
0.80-0.87\end{array}$ & $\begin{array}{l}0.82 \pm 0.02 \\
0.79-0.86\end{array}$ & $\begin{array}{l}0.86 \pm 0.03 \\
0.81-0.90\end{array}$ & $\begin{array}{l}0.82 \pm 0.02 \\
0.77-0.88\end{array}$ \\
\hline Val & $\begin{array}{l}0.89 \pm 0.02 \\
0.84-0.92\end{array}$ & $\begin{array}{l}0.84 \pm 0.02 \\
0.81-0.88\end{array}$ & $\begin{array}{l}0.86 \pm 0.02 \\
0.84-0.91\end{array}$ & $\begin{array}{l}0.82 \pm 0.02 \\
0.78-0.86\end{array}$ & $\begin{array}{l}0.81 \pm 0.02 \\
0.78-0.85\end{array}$ & $\begin{array}{l}0.86 \pm 0.03 \\
0.79-0.90\end{array}$ & $\begin{array}{l}0.80 \pm 0.02 \\
0.75-0.88\end{array}$ \\
\hline Arg & $\begin{array}{l}0.96 \pm 0.03 \\
0.88-1.00\end{array}$ & $\begin{array}{l}0.88 \pm 0.03 \\
0.81-0.94\end{array}$ & $\begin{array}{l}0.91 \pm 0.03 \\
0.87-0.99\end{array}$ & $\begin{array}{l}0.85 \pm 0.04 \\
0.77-0.91\end{array}$ & $\begin{array}{l}0.82 \pm 0.03 \\
0.76-0.90\end{array}$ & $\begin{array}{l}0.90 \pm 0.05 \\
0.79-0.97\end{array}$ & $\begin{array}{l}0.81 \pm 0.04 \\
0.71-0.94\end{array}$ \\
\hline His & $\begin{array}{l}0.93 \pm 0.03 \\
0.85-0.98\end{array}$ & $\begin{array}{l}0.86 \pm 0.03 \\
0.79-0.92\end{array}$ & $\begin{array}{l}0.89 \pm 0.03 \\
0.84-0.97\end{array}$ & $\begin{array}{l}0.82 \pm 0.04 \\
0.75-0.89\end{array}$ & $\begin{array}{l}0.79 \pm 0.03 \\
0.74-0.87\end{array}$ & $\begin{array}{l}0.88 \pm 0.05 \\
0.76-0.95\end{array}$ & $\begin{array}{l}0.78 \pm 0.04 \\
0.68-0.92\end{array}$ \\
\hline Phe & $\begin{array}{l}0.88 \pm 0.03 \\
0.82-0.92\end{array}$ & $0.83 \pm 0.03$ & $\begin{array}{l}0.85 \pm 0.02 \\
0.82-0.91\end{array}$ & $\begin{array}{l}0.80 \pm 0.03 \\
0.74-0.85\end{array}$ & $\begin{array}{l}0.77 \pm 0.03 \\
0.73-0.84\end{array}$ & $\begin{array}{l}0.84 \pm 0.04 \\
0.75-0.90\end{array}$ & $\begin{array}{l}0.77 \pm 0.03 \\
0.69-0.87\end{array}$ \\
\hline \multirow[t]{2}{*}{ Tyr } & $0.90 \pm 0.02$ & $0.85 \pm 0.02$ & $0.88 \pm 0.02$ & $0.83 \pm 0.03$ & $0.81 \pm 0.02$ & $0.87 \pm 0.03$ & $0.81 \pm$ \\
\hline & $0.85-0.94$ & $0.81-0.90$ & $0.85-0.93$ & $0.78-0.87$ & $0.77-0.87$ & $0.79-0.92$ & $0.74-0.89$ \\
\hline Ala & $\begin{array}{l}0.88 \pm 0.02 \\
0.83-0.90\end{array}$ & $\begin{array}{l}0.84 \pm 0.02 \\
0.80-0.87\end{array}$ & $\begin{array}{l}0.85 \pm 0.01 \\
0.83-0.90\end{array}$ & $\begin{array}{l}0.82 \pm 0.02 \\
0.78-0.85\end{array}$ & $\begin{array}{l}0.80 \pm 0.02 \\
0.77-0.85\end{array}$ & $\begin{array}{l}0.85 \pm 0.03 \\
0.78-0.89\end{array}$ & $\begin{array}{l}0.80 \pm 0.02 \\
0.74-0.87\end{array}$ \\
\hline Gly & $\begin{array}{l}0.88 \pm 0.03 \\
0.81-0.92\end{array}$ & $0.81 \pm 0.03$ & $\begin{array}{l}0.84 \pm 0.02 \\
0.80-0.91\end{array}$ & $\begin{array}{l}0.78 \pm 0.04 \\
0.72-0.84\end{array}$ & $\begin{array}{l}0.75 \pm 0.03 \\
0.71-0.83\end{array}$ & $\begin{array}{l}0.83 \pm 0.04 \\
0.73-0.89\end{array}$ & $\begin{array}{l}0.75 \pm 0.03 \\
0.66-0.86\end{array}$ \\
\hline Ser & $\begin{array}{l}0.89 \pm 0.03 \\
0.83-0.93\end{array}$ & $\begin{array}{l}0.83 \pm 0.03 \\
0.78-0.88\end{array}$ & $\begin{array}{l}0.86 \pm 0.02 \\
0.82-0.92\end{array}$ & $\begin{array}{l}0.80 \pm 0.03 \\
0.75-0.85\end{array}$ & $\begin{array}{l}0.78 \pm 0.03 \\
0.74-0.84\end{array}$ & $\begin{array}{l}0.85 \pm 0.04 \\
0.76-0.90\end{array}$ & $\begin{array}{l}0.77 \pm 0.03 \\
0.70-0.88\end{array}$ \\
\hline Pro & $\begin{array}{l}0.89 \pm 0.02 \\
0.84-0.92\end{array}$ & $\begin{array}{l}0.84 \pm 0.02 \\
0.80-0.88\end{array}$ & $\begin{array}{l}0.86 \pm 0.02 \\
0.83-0.91\end{array}$ & $\begin{array}{l}0.82 \pm 0.03 \\
0.77-0.86\end{array}$ & $\begin{array}{l}0.80 \pm 0.02 \\
0.76-0.85\end{array}$ & $\begin{array}{l}0.86 \pm 0.03 \\
0.78-0.90\end{array}$ & $\begin{array}{l}0.79 \pm 0.02 \\
0.73-0.88\end{array}$ \\
\hline Asp & $\begin{array}{l}0.89 \pm 0.02 \\
0.85-0.92\end{array}$ & $0.85 \pm 0.02$ & $0.87 \pm 0.01$ & $\begin{array}{l}0.83 \pm 0.02 \\
0.79-0.87\end{array}$ & $\begin{array}{l}0.82 \pm 0.02 \\
0.79-0.86\end{array}$ & $0.86 \pm 0.03$ & $\begin{array}{l}0.81 \pm 0.02 \\
0.76-0.88\end{array}$ \\
\hline Glu & $\begin{array}{l}0.92 \pm 0.03 \\
0.85-0.97\end{array}$ & $\begin{array}{l}0.85 \pm 0.03 \\
0.79-0.91\end{array}$ & $\begin{array}{l}0.89 \pm 0.02 \\
0.84-0.96\end{array}$ & $\begin{array}{l}0.82 \pm 0.04 \\
0.75-0.88\end{array}$ & $\begin{array}{l}0.79 \pm 0.03 \\
0.74-0.87\end{array}$ & $\begin{array}{l}0.83 \pm 0.04 \\
0.76-0.89\end{array}$ & $\begin{array}{l}0.79 \pm 0.03 \\
0.70-0.91\end{array}$ \\
\hline
\end{tabular}

*means and standard deviations as well as ranges; superscripts mark significant differences between columns $(p<0.05)$ and are analogous for CP and all amino acids

Since the equations to estimate the in vitro AA digestibility were based on the rate of in vitro CP disappearance, variations of all AA digestibility coefficients were analogous to the ones 
of the in vitro CP digestibility coefficient. The in vitro digestibility equations, which were used to predict the pc digestibility of CP and AA in 21-day old broiler chicken, yielded higher digestibility coefficients than the equations for 42-day old broiler chicken. Thus, the coefficients of the in vitro CP and AA digestibility in all cultivars were lower for 42-day old broiler chicken than the ones for 21-day old broiler chicken (Table IV 3 ).

Table IV 3: In vitro crude protein (CP) and amino acid digestibility coefficients* of selected cereals and grain legumes as feedstuffs for 42-day old broiler chicken

\begin{tabular}{|c|c|c|c|c|c|c|c|}
\hline & $\begin{array}{l}\text { Winter wheat } \\
\text { (43) } \\
\text { Triticum } \\
\text { aestivum L. }\end{array}$ & $\begin{array}{l}\text { Winter } \\
\text { rye }(50) \\
\text { Secale } \\
\text { cereale } L .\end{array}$ & $\begin{array}{l}\text { Winter } \\
\text { triticale (48) } \\
\text { Triticosecale }\end{array}$ & $\begin{array}{l}\text { Winter } \\
\text { barley (15) } \\
\text { Hordeum } \\
\text { vulgare } L .\end{array}$ & $\begin{array}{l}\text { Spring } \\
\text { barley (39) } \\
\text { Hordeum } \\
\text { vulgare } L \text {. }\end{array}$ & $\begin{array}{l}\text { Field } \\
\text { pea (37) } \\
\text { Pisum } \\
\text { sativum L. }\end{array}$ & $\begin{array}{l}\text { Field } \\
\text { bean (44) } \\
\text { Vicia faba } L .\end{array}$ \\
\hline \multirow[t]{2}{*}{$\mathrm{CP}$} & $0.86 \pm 0.03^{e}$ & $0.81 \pm 0.03^{c}$ & $0.83 \pm 0.02^{d}$ & $0.78 \pm 0.03^{b}$ & $0.76 \pm 0.02^{a}$ & $0.82 \pm 0.04^{\mathrm{cd}}$ & $0.75 \pm 0.03^{a}$ \\
\hline & $0.80-0.90$ & $0.75-0.85$ & $0.80-0.89$ & $0.72-0.83$ & $0.71-0.82$ & $0.73-0.88$ & 0.68 \\
\hline \multirow[t]{2}{*}{ Lys } & $0.87 \pm 0.03$ & $0.80 \pm 0.03$ & $0.83 \pm$ & $0.77 \pm 0.04$ & $0.75 \pm 0.03$ & $0.82 \pm 0.04$ & $=0.03$ \\
\hline & $0.80-$ & $0.75-0.86$ & $0.79-$ & $0.71-0$ & $0.70-0.82$ & $0.72-0.88$ & $0.66-0.85$ \\
\hline \multirow[t]{2}{*}{ Met } & $0.93 \pm$ & $0.87 \pm$ & $0.90 \pm$ & $0.84 \pm 0.03$ & $0.82 \pm 0.03$ & $0.89 \pm 0.04$ & $0.81 \pm 0.03$ \\
\hline & $0.87-$ & 0.81 & 0.86 & $0.78-0.89$ & $0.77-0.88$ & $0.79-0.95$ & 0.92 \\
\hline \multirow[t]{2}{*}{ Cys } & $0.79 \pm 0$ & $0.71 \pm 0.04$ & 0.74 & $0.67 \pm$ & $0.64 \pm 0.03$ & $0.73 \pm 0.05$ & $0.63 \pm 0.04$ \\
\hline & $0.70-0.84$ & $0.64-0.77$ & $0.69-$ & $0.59-0.74$ & $0.58-0.72$ & $0.61-0.81$ & $0.53-0.77$ \\
\hline \multirow[t]{2}{*}{ Thr } & $0.83 \pm 0.02$ & $0.77 \pm 0.02$ & 02 & $0.75 \pm$ & $0.73 \pm 0.02$ & $0.79 \pm 0.04$ & $=0.03$ \\
\hline & 0.77 & $0.72-c$ & 0.7 & 0. & $9-0.79$ & $0.71-0$ & 0.81 \\
\hline \multirow[t]{2}{*}{ Trp } & 0.85 & $0.77 \pm$ & 3 & 0 . & \pm 0.03 & $0.79 \pm$ & 04 \\
\hline & 0.7 & 0.7 & & & -0 & $0.67-$ & \\
\hline \multirow[t]{2}{*}{ Ile } & 0.84 & $0.78 \pm$ & & 0 & $2 \pm 0.03$ & $0.79 \pm$ & $0.11-0$ \\
\hline & $0.77-0.89$ & $0.72-0$ & 38 & - & $7-0.79$ & $0.69-0$ & $0.62-0.83$ \\
\hline \multirow[t]{2}{*}{ Leu } & $0.88 \pm 0$ & $0.83 \pm 0$ & & \pm & $9 \pm 0.02$ & $0.84 \pm$ & \pm 0.02 \\
\hline & 0.8 & $0.79-$ & & 0 & $5-0.84$ & $0.77-0.89$ & 0.87 \\
\hline \multirow[t]{2}{*}{ Val } & 0.86 & $0.81 \pm$ & & 0 . & \pm 0.02 & $0.82 \pm 0$ & 03 \\
\hline & 0.8 & 0.7 & & 3 & -0.82 & $0.73-1$ & \\
\hline \multirow[t]{2}{*}{ Arg } & 0.88 & $0.81 \pm$ & & $0.78 \pm$ & $0.75 \pm 0.03$ & $0.83 \pm 0.05$ & $=0.03$ \\
\hline & $0.81-0.92$ & $0.75-0$ & 0. & 0.7 & $0.70-0.83$ & $0.72-0.90$ & 36 \\
\hline \multirow[t]{2}{*}{ His } & $0.85 \pm 0.04$ & $0.76 \pm 0$ & 03 & 5 & $0.68 \pm 0.04$ & $0.78 \pm 0.06$ & 04 \\
\hline & 0.75 & 0.6 & & & -0.78 & $0.64-0.87$ & 3 \\
\hline \multirow[t]{2}{*}{ Phe } & $0.86 \pm 0.03$ & $0.80 \pm 0$ & 02 & $3 \pm$ & $5 \pm 0.03$ & $0.82 \pm$ & 0.7 \\
\hline & 0.80 & $0.75-$ & & 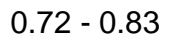 & $1-0.82$ & $073-8$ & 35 \\
\hline \multirow[t]{2}{*}{ Tyr } & $0.85 \pm 0.02$ & $0.80 \pm 0$ & & $0.77 \pm$ & $5 \pm 0.02$ & $0.81 \pm$ & $=0.03$ \\
\hline & $0.79-0.89$ & $0.75-0$ & 38 & $0.72-0$ & $0.71-0.81$ & $0.73-0$ & 4 \\
\hline \multirow[t]{2}{*}{ Ala } & $0.81 \pm 0.01$ & $0.78 \pm 0$ & 01 & $0.77 \pm 0$ & $0.75 \pm 0.01$ & $0.79 \pm$ & 02 \\
\hline & $0.78-0.84$ & $0.75-0.81$ & & $0.74-0.80$ & $0.73-0.79$ & $0.74-0.82$ & -0.81 \\
\hline \multirow[t]{2}{*}{ Gly } & $0.81 \pm 0.03$ & $0.74 \pm 0.03$ & $0.77 \pm 0.02$ & $0.71 \pm 0.04$ & $0.68 \pm 0.03$ & $0.76 \pm 0.05$ & \pm 0.03 \\
\hline & $0.74-$ & $0.68-($ & & $0.65-c$ & $0.64-0.76$ & $0.66-0.82$ & 79 \\
\hline \multirow[t]{2}{*}{ Ser } & $0.86 \pm 0.02$ & $0.80 \pm 0.02$ & $0.83 \pm 0.02$ & $0.78 \pm 0.03$ & $0.76 \pm 0.02$ & $0.82 \pm 0.04$ & $0.75 \pm 0.03$ \\
\hline & $0.80-0.8$ & $0.76-0$. & & $0.73-0$ & $0.72-0.82$ & $0.74-0.87$ & \\
\hline \multirow[t]{2}{*}{ Pro } & $0.88 \pm 0.03$ & $0.82 \pm 0.03$ & $0.85 \pm$ & $0.79 \pm 0.03$ & $0.77 \pm 0.03$ & $0.84 \pm 0.04$ & $0.76 \pm 0.03$ \\
\hline & $0.82-0.92$ & $0.77-0.87$ & $0.81-0.91$ & $0.73-0.84$ & $0.73-0.83$ & $0.74-0.90$ & $0.68-0.87$ \\
\hline \multirow[t]{2}{*}{ Asp } & $0.79 \pm 0.02$ & $0.75 \pm 0.02$ & $0.77 \pm 0.01$ & $0.74 \pm 0.02$ & $0.72 \pm 0.02$ & $0.76 \pm 0.02$ & $0.72 \pm 0.02$ \\
\hline & $0.75-0.81$ & $0.72-0.79$ & & $0.70-0.77$ & $0.70-0.76$ & $0.71-0.80$ & $0.68-0.78$ \\
\hline \multirow[t]{2}{*}{ Glu } & $0.90 \pm 0.02$ & $0.85 \pm 0.02$ & $0.87 \pm 0.02$ & $0.83 \pm 0.03$ & $0.81 \pm 0.02$ & $0.86 \pm 0.03$ & $0.80 \pm 0.02$ \\
\hline & $0.85-0.93$ & $0.80-0.89$ & $0.84-0.92$ & $0.78-0.87$ & $0.77-0.86$ & $0.79-0.91$ & $0.73-0.89$ \\
\hline
\end{tabular}

${ }^{*}$ means and standard deviations as well as ranges; superscripts mark significant differences between columns $(p<0.05)$ and are analogous for CP and all amino acids

The differences between the cultivars were analogous to the ones described for 21-day old broiler chicken. In winter wheat and similarly in winter triticale, CP and AA were highly digestible. Winter rye and field peas had also a high in vitro CP and AA digestibility. However, it varied somewhat more and its minimum was lower. The in vitro digestibility of 
$\mathrm{CP}$ and $\mathrm{AA}$ was the lowest in spring barley and field beans (statistically significant, $p<0.05$ ). Furthermore, the widest variation was observed for field beans $(0.17)$.

The variety had a significant effect on the in vitro CP and AA digestibility exclusively in winter rye. However, the factor harvest site or area affected the in vitro digestibility of $C P$ and $A A$ of all cultivars. The factor year was included in the glm for winter wheat, winter rye, spring barley, and field pea. However, the effect of the factor year was not always significant in these cultivars (Table IV 4). The effects were the same for the in vitro digestibility of each AA. They differed only slightly by their $p$ - and F-values.

Table IV 4: F- and p-values (in italics) of main factors in models describing varietal and environmental impact on the in vitro crude protein digestibility of selected cultivars for 21- and 42-day old broiler chicken

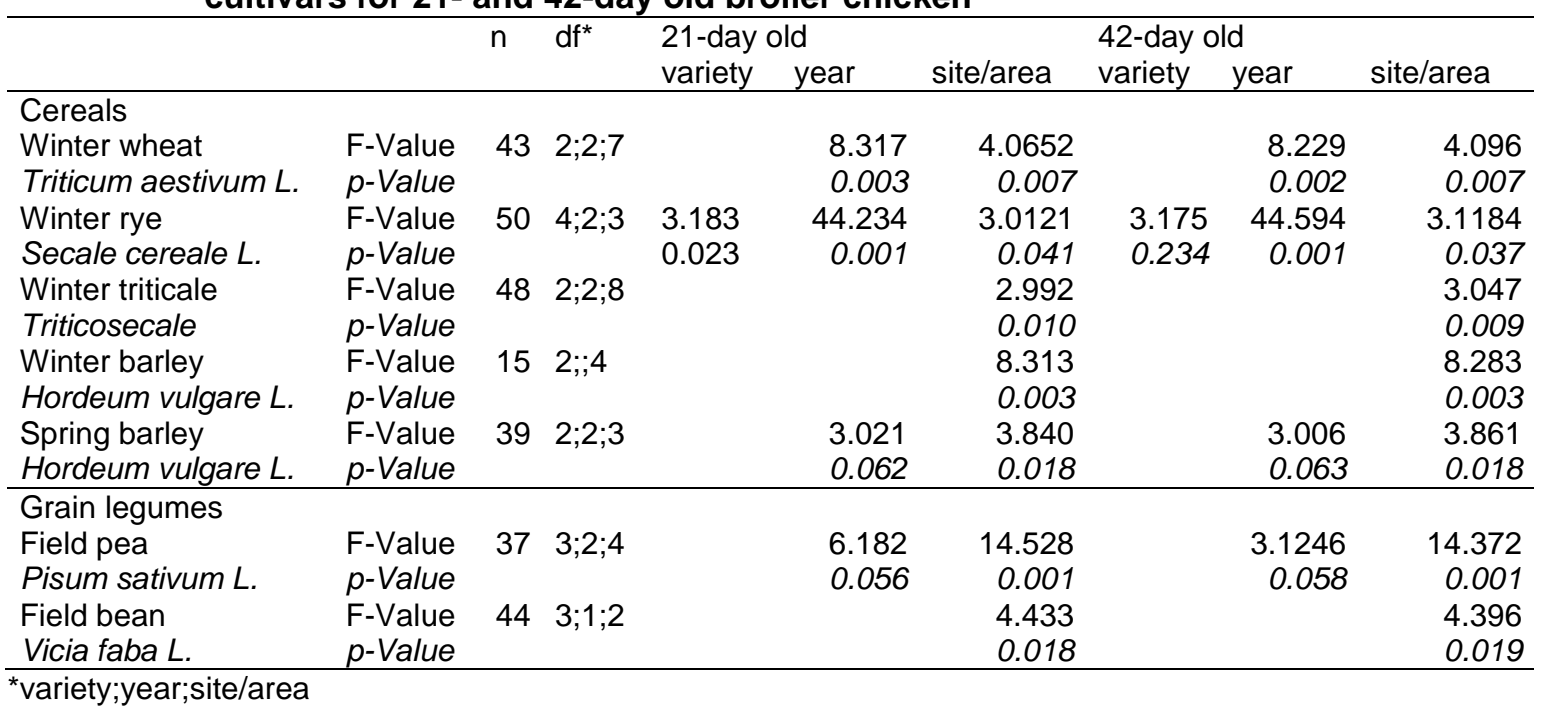

A statistically significant effect of the harvest site or area, respectively, on the in vitro digestibility coefficients of CP was found for all cultivars (Figure IV 1). Although differences of the in vitro $\mathrm{CP}$ and $\mathrm{AA}$ digestibility were observed between the harvest years (winter wheat) and the harvest site or area (all cultivars), there was no consistent pattern between the cultivars (Appendix Table A IV 1).

The in vitro CP digestibility coefficient of spring barley and field beans was statistically significantly different between the areas by up to 0.03 . A large variability of the in vitro digestibility coefficient of CP of up to 0.09 between two sites was determined in field peas. In winter wheat, winter triticale, and winter barley, the in vitro CP digestibility coefficient differed by $0.05-0.07$ between two sites, which were both located in the same area. The differences of the in vitro digestibility of all $A A$ between factor manifestations were analogous to the ones of the in vitro CP digestibility. 


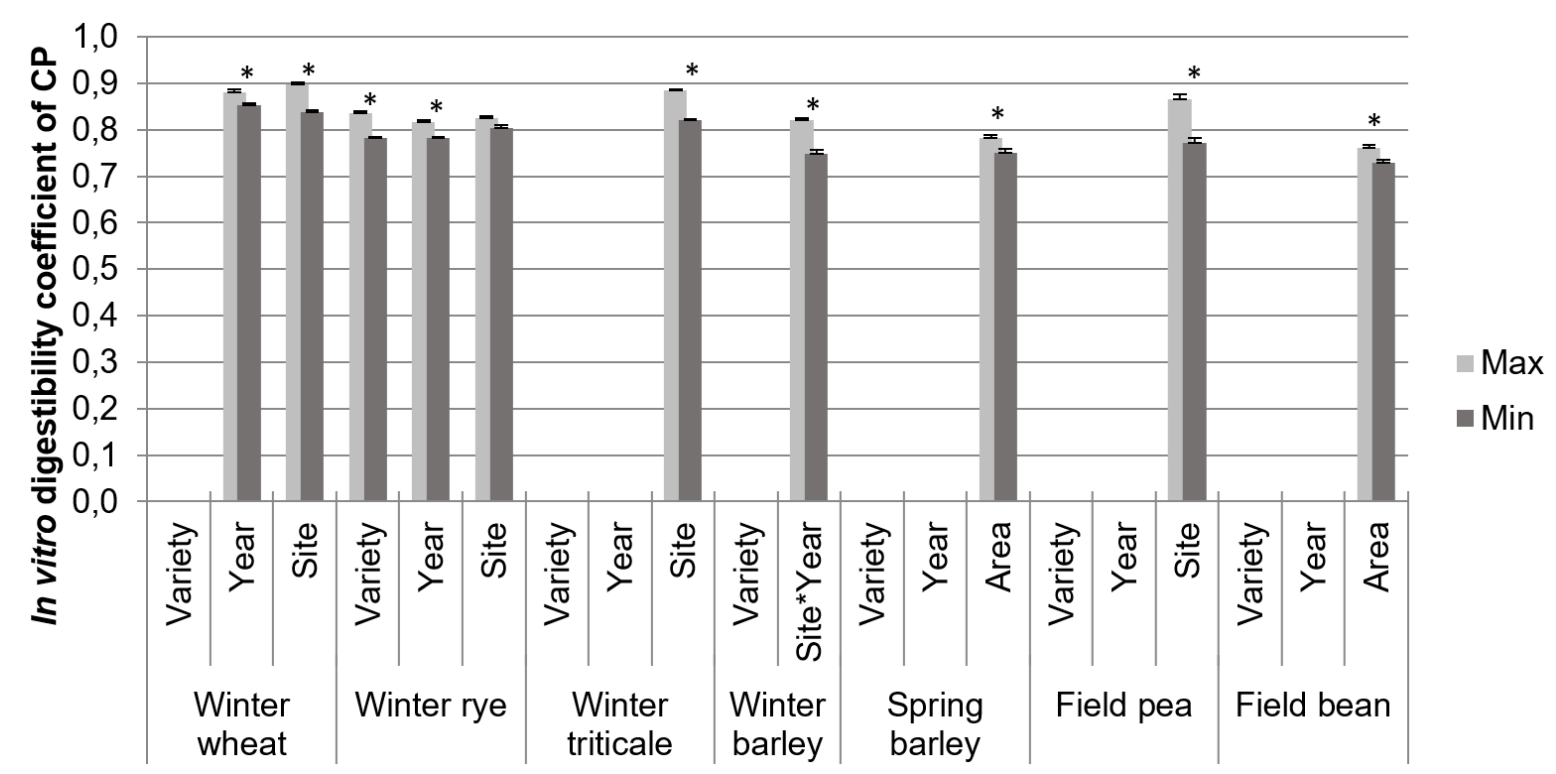

Figure IV 1: In vitro crude protein digestibility coefficient of selected cereals and grain legumes in 42-day old broiler chicken. Bars illustrate factor manifestations of variety, year, and harvest site or area with the minimum and maximum contents (Ismeans and standard errors), ${ }^{*}$ mark significant differences $(p<0.05)$. See Appendix for more detailed information.

\section{Discussion}

When compared to feed tables (Ajinomoto Animal Nutrition Group 2003-2013, Agroscope 2011-2016, Evonik 2016, INRA-CIRAD-AFZ 2018), the ranking of the CP digestibility among cultivars was as it would be expected. The in vitro digestibility coefficients varied widely in each cultivar and especially in the grain legume cultivars. This was probably due to a large number of samples from different varieties, harvest sites, and harvest years with varying concentrations of nutrients (Chapter I) and possibly also anti-nutrients (Guillamón et al. 2008). However, wide variations of the pc CP and AA digestibility can also be observed within and among table values and different studies.

When the equations were used that predict the standardised pc digestibility of CP and AA for 21-day old broiler chicken, the in vitro digestibility coefficients were very high. The prediction of the standardised pc digestibility of CP and AA in 42-day old broiler chicken was more realistic in comparison to table values. Thus, the in vitro digestibility of CP and AA for 42-day old broiler chicken is further discussed in this chapter.

Wheat showed the highest digestibility coefficients followed by triticale. Most of the in vitro $\mathrm{CP}$ and $\mathrm{AA}$ digestibility coefficients for these cultivars were comparable to the digestibility coefficients reported by Lemme et al. (2004), Bandegan et al. (2011), Ajinomoto Animal Nutrition Group (2003-2013), Evonik (2016), and INRA-CIRAD-AFZ (2018). Nevertheless, the pc digestibility of some AA, including Lys and Arg, in wheat and triticale might be overestimated by the in vitro assay. The variability was high between the 47 wheat samples used in the present study. However, Owens et al. (2009), who studied 61 wheat samples, 
and Bryden et al. (2009), who studied 27 wheat samples, reported even wider variations of the apparent pc digestibility of CP. The apparent pc digestibility coefficients of Met differed by up to 0.22 in wheat samples described by Bryden et al. (2009).

The in vitro CP and Lys digestibility of barley was in accordance with the standardised pc digestibility of $\mathrm{CP}$ and $\mathrm{AA}$ of five barley samples from a study conducted by Bandegan et al. (2011). Furthermore, the in vitro CP and AA digestibility was comparable to reported digestibility coefficients of Ajinomoto Animal Nutrition Group (2003-2013), but lower than the standardised pc digestibility of AA of barley reported by Evonik (2016) and INRACIRAD-AFZ (2018). Since there is no information on the difference between winter and spring varieties regarding their $\mathrm{CP}$ and $\mathrm{AA}$ digestibility, the statistically significant difference between winter and spring barley cannot be extensively discussed. It is surprising that the in vitro $\mathrm{CP}$ and $\mathrm{AA}$ digestibility coefficients of winter barley were higher, since the content of crude fibre was also significantly higher in winter barley (Chapter I) and crude fibre was reported to have a detrimental effect on the nutrient digestibility (Jørgensen et al. 1996). However, cereal proteins consist of different protein fractions of which some are less digestible than others (Carbonaro et al. 2000, Rubio et al. 2013). Significantly lower amounts of Arg, Asp, Lys, Leu, lle, and Val in the CP of winter barley in comparison to spring barley (see Chapter I) indicate an altered protein composition, which might have affected the in vitro CP digestibility. In accordance with the results of the present study, Büchmann (1979) observed wide variations of the in vitro digestibility in 321 spring barley lines, which depended on fertilisation and, to a lesser extent, on genetic and environmental differences.

Little information is given on the pc digestibility of rye. The standardised pc digestibility of the essential AA of winter rye reported in Evonik (2016) was in accordance with the in vitro digestibility of the essential AA. However, Blok \& Dekker (2017) reported a lower pc digestibility of all AA except Met in winter rye $(n=2)$ than predicted in vitro in the present study and Zuber et al. (2016b) found the apparent pc digestibility of the AA of rye to be very low in hens. This might be due to non-starch polysaccharides (NSP) and pentosans, which can negatively affect the nutrient absorption due to a viscous chyme (Almirall et al. 1995). However, the in vitro rate of disappearance would not necessarily be affected by these compounds (Moughan 1999). The rye sample, for which the pc CP and AA digestibility was known, could not be used in the calibration of the in vitro method (Chapter III). Due to the results of the present follow-up study, the assay cannot be recommended to be used with rye samples as yet. The in vitro digestibility coefficient can be used, nevertheless, to rank winter rye samples according to their possibly digestible CP and AA at the terminal ileum. The assay might be further adaptable when more rye samples with known in vivo pc digestibility of $\mathrm{CP}$ and $\mathrm{AA}$ are available. 
The field bean sample used for the calibration of the in vitro method had surprisingly higher digestible CP and AA contents than the field pea sample (Chapter II). Conversely, as was expected (Masey O'Neill et al. 2012, Koivunen et al. 2016), the mean of the sample set showed that field beans contained a lower proportion of in vitro digestible CP and AA than field peas. This finding shows the potential of the in vitro assay for the prediction of the $\mathrm{pc}$ $\mathrm{CP}$ and $\mathrm{AA}$ digestibility of grain legumes. However, with the exception of Lys and Arg (and His in field peas), the in vitro CP and AA digestibility coefficients of field beans and field peas were comparable to the pc digestibility coefficients of seven field bean and six field pea varieties studied by Masey O'Neill et al. (2012), although they observed somewhat less variation. Nevertheless, the variation of the digestibility coefficients of CP and Lys varied by up to 0.16 and 0.20 , respectively, in the tables of Bryden et al. (2009). It could be suggested that the sample selection and the number of samples account for these differences. This makes a comparison with mean values difficult. When compared to mean values of the present study, positive and negative deviations from the mean in vitro AA digestibility coefficients can be observed for the pc digestibility of the AA of field beans and field peas reported by Evonik (2016). Ajinomoto Animal Nutrition Group (2003-2013) and INRA (2018) reported higher AA digestibility coefficients except for Met.

Differences of the CP and AA digestibility in swine and poultry between genotypes of cereals are known (Crépon et al. 2010, Rosenfelder et al. 2015, Spindler et al. 2016, Zuber et al. 2016, Zuber \& Rodehutscord 2016). In the sample set of the present study, winter rye was the only cultivar, in which the in vitro digestibility of CP and AA differed between varieties. However, the sample set of winter rye included the largest number of different varieties, was most balanced and the samples were grown in only four different harvest sites. These characteristics of the sample set might be the cause for observing effects of all three tested factors, but a small effect of the harvest site. Masey O'Neill et al. (2012) observed that variety only affected the standardised pc digestibility of Leu in field peas and of CP in field beans. Koivunen et al. (2016) also found only occasional varietal differences.

This leads to the assumption that the selection and the number of varieties was the reason for the absence of an effect of the variety in most studied cultivars. The test varieties were of equal value in cultivation and feeding. Consequently, the differences were small. A test with more varieties with differing characteristics might show an effect of this factor. Furthermore, environmental conditions could be overlapping with differences between varieties. The cultivation environment and management can largely affect the nutrient composition of crops (Longstaff \& McNab 1986, Zebarth et al. 1992, Metayer et al. 1993, Witten \& Aulrich 2018). For example is it possible that soil or weather, as well as the occurrence of pests and diseases during growth, affect the grain composition of crops (Shewfelt 1990, Gutiérrez-Alamo et al. 2008). Thus, it is plausible that digestibility can also 
be affected by environmental conditions. However, studies on this topic are scarce. Gehring et al. (2012) and Ravindran et al. (2014) reported that the source of corn or soybean meal, respectively, is an important influencing factor on the ileal nutrient digestibility. Simon (2004) studied the effects of two harvest sites and two varieties of field beans and blue lupins on the $\mathrm{pc} C P$ and $A A$ digestibility and found wide variations (up to 0.07). However, no significant differences of the $\mathrm{Pc} C \mathrm{CP}$ and $\mathrm{AA}$ digestibility between varieties or sites were observed in field beans while statistically significant differences between lupin varieties were detected. In other studies, the cultivation environment is not mentioned. For example, the wide variation of the $\mathrm{Pc} \mathrm{CP}$ digestibility as well as the effect of the variety on the $\mathrm{PC} \mathrm{CP}$ digestibility of three wheat varieties $(0.78-0.88$, Kluth et al. 2009) might have been affected by environmental conditions. The environmental conditions, including pests and diseases, during plant maturation have an impact on the actual formation of plant ingredients. In the present study, the harvest site or area had an even stronger impact on the in vitro CP and AA digestibility than the harvest year. Furthermore, the in vitro digestibility differed between harvest sites even when they were located in the same area of homogenous climatic conditions. This result indicates that characteristics of the site, including the cultivation management, not only affect the nutrient composition but also the CP and AA digestibility of cereals and grain legumes. Since varieties can adapt to production systems (Murphy et al. 2007), this effects might have been even stronger due to organic cultivation management.

\section{Conclusions}

This study confirms that the digestibility of $\mathrm{CP}$ and $\mathrm{AA}$ varies widely and is affected by the cultivar, the variety, and the environmental conditions. However, variations are largely depending on characteristics of the sample set. Since animal performance and health can be affected by these wide variations, valid predictions of the $\mathrm{pc}$ digestibility can be beneficial. The modified multi-enzyme assay to predict the pc CP and AA digestibility of feedstuffs for young broiler chicken led in many cases to plausible results. However, it is recommended to further improve the validity of the multi-enzyme assay for the prediction of the pc digestibility of CP and especially of AA using combined in vitro and in vivo studies. 


\section{References}

Agroscope (2011-2016). Feedbase - the Swiss Feed Database, https://www.feedbase.ch/, University of Zurich, Agroscope. Last access 25th of June 2018.

Ajinomoto Animal Nutrition Group (2003-2013). Ajinomoto Heartland (since April 2018 Ajinomoto Animal Nutrition North America) Amino Acid Database, http://aaa.lysine.com/, Last Acces 25th June 2018.

Almirall, M., Francesch, M., Perez-Vendrell, A.M., Brufau, J. and Esteve-Garcia, E. (1995). The Differences in Intestinal Viscosity Produced by Barley and B $\beta$-Glucanase Alter Digesta Enzyme Activities and lleal Nutrient Digestibilities More in Broiler Chicks Than in Cocks. Journal Nutr 125, 947-955. 10.1093/jn/125.4.947

Bandegan, A., Golian, A., Kiarie, E., Payne, R.L., Crow, G.H., Guenter, W. and Nyachoti, C.M. (2011). Standardized Ileal Amino Acid Digestibility in Wheat, Barley, Pea and Flaxseed for Broiler Chickens. Can J Anim Sci 91, 103-111. DOI: 10.4141/CJAS10076

Blok, M.C. and Dekker, R.A. (2017). Table 'Standardized lleal Digestibility of Amino Acids in Feedstuffs for Poultry'. Wageningen Livestock Research. DOI: 10.18174/426333

Bryden, W.L., Li, X., Ravindran, G., Hew, L.I. and Ravindran, V. (2009). Ileal Digestible Amino Acid Values in Feedstuffs for Poultry. Rural Industries Research and Development Corporation. ISBN: 1741518709

Büchmann, N.B. (1979). Variation in in Vitro Digestibility of Barley Protein. J Sci Food Agr 30, 590-596. DOI: $10.1002 /$ jsfa.2740300607

Calcagno, V. (2013). GImulti: Model Selection and Multimodel Inference Made Easy. R Package Version 1.0.7. https://cran.R-project.org/package=Glmulti.

Carbonaro, M., Grant, G., Cappelloni, M. and Pusztai, A. (2000). Perspectives into Factors Limiting in Vivo Digestion of Legume Proteins: Antinutritional Compounds or Storage Proteins? J Agric Food Chem 48, 742-749. DOI: $10.1021 / \mathrm{Jf9} 91005 \mathrm{~m}$

Crépon, K., Marget, P., Peyronnet, C., Carrouée, B., Arese, P. and Duc, G. (2010). Nutritional Value of Faba Bean (Vicia Faba L.) Seeds for Feed and Food. Field Crop Res 115, 329-339. DOI: 10.1016/j.fcr.2009.09.016

Elbers, A.R.W., Den Hartog, L.A., Verstegen, M.W.A. and Zandstra, T. (1989). Between- and within-Herd Variation in the Digestibility of Feed for Growing-Finishing Pigs. Livest Prod Sci 23, 183-193. DOI: 10.1016/0301-6226(89)90013-4

Evonik (2016). Evonik Nutrition \& Care Gmbh. Aminodat 5.0, Version 1.03.

Gehring, C.K., Bedford, M.R., Cowieson, A.J. and Dozier, W.A. (2012). Effects of Corn Source on the Relationship between in Vitro Assays and Ileal Nutrient Digestibility. Poult Sci 91, 1908-1914. DOI: $10.3382 / p s .2012-02175$

Guillamón, E., Pedrosa, M.M., Burbano, C., Cuadrado, C., de Cortes Sánchez, M. and Muzquiz, M. (2008). The Trypsin Inhibitors Present in Seed of Different Grain Legume Species and Cultivar. Food Chem 107, 68-74. DOI:10.1016/j.foodchem.2007.07.029

Gutiérrez-Alamo, A., Pérez De Ayala, P., Verstegen, M.W.A., Den Hartog, L.A. and Villamide, M.J. (2008). Variability in Wheat: Factors Affecting Its Nutritional Value. World Poult Sci J 64, 20-39. DOI: 10.1017/S0043933907001699

Hoehler, D., Lemme, A., Ravindran, V., Bryden, W. and S. Rostagno, H. (2005). Feed Formulation in Broiler Chickens Based on Standardized Ileal Amino Acid Digestibility. In: Proceedings of the 3rd Mid-Atlantic Nutrition Conference, 78-91.

Hothorn, T., Bretz, F. and Westfall, P. (2008). Simultaneous Inference in General Parametric Models. Biom J 50, 346-363. DOI: 10.1002/bimj.200810425

Huang, K.H., Li, X., Ravindran, V. and Bryden, W.L. (2006). Comparison of Apparent lleal Amino Acid Digestibility of Feed Ingredients Measured with Broilers, Layers, and Roosters. Poult Sci 85, 625-634. DOI: $10.1093 / \mathrm{ps} / 85.4 .625$

Huang, K.H., Ravindran, V., Li, X. and Bryden, W.L. (2005). Influence of Age on the Apparent lleal Amino Acid Digestibility of Feed Ingredients for Broiler Chickens. $\mathrm{Br}$ Poult Sci 46, 236-245. DOI: 10.1080/00071660500066084

INRA-CIRAD-AFZ (2018). INRA-CIRAD-AFZ Feed Tables - Composition and Nutritive Values of Feeds for Cattle, Sheep, Goats, Pigs, Poultry, Rabbits, Horses and Salmonids, https://feedtables.com/, Last Access 1st August 2018.

Jezierny, D., Mosenthin, R., Sauer, N. and Eklund, M. (2010). In Vitro Prediction of Standardised lleal Crude Protein and Amino Acid Digestibilities in Grain Legumes for Growing Pigs. Animal 4, 1987-1996. DOI: $10.1017 / \mathrm{S} 1751731110001114$

JKI (2018). Julius-Kühn-Institute, Geoportal, http://geoportal.julius-kuehn.de/map?app=oeko. Last Access: 1st of August 2018. 
Jørgensen, H., Zhao, X.-Q., Knudsen, K.E.B. and Eggum, B.O. (1996). The Influence of Dietary Fibre Source and Level on the Development of the Gastrointestinal Tract, Digestibility and Energy Metabolism in Broiler Chickens. Br J Nutr 75, 379-395. DOI: 10.1079/BJN19960141

Kadim, I.T. and Moughan, P.J. (1997). Development of an Ileal Amino Acid Digestibility Assay for the Growing Chicken-Effects of Time after Feeding and Site of Sampling. Br Poult Sci 38, 89-95. DOI: $10.1080 / 00071669708417946$

Kadim, I.T., Moughan, P.J. and Ravindran, V. (2002). Ileal Amino Acid Digestibility Assay for the Growing Meat Chicken--Comparison of Ileal and Excreta Amino Acid Digestibility in the Chicken. Br Poult Sci 43, 588597. DOI: 10.1080/0007166022000004507

Kim, E.J. and Corzo, A. (2012). Interactive Effects of Age, Sex, and Strain on Apparent Ileal Amino Acid Digestibility of Soybean Meal and an Animal by-Product Blend in Broilers. Poult Sci 91, 908-917. DOI: $10.3382 / p s .2011-01820$

Kim, E.J., Utterback, P.L., Applegate, T.J. and Parsons, C.M. (2011). Comparison of Amino Acid Digestibility of Feedstuffs Determined with the Precision-Fed Cecectomized Rooster Assay and the Standardized Ileal Amino Acid Digestibility Assay. Poult Sci 90, 2511-2519. DOI: 10.3382/ps.2011-01400

Kluth, H., Fricke, M. and Rodehutscord, M. (2009). Precaecal Amino Acid Digestibility of Different Wheat Cultivars in Broilers. Arch Geflugelk 73, 80-86. ISSN 0003-9098

Kluth, H. and Rodehutscord, M. (2009). Standardisierte Futterbewertung Auf Der Basis Der Aminosäurenverdaulichkeit Beim Geflügel [Standardised Feed Evaluation on the Basis of the Amino Acid Digestibility in Poultry]. Uebers Tierern 37, 1.26.

Koivunen, E., Partanen, K., Perttilä, S., Palander, S., Tuunainen, P. and Valaja, J. (2016). Digestibility and Energy Value of Pea (Pisum Sativum L.), Faba Bean (Vicia Faba L.) and Blue Lupin (Narrow-Leaf) (Lupinus Angustifolius) Seeds in Broilers. Anim Feed Sci Tech 218, 120-127. DOI: 10.1016/j.anifeedsci.2016.05.007

Lemme, A., Ravindran, G. and Bryden, W.L. (2004). Ileal Digestibility of Amino Acids in Feed Ingredients for Broilers. World Poult Sci J 60, 423-438. DOI: 10.1079/WPS200426

Lenth, R.V. (2016). Least-Squares Means: The R Package Lsmeans. J Stat Softw 69, 1-33. DOI: 10.18637/jss.v069.i01

Longstaff, M. and McNab, J.M. (1986). Influence of Site and Variety on Starch, Hemicellulose and Cellulose Composition of Wheats and Their Digestibilities by Adult Cockerels. Br Poult Sci 27, 435-449. DOI: $10.1080 / 00071668608416901$

Masey O'Neill, H.V., Rademacher, M., Mueller-Harvey, I., Stringano, E., Kightley, S. and Wiseman, J. (2012). Standardised Ileal Digestibility of Crude Protein and Amino Acids of Uk-Grown Peas and Faba Beans by Broilers. Anim Feed Sci Tech 175, 158-167. DOI: 10.1016/j.anifeedsci.2012.05.004

Metayer, J.P., Grosjean, F. and Castaing, J. (1993). Study of Variability in French Cereals. Anim Feed Sci Tech 43, 87-108. DOI: 10.1016/0377-8401(93)90145-A

Moughan, P.J. (1999). In Vitro Techniques for the Assessment of the Nutritive Value of Feed Grains for Pigs: A Review. Aust J Agr Res 50, 871-879. DOI: 10.1071/Ar98172

Murphy, K.M., Campbell, K.G., Lyon, S.R. and Jones, S.S. (2007). Evidence of Varietal Adaptation to Organic Farming Systems. Field Crops Res 102, 172-177. DOI: 10.1016/j.fcr.2007.03.011

Owens, B., McCann, M.E.E., McCracken, K.J. and Park, R.S. (2009). Prediction of Wheat Chemical and Physical Characteristics and Nutritive Value by near-Infrared Reflectance Spectroscopy. Br Poult Sci 50, 103-122. DOI: 10.1080/00071660802635347

Ravindran, V., Abdollahi, M.R. and Bootwalla, S.M. (2014). Nutrient Analysis, Metabolizable Energy, and Digestible Amino Acids of Soybean Meals of Different Origins for Broilers. Poult Sci 93, 2567-2577. DOI: 10.3382/ps.2014-04068

R Core Team (2017). R: A Language and Environment for Statistical Computing, Version 3.4.0. http://www.Rproject.org/, R Foundation for Statistical Computing, Vienna, Austria.

Ritteser, C. (2015). Bestimmung präcecaler Verdaulichkeitskoeffizienten für Heimische Energie- und Proteinfuttermittel für die Bio-Hühnermast [Estimation of lleal Nutrient Digestibility of Native Energy and Protein Feeding Stuffs for Organic Broilers]. Dissertation, University of Hohenheim.

Rodehutscord, M., Rückert, C., Maurer, H.P., Schenkel, H., Schipprack, W., Bach Knudsen, K.E., Schollenberger, M., Laux, M., Eklund, M., Siegert, W. and Mosenthin, R. (2016). Variation in Chemical Composition and Physical Characteristics of Cereal Grains from Different Genotypes. Arch Anim Nutr 70, 87-107. DOI: 10.1080/1745039X.2015.1133111

Rosenfelder, P., Mosenthin, R., Spindler, H.K., Jørgensen, H., Bach Knudsen, K.E., Sauer, N., Htoo, J.K. and Eklund, M. (2015). Standardized Ileal Digestibility of Amino Acids in Eight Genotypes of Soft Winter Wheat Fed to Growing Pigs. Anim Sci 93, 1133-1144. DOI: 10.2527/jas.2014-8079 
Rubio, L.A., Pérez, A., Ruiz, R., Guzmán, M.Á., Aranda-Olmedo, I. and Clemente, A. (2013). Characterization of Pea (Pisum Sativum) Seed Protein Fractions. J Sci Food Agr 94, 280-287. DOI:10.1002/jsfa.6250

Shewfelt, R.L. (1990). Sources of Variation in the Nutrient Content of Agricultural Commodities from the Farm to the Consumer. J Food Qual 13, 37-54. DOI: 10.1111/j.1745-4557.1990.tb00004.x

Sibbald, I.R. (1987). Estimation of Bioavailable Amino-Acids in Feedingstuffs for Poultry and Pigs - a Review with Emphasis on Balance Experiments. Can J Anim Sci 67, 221-301. ISSN: 0800-3984

Simon, A. (2004). Praecaecale Aminosäurenverdaulichkeit von Ackerbohnen und Blauen Lupinen bei Broilern [Precaecal Amino Acid Digestibility of Field Beans and Blue Lupins in Broiler Chicken], http://www.ufop.de/files/3013/3922/7331/Praecaecale Verdaulichk.pdf, Last Access 4the of June 2018, UFOP Reports, Humboldt-Universität Berlin, Berlin.

Spindler, H.K., Mosenthin, R., Rosenfelder, P., Jørgensen, H., Bach Knudsen, K.E., Sauer, N., Htoo, J.K. and Eklund, M. (2016). Standardized Ileal Digestibility of Amino Acids in Eight Genotypes of Barley Fed to Growing Pigs. Animal 10, 1931-1940. DOI: 10.1017/S175173111600104X

Strang, E.J.P., Eklund, M., Rosenfelder, P., Sauer, N., Htoo, J.K. and Mosenthin, R. (2016). Chemical Composition and Standardized Ileal Amino Acid Digestibility of Eight Genotypes of Rye Fed to Growing Pigs. Anim Sci 94, 3805-3816. DOI: 10.2527/jas.2016-0599

Wallis, I.R. and Balnave, D. (1984). The Influence of Environmental Temperature, Age and Sex on the Digestibility of Amino Acids in Growing Broiler Chickens. Br Poult Sci 25, 401-407. DOI: $10.1080 / 00071668408454880$

Witten, S. and Aulrich, K. (2018). Effect of Variety and Environment on the Amount of Thiamine and Riboflavin in Cereals and Grain Legumes. Anim Feed Sci Tech 238, 39-46. DOI: 10.1016/j.anifeedsci.2018.01.022

Zebarth, B.J., Warren, C.J. and Sheard, R.W. (1992). Influence of the Rate of Nitrogen Fertilization on the Mineral Content of Winter Wheat in Ontario. J Agric Food Chem 40, 1528-1530. DOI: 10.1021/jf00021a011

Zeileis, A. (2004). Econometric Computing with HC and HAC Covariance Matrix Estimators. J Stat Softw 11, 117. DOI: $10.18637 /$ jss.v011.i10

Zhang, L., Liu, L., Li, D., Li, Q., Piao, X., Thacker, P.A., Brown, M.A. and Lai, C. (2017). Effects of Variety and Storage Duration on the Nutrient Digestibility and the Digestible and Metabolisable Energy Content of Maize Fed to Growing Pigs. Arch Anim Nutr 71, 67-80. DOI: 10.1080/1745039X.2016.1226034

Zuber, T., Miedaner, T., Rosenfelder, P. and Rodehutscord, M. (2016). Amino Acid Digestibility of Different Rye Genotypes in Caecectomised Laying Hens. Arch Anim Nutr 70, 470-487. DOI: $10.1080 / 1745039 x .2016 .1226035$

Zuber, T. and Rodehutscord, M. (2016). Variability in Amino Acid Digestibility of Wheat Grains from Diverse Genotypes Examined in Caecectomised Laying Hens. Europ Poult Sci 80. DOI: 10.1399/eps.2016.156 


\section{Chapter V}

\section{Effect of variety and environment on the amount of thiamine and riboflavin in cereals and grain legumes}

Einfluss von Sorte und Umwelt auf die Gehalte an Thiamin und Riboflavin in

Getreide und Körnerleguminosen

Stephanie Witten, Karen Aulrich

Johann Heinrich von Thünen-Institute, Institute of Organic Farming,

Trenthorst 32, 23847 Westerau, Germany

Witten, S., Aulrich, K. 2018 Effect of variety and environment on the amount of thiamine and riboflavin in cereals and grain legumes. Anim Feed Sci Tech 238, 39-46.

DOI: 10.1016/j.anifeedsci.2018.07.001 


\begin{abstract}
Comprehensive information on B vitamin contents in cereals and grain legumes used for animal feeding is scarce. Thus, the objective of this study was to determine the contents of thiamine and riboflavin uniformly in a selection of cereals and grain legumes. Additionally, the evaluation of varietal and environmental effects on the amounts of both $B$ vitamins was targeted. We analysed contents of thiamine and riboflavin with HPLC in 855 samples of different organically cultivated cereal and grain legume cultivars. Since the sample set was unbalanced, it had to be adapted for further statistical analyses. Data of 541 samples of ten cereal and grain legume cultivars was used to assess the influence of variety and environment with generalised linear models. Cereal grains contained $1.27-3.53 \mathrm{mg}$ thiamine and 0.62 - $1.58 \mathrm{mg}$ riboflavin/ $\mathrm{kg} \mathrm{DM}$, which was less than expected from table values. Thiamine and riboflavin contents of grain legumes were mostly comparable with table values. Their thiamine contents ranged from 2.55 to $8.97 \mathrm{mg}$ and their riboflavin contents from 1.00 to $3.84 \mathrm{mg} / \mathrm{kg}$ DM. Furthermore, variety, harvest site, and/or year affected $B$ vitamin contents in all cultivars of our sample set. Due to wide variations of the contents of thiamine and riboflavin, we recommend to express values in food- and feed tables as ranges and to mention the number of underlying analysed samples. It must be considered that thiamine contents of cereal grains might be lower than expected from foodand feed tables.
\end{abstract}

Keywords

Organic farming, Vitamin $B_{1}$, Vitamin $B_{2}$ 


\section{Zusammenfassung}

Umfassende Informationen $\mathrm{zu}$ den B-Vitamingehalten von Getreide und Körnerleguminosen für die Fütterung landwirtschaftlicher Nutztiere sind rar. Daher war das Ziel dieser Untersuchung, die nativen Gehalte an Thiamin und Riboflavin in einer Auswahl von Getreide und Körnerleguminosen einheitlich zu bestimmen. Zusätzlich sollten Sortenund Umwelteffekte auf die Thiamin- und Riboflavingehalte untersucht werden. Zu diesem Zweck wurden 855 Proben von verschiedenen Getreide- und Körnerleguminosenarten mittels HPLC auf ihre Gehalte an Thiamin und Riboflavin untersucht. Da die Stichprobe stark unbalanciert war, musste sie für die weitere Auswertung angepasst werden. Ergebnisse von 541 Proben von 10 Getreide- und Körnerleguminosenkulturen wurden genutzt, um den Einfluss von Sorte und Umwelt mit generalisierten linearen Modellen zu untersuchen. Getreidekörner enthielten 1,27 - 3,53 mg Thiamin und 0,62 - 1,58 mg Riboflavin/kg T und unterschritten damit die Tabellenwerte. Die Gehalte beider B-Vitamine in den Körnerleguminosen waren vergleichbar mit Tabellenwerten und schwankten für Thiamin zwischen 2,55 und 8,97 mg und für Riboflavin zwischen 1,00 und 3,84 mg/kg T. Die B-Vitamingehalte aller Kulturarten wurden durch die Sorte und die Umwelt beeinflusst. Da sehr starke Schwankungen der Gehalte beobachtet werden konnten, wird empfohlen, Tabellenwerte unter der Angabe der zugrundeliegenden Probenzahl als Schwankungsbreiten und nicht als Mittelwerte anzugeben. Zudem muss in Betracht gezogen werden, dass die Thiamingehalte von Getreidekörnern geringer sein könnten, als erwartet.

\section{Schlüsselworte}

Ökologischer Landbau, Vitamin $B_{1}$, Vitamin $B_{2}$ 


\section{Introduction}

Providing water-soluble vitamins with cereal-based diets for monogastric animals is challenging. Thiamine and riboflavin are important coenzymes in energy metabolism (Depeint et al. 2006, Fattal-Valevski 2011). Thus, deficiencies lead to decreased enzyme activity and therefore to health issues with specific symptoms, including decreased performance and even death (Blair \& Newsome 1985, Balk et al. 2016). Since the capacity of monogastric animals to store $B$ vitamins in the organism and to microbially synthesise them in the digestive tract is low, B vitamins must be fed continuously to prevent deficiencies (McDowell 2000).

However, comprehensive information on contents of thiamine and riboflavin in cereals and grain legumes used for animal feeding is scarce. Since B vitamin analyses are relatively expensive, native amounts in the feed are usually not determined. Most values used even in food and feed tables (Sauvant et al. 2004, Souci et al. 2008, USDA 2016) originate from early studies. There have not been representative analyses of B-vitamins in cereal and legume grains for a long time. Furthermore, underlying laboratory methods are often unknown. Various methods used to determine B vitamins can lead to different results (Hollman et al. 1993). Besides differences arising from analytical methods, environmental and genetic factors might also affect the actual contents of $B$ vitamins in plant material (Bognar \& Kellermann 1993, Shewry et al. 2011). Moreover, storage conditions (Bayfield \& O'Donnell 1945, Finglas 2003) or further processing (Gołda et al. 2004, Lebiedzińska \& Szefer 2006) can alter the amounts of B vitamins.

The objective of this study was to determine the contents of thiamine and riboflavin uniformly in a selection of cereals and grain legumes. We also wanted to evaluate varietal and environmental (harvest year and harvest site) effects on the contents of $B$ vitamins in some cereals and grain legumes.

\section{Materials and Methods}

\section{Sample set}

Organically managed variety field trials of cereals and grain legumes are undertaken throughout Germany by independent institutions. Those institutions collected a selection of 855 available harvest samples of cereals and grain legumes from trials in the years 2011 2012, and 2013.

\section{Laboratory analyses}

Immediately after harvesting samples were sent to the laboratory of the Institute of Organic Farming. Impure samples were cleaned using an air separator. We did not further process them before they were dried at $40^{\circ} \mathrm{C}$, ground to pass a $0.5 \mathrm{~mm}$ sieve, and stored in the dark 
at $8^{\circ} \mathrm{C}$. Contents of thiamine and riboflavin were analysed using high-performance liquid chromatography methods (HPLC) with fluorescence detection (FLD) according to EN14122 (2014) and EN14152 (2014). Oxidation of thiamine to thiochrome was necessary for FLD. We used the pre-column derivatisation for thiamine.

An Agilent 1260 Infinity HPLC system equipped with an FLD (Waldbronn, Germany) was used for analytical HPLC separations. Reversed-phase chromatography was performed using a SecurityGuard ${ }^{\text {TMS}}$ Standard Gemini-NX C18 pre-column (Phenomenex, Aschaffenburg, Germany) and a Kinetex 5.0 um C18 column (150 x 4.6 mm, Phenomenex, Aschaffenburg, Germany). A volume of $20 \mu$ l was injected.

Thiochrome separation was performed at a column temperature of $25^{\circ} \mathrm{C}$ and a flow rate of $0.8 \mathrm{ml} / \mathrm{min}$. The mobile phase consisted of methanol and $0.5 \mathrm{M}$ sodium acetate $(30 / 70 \mathrm{v} / \mathrm{v}$, isocratic conditions, $\mathrm{pH}$ 5.2). The FLD operated at an excitation wavelength of $366 \mathrm{~nm}$ and an emission wavelength of $435 \mathrm{~nm}$. The results were expressed as the total thiamine using the factor 0.787 for conversion from thiamine hydrochloride to thiamine.

Riboflavin was analysed at a flow rate of $1 \mathrm{ml} / \mathrm{min}$ at $35^{\circ} \mathrm{C}$. The mobile phase consisted of a phosphate buffer (5 mM potassium dihydrogen phosphate, $10 \mathrm{mM}$ sodium heptanesulfonate, $36 \mathrm{mM}$ trimethylamine, $\mathrm{pH}$ 3.0) and 60\% methanol. We ran the system with a binary gradient as shown in Table $V 1$. The FLD operated at an excitation wavelength of $468 \mathrm{~nm}$ and an emission wavelength of $520 \mathrm{~nm}$.

Table V 1: Chromatographic gradient conditions for the analysis of riboflavin

\begin{tabular}{|c|c|c|}
\hline Time (min) & Eluent $\mathrm{A}^{1}$ & Eluent $\mathrm{B}^{2}$ \\
\hline 0 & 95 & 5 \\
\hline 3 & 95 & 5 \\
\hline 12 & 53 & 47 \\
\hline 12.1 & 2 & 98 \\
\hline 17 & 2 & 98 \\
\hline 17.1 & 95 & 5 \\
\hline 25 & 95 & 5 \\
\hline
\end{tabular}

\section{Statistics}

All statistical analyses were conducted using R 3.4.0 (R Core Team 2017). For each cultivar, mean, standard deviation, minimum and maximum (range) were determined using the complete dataset ( $n$ total in Table V 2). The relationships between $B$ vitamins were tested using Pearson correlation analyses (package PerformanceAnalytics) (Peterson \& Carl 2014).

We used Wilcoxon rank sum tests to compare B vitamin contents in cereals with contents in grain legumes. Residuals of a combined data set containing all grain legume samples for a comparison between cultivars were not normally distributed. Thus, Wilcoxon rank sum tests were also used to compare the B vitamin contents of grain legume cultivars. 
Generalised linear models $(\mathrm{glm})$ were used to identify the effects of cultivar on thiamine and riboflavin contents in cereals.

An uneven availability of samples resulted in an unbalanced sample set for each cultivar. For our analysis, we used variety, site, and harvest year as factors. The following adjustments of the dataset were necessary to enable further analyses regarding the influence of variety, year, and site on the contents of B vitamins:

- When cultivars were harvested on many different sites with few repetitions, the sites were aggregated into areas with homogenous climatic conditions in Germany according to JKI (2018). This aggregation was used for winter triticale, winter wheat, spring barley, spring wheat, and spring field bean.

- Factor level manifestations were not taken into consideration when less than four repetitions were present.

- The repetitions of a factor (variety, year, and site/area) had to include a minimum of two manifestations of the other two factors.

Steps two and three reduced our sample set to a subset containing the factors variety, year, and harvest site or area (Table V 2). In contrast to all other cultivars, for winter barley only variety and site were used as factors, because three varieties were available from five different trials (harvest site*year) in a balanced dataset.

GIm were implemented on the adjusted data sets ( $n$ subset) to assess influences of the main factors variety, year, and site or area. Interactions could not be tested due to the unbalanced data and the absence of field replicates. The package glmulti (Calcagno 2013) was used to evaluate the best fitting models with only main factors by Akaike's Information Criterion with correction for sample size (AICc). Residuals of glm were checked for normal distribution with Shapiro-Wilk-Tests. When necessary, a model transformation was added for a better fit. Furthermore, influential data points were viewed to find outliers. To assess the stability of a model, it was tested whether a deletion of influential data points in the model effectively altered the outcome of the following analyses of variance. 
Table V 2: Total number of samples ( $\mathrm{n}$ total), number of samples considered for further statistical analyses ( $n$ subset), and number of factor manifestations for each cultivar

\begin{tabular}{|c|c|c|c|c|c|c|}
\hline & $\begin{array}{l}\bar{\pi} \\
\stackrel{\sigma}{0} \\
c\end{array}$ & 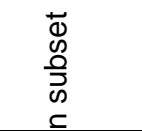 & 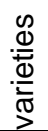 & $\begin{array}{l}\stackrel{\infty}{\mathbb{N}} \\
\stackrel{D}{D}\end{array}$ & $\stackrel{\mathscr{D}}{\frac{D}{\infty}}$ & 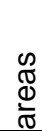 \\
\hline \multicolumn{7}{|l|}{ Cereals } \\
\hline Winter wheat (Triticum aestivum L.) & 106 & 70 & 3 & 3 & & 5 \\
\hline Spring wheat (Triticum aestivum L.) & 45 & 25 & 4 & 3 & & 3 \\
\hline Winter rye (Secale cereale L.) & 106 & 81 & 5 & 3 & 7 & \\
\hline Winter triticale (Triticosecale) & 107 & 92 & 7 & 3 & & 5 \\
\hline Spring triticale (Triticosecale) & 3 & - & & & & \\
\hline Winter barley (Hordeum vulgare L.) & 30 & 15 & 3 & 2 & 5 & \\
\hline Spring barley (Hordeum vulgare L.) & 66 & 47 & 4 & 3 & & 4 \\
\hline Oats (Avena sativa L.) & 105 & 80 & 7 & 3 & 6 & \\
\hline Naked barley (Hordeum vulgare L., var nudum) & 1 & - & & & & \\
\hline Naked oats (Avena sativa L., var nuda) & 1 & - & & & & \\
\hline \multicolumn{7}{|l|}{ Grain legumes } \\
\hline Spring field pea (Pisum sativum L.) & 87 & 41 & 6 & 3 & 4 & \\
\hline Spring field bean (Vicia faba L.) & $73 / 82^{*}$ & $57 / 59^{*}$ & 6 & 2 & & 3 \\
\hline Blue lupin (Lupinus angustifolius L.) & 110 & 31 & 5 & 3 & 3 & \\
\hline Yellow lupin (Lupinus luteus L.) & 4 & - & & & & \\
\hline Winter field pea (Pisum sativum L.) & 1 & - & & & & \\
\hline Winter field bean (Vicia faba L.) & 1 & - & & & & \\
\hline Total & $846 / 855^{*}$ & $539 / 541^{*}$ & & & & \\
\hline
\end{tabular}

Multiple comparisons were calculated using multcomp package (Hothorn et al. 2008) with least square means (Ismeans; Lenth 2016) and Bonferroni-Holm adjustment. The package sandwich (Zeileis 2004) was included for a heteroscedasticity and autocorrelation consistent estimation of covariance with robust standard errors (vcovHAC). We also calculated the maximum differences in thiamine and riboflavin contents between the factor manifestations for each cultivar.

\section{Results}

\section{Vitamin contents in cereals and grain legumes}

Grain legumes exceeded cereal grains significantly regarding thiamine and riboflavin contents. In cereal grains, winter rye and winter wheat had the lowest amounts of thiamine and riboflavin, respectively (Table $\vee 3$ ).

Oats contained high amounts of both B vitamins, but rye had the highest content of riboflavin. In grain legumes, the thiamine content was significantly higher in field peas than in field beans and blue lupins. The riboflavin content was significantly higher in field beans than in blue lupins and field peas. Ranges of $B$ vitamin contents were wide within most of the cultivars and especially within grain legume cultivars. Contents of thiamine and riboflavin in single samples of naked barley, winter field peas, winter field beans, and yellow lupins were in the same range as the ones of barley, spring field peas, spring field beans, and blue lupins, while naked oats had high contents of both B vitamins (Table A V 1 in the appendix). 
The amount of thiamine was positively correlated with the amount of riboflavin in blue lupins $\left(R^{2}=0.48, n=110, p=1.051 e^{-07}\right)$ and winter barley $\left(R^{2}=0.44, n=30, p=0.016\right)$.

Table V 3: Contents of thiamine and riboflavin in different cereal and legume grains [mg/kg DM]

\begin{tabular}{|c|c|c|c|c|}
\hline \multicolumn{2}{|l|}{ Cereale a d } & $\mathrm{n}$ & Thiamine & Riboflavin \\
\hline Cereals & & & & \\
\hline $\begin{array}{l}\text { Winter wheat } \\
\text { Triticum aestivum L. }\end{array}$ & $\begin{array}{l}\text { Mean } \pm \text { SD } \\
\text { Range }\end{array}$ & 106 & $\begin{array}{l}2.31 \pm 0.27^{c} \\
1.61-2.96\end{array}$ & $\begin{array}{c}0.74 \pm 0.06^{\mathrm{a}} \\
0.62-0.89\end{array}$ \\
\hline $\begin{array}{l}\text { Spring wheat } \\
\text { Triticum aestivum L. }\end{array}$ & $\begin{array}{l}\text { Mean } \pm \text { SD } \\
\text { Range }\end{array}$ & 45 & $\begin{array}{c}2.22 \pm 0.27^{\mathrm{bc}} \\
1.58-2.80\end{array}$ & $\begin{array}{c}0.85 \pm 0.12^{\mathrm{b}} \\
0.69-1.19\end{array}$ \\
\hline $\begin{array}{l}\text { Winter rye } \\
\text { Secale cereale L. }\end{array}$ & $\begin{array}{l}\text { Mean } \pm \text { SD } \\
\text { Range }\end{array}$ & 106 & $\begin{array}{l}1.76 \pm 0.3^{a} \\
1.16-2.35\end{array}$ & $\begin{array}{c}1.06 \pm 0.10^{d} \\
0.84-1.28\end{array}$ \\
\hline $\begin{array}{l}\text { Winter triticale } \\
\text { Triticosecale }\end{array}$ & $\begin{array}{l}\text { Mean } \pm \text { SD } \\
\text { Range }\end{array}$ & 107 & $\begin{array}{l}1.83 \pm 0.24^{a} \\
1.27-2.38\end{array}$ & $\begin{array}{c}0.91 \pm 0.11^{\mathrm{bc}} \\
0.65-1.17\end{array}$ \\
\hline $\begin{array}{l}\text { Winter barley } \\
\text { Hordeum vulgare L. }\end{array}$ & $\begin{array}{l}\text { Mean } \pm \text { SD } \\
\text { Range }\end{array}$ & 30 & $\begin{array}{c}2.21 \pm 0.30^{\mathrm{bc}} \\
1.76-3.01\end{array}$ & $\begin{array}{c}0.80 \pm 0.11^{\mathrm{abc}} \\
0.65-1.06\end{array}$ \\
\hline $\begin{array}{l}\text { Spring barley } \\
\text { Hordeum vulgare } \mathrm{L} .\end{array}$ & $\begin{array}{l}\text { Mean } \pm \text { SD } \\
\text { Range }\end{array}$ & 66 & $\begin{array}{l}2.05 \pm 0.31^{1 \mathrm{ab}} \\
1.27-2.64\end{array}$ & $\begin{array}{c}0.94 \pm 0.10^{c} \\
0.79-1.22\end{array}$ \\
\hline $\begin{array}{l}\text { Oats } \\
\text { Avena sativa L. }\end{array}$ & $\begin{array}{l}\text { Mean } \pm \text { SD } \\
\text { Range }\end{array}$ & 105 & $\begin{array}{c}2.71 \pm 0.39^{d} \\
1.87-3.53 \\
\end{array}$ & $\begin{array}{c}1.00 \pm 0.15^{\mathrm{cd}} \\
0.71-1.54 \\
\end{array}$ \\
\hline $\begin{array}{l}\text { Grain legumes } \\
\text { Spring field pea } \\
\text { Pisum sativum L. }\end{array}$ & $\begin{array}{l}\text { Mean } \pm \text { SD } \\
\text { Range }\end{array}$ & 87 & $\begin{array}{l}5.82 \pm 1.31^{b} \\
2.66-9.56\end{array}$ & $\begin{array}{c}1.73 \pm 0.22^{\mathrm{a}} \\
1.00-2.28\end{array}$ \\
\hline $\begin{array}{l}\text { Spring field bean } \\
\text { Vicia faba } \mathrm{L} \text {. }\end{array}$ & $\begin{array}{l}\text { Mean } \pm \text { SD } \\
\text { Range }\end{array}$ & $73 / 82^{*}$ & $\begin{array}{l}4.97 \pm 1.19^{a} \\
2.55-7.37\end{array}$ & $\begin{array}{l}2.75 \pm 0.36^{c} \\
2.13-3.84\end{array}$ \\
\hline $\begin{array}{l}\text { Blue lupin } \\
\text { Lupinus angustifolius L. }\end{array}$ & $\begin{array}{l}\text { Mean } \pm \text { SD } \\
\text { Range }\end{array}$ & 110 & $\begin{array}{l}4.91 \pm 1.00^{\mathrm{a}} \\
2.81-8.97\end{array}$ & $\begin{array}{c}2.39 \pm 0.25^{b} \\
1.94-3.05\end{array}$ \\
\hline
\end{tabular}

*thiamine/riboflavin; superscripts mark significant differences in columns $(P<0.05)$

\section{Effect of variety, harvest site, and harvest year}

Variety statistically affected B vitamin contents in cereals and grain legumes with some exceptions (Table $\vee 4$ ). In barley, field peas, and blue lupins the thiamine content did not differ between the observed varieties. The content of riboflavin was not affected by variety in winter barley, oats, and blue lupins. The environmental conditions, which were represented by harvest site/area and year, had an effect on all observed cultivars. Further detailed information can be found in the supplements (Tables A V $2-12$ in the Appendix). 


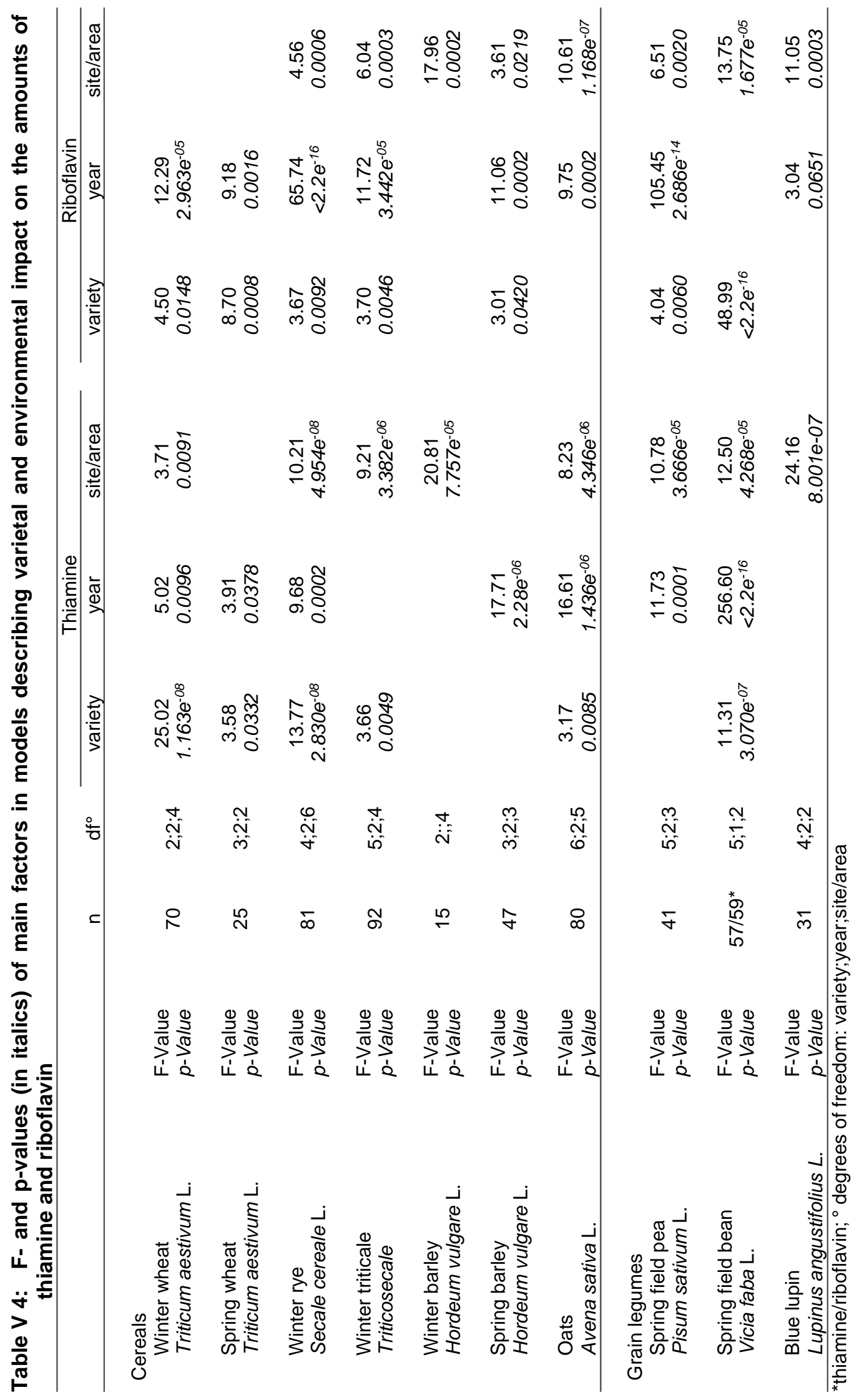




\section{Cereal grains}

The thiamine content differed between varieties of winter wheat, spring wheat, winter rye, and oats, respectively, by about $0.4 \mathrm{mg} / \mathrm{kg}$ DM (Figure $\mathrm{V} 1$ ). Differences of about $0.2 \mathrm{mg}$ thiamine/kg DM were observed between winter triticale varieties. Although statistically significant, the differences between the amounts of riboflavin in varieties of winter wheat, winter rye, winter triticale, and spring barley were rather low $(0.04-0.12 \mathrm{mg} / \mathrm{kg} \mathrm{DM})$. In the spring wheat variety Granny, the riboflavin contents were about $0.2 \mathrm{mg} / \mathrm{kg}$ DM higher than in the other observed varieties.

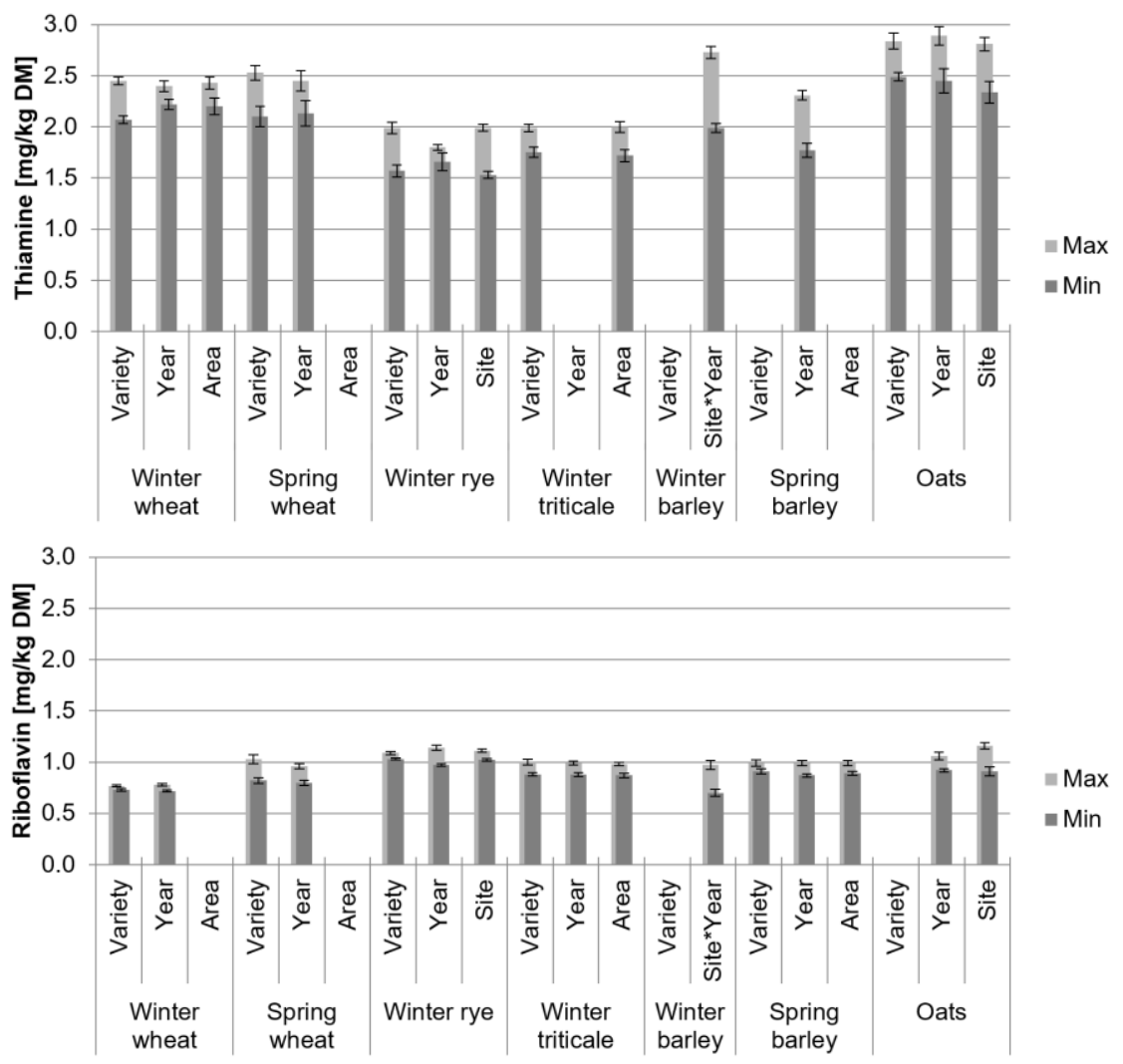

Figure V 1: Content of thiamine and riboflavin in cereal grains; Bars illustrate factor manifestations of variety, year, and harvest site or area with the minimum and maximum contents. See supplements for more detailed information

The amount of thiamine in winter triticale and winter barley did not differ between the years. However, there were maximum differences between the years of $0.2 \mathrm{mg}$ thiamine/kg DM in winter wheat, spring wheat, and winter rye, of $0.4 \mathrm{mg} / \mathrm{kg} \mathrm{DM}$ in oats and of $0.5 \mathrm{mg} / \mathrm{kg} \mathrm{DM}$ in spring barley. The riboflavin content of the winter variants was lowest in 2012, while the spring variants had the lowest riboflavin contents in 2013. The observed differences varied between 0.06 and $0.17 \mathrm{mg} / \mathrm{kg} \mathrm{DM}$.

While thiamine contents of spring wheat and spring barley were not affected by the harvest area, they differed by a maximum of 0.2 and $0.3 \mathrm{mg} / \mathrm{kg} \mathrm{DM}$ in winter wheat and winter triticale, respectively. We found wider variations of the thiamine content of winter rye and oats when harvest sites were compared. There was no impact of the harvest area on 
riboflavin contents of wheat. In winter triticale and spring barley as well as in winter rye was a difference of $0.1 \mathrm{mg}$ riboflavin $/ \mathrm{kg} \mathrm{DM}$ between harvest areas as well as harvest sites.

\section{Grain legumes}

We found wider variations of thiamine in grain legumes than in cereal grains (Figure V 2).
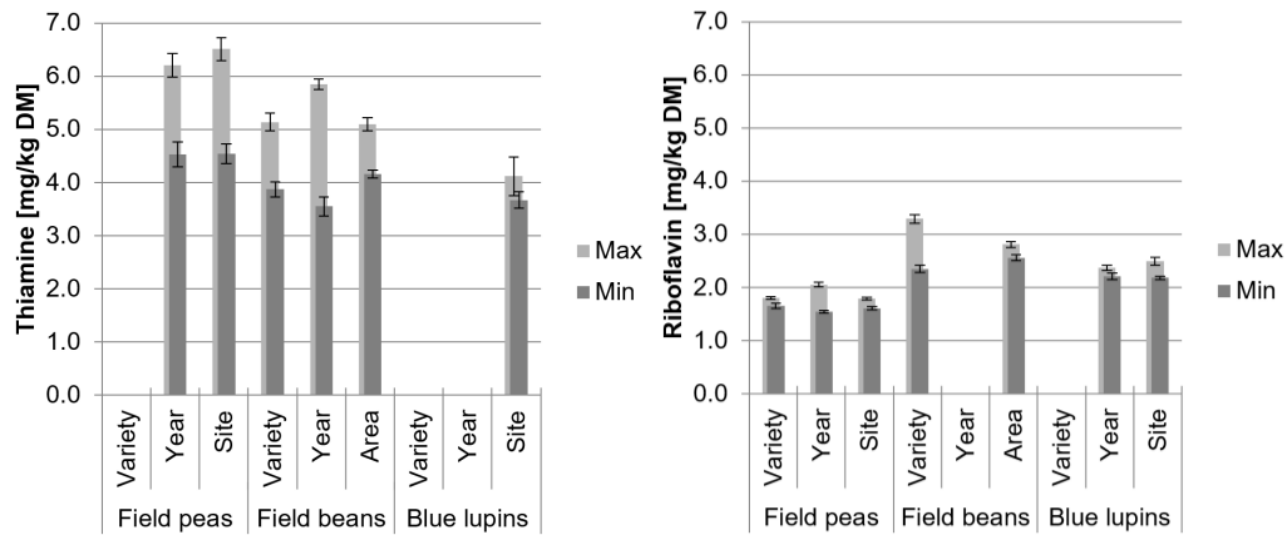

Figure V 2: Content of thiamine and riboflavin in grain legumes; Bars illustrate factor manifestations of variety, year, and harvest site or area with the minimum and maximum contents. See supplements for more detailed information

Our field peas for this evaluation were all semi-leafless, white-flowering varieties with smooth yellow seeds. Their thiamine content did not differ between varieties. However, there were differences of riboflavin content of up to $0.1 \mathrm{mg} / \mathrm{kg} \mathrm{DM}$ between varieties. While variety affected the contents of both $B$ vitamins strongly in field beans, it had no effect in blue lupins. With $3.3 \mathrm{mg} / \mathrm{kg}$ DM, high amounts of riboflavin were found in the field bean variety Alexia, while Divine contained only $2.4 \mathrm{mg}$ riboflavin $/ \mathrm{kg} \mathrm{DM}$.

In field peas, there were differences between the years of up to 1.7 and $0.5 \mathrm{mg}$ thiamine and riboflavin per $\mathrm{kg} \mathrm{DM}$, respectively. In our study, the thiamine content of field beans was predominantly affected by harvest year. Years differed by up to $2.3 \mathrm{mg}$ thiamine $/ \mathrm{kg} \mathrm{DM}$. In blue lupins year only affected the riboflavin content. However, when one influential measure was removed from the model for blue lupins, the factor year became nonsignificant.

While the thiamine content of field peas and field beans differed by up to 2.0 and $0.9 \mathrm{mg} / \mathrm{kg}$ $\mathrm{DM}$, respectively, between harvest sites, the riboflavin content differed by less than 0.2 $\mathrm{mg} / \mathrm{kg}$ DM. Blue lupins were primarily affected by harvest site.

\section{Discussion}

Due to the lack of knowledge about the origins of samples used for obtaining table values of $B$ vitamins as well as the utilised preparation procedures and analysis methods, comparisons of our results with table values can be deceptive. Differences between analysed B vitamin contents could arise due to many factors, such as varietal effects or environmental influences (Shewry et al. 2011) as well as varying methods used for analysis 
(Hollman et al. 1993). The most common analysing methods for B vitamins are microbiological assays and HPLC methods. Except for winter rye, our results showed slightly lower levels of thiamine in cereal grains than the findings of Buchholz et al. (2012), who themselves found comparably low thiamine contents in cereals. Sauvant et al. (2004) collected table values for feedstuffs and reported higher contents of both B vitamins in cereals. However, thiamine contents of the three grain legumes and riboflavin contents of field peas and field beans matched our results (Table 3 ). In the food tables of the USDA (2016), the amounts of both B vitamins in cereal grains were mostly higher than our findings. Only the thiamine contents of grain legumes as well as the riboflavin contents of field beans and oats equalled our results. Although table values of Sauvant et al. (2004) for blue lupins where higher, our riboflavin content was in accordance with the results of Olkowski (2008), who found $2.24 \mathrm{mg} / \mathrm{kg}$ DM. Piironen et al. (2009) reviewed even wider variations of $B$ vitamins in wheat grains. Overall, we found rather low mean amounts of both B vitamins in cereal grains and grain legumes. However, we expressed our thiamine results as thiamine. We do not know if other authors stated their results as thiamine chloride hydrochloride, as thiamine chloride (thiamine chloride hydrochloride ${ }^{*} 0.892$ ), or also as thiamine (thiamine chloride hydrochloride ${ }^{*} 0.787$ ). Thus, it is possible that our results are underestimated compared to the reviewed literature.

The variety and environmental conditions both affected B vitamin contents in cereals and grain legumes (Table 4). Differences were often rather small between factor manifestations and therefore lacked practical significance. However, results are dependent on the selected varieties and environments. Moreover, interactions of the factors are highly possible. Unfortunately, we were not able to test interactions within our data.

We could confirm results of O'Donnell (1943) as well as Nordgren \& Andrews (1941), who found that variety and environment affect thiamine content in wheat. Similarly to Conner \& Straub (1941), we observed that environment had a smaller effect on the riboflavin content in wheat than on its thiamine content. Although absolute measures differed greatly, our findings regarding the influence of variety and environment on wheat grains are also in accordance with Shewry et al. (2011). They found a larger genotypic variance of thiamine than riboflavin in wheat lines.

An effect of the harvest year on B vitamin contents in wheat and rye has previously been reported by Bognar \& Kellermann (1993). We could confirm this effect in our sample set in the years 2011-2013. Since high contents of thiamine and riboflavin in rye are located in the germ (Ihde \& Schuette 1941), varietal variations of grain size might have affected the amounts of $B$ vitamins. We found that rye variety Helltop, which has a very high corn mass, had a very high thiamine content, while its riboflavin content was similar to other varieties. 
In contrast to Michela \& Lorenz (1976), we found the B vitamin contents of winter triticale to be only roughly comparable to wheat and rye. However, the analysed results showed a considerably wide variation. Differences in B vitamin contents between sites in the same area as we found it in the case of oats can depend on local influences like cultivation management or weather. Since thiamine contents are known to decrease with an increasing degree of ripeness (Buchholz et al. 2012), harvest time can be one of the influencing factors. Moreover, mineral deficiencies are known to decrease riboflavin content in the leaves and tops of immature oat plants (Watson \& Noggle 1947). Thus, it can be suspected that mineral supply also affects the amount of riboflavin in oats and maybe even in other cereal grains.

Investigations of varietal differences of B vitamin contents in legumes are scarce. We did not find relevant information on field beans, field peas, and blue lupins. However, Burkholder \& McVeigh (1945) found varietal differences in soybeans and mung beans. In our sample set, we also found that the variety specifically influences the thiamine contents in field beans. Very high differences between the thiamine contents of field bean varieties lead to the assumption that breeding could alter them.

In blue lupins, growth type (determinate vs. indeterminate) did not have an influence on B vitamin contents. Variations of thiamine and riboflavin contents between the harvest sites might be primarily due to the differences in soil and weather.

\section{Conclusions}

We determined the contents of thiamine and riboflavin uniformly in a selection of cereals and grain legumes. Compared with food- and feed tables, we found rather low thiamine and riboflavin contents especially in cereal grains. It might be of interest to assess if thiamine contents in cereal grains are generally lower than would be expected. We observed an influence of variety, harvest year, and cultivation site on thiamine and riboflavin in cereals and grain legumes. Due to wide variations, it is difficult to estimate the amounts of both $B$ vitamins in samples of cereals and grain legumes. Thus, the use of mean values can be deceptive. It is recommended to express table values as ranges under the mention of the number of underlying samples and to make further analyses. Our data can be used to update existing food- and feed tables. 


\section{References}

Balk, L., Hägerroth, P.-Å., Gustavsson, H., Sigg, L., Åkerman, G., Ruiz Muñoz, Y., Honeyfield, D.C., Tjärnlund, U., Oliveira, K., Ström, K., McCormick, S.D., Karlsson, S., Ström, M., van Manen, M., Berg, A.-L., Halldórsson, H.P., Strömquist, J., Collier, T.K., Börjeson, H., Mörner, T. and Hansson, T. (2016). Widespread Episodic Thiamine Deficiency in Northern Hemisphere Wildlife. Sci Rep-Uk 6, 38821. DOI: $10.1038 /$ srep38821

Bayfield, E. G., and O'Donnell, W.W. (1945). Observations on Thiamin Content of Stored Wheat. J Food Sci 10, 485-488. DOI: 10.1111/j.1365-2621.1945.tb16196.x

Blair, R. and Newsome, F. (1985). Involvement of Water-Soluble Vitamins in Diseases of Swine. Anim Sci 60, 1508-1517. DOI: 10.2527/jas1985.6061508x

Bognar, A. and Kellermann, C. (1993). Vergleichende Untersuchungen über den Gehalt an Vitaminen in Dinkel, Weizen und Roggen [Comparative Investigations on the Content of Vitamins in Spelt, Wheat, and Rye]. Ernährungsforschung 38, 149-170.

Buchholz, M., Drotleff, A.M. and Ternes, W. (2012). Thiamin (Vitamin B1) and Thiamin Phosphate Esters in Five Cereal Grains During Maturation. J Cereal Sci 56, 109-114. DOI: 10.1016/j.jcs.2011.11.009.

Burkholder, P.R. and McVeigh, I. (1945). Vitamin Content of Some Mature and Germinated Legume Seeds. Plant Physiol 20, 301-306. DOI: 10.1104/pp.20.2.301

Calcagno, V. (2013). Glmulti: Model Selection and Multimodel Inference Made Easy. R Package Version 1.0.7. https://cran.R-project.org/package=Glmulti.

Conner, R.T. and Straub, G.J. (1941). The Thiamin and Riboflavin Contents of Wheat and Corn. Cereal Chem 18, 671-677.

Depeint, F., Bruce, W.R., Shangari, N., Mehta, R. and O'Brien, P.J. (2006). Mitochondrial Function and Toxicity: Role of the B Vitamin Family on Mitochondrial Energy Metabolism. Chem Biol Interact 163, 94-112. DOI: 10.1016/j.cbi.2006.04.014

EN14122 (2014). Din EN 14122:2014. Foodstuffs - Determination of Vitamin B1 by High Performance Liquid Chromatography (German Version).

EN14152 (2014). Din EN 14152:2014. Foodstuffs - Determination of Vitamin B2 by High Performance Liquid Chromatography (German Version).

Fattal-Valevski, A. (2011). Thiamine (Vitamin B1). J Evid Based Complementary Altern Med 16, 12-20. DOI: $10.1177 / 1533210110392941$

Finglas, P.M. (2003). Vitamins, In: Caballero, B., Finglas, P. M., Trugo, L. C. (Ed.), Encyclopedia of Food Sciences and Nutrition, pp. 6046-6053. ISBN: 978-0-12-227055-0

Gołda, A., Szyniarowski, P., Ostrowska, K., Kozik, A. and Rąpała-Kozik, M. (2004). Thiamine Binding and Metabolism in Germinating Seeds of Selected Cereals and Legumes. Plant Physiol Biochem 42, 187 195.

DOI: 10.1016/j.plaphy.2004.01.002

Hollman, P.C.H., Slangen, J.H., Wagstaffe, P.J., Faure, U., Southgate, D.A.T. and Finglas, P.M. (1993). Intercomparison of Methods for the Determination of Vitamins in Foods. Part 2. Water-Soluble Vitamins. Analyst 118, 481-488. DOI: 10.1039/AN9931800481

Hothorn, T., Bretz, F. and Westfall, P. (2008). Simultaneous Inference in General Parametric Models. Biom J 50, 346-363. DOI: 10.1002/bimj.200810425

Ihde, A.J. and Schuette, H.A. (1941). Thiamine, Nicotinic Acid, Riboflavin and Pantothenic Acid in Rye and Its Milled Products. J Nutr 22, 527-533. ISSN: 0022-3166

JKI (2018). Julius-Kühn-Institute, Geoportal, http://geoportal.julius-kuehn.de/map?app=oeko. Last Access: 1st of August 2018.

Lebiedzińska, A. and Szefer, P. (2006). Vitamins B in Grain and Cereal-Grain Food, Soy-Products and Seeds. Food Chem 95, 116-122. DOI: 10.1016/j.foodchem.2004.12.024

Lenth, R.V. (2016). Least-Squares Means: The R Package Lsmeans. J Stat Softw 69, 1-33. DOI: 10.18637 jss.v069.i01

McDowell, L.R. (2000). Vitamins in Animal and Human Nutrition, lowa State University Press / Ames. ISBN: 0-8138-2630-6

Michela, P. and Lorenz, K. (1976). The Vitamins of Triticale, Wheat, and Rye. Cereal Chem 53, 853-861.

Nordgren, R. and Andrews, J.S. (1941). The Thiamin Content of Cereal Grains. Cereal Chem 18, 802-811. ISSN: 0009-0352

O'Donnell, W.W. (1943). Effect of Weather, Variety, and Location Upon the Vitamin B1 Content of Some Kansas Grown Wheats. Master's Thesis, Kansas State College of Agriculture and Applied Science. 
Olkowski, B.I. (2008). Riboflavin Content in Lupine Seeds and Blood Plasma Riboflavin Status in Broilers Fed Diets Containing High Levels of Lupine Seeds. J Sci Food Agr 88, 2474-2478. DOI: 10.1002/Jsfa.3365

Peterson, B.G. and Carl, P. (2014). Performanceanalytics: Econometric Tools for Performance and Risk Analysis. R Package Version 1.4.3541.

Piironen, V., Lampi, A.M., Ekholm, P., Salmenkallio-Marttila, M. and Liukkonen, K.H. (2009). Chapter 7: Micronutrients and Phytochemicals in Wheat Grain, Wheat: Chemistry and Technology, American Association of Cereal Chemists International, Inc (AACCI), St Paul (MN), pp. 179-222. DOI: $10.1094 / 9781891127557.007$

R Core Team (2017). R: A Language and Environment for Statistical Computing, Version 3.4.0. http://www.Rproject.org/, R Foundation for Statistical Computing, Vienna, Austria.

Sauvant, D., Perez, J.-M., Tran, G., Bontems, V., Chapoutot, P., Doreau, B., Jeondreville, C., Kaushik, S.J., Lessire, M., Martin-Rosset, W., Meschy, F., Noblet, J., Peyraud, J.-L., Rulquin, H. and Sève, B. (2004). Tables of Composition and Nutritional Value of Feed Materials: Pigs, Poultry, Cattle, Sheep, Goats, Rabbits, Horses and Fish. Wageningen Academic Publishers, INRA, Wageningen \& Paris. ISBN 27380-1158-6

Shewry, P.R., Van Schaik, F., Ravel, C., Charmet, G., Rakszegi, M., Bedo, Z. and Ward, J.L. (2011). Genotype and Environment Effects on the Contents of Vitamins B1, B2, B3, and B6 in Wheat Grain. J Agr Food Chem 59, 10564-10571. DOI: 10.1021/jf202762b

Souci, S.W., Fachmann, W. and Kraut, H. (2008). Food Composition and Nutrition Tables, 7th Edition. MedPharm Scientific Publishers.

USDA (2016). Usda National Nutrient Database for Standard Reference, Release 28, Version Current: September 2015, Slightly Revised May 2016, US Department of Agriculture, Agricultural Research Service, Nutrient Data Laboratory.

Watson, S.A. and Noggle, G.R. (1947). Effect of Mineral Deficiencies Upon the Synthesis of Riboflavin and Ascorbic Acid by the Oat Plant. Plant Physiol 22, 228-243.

Zeileis, A. (2004). Econometric Computing with HC and HAC Covariance Matrix Estimators. J Stat Softw 11, 117. DOI: $10.18637 /$ jss.v011.i10 


\section{Chapter VI}

Exemplary calculations of native thiamine (vitamin $B_{1}$ ) and riboflavin (vitamin $B_{2}$ ) contents in common cereal-based diets for monogastric animals

Beispielkalkulationen von nativen Gehalten an Thiamin (Vitamin $\mathrm{B}_{1}$ ) und Riboflavin (Vitamin $B_{2}$ ) in gewöhnlichen getreidebasierten Rationen für monogastrische Nutztiere

Stephanie Witten, Karen Aulrich Johann Heinrich von Thünen-Institute, Institute of Organic Farming, Trenthorst 32, 23847 Westerau, Germany

Witten, S., Aulrich, K., 2018: Exemplary calculations of native thiamine (vitamin

$B_{1}$ ) and riboflavin (vitamin $B_{2}$ ) contents in common diets for monogastric animals. Org Agric, online first DOI: 10.1007/s13165-018-0219-9

The final publication is available at link.springer.com 


\section{Abstract}

$B$ vitamins, such as thiamine and riboflavin, are often supplemented in diets for farm animals to prevent deficiencies. However, information on the content of these two $B$ vitamins in organic feedstuffs is scarce. Recently, up-to-date information was published by our group. The objective of this work was to use present data to determine the native contents of thiamine and riboflavin in diets used for monogastric animal feeding in organic farming.

We used the results of our recent study on the native thiamine and riboflavin contents of organic wheat (Triticum aestivum L.), rye (Secale cereale L.), triticale (Triticosecale), barley (Hordeum vulgare L.), oats (Avena sativa L.), field peas (Pisum sativum L.), field beans (Vicia faba L.), and blue lupins (Lupinus angustifolius L.) from various variety field trials, which were conducted throughout Germany over three years, to calculate the minimum and maximum native amounts of thiamine and riboflavin in exemplary practical diets for swine and poultry.

We found that exemplary common cereal-based diets in organic farming exceeded the thiamine recommendations for swine and poultry. However, riboflavin was deficient in most exemplary diets. To increase native riboflavin contents in the diet (e. g., for $100 \%$ organic diets), feedstuffs other than cereals and home-grown grain legumes are needed in monogastric animal feeding. In organic farming, roughage plays an important role. The inclusion of grass-clover silage has the potential to increase the native riboflavin contents in the diet. Evaluation of the use of grassland-derived or other products as suppliers of $B$ vitamins, especially for monogastric animal feeding in organic farming, seems promising to improve riboflavin supply.

\section{Keywords}

grain legumes, cereals, swine, poultry 


\section{Zusammenfassung}

B-Vitamine, wie Thiamin und Riboflavin, werden in Rationen für Nutztiere häufig zugesetzt, um Mangelsituationen zu verhindern. Die Mengen, in denen diese B-Vitamine in ökologisch erzeugten Futtermitteln enthalten sind, sind jedoch nicht hinreichend bekannt. Daher war das Ziel dieser Studie, die nativen Gehalte an Thiamin und Riboflavin in Rationen für Monogastrier im Ökologischen Landbau zu ermitteln.

Um die minimalen und maximalen nativen Gehalte an Thiamin und Riboflavin in praktischen Beispielrationen für Schweine und Geflügel zu berechnen, wurden Ergebnisse aus einer Untersuchung zu den nativen Gehalten an Thiamin und Riboflavin in Winterweizen (Triticum aestivum L.), Winterroggen (Secale cereale L.), Wintertriticale (Triticosecale), Wintergerste (Hordeum vulgare L.), Hafer (Avena sativa L.), Futtererbsen (Pisum sativum L.), Ackerbohnen (Vicia faba L.) und blauen Lupinen (Lupinus angustifolius L.) aus ökologischen Sortenversuchen, die in drei Jahren an verschiedenen Standorten in Deutschland durchgeführt wurden, genutzt.

Getreidebasierte Beispielrationen, die in der Praxis im Ökologischen Landbau eingesetzt werden können, hatten sehr hohe native Thiamingehalte, die die aktuellen Empfehlungen für Schweine und Geflügel überschreiten. Jedoch war Riboflavin in den meisten Beispielrationen im Mangel. Um die nativen Riboflavingehalte zu erhöhen (zum Beispiel für eine 100\%-Biofütterung), müssen alternative Futtermittel genutzt werden. Im Ökologischen Landbau spielen Grün- und Raufutter eine wichtige Rolle. Der Einsatz von Kleegrassilage hat das Potential, die nativen Riboflavingehalte in der Ration zu erhöhen. Es wird eine Evaluation von Futtermitteln vom Grünland oder aus Ackerfutterbau sowie von anderen Produkten, die Riboflavin liefern können, empfohlen.

\section{Schlüsselworte}

Vitamin $B_{1}$, Vitamin $B_{2}$, Körnerleguminosen, Getreide, Schweine, Geflügel 


\section{Introduction}

Information on native amounts of thiamine and riboflavin in single feedstuffs and in mixed feed is scarce. New data was provided recently by Witten \& Aulrich (2018). Native thiamine and riboflavin contents were analysed in more than 800 samples of organically cultivated cereals and grain legumes. Consequently, the supply situation for monogastric animals in organic farming should be evaluated on the basis of this new data. It is known that the content of $B$ vitamins in plant feedstuffs can vary depending on genetic and environmental factors (Shewry et al. 2011, Witten \& Aulrich 2018) and can change during storage (Finglas 2003) and processing (Gołda et al. 2004, Lebiedzińska \& Szefer 2006). Cereal-based diets are suspected to contain low amounts of riboflavin but sufficient amounts of thiamine (GFE 2006, Jeroch et al. 2008). Nevertheless, since B vitamins are important coenzymes (Depeint et al. 2006, Fattal-Valevski 2011) and their deficiencies can cause severe health and performance problems (Blair \& Newsome 1985). Thus, even in organic farming, both B vitamins are regularly supplemented in mixed feed in amounts that cover animal requirements with an additional safety margin. Knowledge of the amounts of native thiamine and riboflavin in organic diets can help to assess the additional need for these vitamins. This need can be addressed in diet formulation and covered using feedstuffs with high amounts of thiamine and/or riboflavin or supplements.

B vitamins for supplements can be produced using chemical synthesis (McDowell 2000, Albers et al. 2002) or fermentation (Burgess et al. 2009, Capozzi et al. 2012). While thiamine is generally chemically synthesised (Revuelta et al. 2016), the use of fermentation in producing riboflavin has replaced the use of chemical synthesis in the last decades (Schwechheimer et al. 2016, Revuelta et al. 2017). Microorganisms used for the fermentation of vitamins are often genetically modified organisms (GMOs). However, GMOs, as well as their products, are banned in organic farming (EC 2007, 2008). Thus, feedstuffs must provide sufficient amounts of B vitamins without GMO-based supplements. Pasture and roughage are encouraged to be used in organic farming and are assumed to have the potential to enhance the supply of B vitamins. Depending on temperature, age, and performance, diets for pigs and poultry can contain $6-20 \%$ of grassland-derived silage (Edwards 2003, Crawley 2015b, a). Thus, the potential of grassland-derived feedstuffs as GMO-free suppliers of B vitamins for monogastric animals is of interest, especially in organic farming.

The objective of this study was to determine how variations of thiamine and riboflavin contents in cereals and grain legumes affect the total thiamine and riboflavin content in diets for monogastric animals. We also aimed to determine the gap between the recommended and the actual native supply of thiamine and riboflavin for monogastric animals in organic 
farming as well as the potential of grass-clover silage as a supplier of riboflavin. Among other things, this knowledge is necessary to support $100 \%$ organic feeding.

\section{Materials and Methods}

Data on thiamine and riboflavin contents in cereals and grain legumes from an earlier study (Witten \& Aulrich 2018) were used to calculate native thiamine and riboflavin contents in organic diets for monogastric animals. Additionally, three samples of organically produced grass-red clover silage, which was harvested in May 2016 (first cut) and is used for swine feeding on our experimental farm in northern Germany, were additionally taken out of round bales, freeze-dried and analysed for their amounts of riboflavin.

Exemplary cereal-based organic diets for swine and poultry in Germany were selected from articles and reports. For further evaluation, we chose diets for sows, growing pigs, and fattening pigs (Table VI 1), as well as for poultry of different use (Table VI 2), which contained

- a minimum proportion of $70 \%$ (with exceptions for growing pigs and broiler chicken) of cereals and grain legumes for which samples had been analysed (Witten and Aulrich 2018; winter wheat (Triticum aestivum L.), winter rye (Secale cereale L.), winter triticale (Triticosecale), winter barley (Hordeum vulgare L.), oats (Avena sativa L.), field peas (Pisum sativum L.), field beans (Vicia faba L.), and blue lupins (Lupinus angustifolius L.) from various variety field trials, which were conducted throughout Germany over three years), and

- additional feedstuffs, for which thiamine and riboflavin contents were available in the feed composition tables of Sauvant et al. (2004).

Subsequently, the minimum and maximum of our analysis results for thiamine and riboflavin contents were used to calculate the minimum and maximum amounts of thiamine and riboflavin originating from cereals and grain legumes in the diets. The amounts of thiamine and riboflavin originating from other feedstuffs were estimated using the table values published by Sauvant et al. (2004). The sum of both values equals the total content of thiamine and riboflavin, respectively, in the diets.

Furthermore, we tested the effect of an inclusion of $10 \%$ grass-red clover silage in the dry matter (DM) of each diet on the riboflavin content. All other feedstuffs were reduced simultaneously. 


\begin{tabular}{|c|c|c|c|}
\hline \multicolumn{2}{|c|}{ ৯ } & \multicolumn{2}{|c|}{ 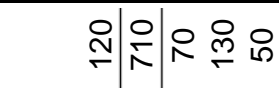 } \\
\hline$\stackrel{\infty}{\sim}$ & 号 & 응워 & 요 \\
\hline$\stackrel{\leftrightarrow}{\sim}$ & 용 & 웜 & \\
\hline 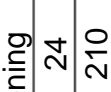 & 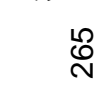 & 응요 윤 & \\
\hline 离| & 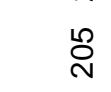 & & 요 \\
\hline$\approx$ 总 & $\stackrel{\mathscr{\vartheta}}{\mathscr{\gamma}}$ & : & in \\
\hline $\bar{N}$ & 유 ఖ్ & 怘 & \\
\hline ని & ৪্ল & ঃ요 & \\
\hline
\end{tabular}

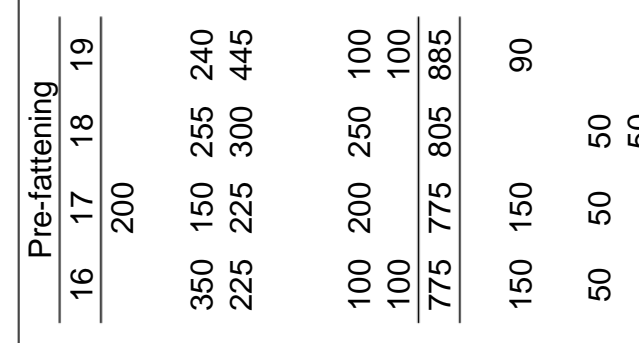

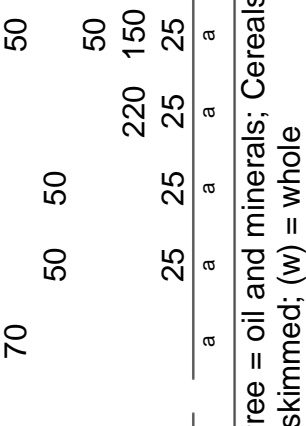

ล ลิ०

นึ)

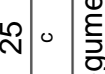

ㅇ.

ก $\approx$

ก.

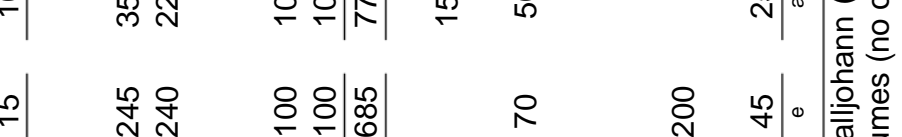

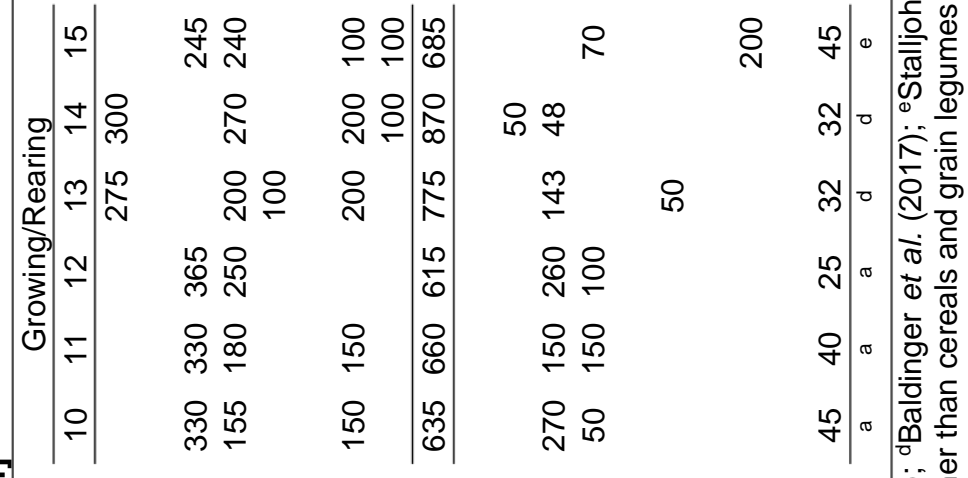

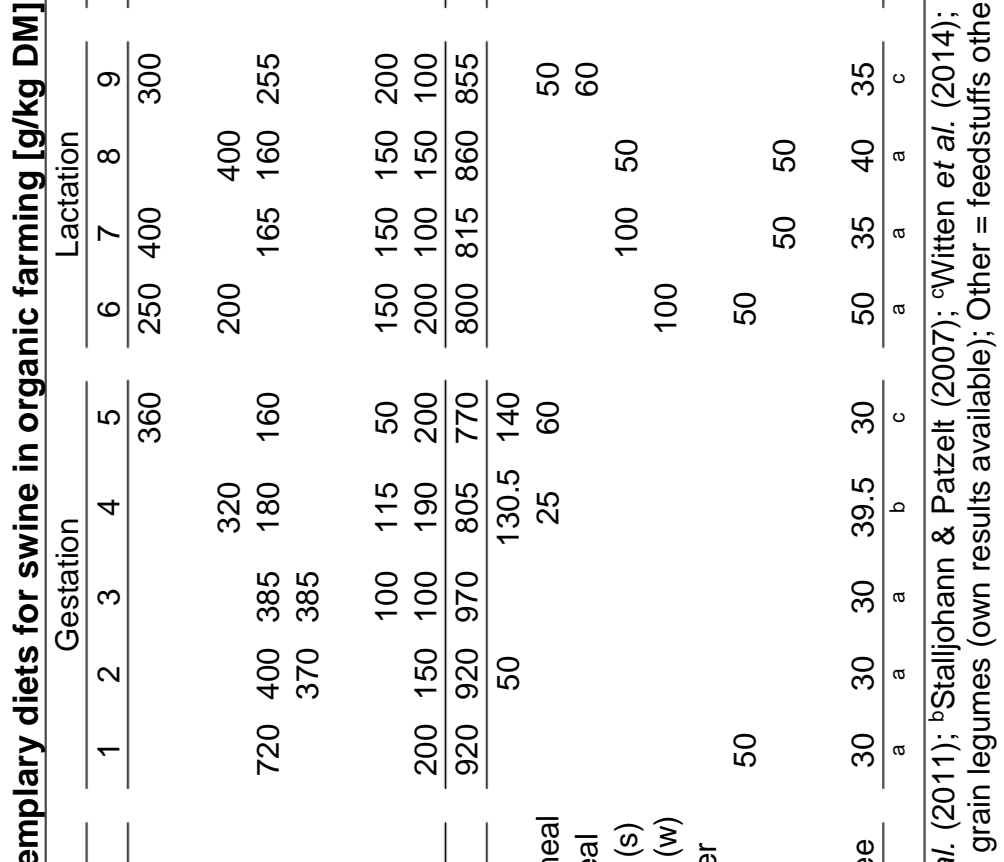

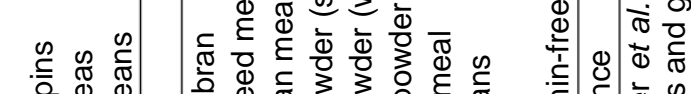

芝 
Table VI 2: Exemplary diets for poultry in organic farming [g/kg DM]

\begin{tabular}{|c|c|c|c|c|c|c|c|c|c|}
\hline & & Starter & & & ing $\mathrm{H}$ & & & & \\
\hline & Diet & 1 & 2 & 3 & 4 & 5 & 6 & 7 & 8 \\
\hline & Triticale & & & 300 & 200 & 300 & 300 & & \\
\hline$\stackrel{\mathscr{E}}{\varepsilon}$ & Rye & & & & 200 & & 200 & & \\
\hline 莺 & Wheat & 460 & 350 & 350 & & & & 350 & 200 \\
\hline త) & Barley & & 50 & & & 100 & & 100 & 200 \\
\hline$\vec{\infty}$ & Oats & & 100 & & & 200 & & 100 & 103 \\
\hline$\infty$ & Blue lupin & & & & 200 & & 200 & & \\
\hline$\underset{ల}{\mathscr{D}}$ & Field peas & 200 & 150 & 200 & & 150 & & 70 & 120 \\
\hline ঠ) & Field beans & 80 & 60 & & 50 & & & 150 & \\
\hline & Grass-clover-silage & & & 50 & 50 & 50 & 50 & & \\
\hline & Sum & 740 & 710 & 900 & 700 & 800 & 750 & 770 & 623 \\
\hline & Corn & & & & 190 & 100 & 180 & & 180 \\
\hline & Linseed & & & & 10 & & & & \\
\hline & Soybean meal & & & 100 & & 100 & 50 & & 100 \\
\hline & Sunflower meal & & & & & & & & 30 \\
\hline ఫे & Linseed meal & & & & & & 20 & & 30 \\
\hline 点 & Maize gluten & 170 & 120 & & & & & 100 & \\
\hline & Brewer's yeast & 20 & 20 & & & & & 30 & \\
\hline & Green meal & & 30 & & & & & 50 & \\
\hline & Maize gluten feed & & & & 100 & & & & \\
\hline & B vitamin-free & 70 & 120 & & & & & 50 & 37 \\
\hline & Reference & $\mathrm{a}$ & a & $\mathrm{b}$ & b & $\mathrm{b}$ & b & a & 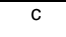 \\
\hline
\end{tabular}

aDeerberg (2000); bSteinhöfel \& Lippmann (2005); 'Bellof et al. (2005); B vitamin-free = oil and minerals; Cereals \& Legumes = cereals and legumes (own results available); Other = feedstuffs other than cereals and grain legumes (no own results)

We compared thiamine and riboflavin recommendations (NRC 1994, GfE 1999, GfE 2006, NRC 2012) with thiamine and riboflavin contents in all exemplary diets for swine and poultry.

\section{Results}

The contents of both B vitamins varied widely in our sample set (Table VI 3).

Table VI 3: Contents of thiamine and riboflavin in different cereals and legumes [mg/kg DM]

\begin{tabular}{lccc}
\hline & $\mathrm{n}$ & Thiamine & Riboflavin \\
\hline Cereals & & & \\
$\quad$ Winter wheat (Triticum aestivum L.) & 106 & $1.61-2.96$ & $0.62-0.89$ \\
Winter rye (Secale cereale L.) & 106 & $1.16-2.35$ & $0.84-1.28$ \\
Winter triticale (Triticosecale) & 107 & $1.27-2.38$ & $0.65-1.17$ \\
Winter barley (Hordeum vulgare L.) & 30 & $1.76-3.01$ & $0.65-1.06$ \\
Oats (Avena sativa L.) & 105 & $1.87-3.53$ & $0.71-1.54$ \\
\hline Legumes & & & \\
Spring field pea (Pisum sativum L.) & 87 & $2.66-9.56$ & $1.00-2.28$ \\
Spring field bean (Vicia faba L.) & $73 / 82^{*}$ & $2.55-7.37$ & $2.13-3.84$ \\
Blue lupin (Lupinus angustifolius L.) & 110 & $2.81-8.97$ & $1.94-3.05$ \\
Grass-red clover silage & 3 & & $5.37-7.61$ \\
\hline
\end{tabular}

*thiamine/riboflavin; adapted from Witten \& Aulrich (2018) 


\section{Diets for swine}

The total thiamine content in all exemplary diets for swine exceeded the recommendations of GfE (2006) and NRC (2012). The amount of thiamine originating from cereals and grain legumes without considering thiamine in additional feedstuffs met the NRC (2012) recommendations in all diets for sows (Table VI 4) and fattening pigs (Table VI 5), as well as in five out of six diets for growing pigs (Table VI 4) weighing more than $5 \mathrm{~kg}$ and even GfE (2006) recommendations could be met.

The riboflavin recommendations for sows and fattening pigs of GfE (2006) and NRC (2012) are comparable. However, for growing pigs weighing more than $10 \mathrm{~kg}$, NRC (2012) recommends lower amounts of riboflavin, which decrease with increasing age/weight. Due to high required amounts, no diet for gestating and lactating sows could meet the official recommendations for riboflavin (GfE 2006, NRC 2012). However, in diets 6 and 7 for lactating sows, the inclusion of $100 \mathrm{~g}$ milk powder and either $50 \mathrm{~g}$ green meal or soybeans per $\mathrm{kg}$ DM led to considerably higher riboflavin contents than in the other diets for sows. Diets $10,12,13$, and 14 for growing pigs, diets 16, 17, and 19 for pre-fattening pigs, and diets 23,25 , and 26 for fattening pigs, which only contained oilseed meals as additional feedstuffs, were also not able to cover the recommendations. While $50 \mathrm{~g}$ green meal and $20 \mathrm{~g}$ soybeans contained just enough riboflavin to possibly lead to sufficient amounts in diets 22 and 27 for fattening pigs, diets 11 and 15 for growing pigs, diet 18 for pre-fattening pigs, and diets 20,21 , and 24 for fattening pigs covered the official recommendations of both GfE (2006) and NRC (2012). Those diets contained milk products, green meal, and/or soybeans. Only diet 14 for growing pigs could not meet the minimum recommendation of NRC (2012).

A replacement of a part of the diet with grass-clover silage increased its riboflavin supply. When $10 \%$ grass-clover silage were included, diets 6 and 7 for lactating sows, diet 12 for growing pigs weighing more than $10 \mathrm{~kg}$, diet 16 and 17 for pre-fattening pigs, as well as diets 23 and 25 for fattening pigs could cover the riboflavin recommendations of GfE (2006), when single feedstuffs with high native riboflavin contents were used. 


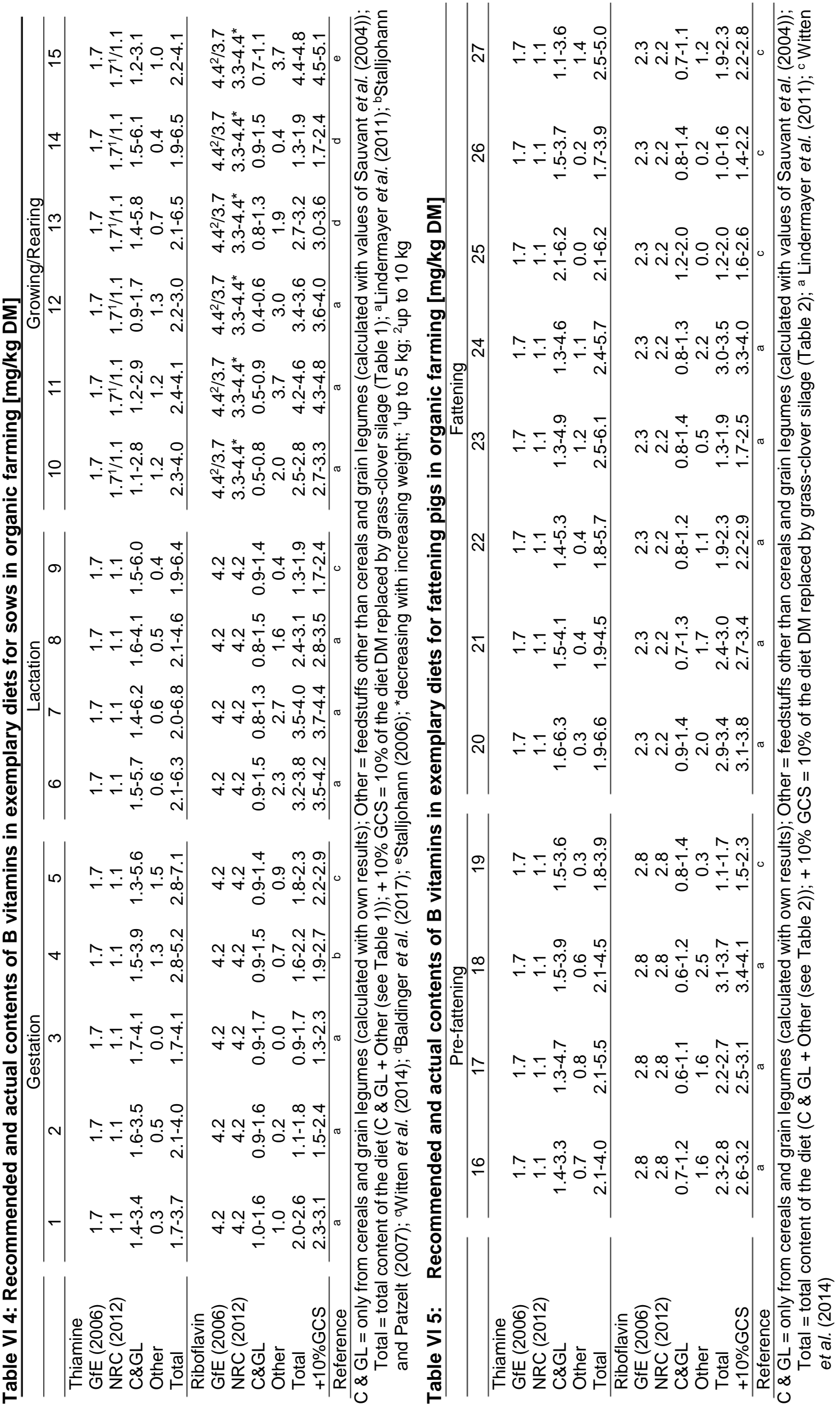




\section{Diets for poultry}

Recommendations for the supply of thiamine in poultry diets vary, with GfE recommendations being higher than those of the NRC. While all poultry diets met the NRC recommendations, the minimum thiamine content of diet 8 for broilers did not meet GfE recommendations when only single feedstuffs with minimum amounts of thiamine were used (Table VI 6).

Like in diets for swine, riboflavin was often deficient in poultry diets. GfE (1999) and NRC (1994) recommend similar amounts of riboflavin. Only diet 7 for broiler chicken and diet 2 for laying hens, which contained brewer's yeast and green meal, provided the recommended amount of riboflavin when the riboflavin content of the single feedstuffs was high. The other diets contained mostly corn and oilseed meals in addition to cereals and grain legumes.

The inclusion of grass-clover silage led to an increased total amount of riboflavin in all diets. However, most of the diets still did not meet the recommended amount of riboflavin.

Table VI 6: Recommended and actual contents of B vitamins in exemplary diets for poultry in organic farming [mg/kg DM]

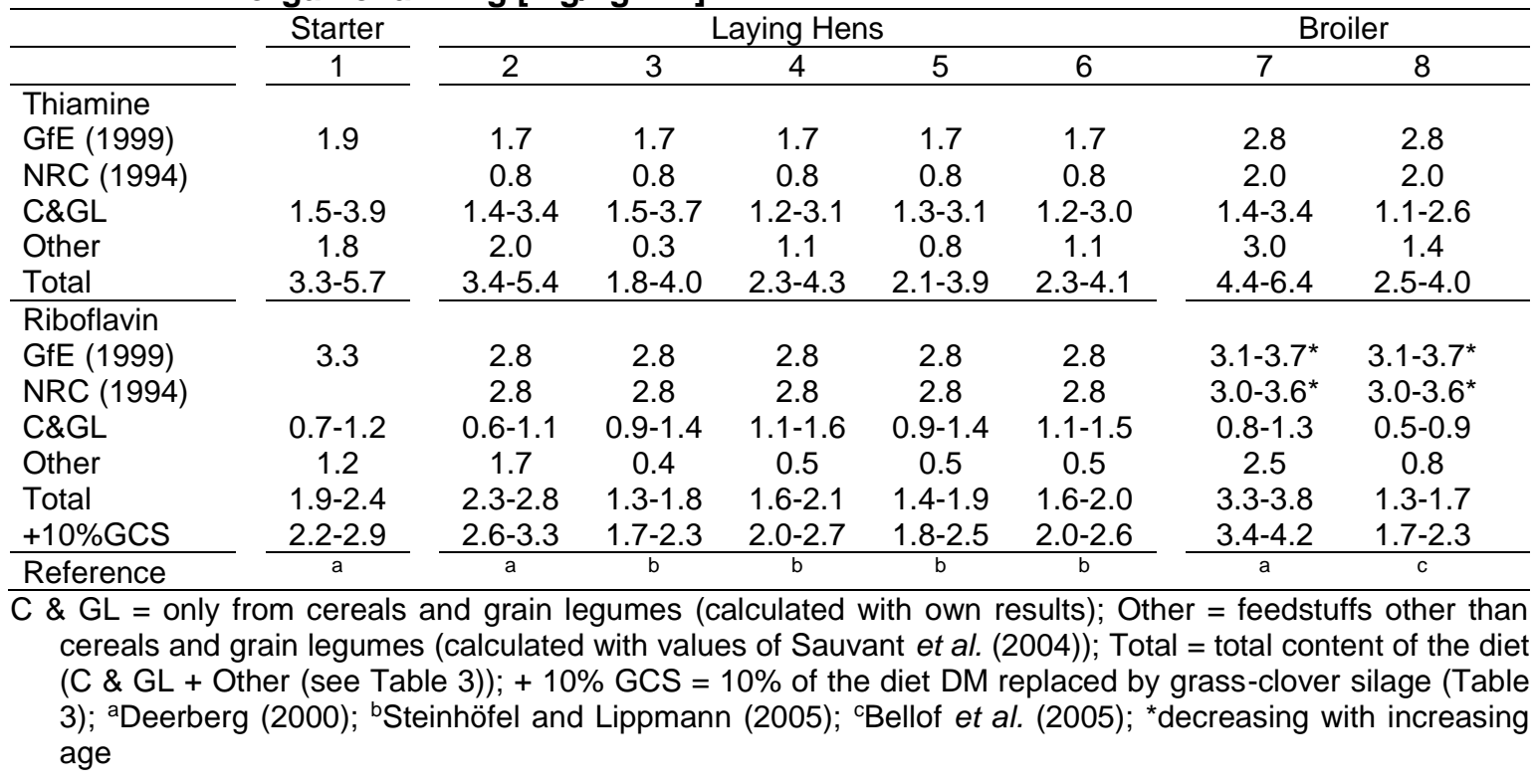

\section{Discussion}

Recommendations for the supply of thiamine and riboflavin are ambiguous, and research in this field is encouraged. There have been only a few investigations on this subject and most were conducted decades ago (GfE 2006, McDowell \& Ward 2008, de Lange 2013). More recent investigations tend to recommend higher amounts of thiamine and riboflavin for poultry (summarised in Jeroch et al. 2011, Jeroch et al. 2012). Furthermore, requirements depend on the performance of the animal. In organic farming, animal husbandry is normally less intensive (Hovi et al. 2003), and especially for poultry, strains with less rapid growth are often used (Blair 2008). Husbandry systems including pasture 
and outdoor areas affect animal performance and energy needs (Edwards 2003). Since thiamine and riboflavin are needed in energy metabolism, the dietary B vitamin needs of monogastric animals in organic farming could also be affected. For example, the environmental temperature can affect the daily weight gain and feed intake and consequently also the thiamine requirements of pigs (Peng \& Heitman 1974). However, although knowing that further investigations and possibly revisions are needed, we used official German and American recommendations to determine if the native thiamine and riboflavin content of the mixed feed would be sufficient for swine and chicken.

\section{Thiamine}

Since our results suggest that the supply of native thiamine in cereal-based diets for monogastric animals in organic farming is usually sufficient, thiamine supplementation for organic cereal-based diets does not seem necessary. However, supplementation might be required, when thiamine availability is poor. Thiamine can be inhibited by antagonists or destroyed due to heat (McDowell \& Ward 2008). Thus, heat treatment and pelleting can reduce its availability.

\section{Riboflavin}

Skinner et al. (1992) fed a diet based on corn and soybean meal with $50 \mathrm{~g} / \mathrm{kg}$ fish meal analogue as a protein source without $B$ vitamin supplementation to broilers and found no effect on health or performance. However, this dietary composition is hardly comparable to common European cereal-based diets. In most of our cereal-based diets, the amounts of riboflavin were lower than recommended. Only an inclusion of other feedstuffs could possibly lead to a sufficient supply. It should also be considered that riboflavin is not stable under the exposure to light McDowell \& Ward (2008) and its availability must be taken into account. Cereal-based diets in organic farming should, therefore, contain specific feedstuffs with high amounts of riboflavin (Oehen et al. 2011). In the absence of our own analysis results for those feedstuffs, we used table values to calculate the total content of thiamine and riboflavin in the exemplary diets. However, those values cannot display the variability of the composition. Soybeans supposedly contain about $11 \mathrm{mg}$ riboflavin/kg DM (Sauvant et al. 2004). They might, therefore, contribute to the supply of riboflavin. Yet, since we found wide variations of the riboflavin content in home-grown grain legumes, it is quite possible that there are also wide variations of the riboflavin content in soybeans. Milk products contain high amounts of riboflavin (Marconi \& Panfili 1998, USDA 2016). Whey powder or milk powder are often used in diets for piglets and lactating sows but are not as common in diets for other adult pigs or for poultry. Brewer's yeast is known to contain high amounts of $B$ vitamins, including thiamine with $91 \mathrm{mg} / \mathrm{kg}$ DM and riboflavin with $43 \mathrm{mg} / \mathrm{kg}$ DM (Sauvant et al. 2004), and other favourable components (Yamada \& Sgarbieri 2005). Thus, the inclusion of small amounts of brewer's yeast strongly increased B vitamin supply of our 
exemplary diets. Provided that brewer's yeast can be obtained for feed production, its use can be recommended.

Grassland-derived products like green meals from grass, alfalfa, and/or clover can also improve riboflavin supply. However, data on the contents are scarce. Moreover, roughage and pasture, which are already used in organic farming (Crawley 2015b, a), can contribute to the supply of B vitamins. Grass-clover silage has proved to be promising to increase the supply of riboflavin. In our study, we included $10 \%$ grass-clover silage in the diets. It can be assumed that pigs would take up even more silage on top of their normal feed intake (Carlson et al. 1999).

In addition to the use of those feedstuffs, it might be possible to improve the riboflavin content of cereals and grain legumes. Since germination of grains from cereals and legumes is known to increase riboflavin contents (Prodanov et al. 1997, Sierra \& VidalValverde 1999, Flamme et al. 2003), germination of those grains might also help to close the gap in riboflavin supply. However, further investigations on this topic would help to evaluate the benefit.

\section{Conclusions}

Variations of thiamine and riboflavin in single feedstuffs strongly affect their contents in exemplary diets for monogastric animals. Average cereal-based diets mostly exceed the thiamine requirements of monogastric farm animals. Thus, no gap between the recommended and the actual native supply was observed. It should be noted, however, that thiamine availability could not be taken into account. The amount of riboflavin, on the other hand, was found to be insufficient in most of our exemplary diets. Therefore, supplementation is recommended. The extent of the deficiency depends on the amount of cereals and grain legumes in the diet, animal performance, and the recommendations used. In our example, the extent of the deficiency is the highest for gestating sows with up to 3.3 $\mathrm{mg}$ riboflavin/kg DM in a diet consisting only of cereals and home-grown grain legumes and for broiler chicken with up to $2.4 \mathrm{mg} / \mathrm{kg}$ DM. The addition of alternative feedstuffs to meet riboflavin requirements in monogastric animal feeding can reduce the need for supplementation and, therefore, contribute to $100 \%$ organic feeding. Further research on products derived from grassland or other alternative products, like germinated seeds, as suppliers of riboflavin is needed. Moreover, thiamine and riboflavin recommendations should be verified under the consideration of advances in animal production for conventional and organic farming. 


\section{References}

Albers, N., Gotterbarm, G., Heimbeck, W., Keller, T., Seehawer, J. and Tran, T.D. (2002). Vitamins in Animal Nutrition. AWT (Ed.), ERLING Verlag GmbH \& Co. KG, Clenze, Germany. ISBN: 3-86037-167-3

Baldinger, L., Bussemas, R., Höinghaus, K., Renger, A. and Weißmann, F. (2017). Effect of Six $100 \%$ Organic Feeding Strategies Differing in External Input Demand on Animal Performance and Production Costs of Piglets before and after Weaning. Org Agr 7, 267-279. DOI: 10.1007/s13165-016-0157-3

Bellof, G., Schmidt, E. and Ristic, M. (2005). Einfluss abgestufter Aminosäuren-Energie-Verhältnisse im Futter auf die Mastleistung und den Schlachtkörperwert einer langsam wachsenden Herkunft in der Ökologischen Broilermast [Effect of Graded Essential Amino Acids to Energy Ratios in Diets for Organic Chicken Production on Fattening Performance and Carcass Yield]. Arch Geflugelkd 69, 252260. ISSN: 0003-9098

Blair, R. (2008). Nutrition and Feeding of Organic Poultry. CABI. ISBN: 9781845934064

Blair, R. and Newsome, F. (1985). Involvement of Water-Soluble Vitamins in Diseases of Swine. Anim Sci 60, 1508-1517. DOI: $10.2527 /$ jas1985.6061508x

Burgess, C.M., Smid, E.J. and van Sinderen, D. (2009). Bacterial Vitamin B2, B11 and B12 Overproduction: An Overview. Int J Food Microbiol 133, 1-7. DOI: 10.1016/j.jjfoodmicro.2009.04.012

Capozzi, V., Russo, P., Dueñas, M.T., López, P. and Spano, G. (2012). Lactic Acid Bacteria Producing B-Group Vitamins: A Great Potential for Functional Cereals Products. Appl Microbiol Biot 96, 1383-1394. DOI: $10.1007 / \mathrm{s} 00253-012-4440-2$

Carlson, D., Lærke, H.N., Poulsen, H.D. and Jørgensen, H. (1999). Roughages for Growing Pigs, with Emphasis on Chemical Composition, Ingestion and Faecal Digestibility. Acta Agric Scan, Sect A - Anim Sci 49, 129-136. DOI: 10.1080/090647099424033

Crawley, K. (2015a). Fulfilling 100\% Organic Pig Diets: Roughage and Foraging from the Range, In: Smith, J., Gerrard, C.L. and Sumption, P. (Eds.), ICOPP Technical Note, Organic Research Center UK.

Crawley, K. (2015b). Fulfilling 100\% Organic Poultry Diets: Roughage and Foraging from the Range, In: Smith, J., Gerrard, C.L. and Sumption, P. (Eds.), ICOPP Technical Note, Organic Research Center UK.

de Lange, C.F. (2013). New Nrc (2012) Nutrient Requirements of Swine. Advances in Pork Production 24, 17 28.

Deerberg, F. (2000). Geflügelfütterung Im Ökologischen Landbau [Poultry Feeding in Organic Farming]. GäaJournal 4.

Depeint, F., Bruce, W.R., Shangari, N., Mehta, R. and O'Brien, P.J. (2006). Mitochondrial Function and Toxicity: Role of the B Vitamin Family on Mitochondrial Energy Metabolism. Chem Biol Interact 163, 94-112. DOI: 10.1016/j.cbi.2006.04.014

EC (2007). Council Regulation (EC) No 834/2007 of 28 June 2007 on Organic Production and Labelling of Organic Products and Repealing Regulation (EEC) No 2092/91.

EC (2008). Commission Regulation (EC) No 889/2008 of 5 September 2008 Laying Down Detailed Rules for the Implementation of Council Regulation (EC) No 834/2007 on Organic Production and Labelling of Organic Products with Regard to Organic Production, Labelling and Control.

Edwards, S.A. (2003). Intake of Nutrients from Pasture by Pigs. Proc Nutr Soc 62, 257-265. DOI: 10.1079/PNS2002199

Fattal-Valevski, A. (2011). Thiamine (Vitamin B1). J Evid Based Complementary Altern Med 16, 12-20. DOI: $10.1177 / 1533210110392941$

Finglas, P.M. (2003). Vitamins, In: Caballero, B., Finglas, P. M., Trugo, L. C. (Ed.), Encyclopedia of Food Sciences and Nutrition, pp. 6046-6053. ISBN: 978-0-12-227055-0

Flamme, W., Kurpjun, C., Seddig, S., Jansen, G. and Jürgens, H.-U. (2003). Gekeimte Samen als Futtermittel - Analytik [Germinated Seeds as Feedstuffs - Analytics], Julius Kühn-Institute (JKI), Sanitz, Germany.

GfE (1999). Empfehlungen zur Energie- und Nährstoffversorgung der Legehennen und Masthühner (Broiler) [Recommendations for the Energy and Nutrient Supply for Layers and Broilers]. DLG Verlag, Frankfurt a. M., Germany.

GfE (2006). Empfehlungen zur Energie- und Nährstoffversorgung von Schweinen [Recommendations for the Energy and Nutrient Supply for Swine]. DLG Verlag, Frankfurt a. M., Germany.

Gołda, A., Szyniarowski, P., Ostrowska, K., Kozik, A. and Rapała-Kozik, M. (2004). Thiamine Binding and Metabolism in Germinating Seeds of Selected Cereals and Legumes. Plant Physiol Biochem 42, 187195. DOI: 10.1016/j.plaphy.2004.01.002

Hovi, M., Sundrum, A. and Thamsborg, S.M. (2003). Animal Health and Welfare in Organic Livestock Production in Europe: Current State and Future Challenges. Livest Prod Sci 80, 41-53. DOI: 10.1016/S0301-6226(02)00320-2 
Jeroch, H., Drochner, W. and Simon, O. (2008). Ernährung landwirtschaftlicher Nutztiere [Nutrition of Farm Animals]. Eugen Ulmer KG, Stuttgart, Germany. ISBN: 978-3-8252-8180-9

Jeroch, H., Kozlowski, K. and Jankowski, J. (2011). Versorgung des Geflügels mit Energie und Nährstoffen aus der Sicht nationaler und internationaler Empfehlungen [National and International Recommendations for the Energy and Nutrient Supply of Poultry]. Arch Geflugelk 75, 217-225. ISSN: 0003-9098

Jeroch, H., Simon, A. and Zentek, J. (2012). Geflügelernährung [Poultry Nutrition]. Ulmer. ISBN: 978-3-8001-7869-8

Lebiedzińska, A. and Szefer, P. (2006). Vitamins B in Grain and Cereal-Grain Food, Soy-Products and Seeds. Food Chem 95, 116-122. DOI: 10.1016/j.foodchem.2004.12.024

Lindermayer, H., Probstmeier, G., Preißinger, W. and Pieringer, E. (2011). Fütterungsfibel Ökologische Schweinehaltung [Handbook for Organic Pig Feeding], 3rd Edition, Bavarian State Research Institute for Agriculture (LfL), Freising.

Marconi, E. and Panfili, G. (1998). Chemical Composition and Nutritional Properties of Commercial Products of Mare Milk Powder. J Food Comp Anal 11, 178-187. DOI: 10.1006/jfca.1998.0573

McDowell, L.R. (2000). Vitamins in Animal and Human Nutrition, lowa State University Press / Ames. ISBN: 08138-2630-6

McDowell, L.R. and Ward, N.E. (2008). Optimum Vitamin Nutrition for Poultry. Intern Poult Prod 16, 27-34.

NRC (1994). (National Research Council) Nutrient Requirements of Poultry, 9th Revised Edition, In: Nutrition, S.o.P., Nutrition, C.o.A. and Council, N.R. (Eds.), National Academie Press, Washington DC, Washington D.C.

NRC (2012). (National Research Council) Nutrient Requirements of Swine, 11th Revised Edition. The National Academies Press, Washington DC. ISBN: 9780309059930

Oehen, B., Früh, B. and Schneider, C. (2011). Alternatives for the Substitution of Synthetic Vitamin B2 or Vitamin B2 Produced from Gmos. Research Institute of Organic Agriculture (Fibl), Ch Frick.

Peng, C.L. and Heitman, H. (1974). The Effect of Ambient Temperature on the Thiamin Requirement of GrowingFinishing Pigs. Br J Nutr 32, 1-9. DOI: 10.1079/BJN19740053

Prodanov, M., Sierra, I. and Vidal-Valverde, C. (1997). Effect of Germination on the Thiamine, Riboflavin and Niacin Contents in Legumes. Z Lebensm Unters F A 205, 48 - 52. DOI: 10.1007/s002170050122

Revuelta, J.L., Buey, R.M., Ledesma-Amaro, R. and Vandamme, E.J. (2016). Microbial Biotechnology for the Synthesis of (Pro)Vitamins, Biopigments and Antioxidants: Challenges and Opportunities. Microb Biotechnol 9, 564-567. DOI: 10.1111/1751-7915.12379

Revuelta, J.L., Ledesma-Amaro, R., Lozano-Martinez, P., Díaz-Fernández, D., Buey, R.M. and Jiménez, A. (2017). Bioproduction of Riboflavin: A Bright Yellow History. J Ind Microbiol Biot 44, 659-665. DOI: $10.1007 / \mathrm{s} 10295-016-1842-7$

Sauvant, D., Perez, J.-M., Tran, G., Bontems, V., Chapoutot, P., Doreau, B., Jeondreville, C., Kaushik, S.J., Lessire, M., Martin-Rosset, W., Meschy, F., Noblet, J., Peyraud, J.-L., Rulquin, H. and Sève, B. (2004). Tables of Composition and Nutritional Value of Feed Materials: Pigs, Poultry, Cattle, Sheep, Goats, Rabbits, Horses and Fish. Wageningen Academic Publishers, INRA, Wageningen \& Paris. ISBN 2-7380-1158-6

Schwechheimer, S.K., Park, E.Y., Revuelta, J.L., Becker, J. and Wittmann, C. (2016). Biotechnology of Riboflavin. Appl Microbiol Biot 100, 2107-2119. DOI: 10.1007/s00253-015-7256-Z

Shewry, P.R., Van Schaik, F., Ravel, C., Charmet, G., Rakszegi, M., Bedo, Z. and Ward, J.L. (2011). Genotype and Environment Effects on the Contents of Vitamins B1, B2, B3, and B6 in Wheat Grain. J Agr Food Chem 59, 10564-10571. DOI: 10.1021/jf202762b

Sierra, I. and Vidal-Valverde, C. (1999). Kinetics of Free and Glycosylated B6 Vitaminers, Thiamin and Riboflavin During Germination of Pea Seeds. J Sci Food Agric 79, 307-310. DOI: 10.1002/(sici)1097-0010(199902)79:2<307::Aid-jsfa195>3.0.Co;2-z

Skinner, J.T., Waldroup, A.L. and Waldroup, P.W. (1992). Effects of Removal of Vitamin and Trace Mineral Supplements from Grower and Finisher Diets on Live Performance and Carcass Composition of Broilers. J Appl Poult Res 1, 280-286. DOI: 10.1093/japr/1.3.280

Stalljohann, G. (2006). Untersuchungen Zu Fütterungsstrategien Für Eine Erfolgreiche Aufzucht Ökologisch Gehaltener Ferkel [Analysing Feeding Strategies for a Successful Rearing of Ecologically Fed Piglets]. Dissertation, Ludwig-Maximilians-University Munich.

Stalljohann, G. and Patzelt, S. (2007). Report: Vorläufige Versuchsergebnisse Bei 100 \% Öko-Ferkelfütterung Im Landwirtschaftszentrum (LZ) Haus Düsse [Preliminary Results of a Trial Regarding $100 \%$ Organic Feeding for Piglets], LWK NRW, Landwirtschaftszentrum (LZ) Haus Düsse. 
Steinhöfel, O. and Lippmann, I. (2005). Futterrationsbeispiele für Ökobetriebe [Exemplary Diets for Organic Farms], Sächsische Landesanstalt für Landwirtschaft (LfL),

https://www.landwirtschaft.sachsen.de/landwirtschaft/download/Futterrationsbeispiele_Oeko.pdf, Last Access 30th of January 2018.

USDA (2016). USDA National Nutrient Database for Standard Reference, Release 28, Version Current: September 2015, Slightly Revised May 2016, US Department of Agriculture, Agricultural Research Service, Nutrient Data Laboratory.

Witten, S. and Aulrich, K. (2018). Effect of Variety and Environment on the Amount of Thiamine and Riboflavin in Cereals and Grain Legumes. Anim Feed Sci Tech 238, 39-46. DOI: 10.1016/j.anifeedsci.2018.01.022

Witten, S., Paulsen, H.-M., Weißmann, F. and Bussemas, R. (2014). Praxisbefragung zur Aminosäurelücke und praktische Möglichkeiten zur Verbesserung der Eiweißversorgung der Monogastrier in der Fütterung im Ökologischen Landbau [Survey on Practice of the Use and Availability of Protein Sources to Close Amino Acid Gaps in Feeding Monogastric Animals in Organic Farming]. Thünen Working Paper 23.

Yamada, E.A. and Sgarbieri, V.C. (2005). Yeast (Saccharomyces Cerevisiae) Protein Concentrate: Preparation, Chemical Composition, and Nutritional and Functional Properties. J Agr Food Chem 53, 3931-3936. DOI: $10.1021 / \mathrm{jf0400821}$ 


\section{General Discussion}

The optimisation of diets for farm animals contributes to the improvement of their health and performance and also allows to use resources more effectively (Le Bellego \& Noblet 2002). However, the nutrient composition of single feedstuffs must be known to formulate optimal diets that prevent nutrient deficiencies and also enhance the efficiency of nutrient utilisation due to the adjustment of their composition. Thus, the sample set of the present study was used to give an overview of the nutrient composition of organic cereals and grain legumes from across Germany. Organic farming aims for $100 \%$ organic feeding. Thus, the needs of animals should be met with the native nutrient contents of the feedstuffs. This makes the results of the characterisation of commonly used feedstuffs on the basis of their nutrient composition very important.

In addition, protein evaluation can contribute to a more efficient and sustainable animal feeding. An adjustment of the AA supply allows to reduce the CP concentrations in the diet and, therefore, preserves the environment and relieve the animal metabolism due to lower nitrogen loads. Due to the AA gap being a major concern in organic farming, the focus is often laid on protein evaluation. Furthermore, to describe the quality of a feed protein, the amount of bioavailable AA contained in the feedstuff is of interest (Kong \& Adeola 2014). For practical feeding, CP and AA digestibility coefficients are used to estimate the amount of potentially bioavailable CP and AA (Stein et al. 2007, Fuller 2012), although the metabolic availability of $\mathrm{CP}$ and $\mathrm{AA}$ is not only determined by their digestibility but, for example, also by factors limiting their absorption. However, for diet formulation, the $\mathrm{CP}$ and $\mathrm{AA}$ digestibility, which benefits from its additivity (Angkanaporn et al. 1996, Stein et al. 2005), is a good approximation.

Nutrient digestibility can be determined in vivo. However, the in vivo determination of the $\mathrm{CP}$ and $\mathrm{AA}$ digestibility is costly, time-consuming, and problematic regarding animal welfare. Since the digestibility and the availability of $C P$ and $A A$ can vary widely within and among feedstuffs (Jezierny et al. 2011), the use of an in vitro assay to rapidly and accurately predict the CP and AA digestibility is desirable. However, the quality of the results derived from the underlying in vivo studies is a determinant for the quality of an in vitro assay.

In the present study, the prediction of the precaecal $(\mathrm{pc})$ digestibility was preferred to the prediction of the total tract digestibility because microbial digestion in the caeca as well as endogenous losses in the large intestine alter the amount and composition of the excreted protein (Parsons 1984, Sibbald 1987). Therefore, the calculated digestibility coefficient for the total tract digestibility is a less accurate predictor of the available $C P$ and $A A$ than the calculated digestibility coefficient for the pc digestibility. Furthermore, when digestibility is studied, a decision must be made regarding the use of apparent, standardised, or true 
digestibility. The apparent $\mathrm{pc}$ digestibility is, for example, summarised in feed value tables of Bryden et al. (2009). Due to the correction for basal endogenous losses (Stein et al. 2007), standardised pc digestibility coefficients were described as more accurate in diet formulation than apparent pc digestibility coefficients (Kong \& Adeola 2014). In addition to basal endogenous losses, specific endogenous losses, which depend on characteristics of the test feedstuff (Sklan \& Hurwitz 1980, Golian et al. 2008) and can therefore increase with increasing proportions of the test feedstuff (Figure 1), are considered in the true pc digestibility (Stein et al. 2007).

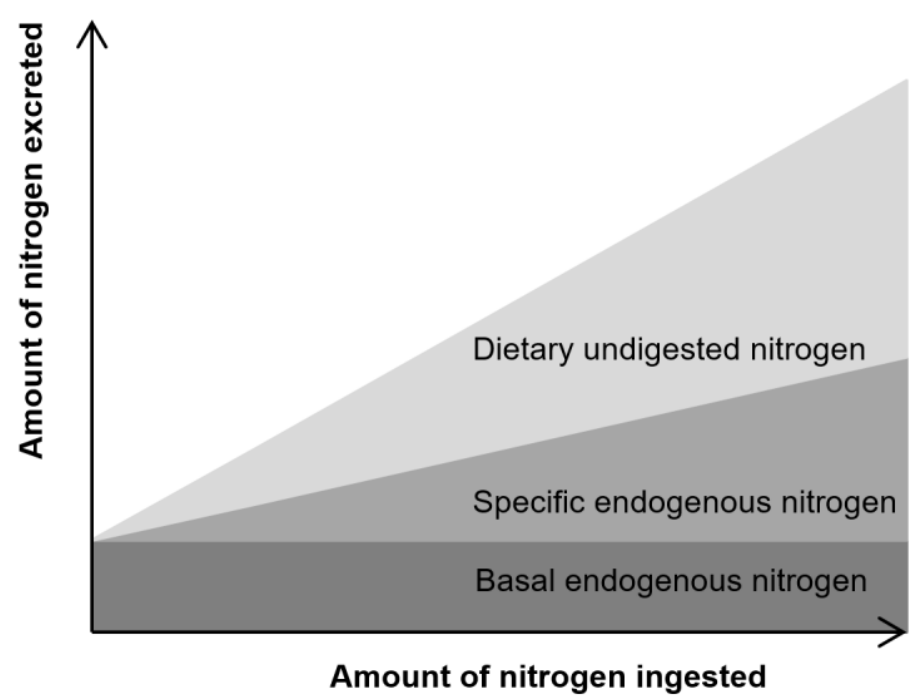

Figure 1: $\quad$ Origin of excreted nitrogen

(adapted from McDonald et al. 2002)

Thus, the difference between standardised and true pc digestibility of the CP and AA contained by the test feedstuff depend on the inclusion rate of the test feedstuff as well as its ability to increase endogenous losses. High dietary fibre contents can increase the secretion of digestive enzymes (Parsons et al. 1983, Angkanaporn et al. 1997). In addition, specific endogenous losses can be caused by the protein source (Angkanaporn et al. 1997) or increased due to high concentrations of starch and sugar (Kong \& Adeola 2013) or antinutritive factors (Cowieson \& Ravindran 2007, Cowieson et al. 2008). Thus, it is difficult to make reliable corrections for specific endogenous losses.

A major problem is that it is often not clearly stated which digestibility - apparent, true, standardised, or real total tract or pc digestibility - is displayed in tables and whether it was determined using ileal chyme or excreta (of cecectomised animals). Since the table values are descriptors for different measures, they cannot be easily subjected to comparison. Even if it is known which kind of digestibility is shown, the underlying assay that was used for the determination could have affected the displayed values. There are diverse reports regarding the comparability of the results of various in vivo studies on poultry of different origin and performance. Although some studies did not find significant differences, for example 
between three in vivo assays with chicks and roosters (Kim 2010), differences between assay methods were observed in other studies (Huang et al. 2006, Ravindran et al. 2017). As a consequence, Ravindran et al. (2017) stated the importance of the implementation of a standard method. To exclude a possible effect of different assay methods and to ensure that a prediction of the digestibility is possible using an in vitro assay, one underlying in vivo method was used for all tested feedstuffs of the present study.

In the linear regression approach that was deployed to determine the pc digestibility of the calibration samples (Rodehutscord et al. 2004), the CP or AA intake of broiler chicken fed three diets containing different proportions of the test feedstuff is related to the amount of residual $\mathrm{CP}$ or $\mathrm{AA}$ at the terminal ileum via regression analysis. The slope of the regression is equivalent to the pc digestibility, which is already corrected for basal endogenous losses but includes specific endogenous losses as an important determinant of nutritive protein quality (hereafter pc digestibility). The majority of the test feedstuffs used in the present study contained high amounts of at least one of these ingredients, indicating high specific endogenous losses, which affected the digestibility coefficients.

Altogether, the capabilities of in vitro assays to predict the in vivo digestibility of nutrients are limited because the digestibility of the nutrients is not only dependent on the feedstuff but also on the animal and its housing environment. There are many interactions between the feedstuff and the animal. A feedstuff can, for example, affect the microflora of the digestive tract, the viscosity of the digesta, and, consequently, the performance of the chick (Saki et al. 2010). However, this can also be an asset of the method because predictions that are independent of the animal are better descriptors of the feedstuff itself. Thus, in vitro methods can be used as an indicator of in vivo measures and give valuable predictions for diet formulation.

In vitro assays typically cannot be used to simulate endogenous losses or microbial digestion. Due to this fact, they are also used to predict the bioavailability of CP and AA (Galibois et al. 1989). Moreover, as a consequence of the inability of in vitro assays to simulate endogenous losses and microbial digestion in vitro rates of disappearance display the true $\mathrm{pc} \mathrm{CP}$ and $\mathrm{AA}$ digestibility rather than the apparent one. The in vitro rate of $\mathrm{CP}$ disappearance in the present study was used to predict the pc CP and AA digestibility, which is comparable to the standardised CP and AA digestibility because it is corrected for basal endogenous losses (Kong \& Adeola 2014). The prediction was accurate although high specific endogenous losses can be assumed for the majority of the tested feedstuffs.

The adaption of the multi-enzyme assay of Boisen \& Fernández (1995) showed that the lack of robustness can be a difficulty in the in vitro prediction of the digestibility of CP and AA of plant feedstuffs. Yet, robustness is a major requirement for laboratory analyses (Butts et al. 2012). Thus, measures must be taken to make the analysis results replicable and 
valid. In the present study, the use of centrifuge tubes during the whole analysis and the increase in the amount of finely ground sample material contributed to an enhanced robustness. This can also contribute to the comparability of results from different laboratories.

By now, the equations used to predict the CP and AA digestibility in the described in vitro assay were based on a regression including in vivo results of eleven different feedstuffs. Although the regressions had satisfying coefficients of determination, it is recommended to expand the number of feedstuffs used for method calibration to increase its validity. Furthermore, it would be of interest to relate the in vitro rate of $\mathrm{CP}$ and $\mathrm{AA}$ disappearance to the pc digestibility of a selection of samples originating from the same type of feedstuff to validate the method. The need for calculations with a selection of samples originating from the same type of feedstuff became specifically apparent, as wide variations have been reported in the literature and differences among literature/table values were large. Thus, a comparison with the in vitro CP and AA digestibility, which also varied widely, was difficult.

Since rapid, cheap, and simple analyses are required, it is desirable to use the in vitro CP disappearance also to predict the AA digestibility, as it is currently done within the described in vitro assay. However, a further characterisation of the in vitro disappearance of the AA could be suitable to develop better predictions of the pc digestibility of the AA in broiler chicken.

Even though it is generally known, it must be mentioned that the analysis method and the laboratory where analyses are conducted largely affect the results. The same plant feedstuffs were analysed for their CN and AA contents in a study by Ritteser (2015) and in the present study. However, the analysis results differed. This must be considered when results are to be compared or used in the same equation. Consequently, for animal trials or in vitro analyses, the feedstuffs and the digesta/residuals must be analysed in the same laboratory. All samples of the present study were analysed in the same laboratory and using the same methods. They are, therefore, comparable with each other. When compared with values reported in the literature, the effect of the analysis method and the laboratory must be considered.

Although it is commonly assumed that organically produced crops differ in their nutrient composition from conventionally produced crops (Strobel et al. 2001, Rossi et al. 2006, Böhm et al. 2007), little evidence for regular differences of the CN and AA composition can be found in the literature (Dangour et al. 2009). Some studies were conducted on foods used in human nutrition. Meta-studies report the tendency of lower CP and nitrate concentrations in organically produced crops (Bourn \& Prescott 2002, Magkos et al. 2003, 
Rossi et al. 2006, Brandt et al. 2011). Additionally, a better protein quality as measured by its concentration of essential AA (specifically lysine) was reported (Wolfson \& Shearer 1981, Worthington 2001, Winter \& Davis 2006). This observation is most likely due to differences in the fertilisation management (Brandt et al. 2011) Nitrogen excess has been reported to result in an enhanced CP synthesis, a decreased carbohydrate synthesis, and an increased deposition of nitrate (Worthington 2001). The present study did not aim to compare production forms but rather to characterise organic cereals and grain legumes as feedstuffs for monogastric animals in organic farming. Due to the large selection of organically produced crops that were analysed for their $\mathrm{CN}, \mathrm{AA}$, thiamine, and riboflavin concentrations, the present study had the potential to describe organically produced cereal and grain legume seeds comprehensively. Nevertheless, the available information on the composition and nutrient digestibility of feedstuffs is either mostly derived from conventionally cultivated crops or information on their underlying production is lacking. Thus, a comparison with table values is often most likely a comparison with values derived from conventionally produced crops. Such a comparison with the tables provided by INRA-CIRAD-AFZ (2018) and Evonik (2016) showed that the minimum CP and AA content of the sample set was in some cases lower than the minimum values in feed value tables and vice versa for starch contents. This could also be observed for the mean values. The Lys concentration in the CP of oats, peas and blue lupins, as well as the His concentration of all cultivars except for barley, were higher than the table values. However, the shifts in the AA composition strongly depended on the cultivar and the CP level. The observed ranges of the other $\mathrm{CN}$ contents of cereals and grain legumes were in accordance with the existing table values (Evonik 2016, INRACIRAD-AFZ 2018). The results were in agreement with the above-described tendencies for differences between organic and conventional plant foods.

Due to their high contents of starch, cereals are important energy suppliers. They are major components of mixed feed because large amounts are available in good quality for a reasonable price. Furthermore, high proportions can be applied in the diet without detrimental effects. However, variations of the $\mathrm{CN}$ and $\mathrm{AA}$ composition can make it difficult to formulate a diet. For example, in the present study, CP, starch and NfE contents varied by about $6 \%$ of the DM in each cereal cultivar. Furthermore, in the present study, wheat had the highest mean CP contents. Its CP contained low amounts of EAA, Ala, Gly, and Asp but high amounts of Pro and Glu and was therefore not of high quality. Winter rye and winter barley had the lowest CP content. However, the CP contained more Lys and Met and less Glu than the CP of wheat. Wide variations of the AA contents in the CP of all cereals are most likely due to shifts in the proportion of different protein fractions that differ in their AA composition (Casey et al. 1982, Shewry 2007, Carbonaro et al. 2015). They lead also to widely varying amino acid ratios (AAR) of the protein, which can be problematic in 
practical feed formulation based on the ideal AAR (IAAR). Altogether, cereals contribute greatly to the supply of SAA, which is of special importance in organic agriculture. The in vitro CP digestibility, which predicts the standardised pc CP digestibility in 42-day old broiler chicken, was with $0.71-0.83$ the lowest for barley and with $0.80-0.90$ the highest for winter wheat. These results were comparable with reports of Bandegan et al. (2011), who determined a standardised pc CP digestibility of five barley samples between $0.74-0.83$ and of five wheat samples between $0.86-0.89$. Altogether, the $C P$ and AA digestibility coefficients reported in the literature vary widely. A comparison with table values is specifically difficult as often only mean values (or even a single value) are reported. The variations of the nutrient content and the CP digestibility make it even more difficult to predict the nutritive value of different batches of cereals for monogastric animal feeding cereals can be of great value not only as the energy supplier but also as the supplier of other nutrients including such AA as the SAA, Thr, and Trp. However, to be used precisely in diet optimisation, analysis or good predictions of the nutrient composition and the pc CP and AA digestibility are required.

The amino acid gap has been extensively discussed in the last two decades and is a persisting problem in monogastric animal feeding in organic farming (Weißmann et al. 2005, Zeltner \& Maurer 2009, Smith et al. 2014). The allowance to feed some conventionally produced protein feedstuffs is a compromise that was made to ensure animal health and welfare. Legumes are valuable crops regarding their ecological and agricultural benefits (e. g., soil fertility, biodiversity)(Stockdale et al. 2006, Watson et al. 2006, Köpke \& Nemecek 2010) as well as in terms of their nutritional quality (Fernández et al. 1996, Urbano et al. 2005, Sujak et al. 2006, Koivunen 2016). Due to high CP contents with large amounts of Lys, they can enhance the CP content of the diet and compensate for low Lys contents in cereals. Thus, they can be beneficial in closing the AA gap. Home-grown grain legumes can partially replace soybean meal in diets for monogastric animals (Koivunen et al. 2016). However, like in other crops, the $\mathrm{CN}$ and $\mathrm{AA}$ composition as well as the pc digestibility of $\mathrm{CP}$ and $\mathrm{AA}$ can vary widely in grain legumes. In the present study, the CP content of blue lupins varied by $14 \%$ of the DM, their NfE content by $13 \%$, and their starch content by $6 \%$ of the DM. Similar variations were observed in peas and beans. The CP content of peas varied by $10.5 \%$ of the DM. Some pea samples had CP contents that were comparable to the ones of winter wheat. Evonik (2016) reported a mean CP content of field peas of $23.6 \% \mathrm{DM}$, which is nearly $9 \%$ higher than the lowest content and more than $2 \%$ higher than the mean content determined in the present study. These wide variations were mirrored in the AA composition of the $\mathrm{CP}$ and in the in vitro $\mathrm{CP}$ and $\mathrm{AA}$ digestibility coefficients. They make diet formulation particularly challenging and nutrient analyses or predictions necessary. 
The ability of practical diets to meet the IAAR, which depends on the animal species and a variety of further factors (e. g., age and performance), is limited. Still, the knowledge of the AA contents can improve diet formulation to achieve effective use of $\mathrm{N}$ and, thus, decrease its excretion and improve animal performance, health, and welfare (Jongbloed \& Lenis 1992, Van Krimpen et al. 2005, Rodenburg et al. 2008, Chalova et al. 2016) also in organic farming. However, when CP contents of the diet are deliberately decreased, it is important to consider not only the effect on performance and overall health but also on animal welfare. Diets with low CP levels can for example decrease broiler performance and lead to hunger reactions, like feather eating and feed spillage, although it need not affect the immune reaction of broiler chicken negatively (Eriksson et al. 2009). An improved AA profile of a low $\mathrm{CP}$ diet has the potential to reduce these reactions and is known to prevent growth depression and other deficiency symptoms in piglets (Le Bellego \& Noblet 2002). Since AA analyses are quite expensive, the prediction of their contents from the CP content of a feedstuff by equations is common in agricultural practice (e. g., Evonik 2016, Ajinomoto Animal Nutrition Group 2014). Although the values obtained by using equations can deviate from the results obtained via analysis, they can be used to predict an approximate AA composition of cereals and grain legumes and are supported by the results of the present study.

In farm animal feeding in organic farming, another compromise is made with regard to the $B$ vitamin supply. B vitamins are water-soluble, readily excreted, and thus not stored in the body. Therefore, the dietary oversupply is continuously excreted with urine (Roth-Maier et al. 1999) despite the constant requirement for B vitamins in metabolism (McDowell 2006). This makes their continuous dietary supply necessary. Since B vitamin deficiencies have strong negative effects on animal health, some supplements are allowed to be used in organic farming but native contents must be considered, nevertheless. The thiamine and riboflavin contents in cereals determined in the present study were mostly lower than expected from table values, while grain legumes contained also low but more similar amount of both B vitamins (Sauvant et al. 2004, USDA 2016). However, comparably low contents have been repeatedly reported in the literature (Olkowski 2008, Buchholz et al. 2012). The differences between the studies might be related to the used analysis method (Hollman et al. 1993), the storage time and conditions (Finglas 2003), or different cultivation conditions (Shewry et al. 2011). However, the value of cereals and grain legumes as suppliers of thiamine and riboflavin was confirmed in the present study.

It was shown in this study that recommended amounts of thiamine are usually supplied without any supplementation in exemplary diets for pigs and chicken in organic farming. However, it is important to consider the bioavailability of thiamine. The availability of thiamine in the diet can be affected by naturally occurring antagonists. The enzyme 
thiaminase can be found in raw fish, in some plants, fungi, and microorganisms (Kawasaki \& Ono 1968, Plitt 1995). Plants can also contain antagonistic hydroxypolyphenols, like caffeic acid, chlorogenic acid, and tannic acid, which are heat-stable and render the thiamine unable to be absorbed (Baker 1995, McDowell 2000). Additionally, plant flavonoids, like quercetin and rutin, can be antagonistic to thiamine (Murata et al. 1974, Murata et al. 1976) and thiamine analogues can affect thiamine availability (Hemming \& Gubler 1980). Furthermore, metabolic rate (i.e. age, body size, health status) affect thiamine requirement (McDowell 2000). Thiamine contents in feedstuffs can decrease due to suboptimal storage conditions, since thiamine is heat labile at neutral $\mathrm{pH}$ and freely watersoluble (Prodanov et al. 2004). In addition, it is unstable under alkaline conditions (Finglas 2003, Combs Jr. \& McClung 2017). However, the stability of thiamine in compounds can be different (Baker 1995). Shurson et al. (2011) reported a decrease of thiamine concentration in premixes during storage at ambient temperature. Nevertheless, thiamine deficiency appears rather unlikely when healthy animals are fed a cereal-based diet that was stored under dry and cool conditions. Pc digestibility coefficients of 0.94 for barley thiamine, 0.89 for wheat thiamine, and 0.84 for rye thiamine were reported (Roth-Maier et al. 1999, RothMaier \& Paulicks 2003). Due to the above-described factors, a thiamin deficiency can occur. However, it is rather unlikely, when the feedstuffs are carefully handled and processed and are not stored over a long period of time.

Considering the results of the present study, riboflavin is likely to be deficient in diets for monogastric animals in organic farming. This is rather problematic because riboflavin supplements are generally produced via fermentation with GMO (Stahmann et al. 2000, Schwechheimer et al. 2016, Revuelta et al. 2017), which are banned in organic farming. Furthermore, it must be considered that the riboflavin content in feedstuffs can decrease during storage and processing. Extrusion was reported to decrease the amount of available thiamine and riboflavin in peas (Frias et al. 2011). Storage conditions must therefore be well monitored. Although riboflavin remains stable when exposed to heat and oxygen and is only moderately soluble in water and ethanol, it is sensitive to sunlight (Choe et al. 2005) and unstable under alkaline conditions and irradiation as well as in the presence of metals and reducing agents (Finglas 2003, Combs Jr. \& McClung 2017). It is of benefit to choose a storing place in consideration of these conditions and store feedstuffs in a dark and dry place. In addition, it must be considered that some antagonists and analogues diminish the bioavailability of riboflavin (Mack \& Grill 2006, Combs Jr. \& McClung 2017). As a consequence, the native riboflavin contents should be considered in diet formulation with caution. It is necessary to find ways to improve the supply of riboflavin, although it has been reported that riboflavin supply $18 \%$ below the recommendations does not necessarily impair the growth performance of broiler chicken (Roth-Maier \& Kirchgeßner 1997 in Roth-Maier 
\& Paulicks 2002). In cereals, riboflavin is contained by the germ and the hulls (Batifoulier et al. 2006). Since cereal refining for animal feeding is not common, maximum contents of riboflavin are contained in feed cereals. The only way to improve the riboflavin content in cereals and grain legumes seem to be germination (Bau et al. 1997, Prodanov et al. 1997, Sierra \& Vidal-Valverde 1999, Mehta et al. 2007). Germination is also known to decrease the contents of some anti-nutritive factors (Gefrom et al. 2013). However, Schwediauer et al. (2017) concluded that germination of faba beans is not suitable in terms of nutrients and acceptance. Since riboflavin can mainly be found in milk products, eggs, meat, and green vegetables (Batifoulier et al. 2006), the use of egg or milk powder seems to be another promising solution. However, animal products are not primarily supposed to be used in farm animal nutrition. Furthermore, the present study confirmed the value of grass-land derived products in the contribution of riboflavin. Since pasture and roughage are commonly used in organic farming, their contribution to the riboflavin (and thiamine) supply should be further evaluated. An inclusion of yeast in diets for farm animals can also be beneficial in feedstuffs for monogastric animals. Yeast can be added in small amounts, but it contains large amounts of CP (58\% DM), minerals, and vitamins, including riboflavin (7.2 mg/100g DM) and thiamine (5.6 mg/100g DM; (USDA 2018). When native contents of dietary riboflavin are not sufficient after all, supplements could be produced by chemical synthesis (Bretzel et al. 1999). Due to the growing consumer demand for GMO-free foods, the production of riboflavin by chemical synthesis might increase again. In conclusion, a sufficient supply of riboflavin remains a major issue in organic farming.

For practical ration formulation, it would be useful to have a tool to approximately predict the nutrient composition of the single feedstuffs. Both the results of the present study and reports in the literature showed that variety and environmental conditions can strongly affect nutrient composition (Kim et al. 2003, Murphy et al. 2009, Shewry et al. 2010, Rodehutscord et al. 2016) and nutrient digestibility (Ravindran et al. 2014, Rosenfelder et al. 2015, Spindler et al. 2016, Zuber et al. 2016). However, a large number of influencing factors as well as interactions between variety and environmental conditions prevent the prediction of the nutrient composition based on variety and environmental conditions. Balanced studies, repeatedly conducted under the same conditions with the same varieties, could provide information that is more accurate. Yet, the environmental conditions cannot be held constant in the field, and breeding programs continually provide new varieties. Due to repeatedly conducted variety trials, some studies of the plant breeding companies, and some research experiments (e. g., Daveby et al. 1993, Jørgensen et al. 1999, Kim et al. 2003, Gutiérrez-Alamo et al. 2008, Hornick 2009, Kotlarz et al. 2011, Shewry et al. 2011), several regularities of effects are known. For example, it is known that the time and intensity of rainfall alter the $\mathrm{CN}$ and vitamin concentrations, that the ripening state at harvest affects 
nutrient content and is crucial for the relation between starch and CP content, and that specific varieties contain low amounts of ANF or high amounts of CP with a specific composition. The present study confirmed the existence of varietal and environmental effects on the concentration of $\mathrm{CN}$, starch, thiamine, and riboflavin as well as on the in vitro digestibility of CP and AA. However, it does not allow to draw conclusions on the direction and extent of the varietal and environmental effects on the nutrient composition and digestibility of specific samples. It is unlikely that it will be possible to precisely predict the nutrient composition of crops in the future. 


\section{Conclusions}

The results of the present study confirmed wide variations of the crude nutrient, amino acid, thiamine, and riboflavin contents of organic cereals and grain legumes. In comparison to table values, the crude protein, thiamine, and riboflavin content of cereal and grain legumes tended to be lower and the starch content tended to be higher. Additionally, the amino acid profile of the crude protein differed from literature values. Decreasing crude protein contents were associated with decreasing concentrations of the amino acids phenylalanine, proline, and glutamine/glutamic acid in the crude protein of cereals and arginine in the crude protein of grain legumes, while the concentration of some other amino acids, including lysine, methionine, threonine, and tryptophan, increased. In terms of the amino acid gap in organic farming, which is foremost based on the lack of sulphur-containing amino acids in diets for monogastric animals, the results indicated a better protein quality in cereals and grain legumes with low crude protein contents. Low crude protein contents of organically cultivated crops could therefore have an advantage in the formulation of diets with decreased levels of crude protein. However, low crude protein, amino acid, and riboflavin contents of cereals and grain legumes, which are commonly used feedstuffs for monogastric animals, could also add to already existing shortcomings.

Either way, the nutrient composition of single feedstuffs must be known to optimise a diet. The enormous variability of the nutrient contents and the strong but unpredictable effects of genetic and especially environmental factors on the nutrient composition of cereals and grain legumes make it difficult to predict it. Furthermore, the use of table values becomes deceptive, when wide variations of the tabulated nutrients occur unpredictably. However, crude protein analysis can be conducted with quick and cheap methods. When the crude protein content of a sample is known, the contents of the amino acids of cereals and grain legumes can be satisfactorily predicted using equations, which were provided by the present study. An accurate estimation of the amino acid contents can also give information on the amino acid profile of the dietary protein.

Furthermore, the content of digestible amino acids in single feedstuffs is commonly used in diet formulation for monogastric animals. As observed in the present study, the precaecal crude protein and amino acid digestibility of organically cultivated grain legumes in broiler chicken can be high. Nevertheless, wide variations of the precaecal crude protein and amino acid digestibility were reported in the literature. Data tables that provide information on the precaecal crude protein and amino acid digestibility of cereals and grain legumes are less extensive than tables providing information on the nutrient composition. Thus, it is crucial to improve the data situation. The adapted in vitro assay of the present study can be used to predict the precaecal crude protein and amino acid digestibility in feedstuffs for 
broiler chicken and thus to enhance the data basis with little impact on animal welfare. However, the standardisation of the underlying in vivo method is recommended. The effect of the environmental conditions on the in vitro crude protein and amino acid digestibility was high. An optimised cultivation management might be more important for improving the precaecal crude protein and amino acid digestibility and the nutrient composition of cereals and grain legumes than the choice of variety. Further validation of the assay using combined in vivo and in vitro studies are recommended to improve the applicability of the introduced assay.

The supply of B vitamins, especially riboflavin, and the supply of precaecally digestible essential AA remains a complex topic. Since animal health and welfare are of utmost importance in animal keeping per se, the sufficient dietary supply of nutrients must be ensured by supplementing critical nutrients if necessary. To enable $100 \%$ organic feeding, it is of interest to study the composition and applicability of feedstuffs with high contents of limiting amino acids as well as riboflavin. Furthermore, an improved applicability of simple predictions for the nutrient composition and digestibility can be beneficial in $100 \%$ organic feeding. 


\section{References - General Discussion}

Ajinomoto Animal Nutrition Group (2014). Ajinomoto Eurolysine S.A.S. Laboratory Analysis Database, http://ajinomoto-eurolysine.com/feedstuffs-amino-acid-database.html, Last Access 25th of June 2018.

Angkanaporn, K., Ravindran, V. and Bryden, W.L. (1996). Additivity of Apparent and True lleal Amino Acid Digestibilities in Soybean Meal, Sunflower Meal, and Meat and Bone Meal for Broilers. Poult Sci 75, 1098-1103. DOI: 10.3382/ps.0751098

Angkanaporn, K., Ravindran, V., Mollah, Y. and Bryden, W.L. (1997). Evaluation of Homoarginine as a Marker for the Determination of Endogenous Amino Acid Concentrations in Poultry Excreta. Br Poult Sci 38, 577-585. DOI: 10.1080/00071669708418039

Baker, D.H. (1995). Vitamin Bioavailability, In: Ammermann, C.B., Baker, D. H. and Lewis, A. J. (Ed.), Bioavailability of Nutrients for Animals - Amino Acids, Minerals, and Vitamins, Academic Press. ISBN: 012-056250-2

Bandegan, A., Golian, A., Kiarie, E., Payne, R.L., Crow, G.H., Guenter, W. and Nyachoti, C.M. (2011). Standardized Ileal Amino Acid Digestibility in Wheat, Barley, Pea and Flaxseed for Broiler Chickens. Can J Anim Sci 91, 103-111.DOI: 10.4141/CJAS10076

Batifoulier, F., Verny, M.A., Chanliaud, E., Rémésy, C. and Demigné, C. (2006). Variability of B Vitamin Concentrations in Wheat Grain, Milling Fractions and Bread Products. Eur J Agron 25, 163-169. DOI: 10.1016/j.eja.2006.04.009

Bau, H.M., Villaume, C., Nicolas, J.P. and Méjean, L. (1997). Effect of Germination on Chemical Composition, Biochemical Constituents and Antinutritional Factors of Soya Bean (Glycine Max) Seeds. J Sci Food Agr 73, 1-9. DOI: 10.1002/(SICI)1097-0010(199701)73:1<1::AID-JSFA694>3.0.CO;2-B

Böhm, H., Aulrich, K. and Berk, A. (2007). Rohprotein- und Aminosäurengehalte in Körnerleguminosen und Getreide [Crude Protein and Amino Acid Contents on Grain Legumes and Cereals], In: Zikeli, S., Claupein, W., Dabbert, S., Kaufmann, B., Müller, T. and Valle Zárate, A. (Eds.), 9. Wissenschaftliche Jahrestagung Ökologischer Landbau, Hohenheim.

Boisen, S. and Fernández, J.A. (1995). Prediction of the Apparent lleal Digestibility of Protein and Amino Acids in Feedstuffs and Feed Mixtures for Pigs by in Vitro Analyses. Anim Feed Sci Tech 51, 29-43. DOI: 10.1016/0377-8401(94)00686-4

Bourn, D. and Prescott, J. (2002). A Comparison of the Nutritional Value, Sensory Qualities, and Food Safety of Organically and Conventionally Produced Foods. Crit Rev Food Sci Nutr 42, 1-34. DOI: $10.1080 / 10408690290825439$

Brandt, K., Leifert, C., Sanderson, R. and Seal, C.J. (2011). Agroecosystem Management and Nutritional Quality of Plant Foods: The Case of Organic Fruits and Vegetables. Crit Rev Plant Sci 30, 177-197. DOI: 10.1080/07352689.2011.554417

Bretzel, W., Schurter, W., Ludwig, B., Kupfer, E., Doswald, S., Pfister, M. and van Loon, A.P.G.M. (1999). Commercial Riboflavin Production by Recombinant Bacillus Subtilis: Down-Stream Processing and Comparison of the Composition of Riboflavin Produced by Fermentation or Chemical Synthesis. J Ind Microbiol Biotechnol 22, 19-26. DOI: 10.1038/sj.jim.2900604

Bryden, W.L., Li, X., Ravindran, G., Hew, L.I. and Ravindran, V. (2009). Ileal Digestible Amino Acid Values in Feedstuffs for Poultry. Rural Industries Research and Development Corporation. ISBN: 1741518709

Buchholz, M., Drotleff, A.M. and Ternes, W. (2012). Thiamin (Vitamin B1) and Thiamin Phosphate Esters in Five Cereal Grains During Maturation. J Cereal Sci 56, 109-114. DOI: 10.1016/j.jcs.2011.11.009.

Butts, C.A., Monro, J.A. and Moughan, P.J. (2012). In Vitro Determination of Dietary Protein and Amino Acid Digestibility for Humans. Br J Nutr 108, S282-S287. DOI:10.1017/S0007114512002310

Carbonaro, M., Maselli, P. and Nucara, A. (2015). Structural Aspects of Legume Proteins and Nutraceutical Properties. Food Res Int 76, 19-30. DOI: 10.1016/j.foodres.2014.11.007

Casey, R., Sharman, J.E., Wright, D.J., Bacon, J.R. and Guldager, P. (1982). Quantitative Variability in Pisum Seed Globulins: Its Assessment and Significance. Plant Food Hum Nutr 31, 333-346. DOI: 10.1007/BF01094045

Chalova, V.I., Kim, J., Patterson, P.H., Ricke, S.C. and Kim, W.K. (2016). Reduction of Nitrogen Excretion and Emission in Poultry: A Review for Organic Poultry. J Environ Sci Health, Part B 51, 230-235. DOI: $10.1080 / 03601234.2015 .1120616$

Choe, E., Huang, R. and Min, D.B. (2005). Chemical Reactions and Stability of Riboflavin in Foods. J Food Sci 70, R28-R36. DOI: 10.1111/j.1365-2621.2005.tb09055.x

Combs Jr., G.F. and McClung, J.P. (2017). The Vitamins - Fundamental Aspects in Nutrition and Healh. 5th Edition. Academic Press. ISBN: 978-0-12-802965-7 
Cowieson, A.J. and Ravindran, V. (2007). Effect of Phytic Acid and Microbial Phytase on the Flow and Amino Acid Composition of Endogenous Protein at the Terminal lleum of Growing Broiler Chickens. Br J Nutr 98, 745-752. DOI: 10.1017/S0007114507750894

Cowieson, A.J., Ravindran, V. and Selle, P.H. (2008). Influence of Dietary Phytic Acid and Source of Microbial Phytase on Ileal Endogenous Amino Acid Flows in Broiler Chickens. Poult Sci 87, 2287-2299. DOI: 10.3382/ps.2008-00096

Dangour, A.D., Dodhia, S.K., Hayter, A., Allen, E., Lock, K. and Uauy, R. (2009). Nutritional Quality of Organic Foods: A Systematic Review. Am J Clin Nutr 90, 680-685. DOI: 10.3945/ajcn.2009.28041

Daveby, Y.D., Abrahamsson, M. and Åman, P. (1993). Changes in Chemical Composition During Development of Three Different Types of Peas. J Sci Food Agr 63, 21-28. DOI: 10.1002/jsfa.2740630105

Eriksson, M., Waldenstedt, L., Engström, B. and Elwinger, K. (2009). Protein Supply in Organic Broiler Diets. Acta Agr Scand a-An 59, 211-219. DOI: 10.1080/09064700903358256

Evonik (2016). Evonik Nutrition \& Care Gmbh. Aminodat 5.0, Version 1.03.

Fernández, M., López-Jurado, M., Aranda, P. and Urbano, G. (1996). Nutritional Assessment of Raw and Processed Faba Bean (Vicia Faba L.) Cultivar Major in Growing Rats. J Agr Food Chem 44, 27662772. DOI: $10.1021 / \mathrm{Jf} 9505483$

Finglas, P.M. (2003). Vitamins, In: Caballero, B., Finglas, P. M., Trugo, L. C. (Ed.), Encyclopedia of Food Sciences and Nutrition, pp. 6046-6053. ISBN: 978-0-12-227055-0

Frias, J., Giacomino, S., Peñas, E., Pellegrino, N., Ferreyra, V., Apro, N., Carrión, M.O. and Vidal-Valverde, C. (2011). Assessment of the Nutritional Quality of Raw and Extruded Pisum Sativum L. Var. Laguna Seeds. LWT Food Sci Technol 44, 1303-1308. DOI: 10.1016/j.Iwt.2010.12.025

Fuller, M. (2012). Determination of Protein and Amino Acid Digestibility in Foods Including Implications of Gut Microbial Amino Acid Synthesis. Br J Nutr 108, S238-S246. doi:10.1017/S0007114512002279

Galibois, I., Savoie, L., Simoes Nunes, C. and Rérat, A. (1989). Relation between in Vitro and in Vivo Assessment of Amino Acid Availability. Reprod Nutr Dev 29, 495-507.

Gefrom, A., Ott, E.M., Hoedtke, S. and Zeyner, A. (2013). Effect of Ensiling Moist Field Bean (Vicia Faba), Pea (Pisum Sativum) and Lupine (Lupinus Spp.) Grains on the Contents of Alkaloids, Oligosaccharides and Tannins. J Anim Physiol Anim Nutr 97, 1152-1160. DOI: 10.1111/jpn.12024

Golian, A., Guenter, W., Hoehler, D., Jahanian, H. and Nyachoti, C.M. (2008). Comparison of Various Methods for Endogenous Ileal Amino Acid Flow Determination in Broiler Chickens. Poult Sci 87, 706-712. DOI: $10.3382 / p s .2007-00330$

Gutiérrez-Alamo, A., Pérez De Ayala, P., Verstegen, M.W.A., Den Hartog, L.A. and Villamide, M.J. (2008). Variability in Wheat: Factors Affecting Its Nutritional Value. World Poult Sci J 64, 20-39. DOI: $10.1017 /$ S0043933907001699

Hemming, B.C. and Gubler, C.J. (1980). Separation of Thiamin, Thiamin Antagonists and Their Phosphate Esters by High-Performance Liquid Chromatography. J Liq Chromatogr 3, 1697-1712. DOI: 10.1080/01483918008064761

Hollman, P.C.H., Slangen, J.H., Wagstaffe, P.J., Faure, U., Southgate, D.A.T. and Finglas, P.M. (1993). Intercomparison of Methods for the Determination of Vitamins in Foods. Part 2. Water-Soluble Vitamins. Analyst 118, 481-488. DOI: 10.1039/AN9931800481

Hornick, S.B. (2009). Factors Affecting the Nutritional Quality of Crops. Am J Altern Agric 7, 63-68. DOI: $10.1017 /$ S0889189300004471

Huang, K.H., Li, X., Ravindran, V. and Bryden, W.L. (2006). Comparison of Apparent lleal Amino Acid Digestibility of Feed Ingredients Measured with Broilers, Layers, and Roosters. Poult Sci 85, 625-634. DOI: $10.1093 / \mathrm{ps} / 85.4 .625$

INRA-CIRAD-AFZ (2018). INRA-CIRAD-AFZ Feed Tables - Composition and Nutritive Values of Feeds for Cattle, Sheep, Goats, Pigs, Poultry, Rabbits, Horses and Salmonids, https://feedtables.com/, Last Access 1st August 2018.

Jezierny, D., Mosenthin, R., Sauer, N., Roth, S., Piepho, H.P., Rademacher, M. and Eklund, M. (2011). Chemical Composition and Standardised lleal Digestibilities of Crude Protein and Amino Acids in Grain Legumes for Growing Pigs. Livest Sci 138, 229-243. DOI: 10.1016/j.livsci.2010.12.024

Jongbloed, A.W. and Lenis, N.P. (1992). Alteration of Nutrition as a Means to Reduce Environmental Pollution by Pigs. Livest Prod Sci 31, 75-94. DOI: 10.1016/0301-6226(92)90057-B

Jørgensen, H., Gabert, V.M. and Fernández, J.A. (1999). Influence of Nitrogen Fertilization on the Nutritional Value of High-Lysine Barley Determined in Growing Pigs. Anim Feed Sci Tech 79, 79-91. DOI: 10.1016/S0377-8401(99)00011-5

Kawasaki, M. and Ono, T. (1968). Studies on Thiaminase of Fungi. 1. Thiaminase of Lentinus Edodes (Berg.) Sing. Vitamins $37,44-49$. ISSN: 0006-386X 
Kim, E.J. (2010). Amino Acid Digestibilities of Various Feedstuffs Using Different Methods. Dissertation, University of Illinois at Urbana-Champaign.

Kim, J.C., Mullan, B.P., Simmins, P.H. and Pluske, J.R. (2003). Variation in the Chemical Composition of Wheats Grown in Western Australia as Influenced by Variety, Growing Region, Season, and Post-Harvest Storage. Aust J Agr Res 54, 541-550. DOI: 10.1071/Ar02183

Koivunen, E. (2016). Home-Grown Grain Legumes in Poultry Diets. Dissertation, University of Helsinki.

Koivunen, E., Partanen, K., Perttilä, S., Palander, S., Tuunainen, P. and Valaja, J. (2016). Digestibility and Energy Value of Pea (Pisum Sativum L.), Faba Bean (Vicia Faba L.) and Blue Lupin (Narrow-Leaf) (Lupinus Angustifolius) Seeds in Broilers. Anim Feed Sci Tech 218, 120-127. DOI: 10.1016/j.anifeedsci.2016.05.007

Kong, C. and Adeola, O. (2013). Ileal Endogenous Amino Acid Flow Response to Nitrogen-Free Diets with Differing Ratios of Corn Starch to Dextrose in Broiler Chickens. Poult Sci 92, 1276-1282. DOI: $10.3382 / p s .2012-02835$

Kong, C. and Adeola, O. (2014). Evaluation of Amino Acid and Energy Utilization in Feedstuff for Swine and Poultry Diets. Asian Austral J Anim 27, 917-925. DOI: 10.5713/ajas.2014.r.02

Köpke, U. and Nemecek, T. (2010). Ecological Services of Faba Bean. Field Crop Res 115, 217-233. DOI: 10.1016/j.fcr.2009.10.012

Kotlarz, A., Sujak, A., Strobel, W. and Grzesiak, W. (2011). Chemical Composition and Nutritive Value of Protein of the Pea Seeds - Effect of Harvesting Year and Variety. Veg Crop Res Bul 75, 57-69. DOI: 10.2478/v10032-011-0018-2

Le Bellego, L. and Noblet, J. (2002). Performance and Utilization of Dietary Energy and Amino Acids in Piglets Fed Low Protein Diets. Livest Prod Sci 76, 45-58. DOI: 10.1016/S0301-6226(02)00008-8

Mack, M. and Grill, S. (2006). Riboflavin Analogs and Inhibitors of Riboflavin Biosynthesis. Appl Microbiol Biotechnol 71, 265-275. DOI: 10.1007/s00253-006-0421-7

Magkos, F., Arvaniti, F. and Zampelas, A. (2003). Organic Food: Nutritious Food or Food for Thought? A Review of the Evidence. Intern J Food Sci Nutr 54, 357-371. DOI: 10.1080/09637480120092071

McDonald, P., Edwards, R.A., Greenhalgh, J.F.D., Morgan, A., Sinclair, L.A. and Wilkinson, R.G. (2002). Animal Nutrition, 7th Edition, Pg. 306. Pearson Publishing. Pearson.

McDowell, L.R. (2000). Vitamins in Animal and Human Nutrition, lowa State University Press / Ames. ISBN: 0-8138-2630-6

McDowell, L.R. (2006). Vitamin Nutrition of Livestock Animals: Overview from Vitamin Discovery to Today. Can J Anim Sci 86, 171-179. DOI: 10.4141/A05-057

Mehta, M.B., Mehta, B., Bapodra, A.H. and Joshi, H.D. (2007). Effect of Germination and Heat Processing on Protein, Riboflavin, Vit-C and Niacin Content in Peas, Cowpea, Redgram and Wheat. As J Home Sci 2, 34 - 38. ISSN: 0973-4732

Murata, K., Tanaka, R. and Yamaoka, M. (1974). Reaction Mechanisms of Thiamine with Thermostable Factors. J Nutr Sci Vitaminol 20, 351-362. DOI: 10.3177/jnsv.20.351

Murata, K., Yamaoka, M. and Ichikawa, A. (1976). Reactivation Mechanisms of Thiamine with Termostable Factors. J Nutr Sci Vitaminol 22, 7-12. DOI: 10.3177/jnsv.22.Supplement_7

Murphy, K.M., Hoagland, L.A., Reeves, P.G., Baik, B.-K. and Jones, S.S. (2009). Nutritional and Quality Characteristics Expressed in 31 Perennial Wheat Breeding Lines. Renew Agr Food Syst 24, 285-292. DOI: $10.1017 / S 1742170509990159$

Olkowski, B.I. (2008). Riboflavin Content in Lupine Seeds and Blood Plasma Riboflavin Status in Broilers Fed Diets Containing High Levels of Lupine Seeds. J Sci Food Agr 88, 2474-2478. DOI: 10.1002/Jsfa.3365

Parsons, C.M. (1984). Influence of Caecectomy and Source of Dietary Fibre or Starch on Excretion of Endogenous Amino Acids by Laying Hens. Br J Nutr 51, 541-548. DOI: 10.1079/BJN19840059

Parsons, C.M., Potter, L.M. and Brown, J.R.D. (1983). Effects of Dietary Carbohydrate and of Intestinal Microflora on Excretion of Endogenous Amino Acids by Poultry. Poult Sci 62, 483-489. DOI: $10.3382 / p s .0620483$

Plitt (1995). Einfluß von verpilztem Gras auf intraruminale Fermentation und Thiaminstoffwechsel des Rindes (in-vitro) [Influence of Fungal Grass on Intraruminal Fermentation and Thiamine Metabolism of Cattle (in-Vitro)]. Dissertation, University of Veterinary Medicine Hannover, Hannover, Tierärztl. Hochschule, Dissertation.

Prodanov, M., Sierra, I. and Vidal-Valverde, C. (1997). Effect of Germination on the Thiamine, Riboflavin and Niacin Contents in Legumes. Z Lebensm Unters F A 205, 48 - 52. DOI: 10.1007/s002170050122

Prodanov, M., Sierra, I. and Vidal-Valverde, C. (2004). Influence of Soaking and Cooking on the Thiamin, Riboflavin and Niacin Contents of Legumes. Food Chem 84, 271 - 277. DOI: $10.1016 /$ S0308-8146(03)00211-5 
Ravindran, V., Abdollahi, M.R. and Bootwalla, S.M. (2014). Nutrient Analysis, Metabolizable Energy, and Digestible Amino Acids of Soybean Meals of Different Origins for Broilers. Poult Sci 93, 2567-2577. DOI: $10.3382 / p s .2014-04068$

Ravindran, V., Adeola, O., Rodehutscord, M., Kluth, H., van der Klis, J.D., van Eerden, E. and Helmbrecht, A. (2017). Determination of Ileal Digestibility of Amino Acids in Raw Materials for Broiler Chickens Results of Collaborative Studies and Assay Recommendations. Anim Feed Sci Tech 225, 62-72. DOI: 10.1016/j.anifeedsci.2017.01.006

Revuelta, J.L., Ledesma-Amaro, R., Lozano-Martinez, P., Díaz-Fernández, D., Buey, R.M. and Jiménez, A. (2017). Bioproduction of Riboflavin: A Bright Yellow History. J Ind Microbiol Biot 44, 659-665. DOI: $10.1007 / \mathrm{s} 10295-016-1842-7$

Ritteser, C. (2015). Bestimmung präcecaler Verdaulichkeitskoeffizienten für heimische Energie- und Proteinfuttermittel für die Bio-Hühnermast [Estimation of Ileal Nutrient Digestibility of Native Energy and Protein Feeding Stuffs for Organic Broilers]. Dissertation, University of Hohenheim.

Rodehutscord, M., Kapocius, M., Timmler, R. and Dieckmann, A. (2004). Linear Regression Approach to Study Amino Acid Digestibility in Broiler Chickens. $\mathrm{Br}$ Poult Sci 45, 85-92. DOI: 10.1080/00071660410001668905

Rodehutscord, M., Rückert, C., Maurer, H.P., Schenkel, H., Schipprack, W., Bach Knudsen, K.E., Schollenberger, M., Laux, M., Eklund, M., Siegert, W. and Mosenthin, R. (2016). Variation in Chemical Composition and Physical Characteristics of Cereal Grains from Different Genotypes. Arch Anim Nutr 70, 87-107. DOI: 10.1080/1745039X.2015.1133111

Rodenburg, T.B., Van Harn, J., Van Krimpen, M.M., Ruis, M.A.W., Vermeij, I. and Spoolder, H.A.M. (2008) Comparison of Three Different Diets for Organic Broilers: Effects on Performance and Body Condition. Br Poult Sci 49, 74-80. DOI: 10.1080/00071660701823085

Rosenfelder, P., Mosenthin, R., Spindler, H.K., Jørgensen, H., Bach Knudsen, K.E., Sauer, N., Htoo, J.K. and Eklund, M. (2015). Standardized Ileal Digestibility of Amino Acids in Eight Genotypes of Soft Winter Wheat Fed to Growing Pigs. Anim Sci 93, 1133-1144. DOI: 10.2527/jas.2014-8079

Rossi, F., Bertuzzi, T., Comizzoli, S., Turconi, G., Roggi, C., Pagani, M., Cravedi, P. and Pietri, A. (2006). Preliminary Survey on Composition and Quality of Conventional and Organic Wheat. Ital J Food Sci 18, 355-366. ISSN: 11201770

Roth-Maier, D. and Paulicks, B.R. (2002). Effects of a Suboptimal Dietary Intake of Particular B-Vitamins on the Growth of Fattening Chicken. Arch Gefluegelk 66, 201-205. ISSN: 0003-9098

Roth-Maier, D. and Paulicks, B.R. (2003). Aspects for Determining the Requirement of B-Vitamins Vitamine und Zusatzstoffe in der Ernährung von Mensch und Tier, Schubert, R., Flachowsky, G., Jahreis, G., Bitsch, R., Jena/Thüringen, pp. 26-37.

Roth-Maier, D.A., Wild, S.I., Erhardt, W., Henke, J. and Kirchgessner, M. (1999). Investigations on the Intestinal Availability of Native Thiamin in Selected Foods and Feedstuffs. Eur J Nutr 38, 241-246. DOI: $10.1007 / \mathrm{s} 003940050067$

Saki, A.A., Hemati Matin, H.R., Tabatabai, M.M., Zamani, P. and Harsini, R.N. (2010). Microflora Population, Intestinal Condition and Performance of Broilers in Response to Various Rates of Pectin and Cellulose in the Diet. Arch Geflügelk 74, 183-188. ISSN: 0003-9098

Sauvant, D., Perez, J.-M., Tran, G., Bontems, V., Chapoutot, P., Doreau, B., Jeondreville, C., Kaushik, S.J., Lessire, M., Martin-Rosset, W., Meschy, F., Noblet, J., Peyraud, J.-L., Rulquin, H. and Sève, B. (2004). Tables of Composition and Nutritional Value of Feed Materials: Pigs, Poultry, Cattle, Sheep, Goats, Rabbits, Horses and Fish. Wageningen Academic Publishers, INRA, Wageningen \& Paris. ISBN 2-7380-1158-6

Schwechheimer, S.K., Park, E.Y., Revuelta, J.L., Becker, J. and Wittmann, C. (2016). Biotechnology of Riboflavin. Appl Microbiol Biot 100, 2107-2119. DOI: 10.1007/s00253-015-7256-z

Schwediauer, P., Hagmüller, W. and Zollitsch, W. (2017). Germination of Faba Beans (Vicia Faba L.) for Organic Weaning Piglets. Org Agr. DOI: 10.1007/s13165-017-0195-5

Shewry, P.R. (2007). Improving the Protein Content and Composition of Cereal Grain. J Cereal Sci 46, 239250. DOI: $10.1016 / j . j c s .2007 .06 .006$

Shewry, P.R., Piironen, V., Lampi, A.-M., Edelmann, M., Kariluoto, S., Nurmi, T., Fernandez-Orozco, R., Andersson, A.A.M., Åman, P., Fraś, A., Boros, D., Gebruers, K., Dornez, E., Courtin, C.M., Delcour, J.A., Ravel, C., Charmet, G., Rakszegi, M., Bedo, Z. and Ward, J.L. (2010). Effects of Genotype and Environment on the Content and Composition of Phytochemicals and Dietary Fiber Components in Rye in the Healthgrain Diversity Screen. J Agric Food Chem 58, 9372-9383. DOI: 10.1021/jf100053d

Shewry, P.R., Van Schaik, F., Ravel, C., Charmet, G., Rakszegi, M., Bedo, Z. and Ward, J.L. (2011). Genotype and Environment Effects on the Contents of Vitamins B1, B2, B3, and B6 in Wheat Grain. J Agr Food Chem 59, 10564-10571. DOI: 10.1021/jf202762b 
Shurson, G.C., Salzer, T.M., Koehler, D.D. and Whitney, M.H. (2011). Effect of Metal Specific Amino Acid Complexes and Inorganic Trace Minerals on Vitamin Stability in Premixes. Anim Feed Sci Tech 163, 200-206. DOI: 10.1016/j.anifeedsci.2010.11.001

Sibbald, I.R. (1987). Estimation of Bioavailable Amino-Acids in Feedingstuffs for Poultry and Pigs - a Review with Emphasis on Balance Experiments. Can J Anim Sci 67, 221-301. ISSN: 0800-3984

Sierra, I. and Vidal-Valverde, C. (1999). Kinetics of Free and Glycosylated B6 Vitaminers, Thiamin and Riboflavin During Germination of Pea Seeds. J Sci Food Agric 79, 307-310. DOI: 10.1002/(sici)10970010(199902)79:2<307::Aid-jsfa195>3.0.Co;2-z

Sklan, D. and Hurwitz, S. (1980). Protein Digestion and Absorption in Young Chicks and Turkeys. J Nutr 110, 139-144. DOI: 10.1093/jn/110.1.139

Smith, J., Gerrard, C.L. and Hermansen, J.E. (2014). Improved Contribution of Local Feed to Support 100\% Organic Feed Supply to Pigs and Poultry, In: Smith, J., Gerrard, C.L. and Hermansen, J.E. (Eds.), ICOPP.

Spindler, H.K., Mosenthin, R., Rosenfelder, P., Jørgensen, H., Bach Knudsen, K.E., Sauer, N., Htoo, J.K. and Eklund, M. (2016). Standardized lleal Digestibility of Amino Acids in Eight Genotypes of Barley Fed to Growing Pigs. Animal 10, 1931-1940. DOI: 10.1017/S175173111600104X

Stahmann, K.P., Revuelta, J.L. and Seulberger, H. (2000). Three Biotechnical Processes Using Ashbya Gossypii, Candida Famata, or Bacillus Subtilis Compete with Chemical Riboflavin Production. Appl Microbiol Biotechnol 53, 509-516. DOI: 10.1007/s002530051649

Stein, H.H., Fuller, M.F., Moughan, P.J., Sève, B., Mosenthin, R., Jansman, A.J.M., Fernández, J.A. and de Lange, C.F.M. (2007). Definition of Apparent, True, and Standardized Ileal Digestibility of Amino Acids in Pigs. Livest Sci 109, 282-285. DOI 10.1016/j.livsci.2007.01.019

Stein, H.H., Pedersen, C., Wirt, A.R. and Bohlke, R.A. (2005). Additivity of Values for Apparent and Standardized Ileal Digestibility of Amino Acids in Mixed Diets Fed to Growing Pigs. J Anim Sci 83, 2387-2395. DOI: $10.2527 / 2005.83102387 x$

Stockdale, E.A., Shepherd, M.A., Fortune, S. and Cuttle, S.P. (2006). Soil Fertility in Organic Farming Systems - Fundamentally Different? Soil Use Manage 18, 301-308. DOI: 10.1111/j.1475-2743.2002.tb00272.x

Strobel, W., Ahrens, F., Hartmann, G., Kluge, H. and Jeroch, H. (2001). Gehalt an Inhaltsstoffen von Weizen, Roggen und Hafer bei Anbau unter konventionellen und den Bedingungen des Ökologischen Landbaus [Contents Ofsubstances in Wheat, Rye and Oats at Cultivation under Conventional and the Conditions of Organic Farming]. Bodenkultur 52.

Sujak, A., Kotlarz, A. and Strobel, W. (2006). Compositional and Nutritional Evaluation of Several Lupin Seeds. Food Chem 98, 711-719. DOI 10.1016/j.foodchem.2005.06.036

Urbano, G., López-Jurado, M., Frejnagel, S., Gómez-Villalva, E., Porres, J.M., Frías, J., Vidal-Valverde, C. and Aranda, P. (2005). Nutritional Assessment of Raw and Germinated Pea (Pisum Sativum L.) Protein and Carbohydrate by in Vitro and in Vivo Techniques. Nutrition 21, 230-239. DOI: 10.1016/j.nut.2004.04.025

USDA (2016). Usda National Nutrient Database for Standard Reference, Release 28, Version Current: September 2015, Slightly Revised May 2016, US Department of Agriculture, Agricultural Research Service, Nutrient Data Laboratory.

USDA (2018). Usda National Nutrient Database for Standard Reference, Release 1 April 2018, Software V.3.9.5 2018-08-15, US Department of Agriculture, Agricultural Research Service, Nutrient Data Laboratory.

Van Krimpen, M.M., Kwakkel, R.P., Reuvekamp, B.F.J., Van Der Peet-Schwering, C.M.C., Den Hartog, L.A. and Verstegen, M.W.A. (2005). Impact of Feeding Management on Feather Pecking in Laying Hens. World Poult Sci J 61, 663-686. DOI:10.1079/WPS200478

Watson, C.A., Atkinson, D., Gosling, P., Jackson, L.R. and Rayns, F.W. (2006). Managing Soil Fertility in Organic Farming Systems. Soil Use Manage 18, 239-247. DOI: 10.1111/j.1475-2743.2002.tb00265.x

Weißmann, F., Reichenbach, H.-W., Schoen, A. and Ebert, U. (2005). Aspekte der Mast- und Schlachtleistung sowie Wirtschaftlichkeit von Schweinen bei $100 \%$ Biofütterung [Aspects of Fattening, Carcass, and Meat Performance as Well as Economy of $100 \%$ Organically Fattened Pigs], In: Heß, J. and Rahmann, G. (Eds.), Ende der Nische Beiträge zur 8. Wissenschaftstagung Ökologischer Landbau, Kassel University Press $\mathrm{GmbH}$, Kassel.

Winter, C.K. and Davis, S.F. (2006). Organic Foods. J Food Sci 71. DOI: 10.1111/j.1750-3841.2006.00196.x

Wolfson, J.L. and Shearer, G. (1981). Amino Acid Composition of Grain Protein of Maize Grown with and without Pesticides and Standard Commercial Fertilizers. Agron J 73, 611-613. DOI: 10.2134/agronj1981.00021962007300040010x

Worthington, V. (2001). Nutritional Quality of Organic Versus Conventional Fruits, Vegetables, and Grains. J Altern Complem Med 7, 161-173. DOI: 10.1089/107555301750164244 
Zeltner, E. and Maurer, V. (2009). Welfare of Organic Poultry, Poultry Welfare Symposium, Cervia, Italy, pp. 104-112.

Zuber, T., Maurer, H.P., Möhring, J., Nautscher, N., Siegert, W., Rosenfelder, P. and Rodehutscord, M. (2016a). Variability in Amino Acid Digestibility of Triticale Grain from Diverse Genotypes as Studied in Cecectomized Laying Hens. Poult Sci 95, 2861-2870. DOI: 10.3382/ps/pew174 


\section{Appendix}

\section{Chapter I}

Table A I: $F$ - and p-values (in italics) of main factors in models describing varietal and environmental impact on the contents of ether extract (EE), crude ash (CA), crude fibre (CF), nitrogen-free extracts (NfE) and starch of selected cultivars

Table A I 2: $\quad F$ - and p-values (in italics) of main factors in models describing varietal and environmental impact on the contents of crude protein and amino acids of selected cultivars

Table A I 3: $\quad F$ - and p-values (in italics) of main factors in models describing varietal and environmental impact on the contents of crude protein and amino acids of selected cultivars

Table A I 4: $\mathrm{F}$ - and $\mathrm{p}$-values (in italics) of main factors in models describing varietal and environmental impact on the contents of amino acids of selected cultivars.

Table A I 5: F- and p-values (in italics) of main factors in models describing varietal and environmental impact on the contents of amino acids of selected cultivars.

Table A I 6: Crude nutrient contents (LSMean and SE in \% DM) of winter wheat samples (Triticum aestivum L.) from different varieties, years, and areas.

Table A I 7: Crude nutrient contents (LSMean and SE in \% DM) of spring wheat samples (Triticum aestivum L.) from different varieties, years, and areas.

Table A I 8: Crude nutrient contents (LSMean and SE in \% DM) of winter rye samples (Secale cereale L.) from different varieties, years, and sites .. 163

Table A I 9: Crude nutrient contents (LSMean and SE in \% DM) of winter triticale samples (Triticosecale) from different varieties, years, and areas .....

Table A I 10: Crude nutrient contents (LSMean and SE in \% DM) of winter barley samples (Hordeum vulgare L.) from different varieties, years, and sites 164

Table A I 11: Crude nutrient contents (LSMean and SE in \% DM) of spring barley samples (Hordeum vulgare L.) from different varieties, years, and areas. 
Table A I 12: Crude nutrient contents (LSMean and SE in \% DM) of oat samples (Avena sativa L.) from different varieties, years, and sites 165

Table A I13: Crude nutrient contents (LSMean and SE in \% DM) of field pea samples (Pisum sativum, L.) from different varieties, years, and areas. 165

Table A I 14: Crude nutrient contents (LSMean and SE in \% DM) of field bean samples (Vicia faba L.) from different varieties, years, and areas 166

Table A 15: Crude nutrient contents (LSMean and SE in \% DM) of blue lupin samples (Lupinus angustifolius L.) from different varieties, years, and areas.

Table A I 16: Amino acid contents (LSMean and SE in $\mathrm{g} / \mathrm{kg} \mathrm{DM}$ ) of winter wheat samples (Triticum aestivum L.) from different varieties, years, and areas

Table A I 17: Amino acid contents (LSMean and SE in $\mathrm{g} / \mathrm{kg} \mathrm{DM}$ ) of spring wheat samples (Triticum aestivum L.) from different varieties, years, and areas

Table A I 18: Amino acid contents (LSMean and SE in $\mathrm{g} / \mathrm{kg} \mathrm{DM}$ ) of winter rye samples (Secale cereale L.) from different varieties, years, and sites... 169

Table A I 19: Amino acid contents (LSMean and SE in $\mathrm{g} / \mathrm{kg} \mathrm{DM}$ ) of winter triticale samples (Triticosecale) from different varieties, years, and areas 170

Table A I20: Amino acid contents (LSMean and SE in $\mathrm{g} / \mathrm{kg} \mathrm{DM}$ ) of winter barley samples (Hordeum vulgare L.) from different varieties, years, and sites

Table A I 21: Amino acid contents (LSMean and SE in $\mathrm{g} / \mathrm{kg} \mathrm{DM}$ ) of spring barley samples (Hordeum vulgare L.) from different varieties, years, and areas

Table A I22: Amino acid contents (LSMean and SE in $\mathrm{g} / \mathrm{kg} \mathrm{DM}$ ) of oat samples (Avena sativa L.) from different varieties, years, and sites

Table A I 23: Amino acid contents (LSMean and SE in $\mathrm{g} / \mathrm{kg} \mathrm{DM}$ ) of field pea samples (Pisum sativum, L.) from different varieties, years, and areas.

Table A I24: Amino acid contents (LSMean and SE in $\mathrm{g} / \mathrm{kg} \mathrm{DM}$ ) of field bean samples (Vicia faba L.) from different varieties, years, and areas ......... 175

Table A I25: Amino acid contents (LSMean and SE in $\mathrm{g} / \mathrm{kg} \mathrm{DM}$ ) of blue lupin samples (Lupinus angustifolius L.) from different varieties, years, and areas ...... 


\section{Chapter IV}

Table A IV 1: In vitro crude protein digestibility coefficients (LSMeans and SE) exemplary for 21-day old broiler chicken in selected cultivars from different harvest years and sites or areas ${ }^{1}$

\section{Chapter V}

Table A V 1: Contents of thiamine and riboflavin in selected cereals and grain legumes [mg/kg DM]

Table A V 2: Maximum differences of thiamine and riboflavin contents between factor manifestations of cereals and grain legumes [mg/kg DM] absolute as well as relative to mean content

Table A V 3: Thiamine and riboflavin contents (LSMean and SE) of winter wheat samples (Triticum aestivum L.) from different varieties, harvest years, and harvest areas in $\mathrm{mg} / \mathrm{kg} \mathrm{DM}$.

Table A V 4: Thiamine and riboflavin contents (LSMean and SE) of spring wheat samples (Triticum aestivum L.) from different varieties, harvest years, and harvest areas in $\mathrm{mg} / \mathrm{kg} \mathrm{DM}$.

Table A V 5: Thiamine and riboflavin contents (LSMean and SE) of winter rye samples (Secale cereale L.) from different varieties, harvest years, and harvest sites in $\mathrm{mg} / \mathrm{kg} \mathrm{DM}$

Table A V 6: Thiamine and riboflavin contents (LSMean and SE) of winter triticale samples (Triticosecale) from different varieties, harvest years, and harvest areas in $\mathrm{mg} / \mathrm{kg} \mathrm{DM}$

Table A V 7: Thiamine and riboflavin contents (LSMean and SE) of winter barley samples (Hordeum vulgare L.) from different harvest sites in $\mathrm{mg} / \mathrm{kg}$ DM 180

Table A V 8: Thiamine and riboflavin contents (LSMean and SE) of spring barley samples (Hordeum vulgare L.) from different varieties, harvest years, and harvest areas in $\mathrm{mg} / \mathrm{kg} \mathrm{DM}$.

Table A V 9: Thiamine and riboflavin contents (LSMean and SE) of oat samples (Avena sativa L.) from different varieties, harvest years, and harvest sites in $\mathrm{mg} / \mathrm{kg} \mathrm{DM}$.

Table A V 10: Thiamine and riboflavin contents (LSMean and SE) of field pea samples (Pisum sativum L.) from different varieties, harvest years, and harvest sites in $\mathrm{mg} / \mathrm{kg} \mathrm{DM}$ 
Table A V 11: Thiamine and riboflavin contents (LSMean and SE) of field bean samples (Vicia faba L.) from different varieties, harvest years, and harvest areas in $\mathrm{mg} / \mathrm{kg} \mathrm{DM}$.

Table A V 12: Thiamine and riboflavin contents (LSMean and SE) of blue lupin samples (Lupinus angustifolius L.) from different varieties, harvest years, and harvest areas in $\mathrm{mg} / \mathrm{kg} \mathrm{DM}$

\section{Chapter I, IV, and V}

Figure A 1: Organic agricultural production areas with homogenous climatic conditions used in the present study; adapted from JKI (2018)....

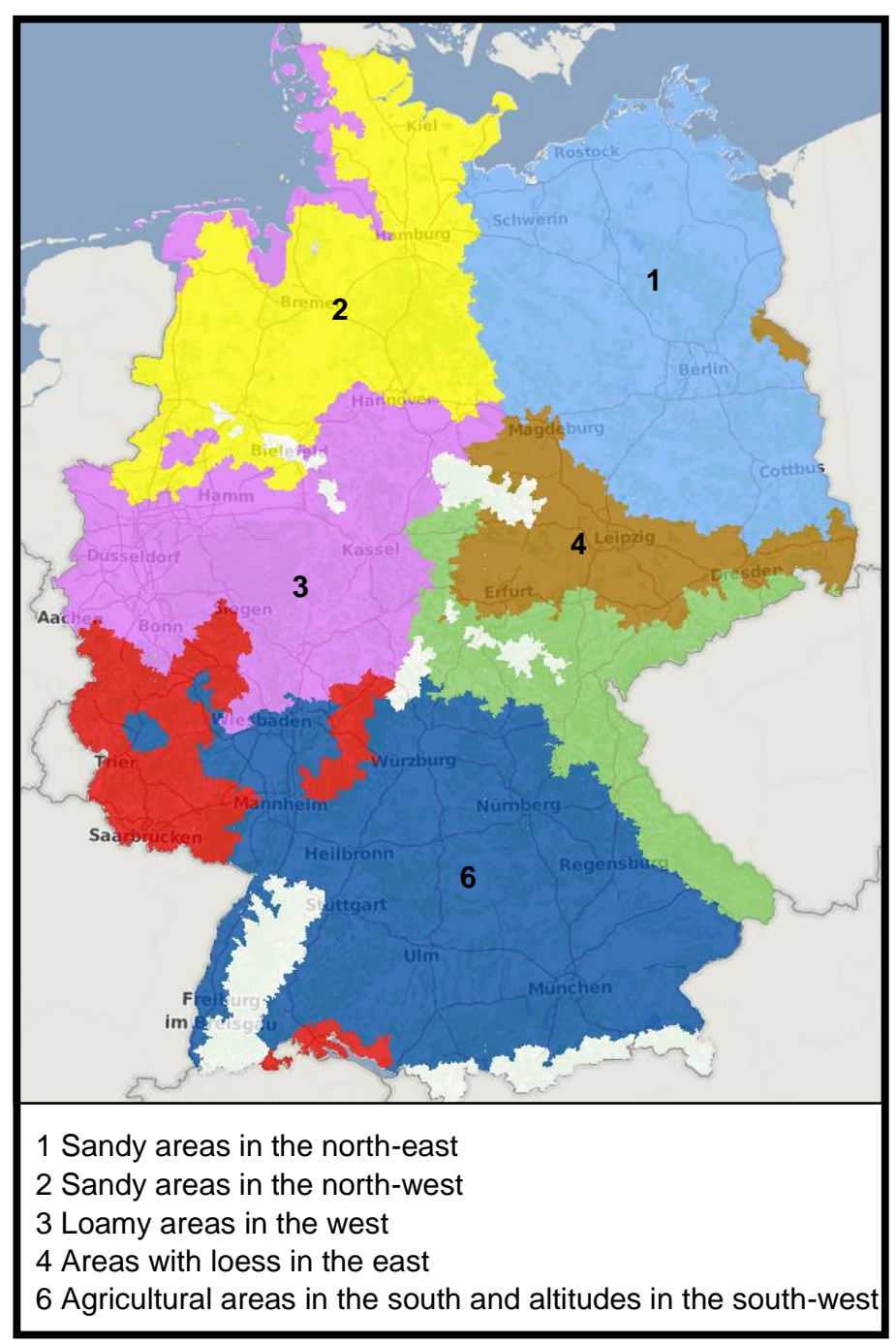

Figure A 1: Organic agricultural production areas with homogenous climatic conditions used in the present study; adapted from JKI (2018) 


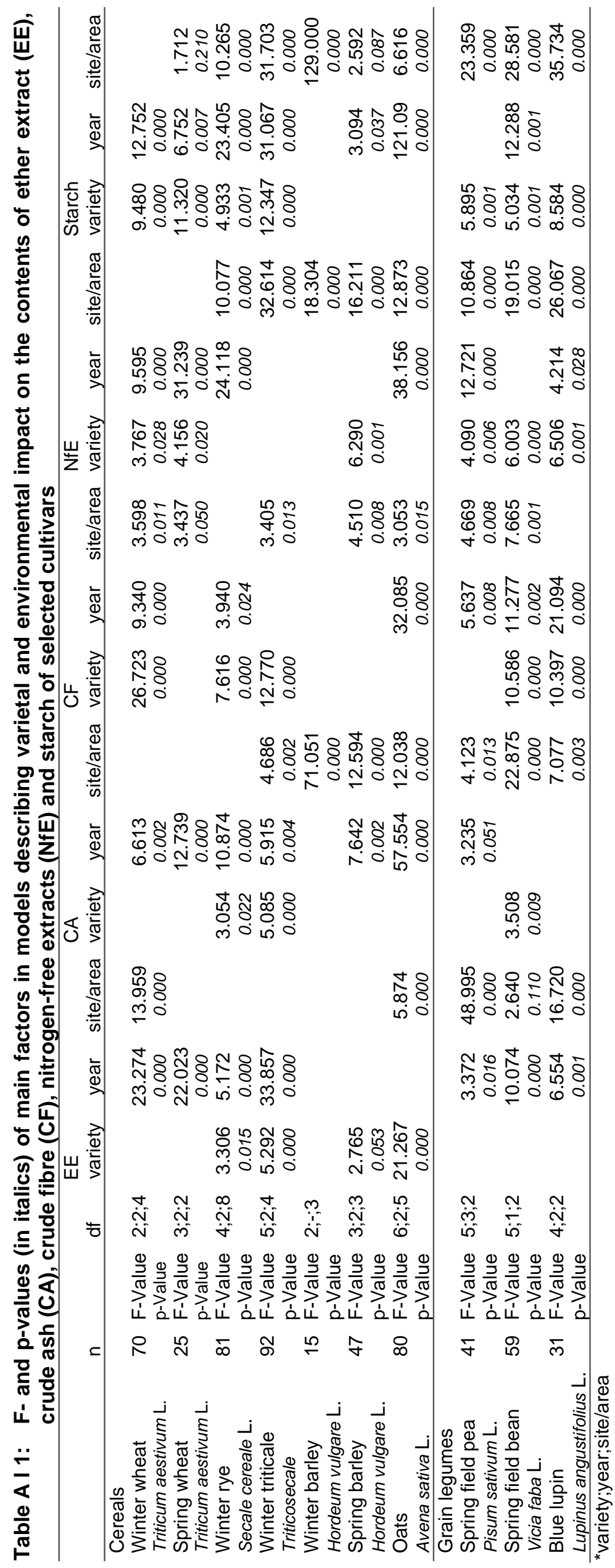




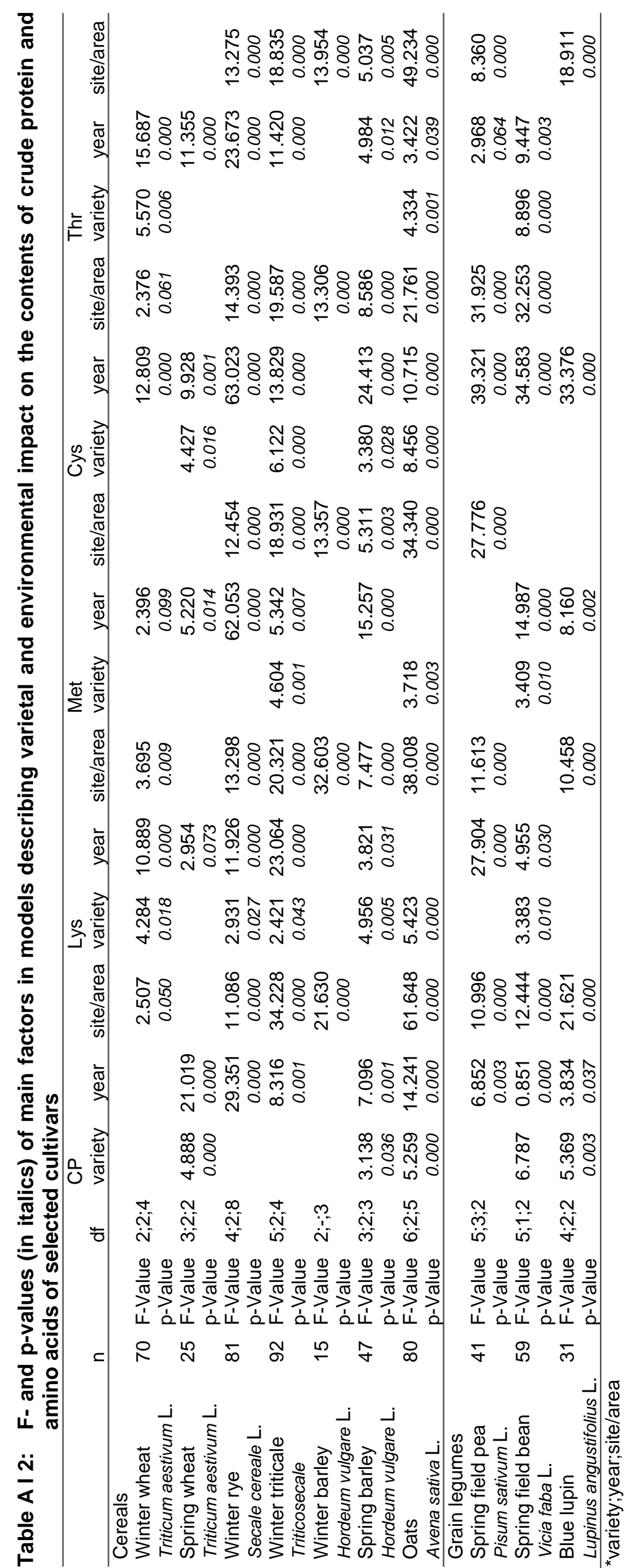




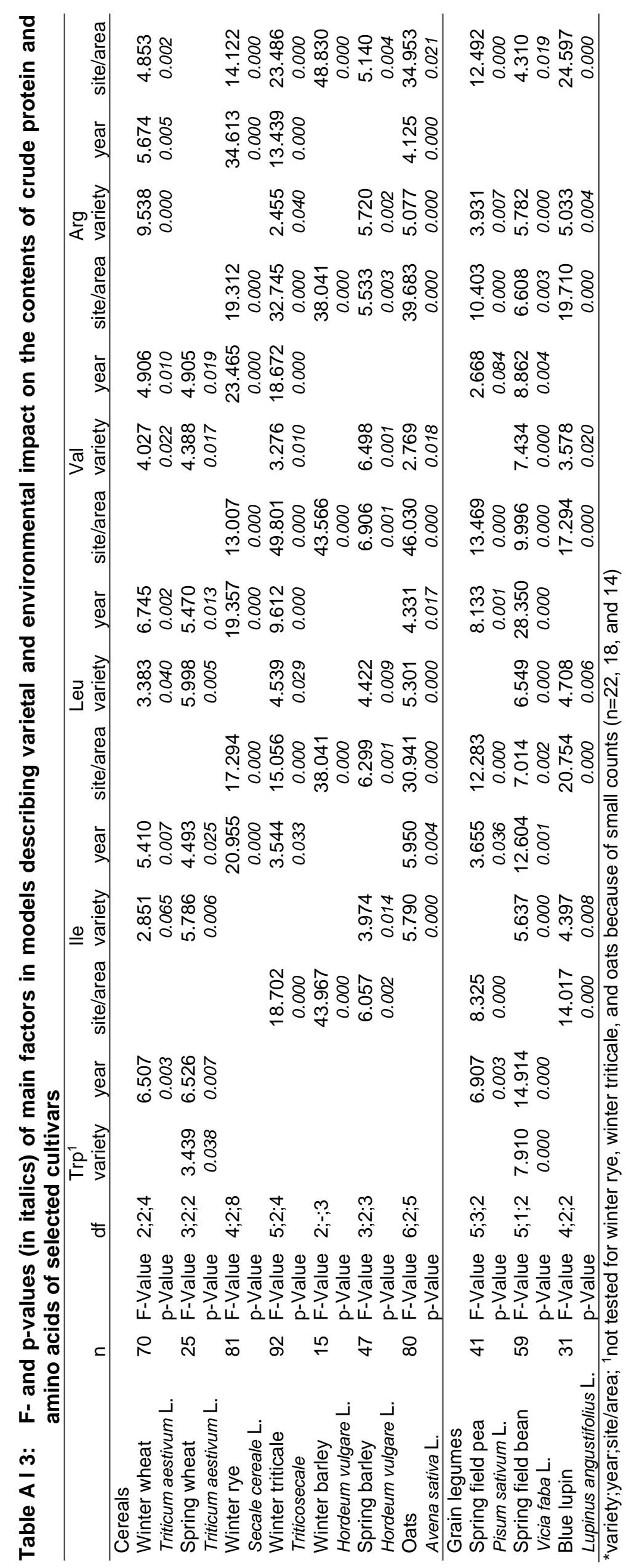




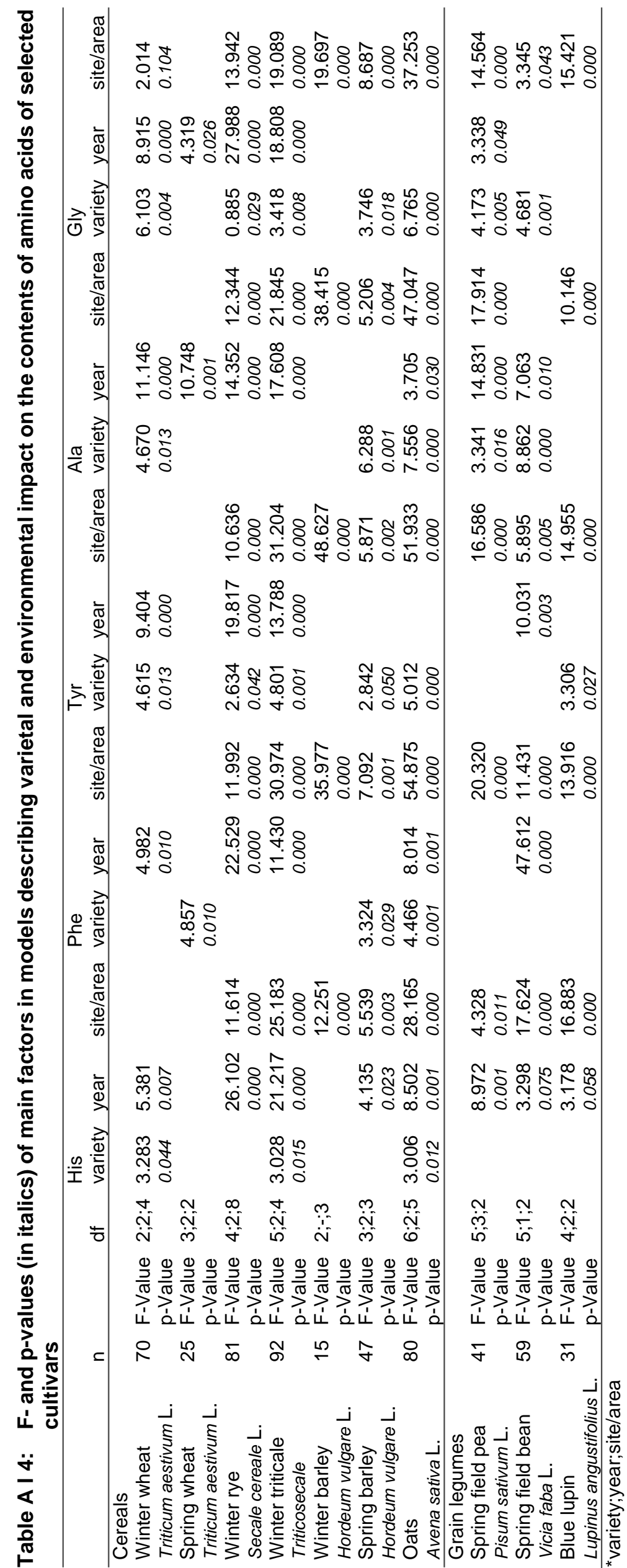




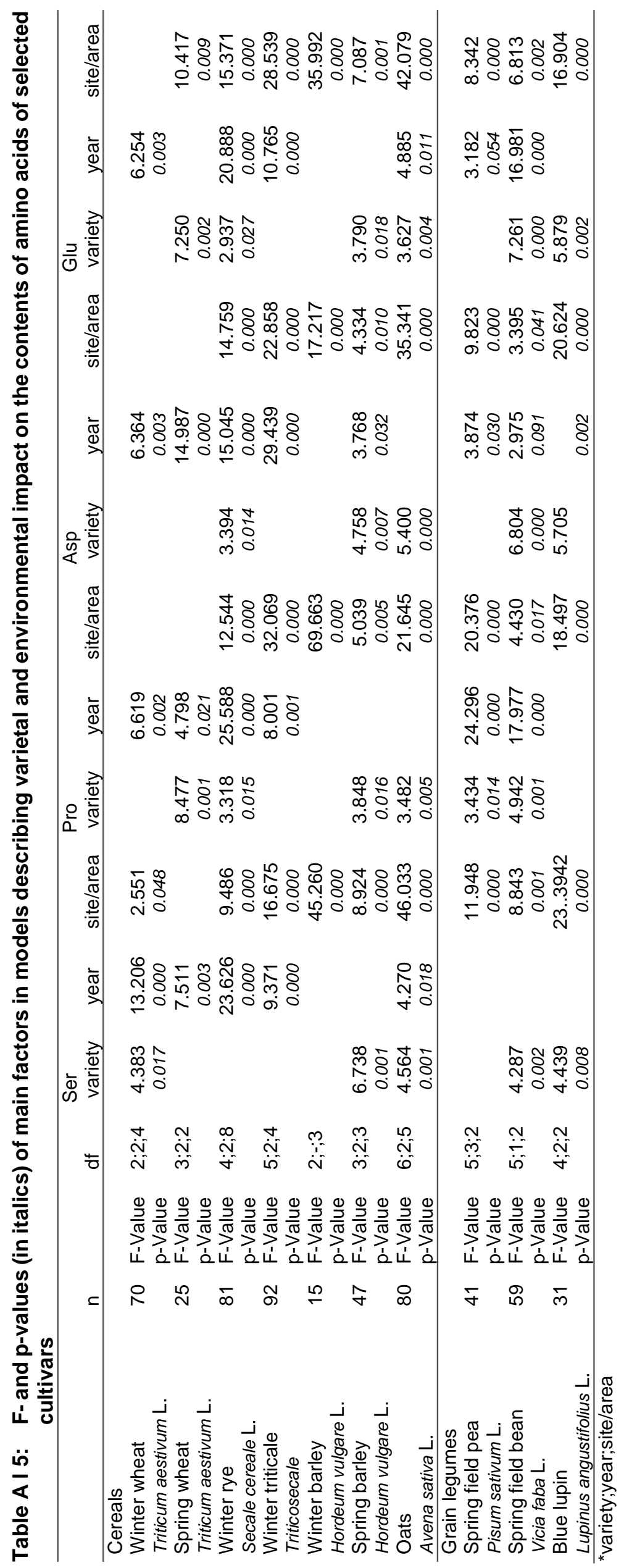




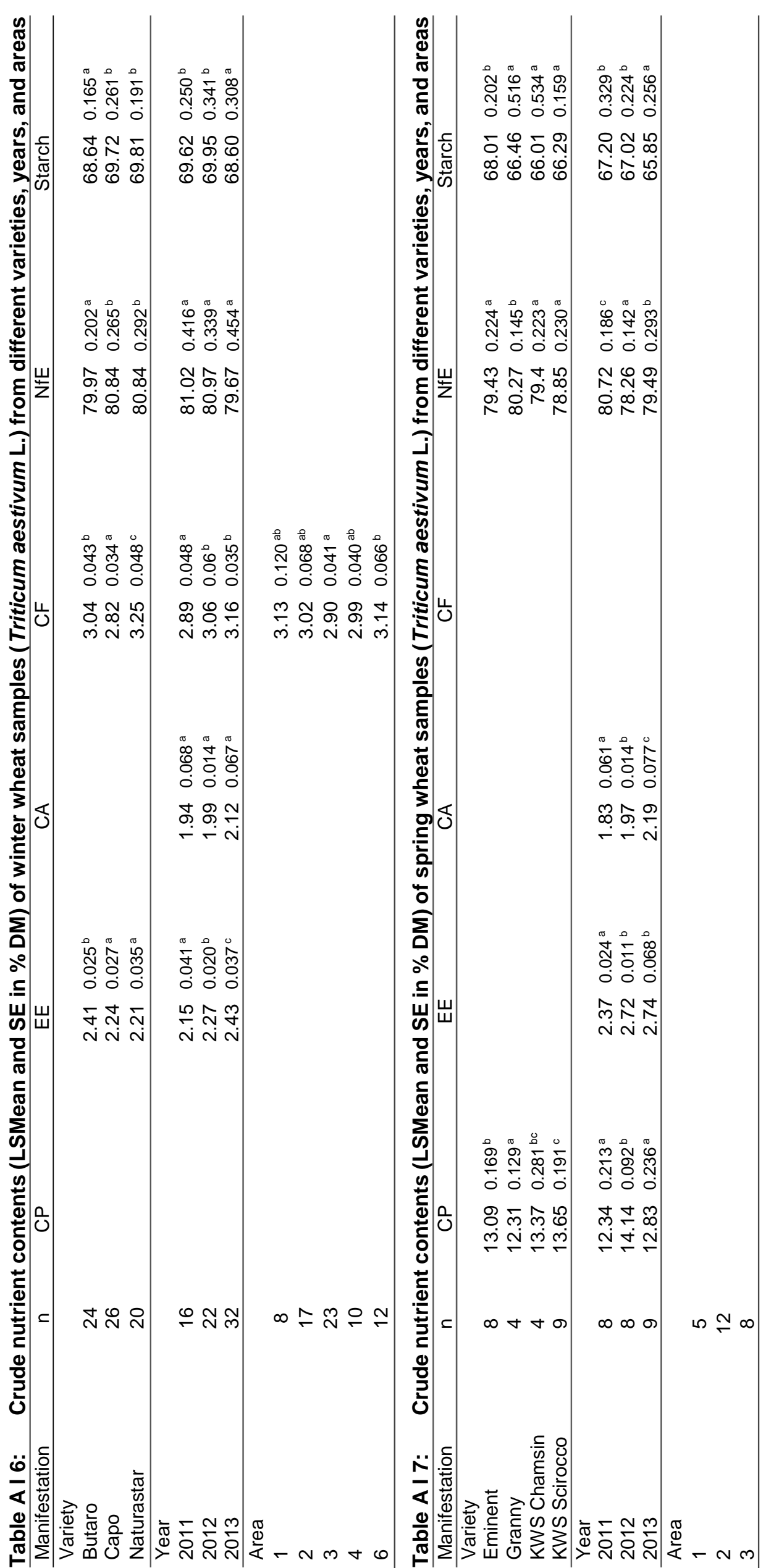




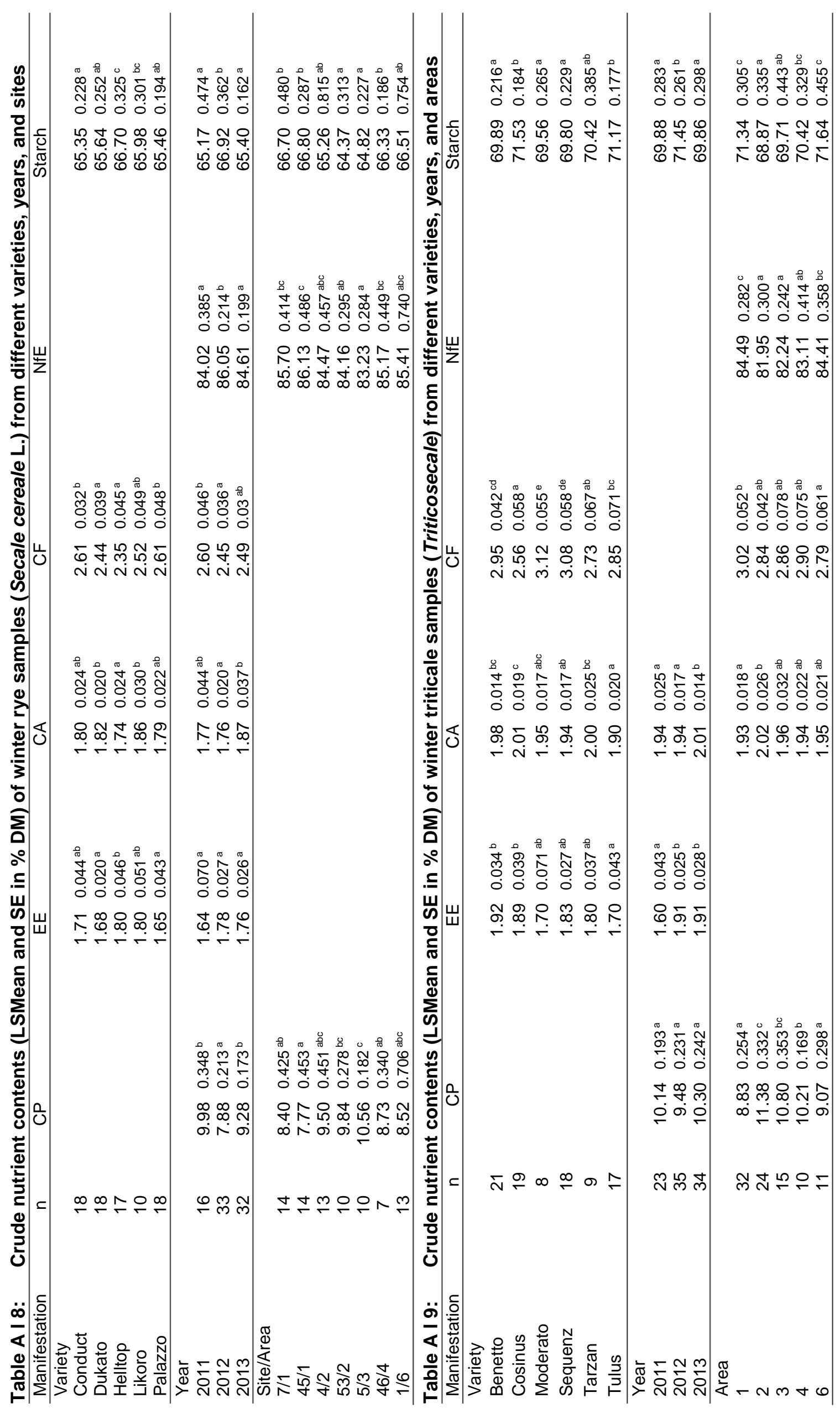




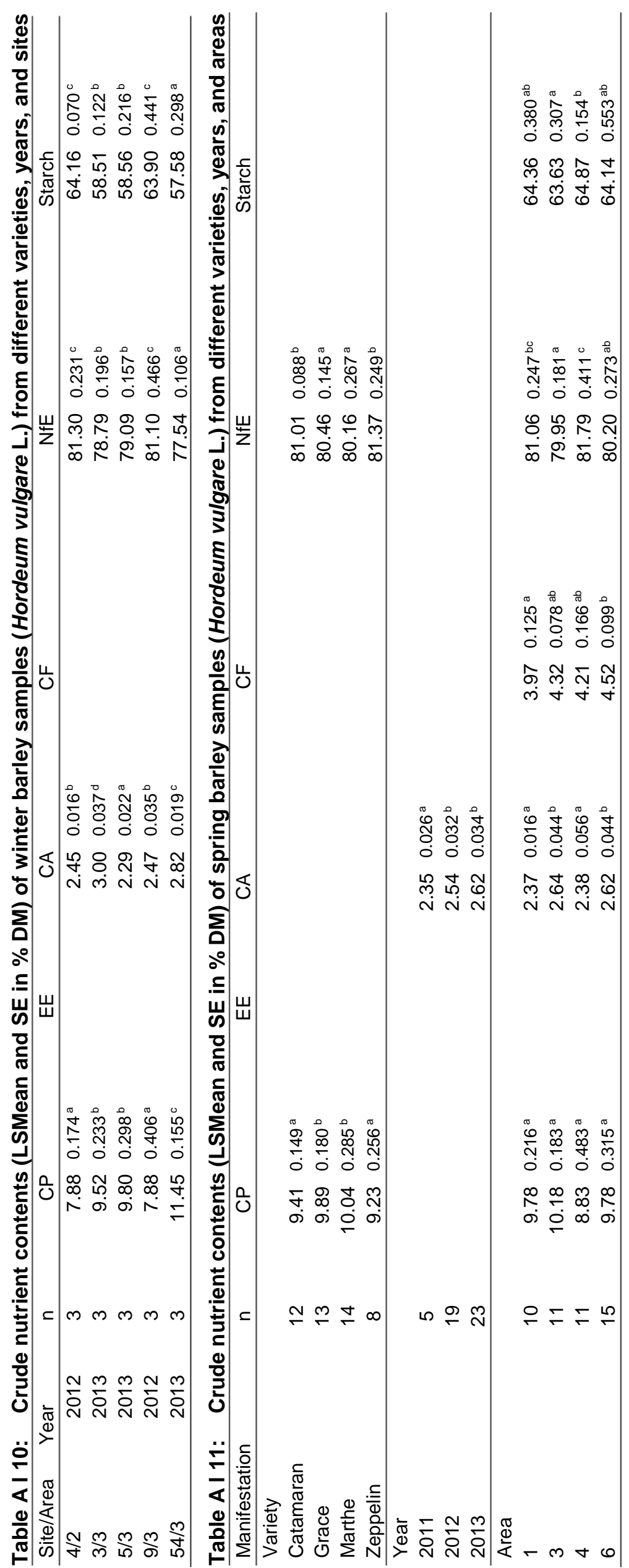




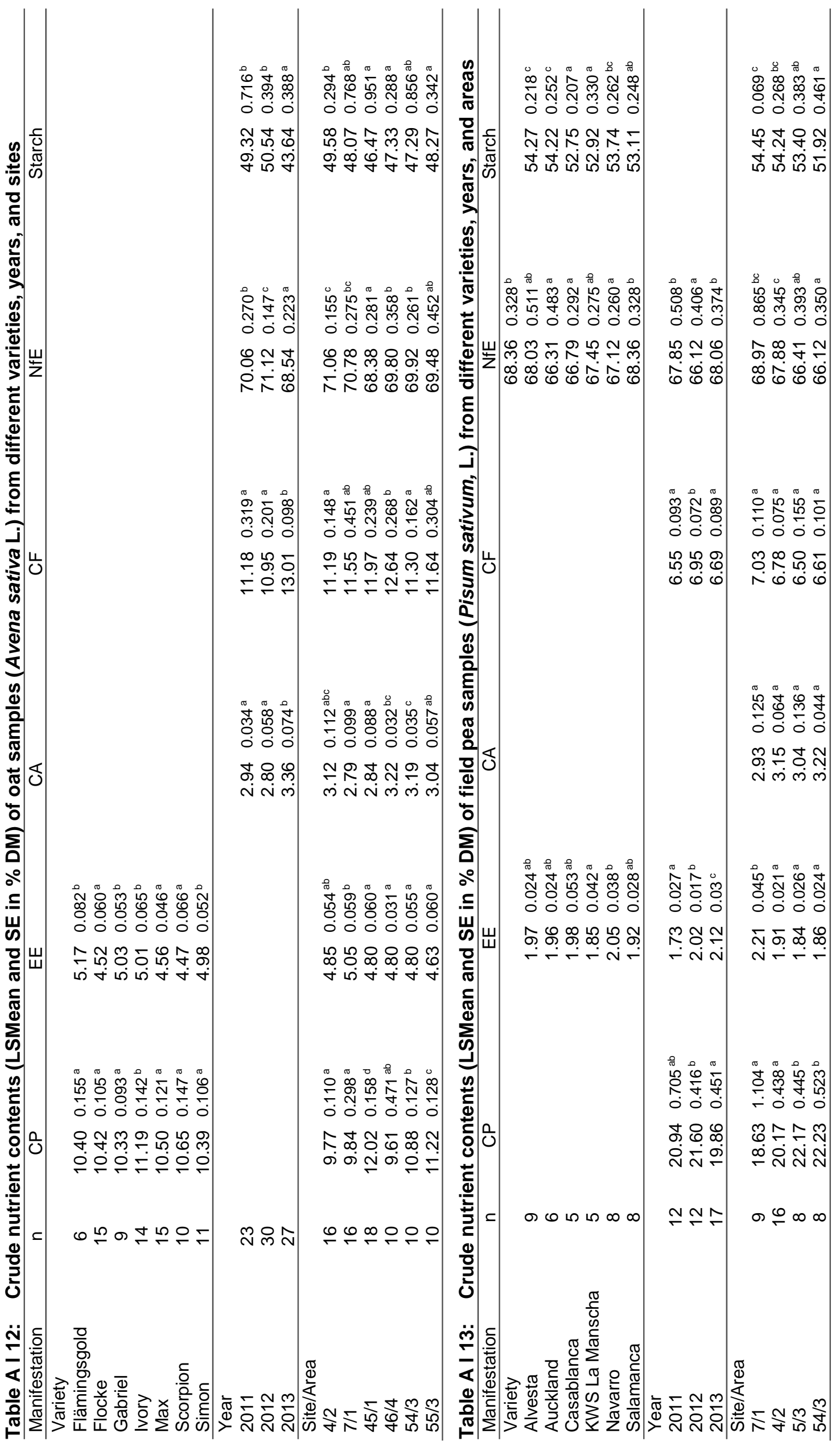




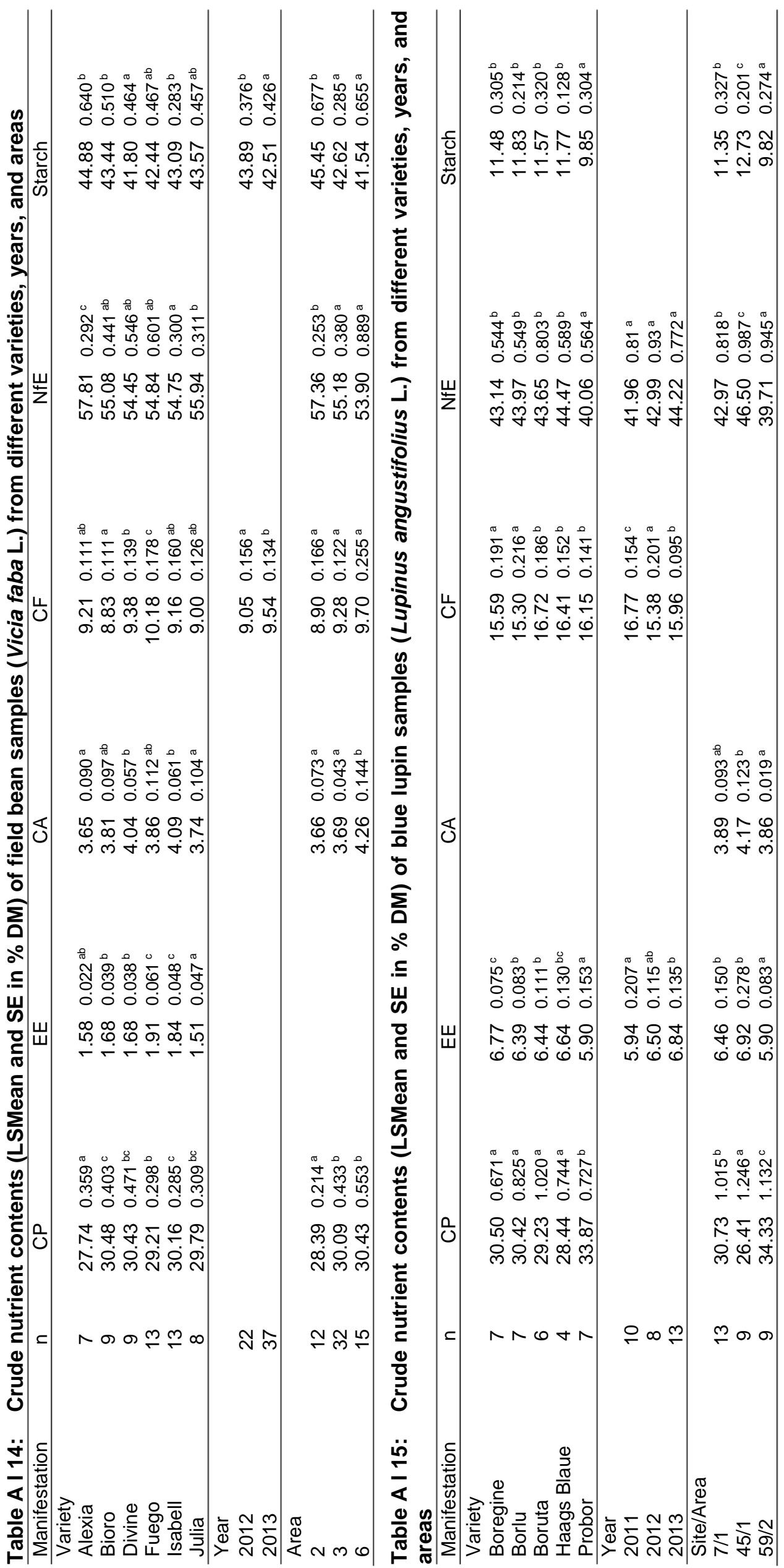




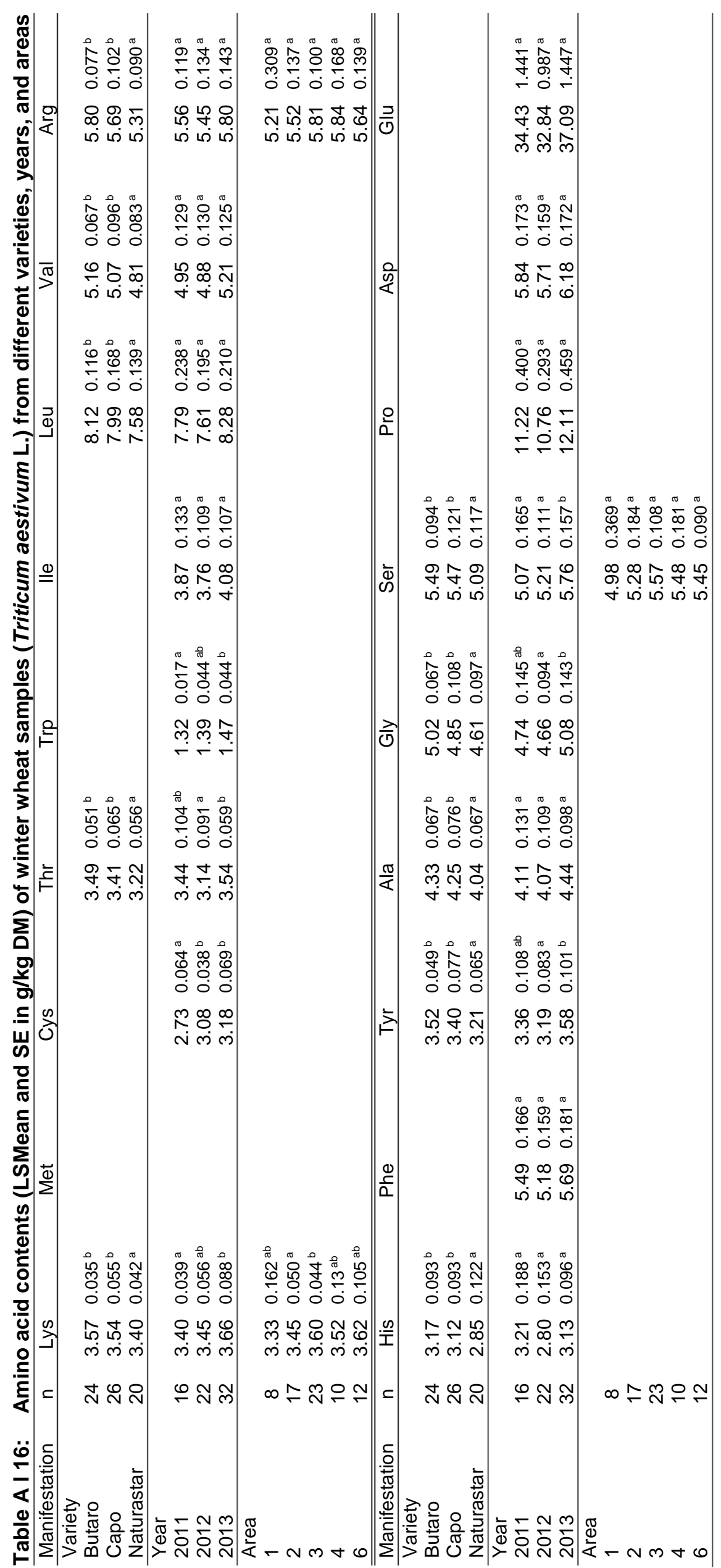




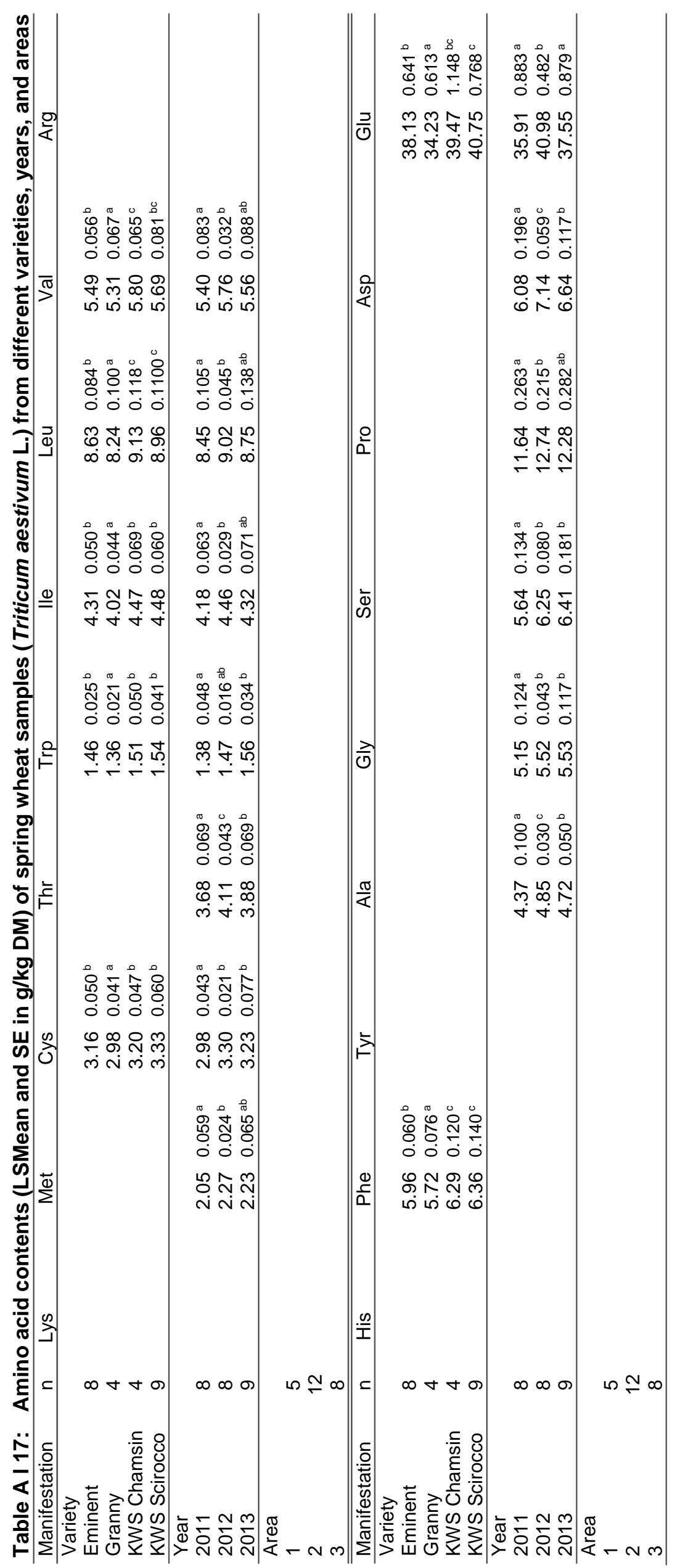




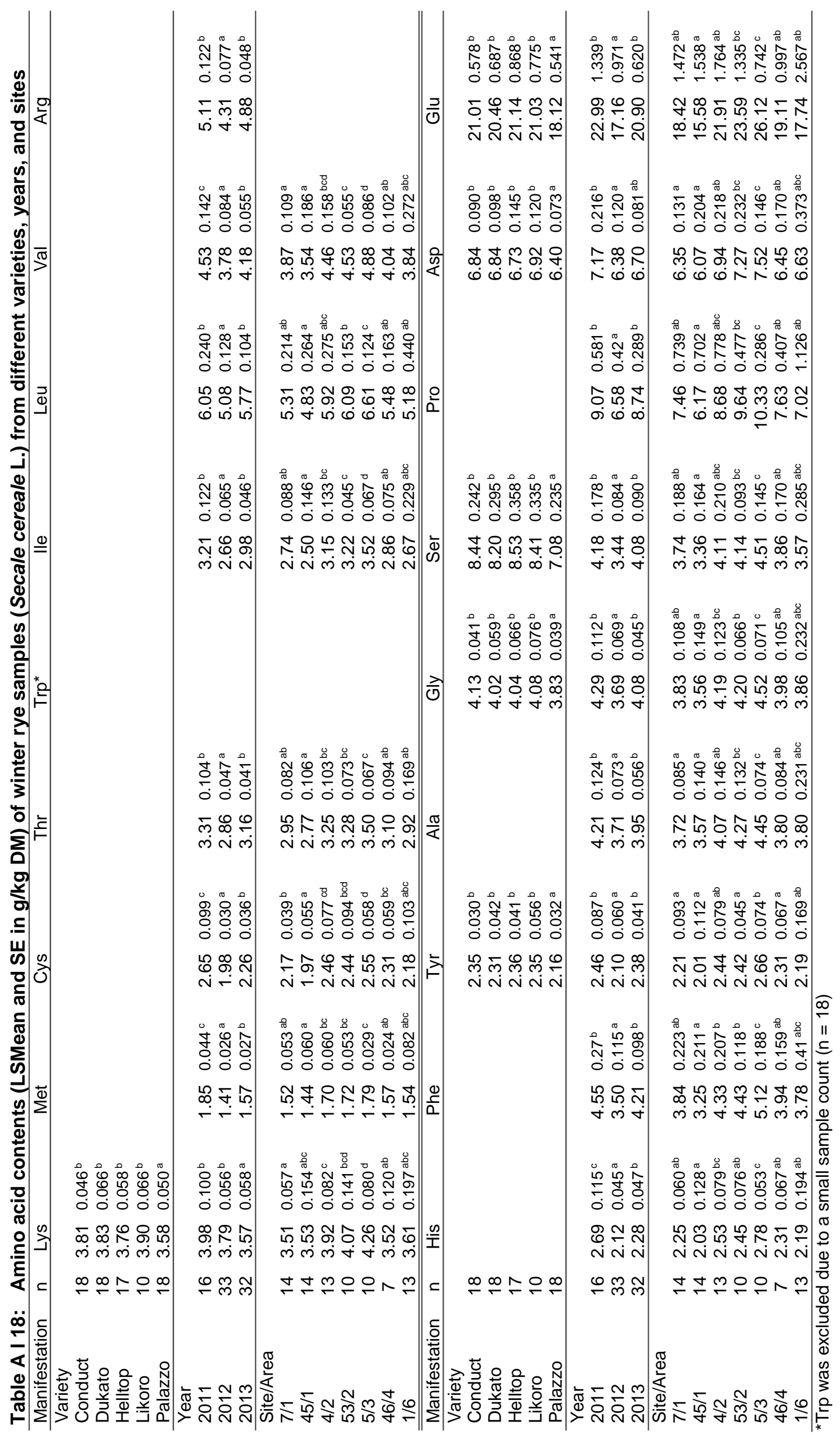




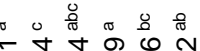

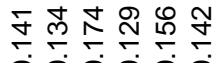

둥형ㄷㅇㅇㅎㅇ

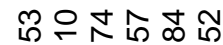

ชั

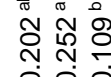

(1)

ơ

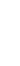

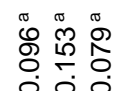

꿍스

लाल

हूँ

용

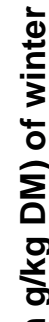

崩

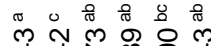

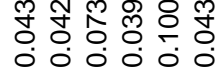

ํํํํํำ

กั่ง ำ

完

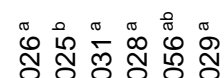

○० 0.0000

๙ิ ๗ ஜ

-

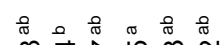

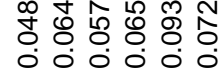

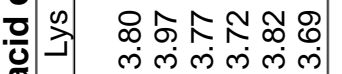

을

दे ᄃ

\section{ö}

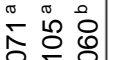

००

두도은

लं ले

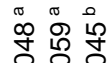

잉ㅇ.

으료묘

ก

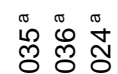

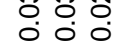

下Øำ

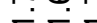

$\begin{array}{ccc}\pi & 0 & 0 \\ 0 & \infty & 0 \\ 0 & \infty & 0 \\ 0 & 0 & 0 \\ 0 & 0 & 0\end{array}$

¿००

소늉용

लं लं

๗ॅू लै

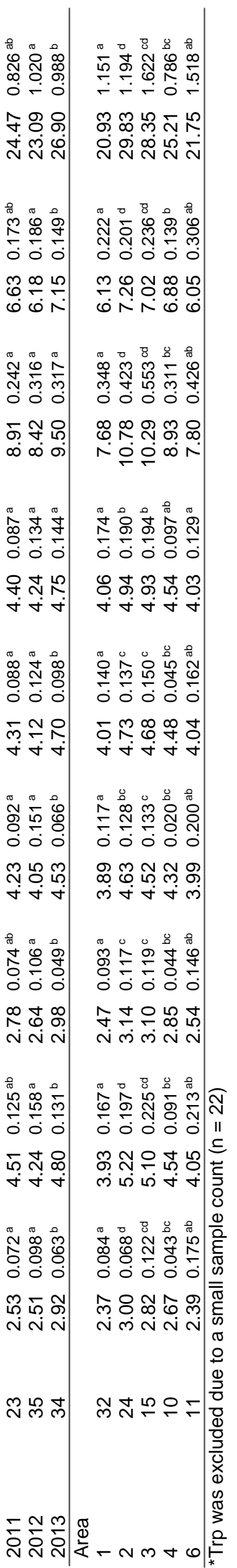

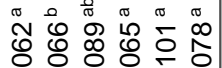
000000

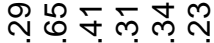

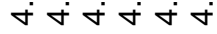

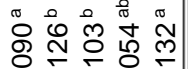

움웅ㅇ

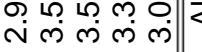

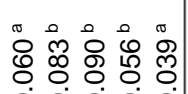

00000

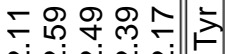

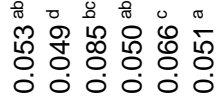

종유요용

ก

『ొ

$\circ 0000$

인

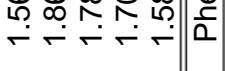

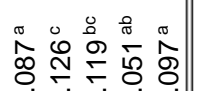

O둥ㄷㅇ

மํㄷㄴㅇำ

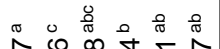

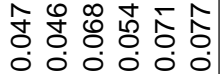

लं में ले

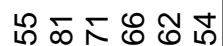

ก ก่ กั่

뜨윤ㅁㅇㅇㄷㄷ

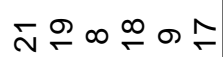

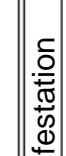

ํํㅇ 이

$0 \div 0$

₹용요

స N

กำ

○ं 0 잉

ஜำ 느

06

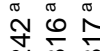

N m

бั 융

$\infty \infty$

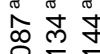

०००

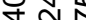

然

00

ल능

(a)

$\wedge \stackrel{\infty}{\infty} \stackrel{0}{0}$

กุ

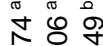

웅.

œ छे

N N

空

○० 0

印市

ナ

$\approx 0$

잉잉

ก๊ ธ ธ

ง N

ํํ

ले ल 


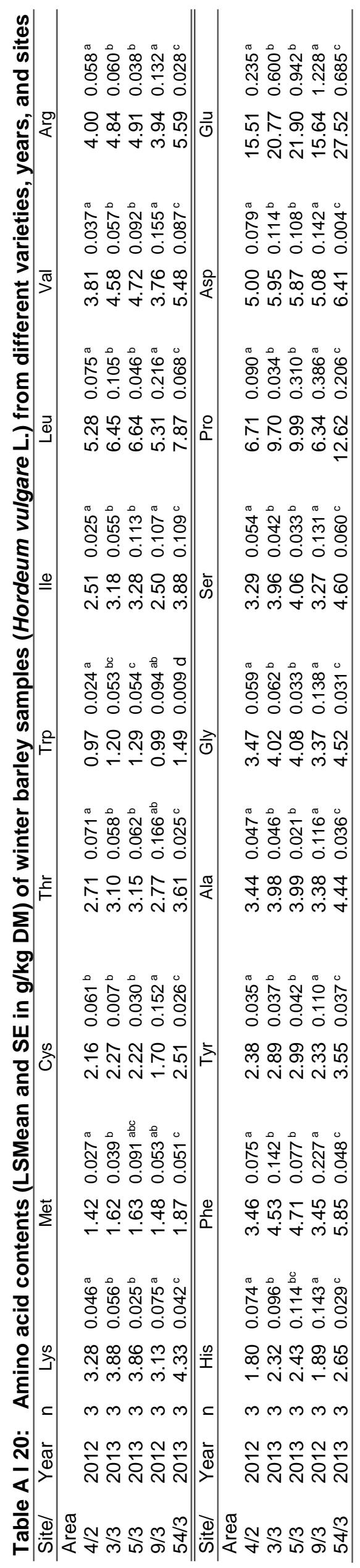




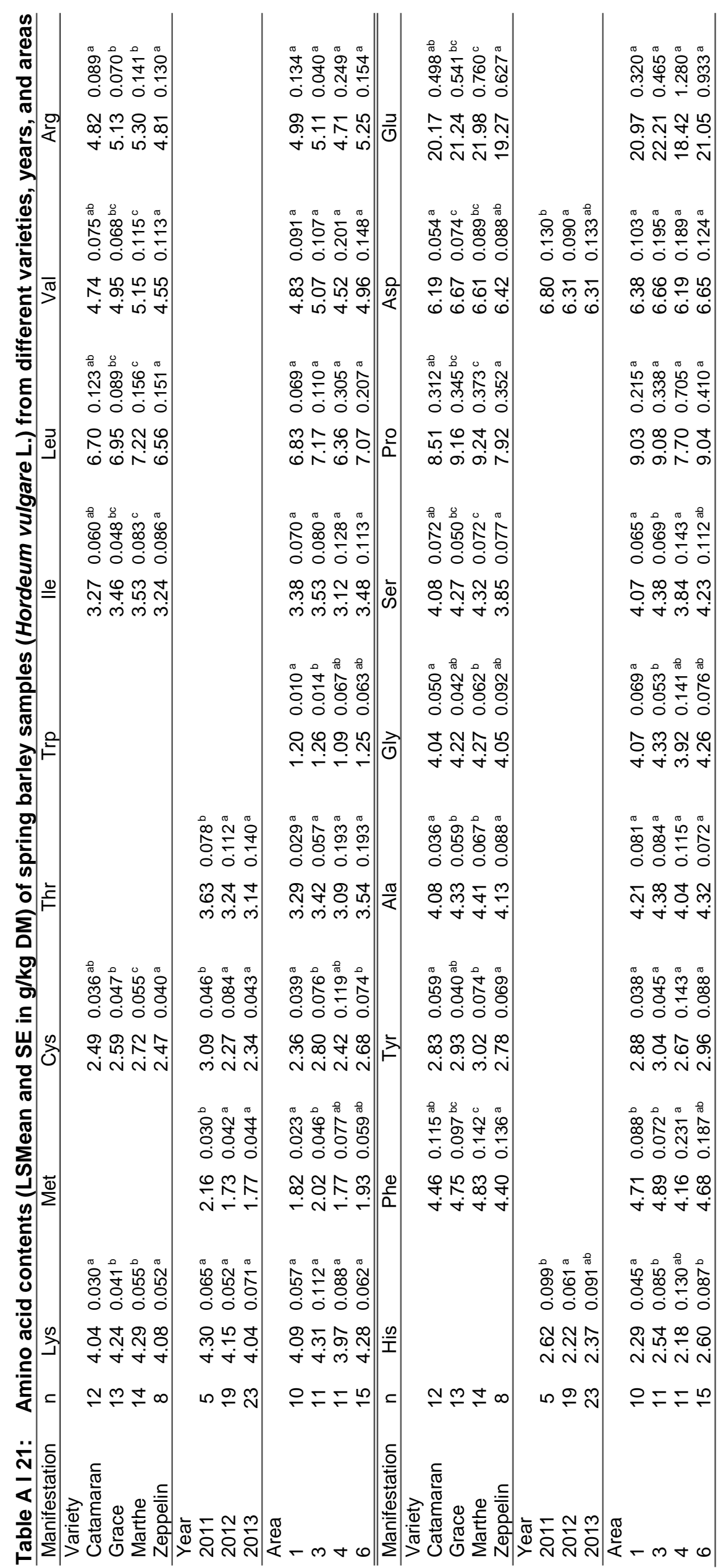




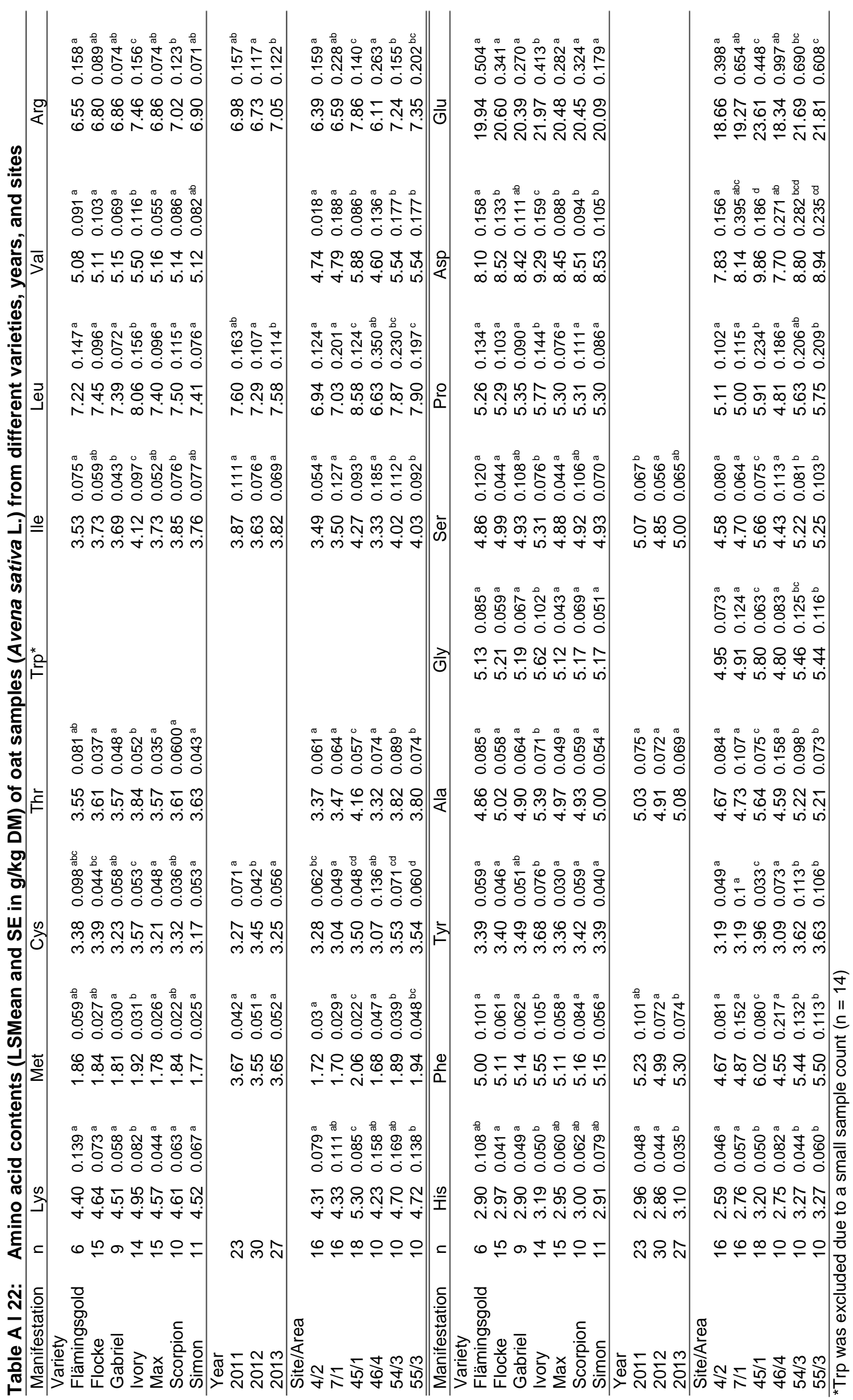




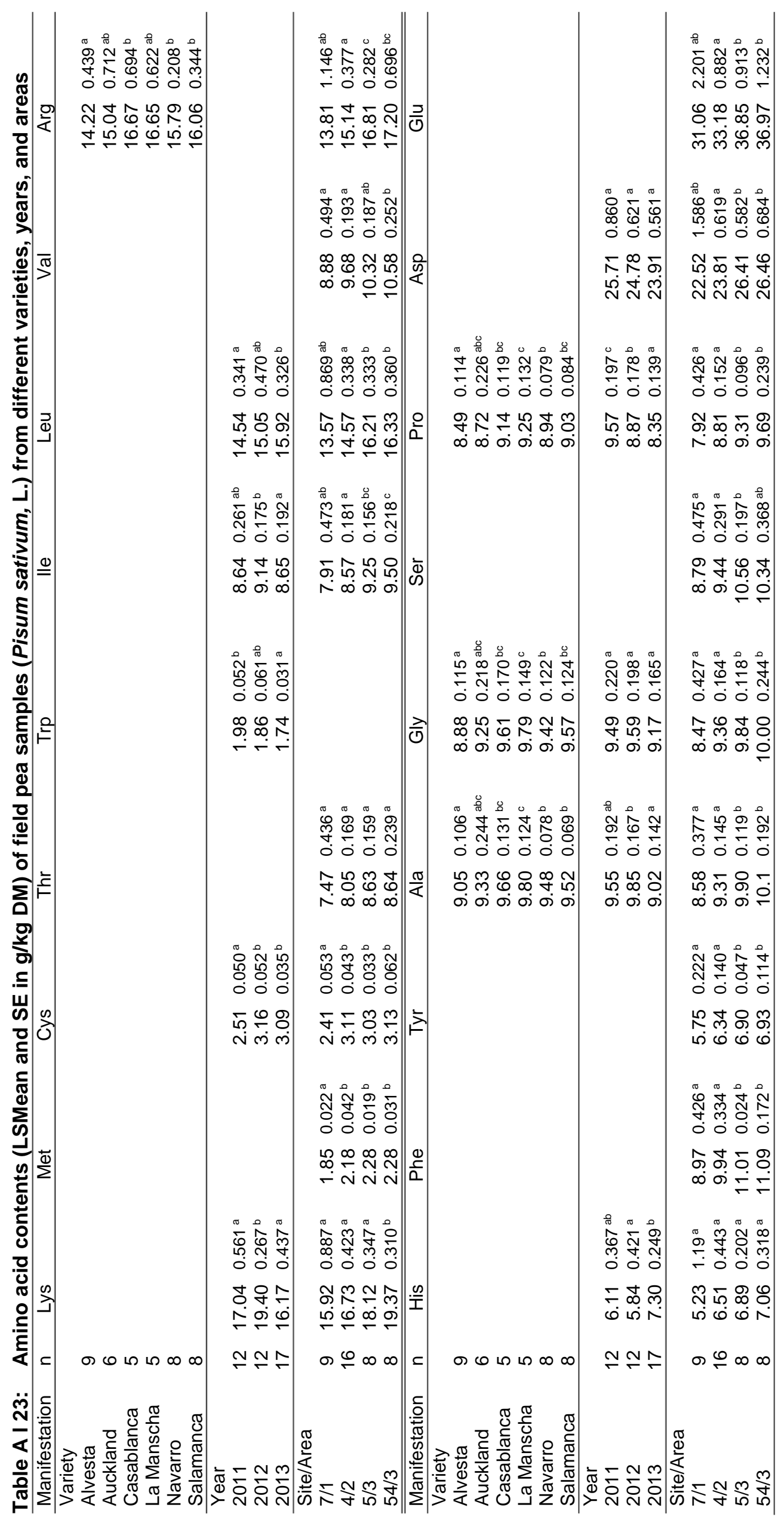




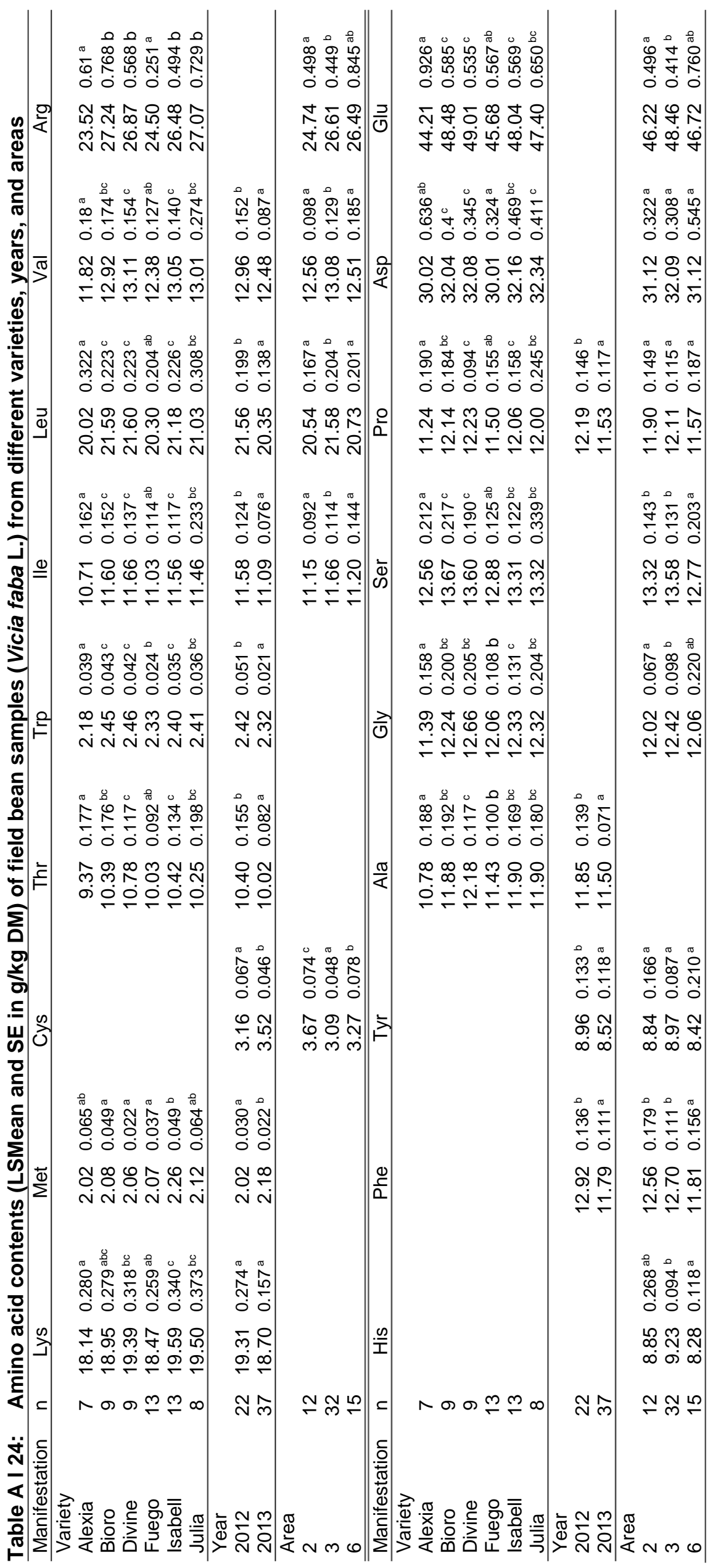




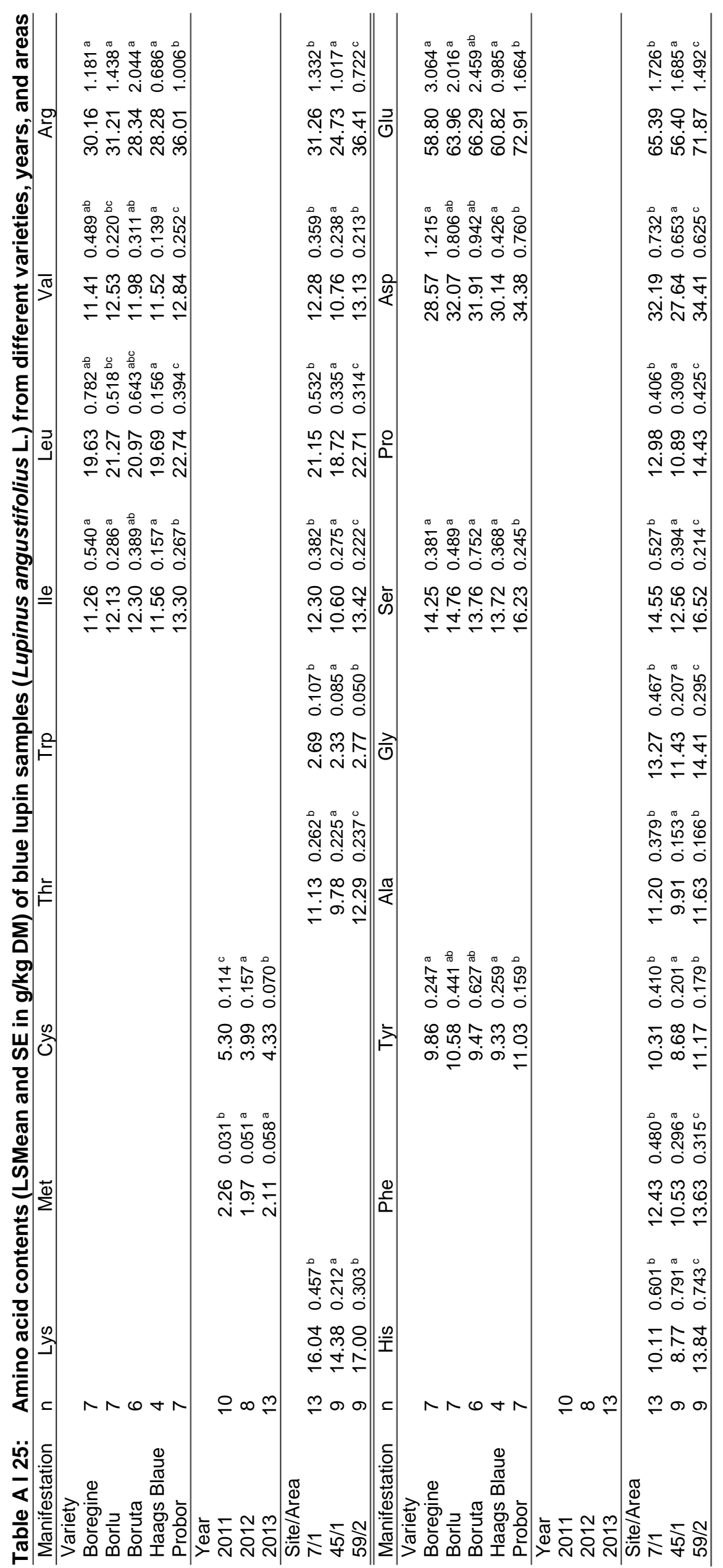




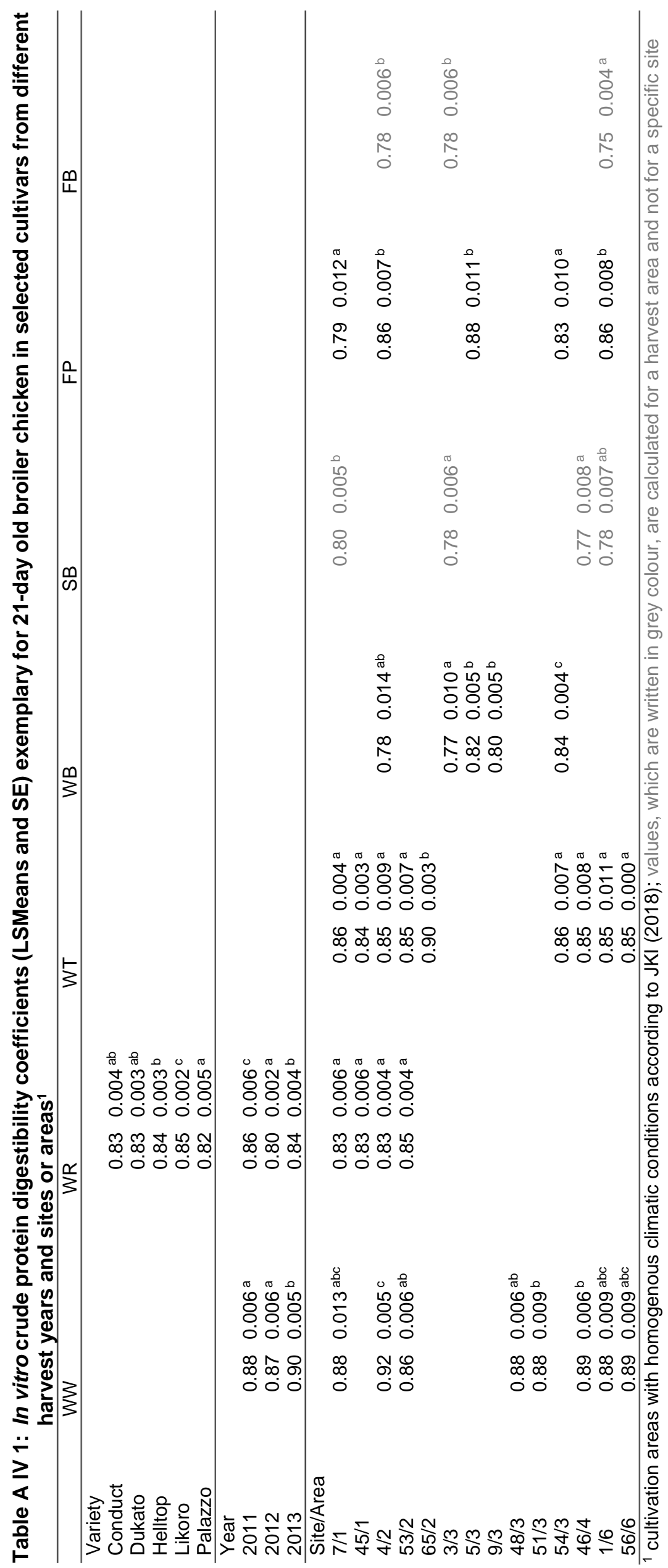


Table A V 1: Contents of thiamine and riboflavin in selected cereals and grain legumes [mg/kg DM]

\begin{tabular}{|c|c|c|c|}
\hline & Variety & Thiamine & Riboflavin \\
\hline \multicolumn{4}{|l|}{ Cereals } \\
\hline Spring triticale & Dublet & 2.05 & 0.98 \\
\hline Triticosecale & Kulula & 2.01 & 0.94 \\
\hline & Nagano & 1.90 & 0.86 \\
\hline Naked barley & Nora & 1.90 & 1.03 \\
\hline Hordeum vulgare L., var nudum & & & \\
\hline $\begin{array}{l}\text { Naked oats } \\
\text { Avena sativa L., var nuda }\end{array}$ & Nihao & 3.51 & 1.58 \\
\hline \multicolumn{4}{|l|}{ Legumes } \\
\hline $\begin{array}{l}\text { Winter field pea } \\
\text { Pisum sativum } \mathrm{L} \text {. }\end{array}$ & James & 6.23 & 1.64 \\
\hline $\begin{array}{l}\text { Winter field bean } \\
\text { Vicia faba } \mathrm{L} \text {. }\end{array}$ & Hiverna & & 2.42 \\
\hline Yellow lupin & Mister ( $\mathrm{n}=2)$ & $6.67 / 7.76$ & $2.55 / 2.70$ \\
\hline Lupinus luteus $\mathrm{L}$. & Taper $(n=2)$ & $6.21 / 6.97$ & $2.68 / 2.76$ \\
\hline
\end{tabular}

Table A V 2: Maximum differences of thiamine and riboflavin contents between factor manifestations of cereals and grain legumes $[\mathrm{mg} / \mathrm{kg} \mathrm{DM}]-$ absolute as well as relative to mean content

\begin{tabular}{|c|c|c|c|c|c|c|c|}
\hline & \multirow[b]{2}{*}{$\mathrm{n}$} & \multicolumn{3}{|c|}{ Thiamine } & \multicolumn{3}{|c|}{ Riboflavin } \\
\hline & & variety & year & site/area & variety & year & site/area \\
\hline \multicolumn{8}{|l|}{ Cereals } \\
\hline $\begin{array}{l}\text { Winter wheat } \\
\text { Triticum aestivum L. }\end{array}$ & 70 & $\begin{array}{l}0.38 \\
16.5 \%\end{array}$ & $\begin{array}{l}0.18 \\
7.8 \%\end{array}$ & $\begin{array}{c}0.23 \\
10.0 \%\end{array}$ & $\begin{array}{l}0.04 \\
5.4 \%\end{array}$ & $\begin{array}{l}0.06 \\
8.1 \%\end{array}$ & - \\
\hline $\begin{array}{l}\text { Spring wheat } \\
\text { Triticum aestivum L. }\end{array}$ & 25 & $\begin{array}{c}0.43 \\
19.4 \%\end{array}$ & $\begin{array}{l}0.22 \\
9.9 \%\end{array}$ & - & $\begin{array}{c}0.21 \\
24.7 \%\end{array}$ & $\begin{array}{c}0.16 \\
18.8 \%\end{array}$ & - \\
\hline $\begin{array}{l}\text { Winter rye } \\
\text { Secale cereale } \mathrm{L} \text {. }\end{array}$ & 81 & $\begin{array}{c}0.42 \\
23.9 \%\end{array}$ & $\begin{array}{c}0.23 \\
13.1 \%\end{array}$ & $\begin{array}{c}0.46 \\
26.1 \%\end{array}$ & $\begin{array}{l}0.06 \\
5.7 \%\end{array}$ & $\begin{array}{c}0.17 \\
16.0 \%\end{array}$ & $\begin{array}{l}0.09 \\
8.5 \%\end{array}$ \\
\hline $\begin{array}{l}\text { Winter triticale } \\
\text { Triticosecale }\end{array}$ & 92 & $\begin{array}{c}0.24 \\
13.1 \%\end{array}$ & - & $\begin{array}{c}0.28 \\
15.3 \%\end{array}$ & $\begin{array}{c}0.12 \\
13.2 \%\end{array}$ & $\begin{array}{c}0.11 \\
12.1 \%\end{array}$ & $\begin{array}{c}0.12 \\
13.2 \%\end{array}$ \\
\hline $\begin{array}{l}\text { Winter barley } \\
\text { Hordeum vulgare L. }\end{array}$ & 15 & - & - & $\begin{array}{c}0.74 \\
33.5 \%\end{array}$ & - & - & $\begin{array}{l}0.27 \\
33.8 \%\end{array}$ \\
\hline $\begin{array}{l}\text { Spring barley } \\
\text { Hordeum vulgare L. }\end{array}$ & 47 & - & $\begin{array}{c}0.54 \\
26.3 \%\end{array}$ & - & $\begin{array}{l}0.08 \\
8.5 \%\end{array}$ & $\begin{array}{c}0.12 \\
12.8 \%\end{array}$ & $\begin{array}{c}0.10 \\
10.6 \%\end{array}$ \\
\hline $\begin{array}{l}\text { Oats } \\
\text { Avena sativa L. }\end{array}$ & 80 & $\begin{array}{c}0.35 \\
12.9 \%\end{array}$ & $\begin{array}{c}0.44 \\
16.2 \%\end{array}$ & $\begin{array}{c}0.47 \\
17.3 \%\end{array}$ & - & $\begin{array}{c}0.14 \\
14.0 \%\end{array}$ & $\begin{array}{c}0.25 \\
25.0 \%\end{array}$ \\
\hline \multicolumn{8}{|l|}{ Grain legumes } \\
\hline $\begin{array}{l}\text { Spring field pea } \\
\text { Pisum sativum } \mathrm{L} .\end{array}$ & 41 & - & $\begin{array}{c}1.68 \\
28.9 \%\end{array}$ & $\begin{array}{c}1.97 \\
33.9 \%\end{array}$ & $\begin{array}{l}0.14 \\
8.1 \%\end{array}$ & $\begin{array}{c}0.51 \\
29.5 \%\end{array}$ & $\begin{array}{c}0.18 \\
10.1 \%\end{array}$ \\
\hline $\begin{array}{l}\text { Spring field bean } \\
\text { Vicia faba } \mathrm{L} \text {. }\end{array}$ & $57 / 59^{*}$ & $\begin{array}{c}1.25 \\
25.2 \%\end{array}$ & $\begin{array}{c}2.30 \\
46.3 \%\end{array}$ & $\begin{array}{c}0.94 \\
18.9 \%\end{array}$ & $\begin{array}{c}0.94 \\
34.2 \%\end{array}$ & - & $\begin{array}{l}0.15 \\
5.3 \%\end{array}$ \\
\hline $\begin{array}{l}\text { Blue lupin } \\
\text { Lupinus angustifolius L. }\end{array}$ & 31 & - & - & $\begin{array}{c}1.90 \\
38.7 \%\end{array}$ & - & $\begin{array}{l}0.16 \\
6.7 \%\end{array}$ & $\begin{array}{c}0.31 \\
13.0 \%\end{array}$ \\
\hline
\end{tabular}


Table A V 3: Thiamine and riboflavin contents (LSMean and SE) of winter wheat samples (Triticum aestivum L.) from different varieties, harvest years, and harvest areas in $\mathbf{~} \mathrm{g} / \mathbf{k g} \mathrm{DM}$

\begin{tabular}{|c|c|c|c|c|c|c|c|}
\hline \multirow{2}{*}{$\begin{array}{l}\text { Manifestation } \\
\text { Variety }\end{array}$} & \multirow[t]{2}{*}{$\mathrm{n}$} & \multicolumn{3}{|c|}{ Thiamine } & \multicolumn{3}{|c|}{ Riboflavin } \\
\hline & & & & & & & \\
\hline Butaro & 24 & 2.45 & 0.036 & b & 0.76 & 0.007 & $\mathrm{~b}$ \\
\hline Capo & 26 & 2.07 & 0.036 & a & 0.77 & 0.010 & $\mathrm{~b}$ \\
\hline Naturastar & 20 & 2.38 & 0.042 & b & 0.73 & 0.011 & a \\
\hline Year & & & & & & & \\
\hline 2011 & 16 & 2.28 & 0.042 & $a b$ & 0.76 & 0.017 & $a b$ \\
\hline 2012 & 22 & 2.40 & 0.053 & b & 0.72 & 0.010 & a \\
\hline 2013 & 32 & 2.22 & 0.052 & a & 0.78 & 0.013 & b \\
\hline Area $^{1}$ & & & & & & & \\
\hline 1 & 8 & 2.20 & 0.080 & $a b$ & & & \\
\hline 2 & 17 & 2.21 & 0.033 & a & & & \\
\hline 3 & 23 & 2.43 & 0.058 & b & & & \\
\hline 4 & 10 & 2.32 & 0.063 & $a b$ & & & \\
\hline 6 & 12 & 2.37 & 0.075 & $a b$ & & & \\
\hline
\end{tabular}

${ }^{1} \mathrm{JKI}$ (2018); superscript letters mark significant differences in columns with $\mathrm{P}<0.05$

Table A V 4: Thiamine and riboflavin contents (LSMean and SE) of spring wheat samples (Triticum aestivum L.) from different varieties, harvest years, and harvest areas in $\mathbf{~} \mathrm{g} / \mathrm{kg}$ DM

\begin{tabular}{lccccccc}
\hline Manifestation & $\mathrm{n}$ & \multicolumn{3}{c}{ Thiamine } & \multicolumn{3}{c}{ Riboflavin } \\
\hline Variety & & & & & & \\
Eminent & 8 & 2.10 & 0.098 & $\mathrm{a}$ & 0.82 & 0.027 & $\mathrm{a}$ \\
Granny & 4 & 2.29 & 0.151 & $\mathrm{ab}$ & 1.03 & 0.043 & $\mathrm{~b}$ \\
KWS Chamsin & 4 & 2.53 & 0.162 & $\mathrm{ab}$ & 0.83 & 0.032 & $\mathrm{a}$ \\
KWS Scirocco & 9 & 2.42 & 0.072 & $\mathrm{~b}$ & 0.84 & 0.021 & $\mathrm{a}$ \\
\hline Year & & & & & 0.88 & 0.031 & $\mathrm{ab}$ \\
2011 & 8 & 2.13 & 0.124 & 0.96 & 0.024 & $\mathrm{~b}$ \\
2012 & 8 & 2.42 & 0.085 & 0.80 & 0.025 & $\mathrm{a}$ \\
2013 & 9 & 2.45 & 0.101 & & & \\
\hline Area & & & & & & & \\
1 & 5 & & & & & & \\
2 & 12 & 8 & & & & &
\end{tabular}

Table A V 5: Thiamine and riboflavin contents (LSMean and SE) of winter rye samples (Secale cereale L.) from different varieties, harvest years, and harvest sites in $\mathrm{mg} / \mathrm{kg} \mathrm{DM}$

\begin{tabular}{lccccccc}
\hline Manifestation & $\mathrm{n}$ & \multicolumn{3}{c}{ Thiamine } & \multicolumn{3}{c}{ Riboflavin } \\
\hline Variety & & & & & & & \\
Conduct & 18 & 1.80 & 0.043 & $\mathrm{~b}$ & 1.07 & 0.011 & $\mathrm{abc}$ \\
Dukato & 18 & 1.76 & 0.041 & $\mathrm{~b}$ & 1.08 & 0.015 & $\mathrm{abc}$ \\
Helltop & 17 & 1.99 & 0.055 & $\mathrm{c}$ & 1.04 & 0.013 & $\mathrm{ab}$ \\
Likoro & 10 & 1.76 & 0.057 & $\mathrm{~b}$ & 1.09 & 0.015 & $\mathrm{c}$ \\
Palazzo & 18 & 1.57 & 0.060 & $\mathrm{a}$ & 1.03 & 0.011 & $\mathrm{a}$ \\
\hline Year & & & & & & & \\
2011 & 16 & 1.66 & 0.089 & $\mathrm{a}$ & 1.14 & 0.025 & $\mathrm{c}$ \\
2012 & 33 & 1.77 & 0.039 & $\mathrm{a}$ & 0.97 & 0.013 & $\mathrm{a}$ \\
2013 & 32 & 1.89 & 0.029 & $\mathrm{~b}$ & 1.08 & 0.010 & $\mathrm{~b}$ \\
\hline Site/Area & & & & & & & \\
$7 / 1$ & 14 & 1.71 & 0.064 & $\mathrm{ab}$ & 1.07 & 0.027 & $\mathrm{ab}$ \\
$45 / 1$ & 14 & 1.53 & 0.035 & $\mathrm{a}$ & 1.03 & 0.006 & $\mathrm{a}$ \\
$4 / 2$ & 13 & 1.99 & 0.035 & $\mathrm{c}$ & 1.11 & 0.015 & $\mathrm{~b}$ \\
$53 / 2$ & 10 & 1.77 & 0.055 & $\mathrm{bc}$ & 1.08 & 0.018 & $\mathrm{~b}$ \\
$5 / 3$ & 10 & 1.80 & 0.039 & $\mathrm{~b}$ & 1.02 & 0.013 & $\mathrm{a}$ \\
$46 / 4$ & 7 & 1.95 & 0.035 & $\mathrm{c}$ & 1.08 & 0.013 & $\mathrm{~b}$ \\
$1 / 6$ & 13 & 1.70 & 0.087 & $\mathrm{abc}$ & 1.05 & 0.023 & $\mathrm{ab}$ \\
\hline
\end{tabular}

thiamine: intervals are back-transformed; ${ }^{1} \mathrm{JKI}(2018)$; superscript letters mark significant differences in columns with $\mathrm{P}<0.05$ 
Table A V 6: Thiamine and riboflavin contents (LSMean and SE) of winter triticale samples (Triticosecale) from different varieties, harvest years, and harvest areas in $\mathrm{mg} / \mathrm{kg} \mathrm{DM}$

\begin{tabular}{|c|c|c|c|c|c|c|c|}
\hline \multirow{2}{*}{$\begin{array}{l}\text { Manifestation } \\
\text { Variety }\end{array}$} & \multirow[t]{2}{*}{$\mathrm{n}$} & \multicolumn{3}{|c|}{ Thiamine } & \multicolumn{3}{|c|}{ Riboflavin } \\
\hline & & & & & & & \\
\hline Benetto & 21 & 1.92 & 0.043 & $\mathrm{bc}$ & 0.96 & 0.020 & bc \\
\hline Cosinus & 19 & 1.75 & 0.050 & a & 0.88 & 0.015 & a \\
\hline Moderato & 8 & 1.84 & 0.070 & $a b c$ & 0.92 & 0.021 & $a b$ \\
\hline Sequenz & 18 & 1.99 & 0.038 & c & 0.90 & 0.014 & $a b$ \\
\hline Tarzan & 9 & 1.89 & 0.062 & $a b c$ & 1.00 & 0.027 & c \\
\hline Tulus & 17 & 1.86 & 0.018 & $\mathrm{ab}$ & 0.88 & 0.022 & $a b$ \\
\hline \multicolumn{8}{|l|}{ Year } \\
\hline 2011 & 23 & & & & 0.99 & 0.017 & \\
\hline 2012 & 35 & & & & 0.88 & 0.018 & \\
\hline 2013 & 34 & & & & 0.91 & 0.014 & \\
\hline \multicolumn{8}{|l|}{ Area $^{1}$} \\
\hline 1 & 32 & 1.72 & 0.046 & a & 0.87 & 0.020 & a \\
\hline 2 & 24 & 1.96 & 0.049 & $\mathrm{~b}$ & 0.98 & 0.016 & $\mathrm{~b}$ \\
\hline 3 & 15 & 2.00 & 0.054 & $\mathrm{~b}$ & 0.94 & 0.026 & $a b$ \\
\hline 4 & 10 & 1.84 & 0.105 & $\mathrm{ab}$ & 0.94 & 0.027 & $a b$ \\
\hline 6 & 11 & 1.86 & 0.068 & $\mathrm{ab}$ & 0.89 & 0.024 & $a b$ \\
\hline
\end{tabular}

riboflavin: intervals are back-transformed; ${ }^{1} \mathrm{JKI}$ (2018); superscript letters mark significant differences in columns with $\mathrm{P}<0.05$

Table A V 7: Thiamine and riboflavin contents (LSMean and SE) of winter barley samples (Hordeum vulgare L.) from different harvest sites in $\mathrm{mg} / \mathrm{kg} \mathrm{DM}$

\begin{tabular}{|c|c|c|c|c|c|c|c|c|}
\hline Site/Area ${ }^{1}$ & Year & $\mathrm{n}$ & \multicolumn{3}{|c|}{ Thiamine } & \multicolumn{3}{|c|}{ Riboflavin } \\
\hline $4 / 2$ & 2012 & 3 & 2.31 & 0.062 & $\mathrm{~b}$ & 0.72 & 0.019 & $a$ \\
\hline $9 / 3$ & 2012 & 3 & 2.05 & 0.052 & a & 0.70 & 0.033 & a \\
\hline $3 / 3$ & 2013 & 3 & 2.23 & 0.023 & $\mathrm{~b}$ & 0.97 & 0.044 & $\mathrm{~b}$ \\
\hline $5 / 3$ & 2013 & 3 & 1.99 & 0.045 & a & 0.90 & 0.009 & b \\
\hline $54 / 3$ & 2013 & 3 & 2.73 & 0.060 & c & 0.92 & 0.014 & $\mathrm{~b}$ \\
\hline
\end{tabular}

$1 \mathrm{JKI}(2018)$; superscript letters mark significant differences in columns with $\mathrm{P}<0.05$

Table A V 8: Thiamine and riboflavin contents (LSMean and SE) of spring barley samples (Hordeum vulgare L.) from different varieties, harvest years, and harvest areas in $\mathrm{mg} / \mathrm{kg} \mathrm{DM}$

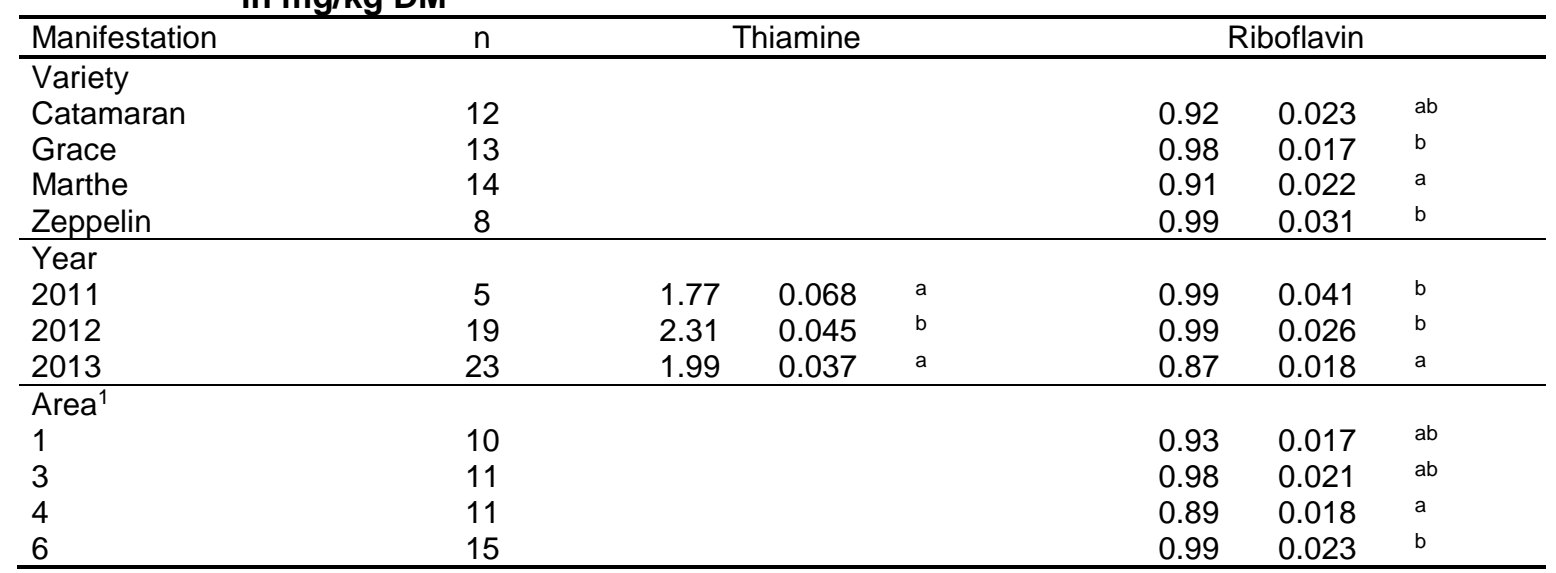

$1 \mathrm{JKI}$ (2018); superscript letters mark significant differences in columns with $\mathrm{P}<0.05$ 
Table A V 9: Thiamine and riboflavin contents (LSMean and SE) of oat samples (Avena sativa L.) from different varieties, harvest years, and harvest sites in $\mathrm{mg} / \mathrm{kg} \mathrm{DM}$

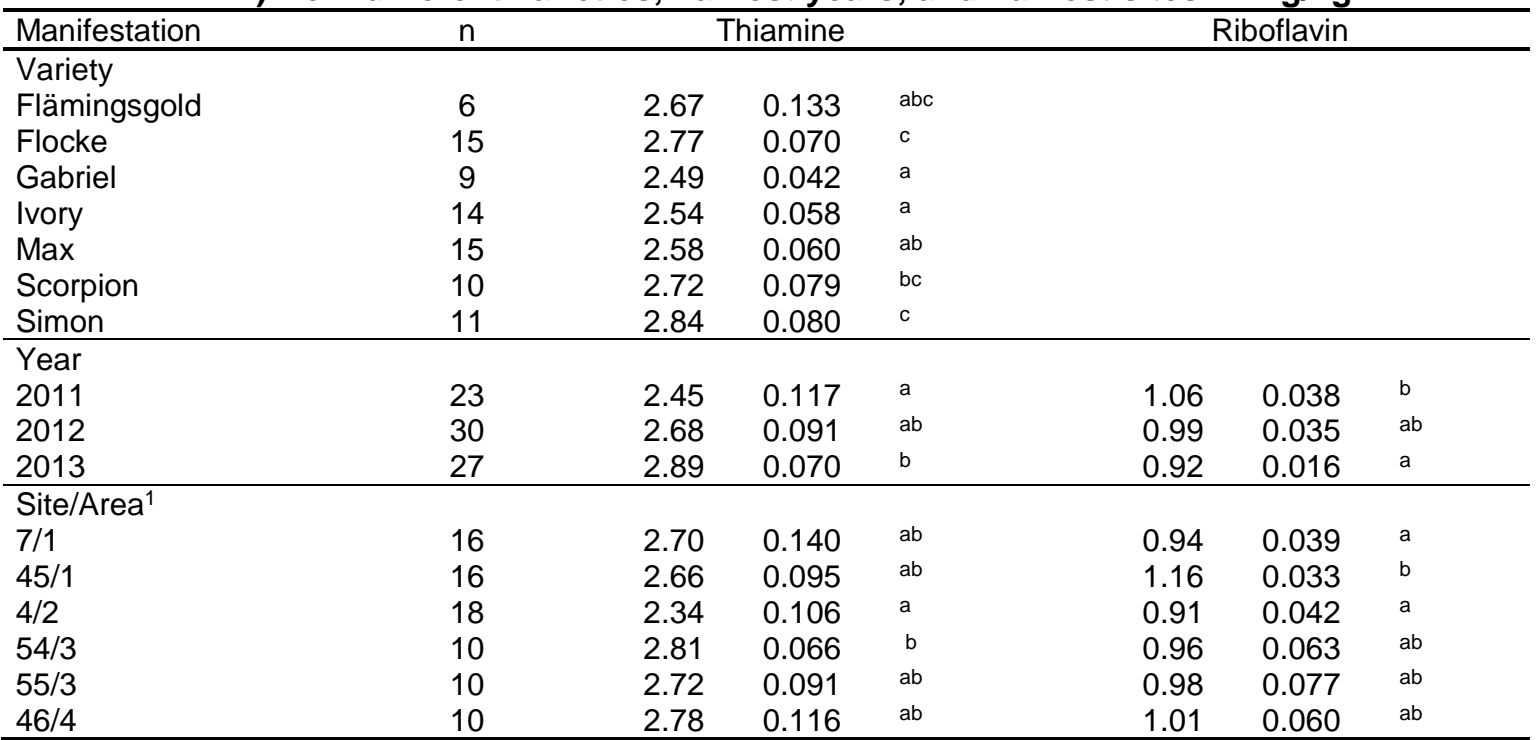

thiamine, riboflavin: Intervals are back-transformed; ${ }^{1} \mathrm{JKI}$ (2018); superscript letters mark significant differences in columns with $\mathrm{P}<0.05$

Table A V 10: Thiamine and riboflavin contents (LSMean and SE) of field pea samples (Pisum sativum L.) from different varieties, harvest years, and harvest sites in $\mathrm{mg} / \mathrm{kg}$ DM

\begin{tabular}{|c|c|c|c|c|c|c|c|}
\hline \multirow{2}{*}{$\begin{array}{l}\text { Manifestation } \\
\text { Variety }\end{array}$} & \multirow[t]{2}{*}{$\mathrm{n}$} & \multicolumn{3}{|c|}{ Thiamine } & \multicolumn{3}{|c|}{ Riboflavin } \\
\hline & & & & & & & \\
\hline Alvesta & 9 & & & & 1.78 & 0.035 & bcd \\
\hline Auckland & 6 & & & & 1.67 & 0.020 & a \\
\hline Casablanca & 5 & & & & 1.65 & 0.050 & $a b c$ \\
\hline KWS La Manscha & 5 & & & & 1.75 & 0.022 & $\mathrm{~cd}$ \\
\hline Navarro & 8 & & & & 1.66 & 0.032 & $a b$ \\
\hline Salamanca & 8 & & & & 1.80 & 0.029 & d \\
\hline \multicolumn{8}{|l|}{ Year } \\
\hline 2011 & 12 & 4.53 & 0.231 & a & 1.57 & 0.021 & a \\
\hline 2012 & 12 & 6.02 & 0.335 & $\mathrm{~b}$ & 2.05 & 0.043 & b \\
\hline 2013 & 17 & 6.21 & 0.221 & $\mathrm{~b}$ & 1.54 & 0.027 & $\mathrm{a}$ \\
\hline \multicolumn{8}{|l|}{ Site/Area ${ }^{1}$} \\
\hline $7 / 1$ & 9 & 4.54 & 0.187 & a & 1.79 & 0.024 & c \\
\hline $4 / 2$ & 16 & 6.51 & 0.220 & c & 1.78 & 0.033 & $\mathrm{bc}$ \\
\hline $5 / 3$ & 8 & 5.61 & 0.223 & b & 1.69 & 0.034 & $a b$ \\
\hline $54 / 3$ & 8 & 5.69 & 0.490 & $a b c$ & 1.61 & 0.032 & a \\
\hline
\end{tabular}

${ }_{1} \mathrm{JKI}$ (2018); superscript letters mark significant differences in columns with $\mathrm{P}<0.05$ 
Table A V 11: Thiamine and riboflavin contents (LSMean and SE) of field bean samples (Vicia faba L.) from different varieties, harvest years, and harvest areas in $\mathrm{mg} / \mathrm{kg} \mathrm{DM}$

\begin{tabular}{|c|c|c|c|c|c|c|c|}
\hline \multirow{2}{*}{$\frac{\text { Manifestation }}{\text { Variety }}$} & \multirow[t]{2}{*}{$\mathrm{n}$} & \multicolumn{3}{|c|}{ Thiamine } & \multicolumn{3}{|c|}{ Riboflavin } \\
\hline & & \multirow[b]{2}{*}{4.34} & \multirow[b]{2}{*}{0.189} & \multirow[b]{2}{*}{$a b$} & \multirow[b]{2}{*}{3.29} & \multirow[b]{2}{*}{0.082} & \multirow[b]{2}{*}{$d$} \\
\hline Alexia & 7 & & & & & & \\
\hline Bioro & 9 & 4.54 & 0.104 & bc & 2.77 & 0.048 & $\mathrm{bc}$ \\
\hline Divine & 9 & 5.14 & 0.163 & $d$ & 2.35 & 0.062 & a \\
\hline Fuego & 13 & 3.87 & 0.145 & a & 2.83 & 0.028 & c \\
\hline Isabell & 13 & 4.69 & 0.158 & bc & 2.46 & 0.029 & a \\
\hline \multicolumn{8}{|l|}{ Year } \\
\hline 2012 & 22 & 3.55 & 0.179 & a & & & \\
\hline 2013 & 37 & 5.85 & 0.098 & $\mathrm{~b}$ & & & \\
\hline \multicolumn{8}{|l|}{ Area $^{1}$} \\
\hline 2 & 12 & 4.16 & 0.074 & a & 2.56 & 0.055 & a \\
\hline
\end{tabular}

all intervals are back-transformed; ${ }^{1} \mathrm{JKI}$ (2018); superscript letters mark significant differences in columns with $\mathrm{P}<0.05$

Table A V 12: Thiamine and riboflavin contents (LSMean and SE) of blue lupin samples (Lupinus angustifolius L.) from different varieties, harvest years, and harvest areas in $\mathrm{mg} / \mathbf{k g ~ D M}$

\begin{tabular}{|c|c|c|c|c|c|c|c|}
\hline \multirow{2}{*}{$\begin{array}{l}\text { Manifestation } \\
\text { Variety }\end{array}$} & $\mathrm{n}$ & \multicolumn{3}{|c|}{ Thiamine } & \multicolumn{3}{|c|}{ Riboflavin } \\
\hline & & & & & & & \\
\hline Boregine & 7 & & & & & & \\
\hline Borlu & 7 & & & & & & \\
\hline Boruta & 6 & & & & & & \\
\hline Haags Blaue & 4 & & & & & & \\
\hline Probor & 7 & & & & & & \\
\hline Year & & & & & & & \\
\hline 2011 & 10 & & & & 2.28 & 0.045 & $\mathrm{ab}$ \\
\hline 2012 & 8 & & & & 2.21 & 0.060 & a \\
\hline 2013 & 13 & & & & 2.37 & 0.021 & $\mathrm{~b}$ \\
\hline Site/Area ${ }^{1}$ & & & & & & & \\
\hline $7 / 1$ & 13 & 4.12 & 0.210 & a & 2.20 & 0.040 & a \\
\hline $45 / 1$ & 9 & 3.67 & 0.150 & $a$ & 2.18 & 0.033 & $a$ \\
\hline $59 / 2$ & 9 & 5.57 & 0.365 & b & 2.49 & 0.076 & $\mathrm{~b}$ \\
\hline
\end{tabular}

$1 \mathrm{JKI}$ (2018); superscript letters mark significant differences in columns with $\mathrm{P}<0.05$ 


\section{Declaration of Academic Integrity}

I hereby confirm that the present thesis is solely my own work and that if any text passages or diagrams from books, papers, the Web or other sources have been copied or in any other way used, all references - including those found in electronic media - have been acknowledged and fully cited. 


\section{Danksagung/Acknowledgement}

Sehr herzlich möchte ich mich bei Prof. Dr. Frank Liebert für die Betreuung aus der Ferne bedanken.

Dr. Karen Aulrich bin ich für ihre Betreuung vor Ort und im Labor sehr dankbar.

Die Unterstützung mit ihrem Wissen, konstruktiver Kritik und wissenschaftlichen Ratschlägen war mir eine große Hilfe.

Zudem danke ich Prof. Dr. Elke Pawelzik für Ihren Einsatz als Gutachterin.

Weiterhin bin ich Dr. Herwart Böhm, Volker Michel, Andrea Zipp und dem Paper Writing Club dankbar für statistische und methodische Unterstützung.

Mein herzlicher Dank gebührt auch dem Trenthorster Laborteam Jörg Bokemeyer, Gudrun Dählk, Monika Felsch, Christian Gißel, Rainer Legrand, Lore Mattiesch, Helga Neumann, Anja Przyborowski und Birgit Thaler.

Bei den Landwirtschaftskammern und Versuchsanstalten bedanke ich mich für die Bereitstellung der Proben aus den Sortenversuchen.

Herrn Prof. Dr. Michael Grashorn und seinem Team sowie Frau Dr. Carolin Ritteser danke ich für die Zusammenarbeit bei den Verdaulichkeitsuntersuchungen und die Bereitstellung der Rückstellproben für die Validierung der in vitro-Methode.

Ein ganz besonderer Dank ist auch an meine Familie und meine Freunde gerichtet, die mir geduldig den Rücken stärken.

Dem gesamten Trenthorster Team gilt mein Dank für die interessanten, fachlichen oder vom Ernst des Lebens ablenkenden Gespräche und all das Drumherum. 